\title{
6. SITE 386: FRACTURE VALLEY SEDIMENTATION ON THE CENTRAL BERMUDA RISE
}

\author{
The Shipboard Scientific Party ${ }^{1}$
}

\section{SITE DATA}

Position: $31^{\circ} 11.21^{\prime} \mathrm{N}, 64^{\circ} 14.94^{\prime} \mathrm{W}$

Water Depth (PDR, sea level): 4782 meters

Water Depth (PDR, rig floor): 4792 meters

Bottom Felt at (rig floor): 4793 meters

Penetration: 973.8 meters

Number of Holes: 1

Number of Cores: 66

Total Length Cored: 626.70 meters

Total Core Recovered: 438.15 meters

Core Recovery: 69.9 per cent

Oldest Sediment Cored: Black claystone Bottoms at: 964.2 meters

Age: Early Albian

Velocity: $1.94-2.46 \mathrm{~km} / \mathrm{sec}$

Nature of Basement: Basalt

Encountered at: 964.2 meters

Velocity: $3.90-4.45 \mathrm{~km} / \mathrm{sec}$

Date Occupied: $2202 \mathrm{Z}$ hours, 24 July 1975

Date Departed: $2010 \mathrm{Z}$ hours, 31 July 1975

Time on Site: 6 days, 22 hours, 8 minutes

Principal Results: Site 386 was drilled to a depth of 973.8 meters on the central Bermuda Rise, $140 \mathrm{~km}$ southsoutheast of Bermuda. Sixty-six cores were taken, of which the lowest recovered 1.90 meters of altered basalt. Basement age was established as early Albian on the basis of nannoplankton in the overlying green/black claystones. The section consists of discontinuously cored lower Pleistocene marly nannofossil ooze and brown clay $(0$ to $\sim 62 \mathrm{~m})$

'Brian E. Tucholke (Co-Chief Scientist), Lamont-Doherty Geological Observatory, Palisades, New York; Peter R. Vogt (Co-Chief Scientist), Naval Research Laboratory, Washington, D. C.; Kenneth R. Demars, University of Rhode Island, Kingston, Rhode Island (now at: University of Delaware, Newark, Delaware); Jon S. Galehouse, San Francisco State University, San Francisco, California; Robert L. Houghton, Woods Hole Oceanographic Institution, Woods Hole, Massachusetts (now at: University of Alberta, Edmonton, Alberta, Canada); Ansis Kaneps, Deep Sea Drilling Project, Scripps Institution of Oceanography, La Jolla, California; John W. Kendrick, Shell Development Company, Houston, Texas; I. N. McCave, University of East Anglia, Norwich, England; Charles L. McNulty, University of Texas, Arlington, Texas; Ivar O. Murdmaa, P. P. Shirshov Institute of Oceanology, Moscow, USSR; Hisatake Okada, Lamont-Doherty Geological Observatory, Palisades, New York (now at: Yamagata University, Yamagata, Japan); and Peter Rothe, Mineralogisch Petrografisches Institut der Universitat Heidelberg, Heidelberg, Federal Republic of Germany (now at: Geographisches Institut der Universitat Mannheim, Mannheim, Federal Republic of Germany). overlying upper to middle Miocene quartzose clays and nannofossil ooze (62-148 m); continuously cored lower Miocene calcareous turbidites grading downward into Oligocene and upper Eocene volcaniclastic turbidites $(148-328 \mathrm{~m})$; middle Eocene siliceous $(328-408 \mathrm{~m})$ and calcareous (408-490 m) cyclicly deposited turbidites, overlying middle to lower Eocene cherty and radiolarian mudstones (490-613 m); upper Maestrichtian to upper Cenomanian multicolored claystone with subsidiary marly limestone (613-724 m) above upper Cenomanian to lower Albian black and green claystones (724-964 m); and basalt

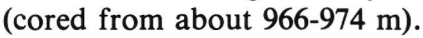

Deposition was predominately continuous although highly variable in rate. High rates characterize the sapropelic claystones $(\sim 16 \mathrm{~m} / \mathrm{m} . \mathrm{y}$.$) , middle Eocene cal-$ careous-siliceous turbidites $(20-40 \mathrm{~m} / \mathrm{m} . \mathrm{y}$.$) , late Paleo-$ cene to early Eocene radiolarian mudstones $(\sim 20 \mathrm{~m} / \mathrm{m}$.y. $)$, and volcaniclastic turbidites $(9 \mathrm{~m} / \mathrm{m} . \mathrm{y}$.).

Volcaniclastic turbidites with shallow water detritus indicate the Bermuda volcanoes were emergent by middle to late Eocene time $(\sim 43 \mathrm{~m} . \mathrm{y}$.) and had been leveled by erosion by late Oligocene time. The upward transition from calcareous/siliceous turbidites, possibly derived from as far away as the continental margin of North America, to volcaniclastic turbidites is attributed to formation of the Bermuda Rise by epeirogenic uplift, coincident with or immediately followed by volcanic activity at Bermuda in the center of the rise. A 28-meter section of upper Cenomanian zeolitic multicolored claystone containing glass shards suggests earlier volcanic activity at $92-96 \mathrm{~m} . \mathrm{y}$. If Bermuda already existed at 90-110 m.y.B.P. as proposed by Reynolds and Aumento, these volcanogenic components also may have a Bermudan origin.

Organic carbon analyses in the sapropelic claystones show carbon maxima in the mid-late Cenomanian (up to $11.5 \%$ ) and early Albian (4\%); this double-peaked character possibly correlates with similar carbon distribution in the black clays of Site 105. Organic carbon content varies independently of sediment blackness (reducing conditions), suggesting independent cycles of productivity and bottom water oxygenation.

Horizon $A^{v}$ correlates with the top of the upper Eoceneupper Oligocene volcaniclastic turbidites, and is seismically continuous with the Bermuda Pedestal. The next deeper reflector (Horizon $A^{c}$ ) correlates with the top of an 82-meter-thick sequence of middle Eocene calcareous turbidites, which overlie and seismically mask the lower to middle Eocene cherty sediments. Horizon $A^{*}$ corresponds to a middle to upper Maestrichtian limestone/chalk facies near the top of the Upper Cretaceous multicolored clays.

The early Albian age of sediments immediately above basement suggests that crust forming the east flank of the Bermuda Rise was generated at the relatively rapid rate of about $2.4 \mathrm{~cm} / \mathrm{yr}$. Several brief intervals of reversed polarity were found in Albian sediments, post-dating the Keathley (M) sequence. 


\section{BACKGROUND AND OBJECTIVES}

\section{General Review}

Shortly after the advent of continuous seismic profiling in the deep sea (Ewing and Tirey, 1961), profiler records obtained in the western North Atlantic allowed definition of certain distinctive acoustic reflectors which appeared to be widespread within the basin. These reflectors represent interfaces between media of dissimilar acoustic impedance and therefore are presumably of dissimilar lithofacies. The most distinctive and easily observed of these reflectors was called Horizon $A$, and in the early records it appeared as a reflector or series of reflectors bounded above and below by acoustically non-laminated to weakly laminated sediments.

As more profiler data were accumulated, Horizon $A$ was traced to an outcrop area north of San Salvador in the deep western North Atlantic basin. Piston cores taken there recovered Maestrichtian turbidites, which were thought to date Horizon $A$ as Upper Cretaceous and confirm an earlier hypothesis that Horizon $A$ represents a buried abyssal plain (Ewing et al., 1966).

In the early phase of the Deep Sea Drilling Project (Legs 1, 2, 4, and 11), the Horizon $A$ reflector sequence was targeted at several drill sites. Porcelanitic chert dated as lower to middle Eocene was encountered near the level of Horizon $A$ at Sites 6 through 10, locally in association with fine-grained turbidites. These findings led Ewing et al. (1970) to speculate that Horizon $A$ was both a chronostratigraphic and a lithostratigraphic unit composed of "middle Eocene" cherts. However, later drilling results (Leg 11) clouded this simplistic picture when a 60-90 m.y. hiatus (Cretaceous to Neogene) was encountered at Sites 101 and 105 at the level of Horizon $A$ (Hollister, Ewing, et al., 1972). A further complication is apparent north of Puerto Rico at Site 28, where Horizon $A$ represents silicified sediments at the top of a series of Eocene turbidites underlying upper Paleogene to Neogene current-deposited clays (Bader et al., 1970; Tucholke and Ewing, 1974).

These departures from the general assumption that Horizon $A$ represents Eocene cherts pointed out the need for detailed study of the acoustic character, chronostratigraphic relationships, and lithostratigraphy of the horizon, especially because Horizon $A$ is a prominent marker in sediments of the North American basin and is widely used for geologic interpretations of various aspects of North Atlantic sedimentation history.

Recent detailed study of the acoustic character and distribution of Horizon $A$ has shown that what has been simplistically called "Horizon $A$ " is actually a complex and laterally variable series of reflectors, each of which may define a specific set of paleoceanographic and paleosedimentation conditions (Tucholke, this volume). Over much of the central and western Bermuda Rise, "Horizon $A$ " appears as a pair of reflectors or sometimes as a complex series of reflectors. Where "Horizon $A$ "' is dual, the reflectors are 0.1 to 0.2 seconds apart, and the deeper reflector is usually much stronger. It is this deeper reflector that previously was correlated with "Horizon $A$ " chert.
This pair of reflectors commonly merges into a single reflector west of the Bermuda Rise, and in the locations where this single "Horizon $A$ " was drilled (Sites 101, $105)$, the reflector correlates with a major unconformity (Ewing and Hollister, 1972).

On the central Bermuda Rise, the reflector pair comprising "Horizon $A$ " is masked by an overlying, highly reflective horizon which merges with the acoustically opaque Bermuda Pedestal; this reflector was thought to be intimately linked with the volcanic development of Bermuda. None of the reflectors immediately above "Horizon $A$ chert" had been cored in earlier drilling, and continuous sampling of these reflectors was an important objective of Leg 43.

Another major acoustic reflector in the basin that was identified in early profiler records is Horizon $\beta$ (Ewing et al., 1966; Windisch et al., 1968). Horizon $\beta$ is the top of a zone of acoustically laminated sediments normally underlying a non-laminated interval beneath "Horizon $A$ ". Piston cores taken where this reflector crops out north of San Salvador contained shallowwater Aptian-Albian sediments and deep-water Cenomanian sediments (Saito et al., 1966; Windisch et al., 1968). Another core taken near the outcrop of a slightly deeper horizon $(B)$ in the same area was found to contain shallow-water Neocomian sediments. Horizon $\beta$ was cored in the outcrop area by the Deep Sea Drilling Project at Sites 4, 5, 99, and 100, yielding Lower Cretaceous limestones, chalks, and cherts. Although these sites succeeded in recovering early Atlantic sediments, they did little to date Horizon $\beta$ because of intermittent coring and poor seismic definition of Horizon $\beta$ as a reflector in the outcrop area. Two DSDP Leg 11 drill sites were more successful; at Site 101, $\beta$ was cored and correlated with the top of a sequence of lower Hauterivian or younger limestones that underlie black clays. In seismic records across the site, Horizon $\beta$ is sharp and distinct, capping a well-laminated interval above acoustic basement. At Site 105 , Horizon $\beta$ is very poorly defined in seismic records, being represented only by a single, weak and irregular reflector barely discernible above acoustic basement. Here $\beta$ is thought to represent a gradational contact between Hauterivian/Barremian limestones and overlying black clays. It seemed likely that differing lithologic contacts at the two sites could account for the dissimilar acoustic character of $\beta$, but it was critical to test this concept by further drilling in places where $\beta$ exhibits differing acoustic character. If it could be shown that the reflector is essentially a lithostratigraphic and chronostratigraphic horizon and that its acoustic character represents actual variations in lithofacies-boundary character, then seismic records would take on added importance for mapping paleosedimentation patterns and lithofacies for the Early Cretaceous Atlantic.

Another reflecting horizon of major interest for Leg 43 drilling was Horizon $A^{*}$, which lies between "Horizon $A$ " and Horizon $\beta$ and is easily detected in profiles over most of the western and central Bermuda Rise. West of the western edge of the Bermuda Rise, however, it lies within $0.1 \mathrm{sec}$ below "Horizon $A$ " and can seldom be detected in seismic records. East of about $67^{\circ} \mathrm{W}$ on 
the western Bermuda Rise, Horizon $A^{*}$ diverges below "Horizon $A$ ", and the $A-A$ * interval reaches a maximum thickness of about 500-600 meters near Bermuda; Horizon $A^{*}$ also becomes a much stronger reflector close to Bermuda. Because of the thicker $A-A *$ interval and the more reflective Horizon $A^{*}$ near Bermuda, and because of the tentative correlation of the $A-A *$ interval with multicolored (presumably volcanogenic) clays at Site 105, it was thought that Bermuda might represent a source area for volcanogenic material comprising the $A-A^{*}$ interval. However, this working hypothesis was subsequently disproved by drilling at both Sites 386 and 387 (see Summary and Conclusions).

Four primary sites were originally planned to study the spatial and temporal variations in lithofacies comprising Horizons $\beta, A^{*}$, and the reflectors of "Horizon $A$ '. Time constraints and mechanical difficulties limited the number of sites which could be drilled to two; thus, major questions such as position of the westward transformation of "Horizon $A$ " from chert to hiatus remain unresolved by direct sampling. However, because the two sites drilled encompass a wide spectrum of acoustic facies normally associated with the reflectors in the western North Atlantic, they provide a sound basis for the interpretation of acoustic stratigraphy in the basin. We attempted to core the reflectors as continuously as possible within the time available in order to avoid missing important lithologic and biostratigraphic boundaries.

In addition to resolving the general lithostratigraphic and acoustic stratigraphic objectives outlined above, drill sites on the Bermuda Rise were located to determine more precisely crustal ages within the Keathley magnetic lineations ( $M$-series) and the Cretaceous "quiet zone," and thereby to improve the calibration of North Atlantic spreading history. This calibration is essential to evaluate such hypotheses as the Cretaceous fast-spreading episode which Hays and Pitman (1973) have used to explain the Upper Cretaceous marine transgression and subsequent Cenozoic regression. Both drill sites are located in a part of the western Atlantic that has been systematically surveyed (magnetics, bathymetry), and they are at a latitude where the Keathley magnetic anomalies are well-defined (Vogt et al., 1971).

\section{Specific Objectives}

Site 386 lies about $140 \mathrm{~km}$ southeast of Bermuda (Figure 1) on a portion of the rise where relatively thick (up to $1 \mathrm{~km}$ ) sediments unconformably blanket the irregular basement topography. This region has been extensively surveyed on recent cruises of USNS Wilkes and USNS Kane, and its acoustic structure is relatively well known. Three distinct reflectors are commonly observed. The upper reflector is the strongest and it lies 0.1 to $0.5 \mathrm{sec}$ below the sea floor (Figure 2); a pair of reflectors 0.1 to $0.2 \mathrm{sec}$ deeper are usually about $0.1 \mathrm{sec}$ apart, but they are sometimes indistinguishable because of the bubble pulse. The uppermost reflector merges with the acoustically opaque Bermuda Pedestal and fades out westward on the Bermuda Rise, but the deeper reflector pair can be traced seismically into the western part of the basin. All three of these reflectors classically have been grouped into "Horizon $A$. ."

Within deep depressions in the basement topography, a fourth, deeper reflector is observed (presumably Horizon $A^{*}$ ), and it is usually much weaker than the shallower reflectors. At the time Site 386 was drilled, there was some question whether the deepest reflector was Horizon $A^{*}$ because earlier studies suggested that Horizon $\beta$ might extend this far east (Schneider, 1969). However, if $\beta$ is at least roughly chronostratigraphic, the sea floor at Site 386 is about 20 m.y. too young for $\beta$ limestones to be present. The Challenger seismic profile between Sites 386 and 387 subsequently showed that this deep reflector correlates with Horizon $A^{*}$ on the western Bermuda Rise.

Site 386 was drilled near the eastern limit of the region where the major acoustic horizons could be more or less continuously traced in seismic profiler records. Establishing the nature of the horizons was an important step in determining the regional lithostratigraphic and chronostratigraphic relationships of the reflectors. Specific drilling objectives at Site 386 were to answer the following questions:

1) What is the age and lithofacies of the shallow reflector that merges with the Bermuda Pedestal? Does its seismic relationship to the Bermuda Pedestal reflect all or part of the volcanic and/or denudational history of Bermuda?

2) What are the ages and lithofacies of the underlying pair of reflectors? Does either correspond to the lower to middle Eocene cherts previously encountered on the Bermuda Rise?

3) Does the deepest intrasediment reflector (Horizon $\left.A^{*}\right)$ correlate with multicolored clay, black clay, or limestone facies? What is the nature of the sediments above basalt? Were Cretaceous black clays deposited at the ridge crest? Is there any indication of Bermudan volcanism in these older sediments?

4) Site 386 lies about $90 \mathrm{~km}$ east of the youngest anomaly $(M-0)$ in the Atlantic Keathley Sequence. What is the age of the oldest sediment and the basaltic basement? Does this age confirm the Larson-Pitman agedating scheme for the Keathley magnetic-anomaly sequence $(M$-series)?

\section{OPERATIONS}

Upon completion of emergency bow thruster repairs we departed Bermuda at $0530 \mathrm{hr}$ (0930Z) 24 July 1975 enroute to Site 386. Because of two detailed geophysical surveys conducted southeast of Bermuda by USNS Kane and USNS Wilkes, the bathymetry and acoustic stratigraphy in the area of Site $\mathbf{3 8 6}$ are exceptionally well known (see Bowles, this volume). Upon departing Bermuda Challenger crossed this survey area on a course of $166^{\circ}$ PGC (Figure 3).

The drill site is located near the southern edge of the survey area, close to the intersection of two Kane seismic reflection profiles that clearly show the acoustic horizons discussed earlier (Figure 3). Site 386 lies near the southern edge of a northwest-trending fracture valley, probably formed as a transform fault at the crest of the Cretaceous Mid-Atlantic Ridge. 


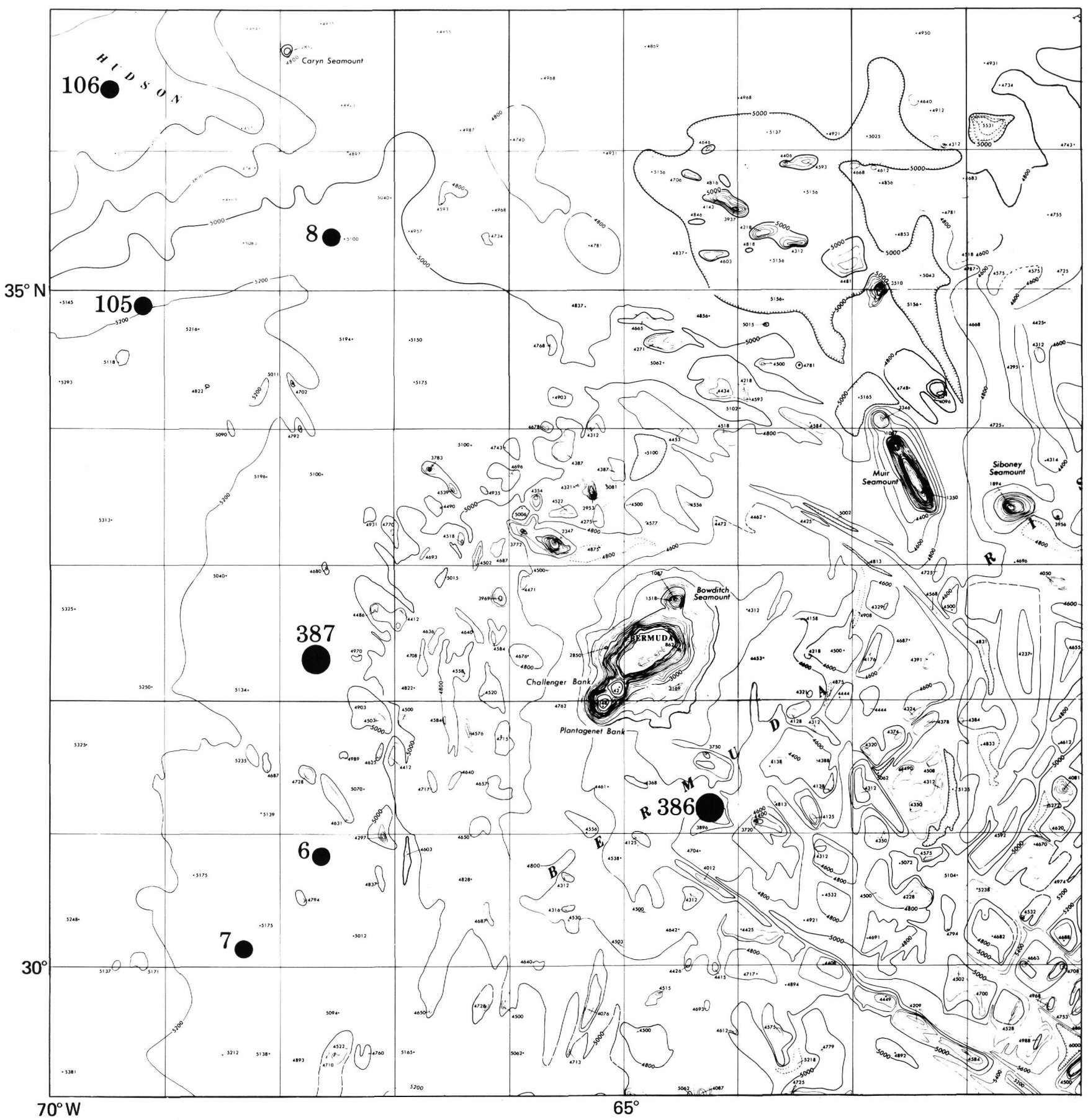

Figure 1. Bathymetric map of the central Bermuda Rise showing the position of Sites 386 and 387. Earlier DSDP boreholes are indicated. Depths in uncorrected meters.

Crossing the valley on a course of $155^{\circ}$ PGC, we could identify all acoustic horizons seen in the reference profiles. At $2122 \mathrm{Z}$ on 24 July 1975 we slowed to 6 knots to improve the seismic record, and at $2135 \mathrm{Z}$ we reached the base of a -3857 meter peak south of Site 386 ; a Williamson turn brought us back across the site on course $335^{\circ}$ PGC. A pre-soaked beacon was dropped at $2202 \mathrm{Z}$, and all towed sensors were retrieved as we turned to track the beacon to the bottom.
Satellite fixes 678 through 705 yielded an average position of $31^{\circ} 11.21^{\prime} \mathrm{N}, 64^{\circ} 14.94^{\prime} \mathrm{W}$ for Site 386 . Early on 29 July the teletype unit of the satellite-navigation system failed and no further satellite fixes were received on Leg 43. Thus, the Challenger track leaving Site 386 could not be as precisely located as the approach. When departing Site 386, the first LORAN C fix was obtained at $2040 \mathrm{Z}, 31$ July 1975 , but this fix was of marginal quality. 

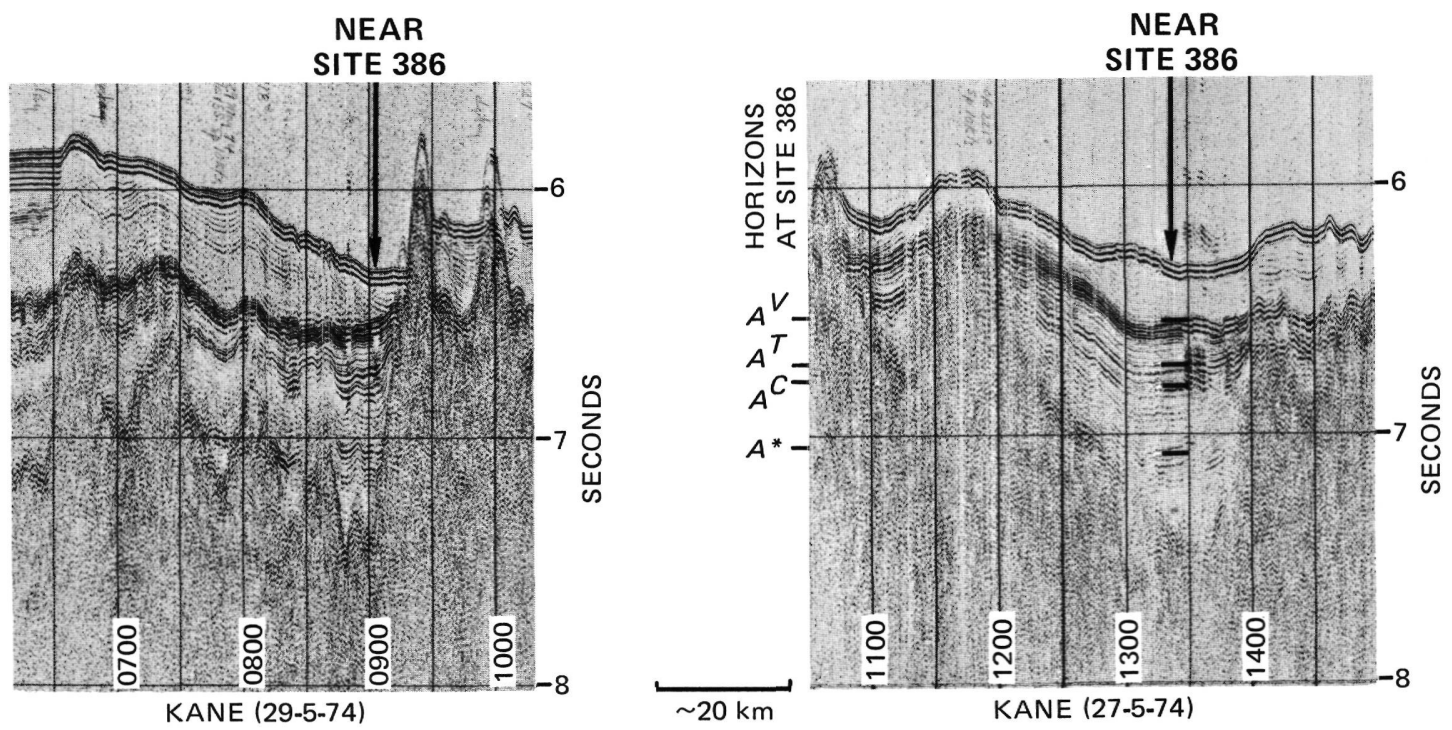

Figure 2. Kane profiler records near Site 386. Location in Figure 3.

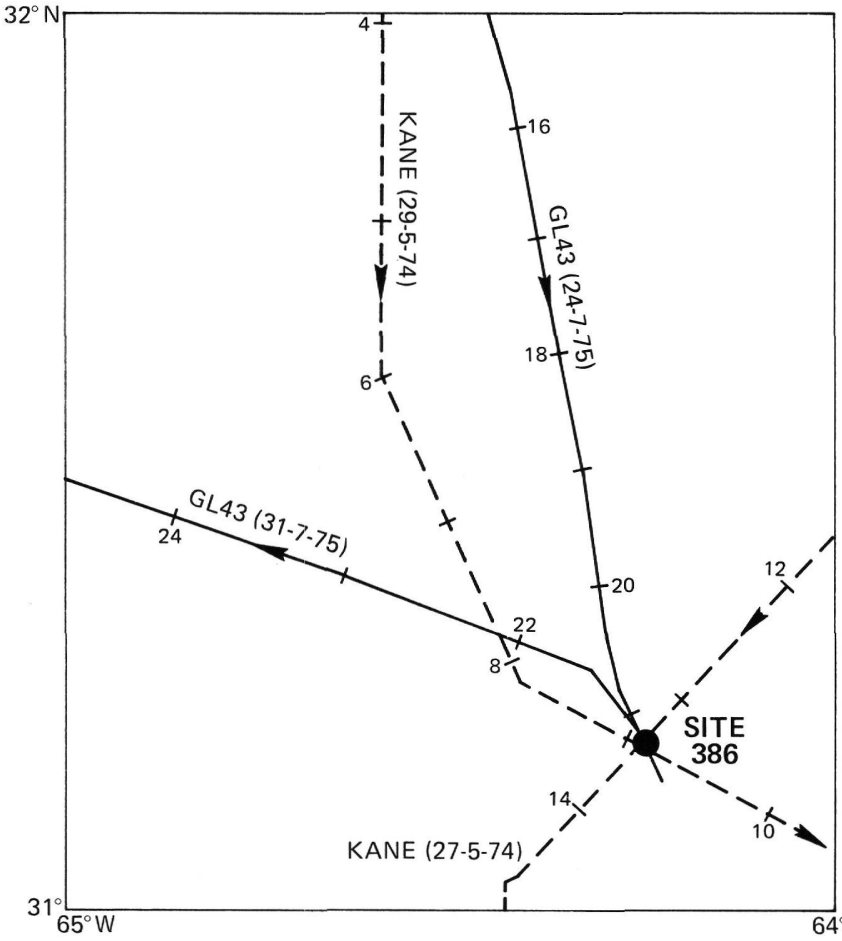

Figure 3. Tracks of Glomar Challenger and Kane in the vicinity of Site 386. Dates and hours are annotated along the tracks (Challenger times in GMT).

PDR water depth at Site 386 was 4782 meters (Matthews Area 13), which agreed closely with the 4783 meter drill-pipe value accepted as true water depih.

The site plan was to core as continuously as possible through the major acoustic horizons, and to core less continuously in the intervals between. Core 1 (52.6-62.1 m) was brought on board at 0512 hours on 25 July 1975 (Table 1, Figure 4). Continuous coring beginning with Core $3(138.0-147.2 \mathrm{~m})$ established that the shallowest reflector results from volcaniclastic, sandy turbidites originating from Bermuda.

Very slow drilling was encountered between Cores 19 and 26 (413.6-489.8 m; see Figure 4). Drilling times through cemented calcareous turbidites in this interval averaged about $9 \mathrm{~min} /$ meter and in Core 19 were as high as $14 \mathrm{~min} / \mathrm{meter}$. The top of this formation correlates with Horizon $A^{c}$.

Drilling times between about 550 and 880 meters remained below $6 \mathrm{~min} /$ meter. Very slow drilling (10 $\mathrm{min} / \mathrm{m}$ average; maximum $17 \mathrm{~min} / \mathrm{m}$ ) was encountered late on 29 July well down into the black claystone unit. This abrupt doubling of drilling time began in Core 57 (878.9-888.3 m) and did not coincide with any apparent lithologic change or acoustic reflector. For this reason, and because segments of small-gage core several 10's of $\mathrm{cm}$ long were recovered, it was feared that the bit was partially plugged, or that the rollercone bearings were failing. Basalt was recovered in Core 66, which arrived on deck at $0605 \mathrm{Z}$ hours, 31 July, after 5 hours 22 minutes drilling time. The core recovered 1.9 meters of weathered basalt from the 9.6 meters cored. The plastic liner was jammed, perhaps accounting for the slow drilling into basalt. When the bit was recovered it appeared undamaged and relatively unworn; the slow drilling in the cores above the basalt thus remains unexplained.

Operationally Site 386 was successful and problems few. For a brief period, winds gusting to $35 \mathrm{mph}$ combined with currents resulted in maximum load on the main propulsion system and loss of acoustics. The acoustics problem was alleviated by selecting an alternate hydrophone, a slight course change, and 30-minutes of precautionary manual positioning.

After the drill string was retrieved well clear of the mud line, the ship was allowed to drift off the beacon to reduce current drag on the pipe and speed retrieval. After drifting from 1415Z, 31 July, Challenger came up to a speed of 5 knots at $2010 \mathrm{Z}$ on course $153^{\circ}$ PGC, made a Williamson turn at 2025-2038Z, and recrossed 
TABLE 1

Coring Summary, Site 386

\begin{tabular}{|c|c|c|c|c|c|c|c|c|c|c|}
\hline \multirow{2}{*}{$\frac{\text { Core }}{1}$} & \multirow{2}{*}{$\begin{array}{c}\begin{array}{c}\text { Time } \\
\text { (Day-Hour) }\end{array} \\
25-0512\end{array}$} & \multicolumn{2}{|c|}{$\begin{array}{l}\text { Total Depth } \\
\text { (m) }\end{array}$} & \multicolumn{2}{|c|}{$\begin{array}{l}\text { Sub-Bottom } \\
\text { Depth } \\
\text { (m) }\end{array}$} & \multirow{2}{*}{$\begin{array}{c}\begin{array}{c}\text { Cored } \\
(\mathrm{m})\end{array} \\
9.5\end{array}$} & \multirow{2}{*}{$\begin{array}{c}\begin{array}{c}\text { Recovered } \\
(\mathrm{m})\end{array} \\
8.15\end{array}$} & \multirow{2}{*}{$\begin{array}{c}\begin{array}{c}\text { Recov- } \\
\text { ered } \\
(\%)\end{array} \\
86\end{array}$} & \multirow{2}{*}{$\begin{array}{l}\text { Lithology } \\
\text { anno ooze }\end{array}$} & \multirow{2}{*}{$\frac{\mathrm{Age}^{\mathrm{b}}}{\text { eist. }}$} \\
\hline & & 4845.6 & 4855.1 & 52.6 & 62.1 & & & & & \\
\hline 2 & $25-0719$ & 4893.1 & 4902.6 & 100.1 & 109.6 & 9.5 & 1.10 & 12 & Grn.-gray clay & U. Mio. \\
\hline 3 & $25-0900$ & 4931.0 & 4940.2 & 138.0 & 147.2 & 9.2 & 0.73 & 8 & Grn.-gray clay & \\
\hline 4 & $25-1025$ & 4940.2 & 4949.8 & 147.2 & 156.8 & 9.6 & 8.40 & 88 & Clay, nanno ooze & L. Mio. \\
\hline 5 & $25-1120$ & 4949.8 & 4959.3 & 156.8 & 166.3 & 9.5 & 6.05 & 64 & Calc. turbidites & U. Olig. \\
\hline 6 & $25-1315$ & 4959.3 & 4968.8 & 166.3 & 175.8 & 9.5 & 5.10 & 53 & Volcanogenic sand turbidites & M. Olig. \\
\hline 7 & $25-1442$ & 4968.8 & 4978.3 & 175.8 & 185.3 & 9.5 & 4.30 & 45 & Volcanogenic sand turbidites & M. Olig. \\
\hline 8 & $25-1600$ & 4978.3 & 4987.7 & 185.3 & 194.7 & 9.4 & 5.80 & 62 & Volcanogenic sand turbidites & M. Olig. \\
\hline 9 & $25-1745$ & 4997.3 & 5006.8 & 204.3 & 213.8 & 9.5 & 3.70 & 39 & Volcanogenic sand turbidites & M. Olig. \\
\hline 10 & $25-1925$ & 5016.3 & 5025.9 & 223.3 & 232.9 & 9.5 & 0.07 & 1 & Volcanogenic sand turbidites & M. Olig. \\
\hline 11 & $25-2100$ & 5044.9 & 5054.4 & 251.9 & 261.4 & 9.5 & 3.75 & 39 & Volcanogenic sand turbidites & L. Olig. \\
\hline 12 & $25-2238$ & 5073.4 & 5083.0 & 280.4 & 290.0 & 9.6 & 5.90 & 61 & Volcanogenic sand turbidites & L. Olig. \\
\hline 13 & $26-0027$ & 5102.0 & 5111.5 & 309.0 & 318.5 & 9.5 & 3.25 & 34 & Volcanogenic sand turbidites & M./U. Eoc. \\
\hline 14 & $26-0216$ & 5121.0 & 5130.4 & 328.0 & 337.4 & 9.4 & 9.65 & 103 & Silic. turbidites & M. Eoc. \\
\hline 15 & $26-0406$ & 5139.9 & 5149.4 & 346.9 & 356.4 & 9.5 & 9.40 & 99 & Silic. turbidites & M. Eoc. \\
\hline 16 & $26-0537$ & 5159.0 & 5168.5 & 366.0 & 375.5 & 9.5 & 6.40 & 67 & Silic. turbidites & M. Eoc. \\
\hline 17 & $26-0715$ & 5178.0 & 5187.5 & 385.0 & 394.5 & 9.5 & 9.70 & 102 & Silic. turbidites & M. Eoc. \\
\hline 18 & $26-1020$ & 5197.0 & 5206.6 & 404.0 & 413.6 & 9.6 & 9.50 & 99 & Silic. and calc. turbidites & M. Eoc. \\
\hline 19 & $26-1350$ & 5206.6 & 5216.1 & 413.6 & 423.1 & 9.5 & 3.85 & 41 & Calc. turbidites & M. Eoc. \\
\hline 20 & $26-1645$ & 5216.1 & 5225.7 & 423.1 & 432.7 & 9.6 & 5.55 & 58 & Calc. turbidites & M. Eoc. \\
\hline 21 & 26-1920 & 5225.7 & 5235.1 & 432.7 & 442.1 & 9.5 & 6.75 & 71 & Calc. turbidites & M. Eoc. \\
\hline 22 & $26-2150$ & 5235.1 & 5244.7 & 442.1 & 451.7 & 9.6 & 6.88 & 72 & Calc. turbidites & M. Eoc. \\
\hline 23 & $27-0010$ & 5244.7 & 5254.2 & 451.7 & 461.2 & 9.6 & 7.65 & 80 & Calc. turbidites & M. Eoc. \\
\hline 24 & $27-0303$ & 5254.2 & 5263.8 & 461.2 & 470.8 & 9.6 & 6.46 & 67 & Calc. turbidites & M. Eoc. \\
\hline 25 & $27-0540$ & 5263.8 & 5273.3 & 470.8 & 480.3 & 9.5 & 9.70 & 102 & Calc. turbidites & M. Eoc. \\
\hline 26 & $27-0851$ & 5273.3 & 5282.8 & 480.3 & 489.8 & 9.5 & 6.25 & 66 & Grn.-gray clayst. & L. Eoc. \\
\hline 27 & $27-1050$ & 5282.8 & 5292.3 & 489.8 & 499.4 & 9.5 & 5.48 & 57 & Cherty clayst. & L. Eoc. \\
\hline 28 & $27-1240$ & 5292.3 & 5301.9 & 499.4 & 508.9 & 9.6 & 4.85 & 50 & Cherty clayst. & L. Eoc. \\
\hline 29 & $27-1430$ & 5301.9 & 5311.4 & 508.9 & 518.4 & 9.5 & 4.90 & 50 & Cherty clayst. & L. Eoc. \\
\hline 30 & $27-1700$ & 5311.4 & 5320.9 & 518.4 & 528.0 & 9.5 & 8.20 & 86 & Cherty clayst. & L. Eoc. \\
\hline 31 & $27-1940$ & 5330.4 & 5340.0 & 537.4 & 547.0 & 9.6 & 9.71 & 101 & Claystone and rad mudstone & L. Eoc. \\
\hline 32 & $27-2200$ & 5349.2 & 5358.8 & 556.2 & 565.8 & 9.6 & 9.60 & 100 & Rad mudstone & L. Eoc. \\
\hline 33 & $27-2359$ & 5368.2 & 5377.7 & 575.2 & 584.7 & 9.5 & 4.35 & 46 & Rad mudstone & L. Eoc. \\
\hline 34 & $28-0215$ & 5396.7 & 5405.9 & 603.7 & 612.9 & 9.2 & 9.55 & 104 & Rad mudstone & L. Eoc.-U. Paleo. \\
\hline 35 & $28-0445$ & 5425.0 & 5434.5 & 632.0 & 641.5 & 9.5 & 8.61 & 91 & Red claystone & M. Paleo.-M. Maestr. \\
\hline 36 & $28-0630$ & 5434.5 & 5443.8 & 641.5 & 650.8 & 9.3 & 7.12 & 77 & Red claystone & U. Cretac. \\
\hline 37 & 28-0905 & 5462.9 & 5472.4 & 669.9 & 679.4 & 9.5 & Trace & $<1$ & - & U. Cretac. \\
\hline 38 & $28-1100$ & 5481.9 & 5491.5 & 688.9 & 698.5 & 9.6 & 9.60 & 100 & Banded zeol. claystone & U. Cretac. \\
\hline 39 & $28-1300$ & 5491.5 & 5501.0 & 698.5 & 708.0 & 9.5 & 9.85 & 103 & Banded zeol. claystone & U. Cenom. \\
\hline 40 & $28-1450$ & 5501.0 & 5510.5 & 708.0 & 717.5 & 9.5 & 4.30 & 45 & Banded zeol. claystone & U. Cenom. \\
\hline 41 & $28-1620$ & 5510.5 & 5520.0 & 717.5 & 727.0 & 9.5 & 8.60 & 91 & Banded zeol. claystone & U. Cenom. \\
\hline 42 & $28-1755$ & 5520.0 & 5529.3 & 727.0 & 736.3 & 9.3 & 7.25 & 77 & Grn.-gray and blk. claystone & U. Cenom. \\
\hline 43 & $28-1930$ & 5529.3 & 5538.8 & 736.3 & 745.8 & 9.5 & 5.74 & 63 & Grn.-gray and blk. claystone & U. Cenom. \\
\hline 44 & $28-2115$ & 5538.8 & 5548.3 & 745.8 & 755.3 & 9.5 & 6.35 & 67 & Grn.-gray and blk. claystone & U. Cenom. \\
\hline 45 & $28-2315$ & 5557.8 & 5567.4 & 764.8 & 774.4 & 9.5 & 9.95 & 105 & Grn.-gray and blk. clay stone & U. Cenom. \\
\hline 46 & $29-0055$ & 5567.4 & 5576.8 & 774.4 & 783.8 & 9.4 & 8.18 & 82 & Grn.-gray and blk. claystone & U. Cenom. \\
\hline 47 & $29-0303$ & 5576.8 & 5586.3 & 783.8 & 793.3 & 9.5 & 8.80 & 93 & Grn.-gray and blk. claystone & L. Cenom. \\
\hline 48 & $29-0507$ & 5586.3 & 5595.8 & 793.3 & 802.8 & 9. & 3.50 & 37 & Grn.-gray and blk. claystone & L. Cenom. \\
\hline 49 & $29-0707$ & 5595.8 & 5605.3 & 802.8 & 812.3 & 9.5 & 5.65 & 59 & Grn.-gray and blk. claystone & L. Cenom. \\
\hline 50 & 29-0905 & 5605.3 & 5614.9 & 812.3 & 821.9 & 9.5 & 7.00 & 74 & Grn.-gray and blk. claystone & L. Cenom. \\
\hline 51 & $29-1105$ & 5614.9 & 5624.4 & 821.9 & 831.4 & 9.5 & 9.70 & 102 & Grn.-gray and blk. claystone & L. Cenom. \\
\hline 52 & $29-1303$ & 5624.4 & 5633.9 & 831.4 & 840.9 & 9.5 & 8.45 & 89 & Grn.-gray and blk. claystone & U. Alb. \\
\hline 53 & $29-1440$ & 5633.9 & 5643.5 & 840.9 & 850.4 & 9.5 & 5.65 & 59 & Grn.-gray and blk. claystone & U. Alb. \\
\hline 54 & $29-1645$ & 5643.5 & 5652.9 & 850.4 & 859.9 & 9.5 & 9.25 & 97 & Grn.-gray and blk. claystone & U. Alb. \\
\hline 55 & $29-1845$ & 5652.9 & 5662.3 & 859.9 & 869.3 & 9.4 & 8.20 & 87 & Grn.-gray and blk. claystone & U. Alb. \\
\hline 56 & $29-2010$ & 5662.3 & 5671.9 & 869.3 & 878.9 & 9.5 & 6.47 & 68 & Grn.-gray and blk. claystone & U. Alb. \\
\hline 57 & $29-2305$ & 5671.9 & 5681.3 & 878.9 & 888.3 & 9.4 & 8.00 & 85 & Grn.-gray and blk. claystone & U. Alb. \\
\hline 58 & $30-0235$ & 5681.3 & 5690.7 & 888.3 & 897.7 & 9.5 & 9.50 & 100 & Grn.-gray and blk. claystone & M. Alb. \\
\hline 59 & $30-0450$ & 5690.7 & 5700.2 & 897.7 & 907.2 & 9.5 & 7.10 & 75 & Grn.-gray and blk. claystone & M./L. Alb. \\
\hline 60 & $30-0733$ & 5700.2 & 5709.8 & 907.2 & 916.8 & 9.6 & 9.07 & 94 & Grn.-gray and blk. claystone & L. Alb. \\
\hline
\end{tabular}


TABLE 1 - Continued

\begin{tabular}{|c|c|c|c|c|c|c|c|c|c|c|}
\hline \multirow{2}{*}{$\frac{\text { Core }}{61}$} & \multirow{2}{*}{$\begin{array}{c}\begin{array}{c}\text { Time } \\
\text { (Day-Hour) }\end{array} \\
30-1005\end{array}$} & \multicolumn{2}{|c|}{$\begin{array}{l}\text { Total Deptha } \\
\text { (m) }\end{array}$} & \multicolumn{2}{|c|}{$\begin{array}{l}\text { Sub-Bottom } \\
\text { Depth } \\
\text { (m) }\end{array}$} & \multirow{2}{*}{$\begin{array}{c}\begin{array}{c}\text { Cored } \\
(\mathrm{m})\end{array} \\
9.5\end{array}$} & \multirow{2}{*}{$\begin{array}{c}\begin{array}{c}\text { Recovered } \\
(\mathrm{m})\end{array} \\
7.65\end{array}$} & \multirow{2}{*}{$\begin{array}{c}\begin{array}{c}\text { Recov- } \\
\text { ered } \\
(\%)\end{array} \\
81\end{array}$} & \multirow[t]{2}{*}{ Lithology } & \multirow{2}{*}{$\frac{\text { Age }^{\mathrm{b}}}{\text { L. Alb. }}$} \\
\hline & & 5709.8 & 5719.3 & 916.8 & 926.3 & & & & & \\
\hline 62 & $30-1225$ & 5719.3 & 5728.8 & 926.3 & 935.8 & 9.5 & 8.35 & 88 & Grn.-gray and blk. claystone & L. Alb. \\
\hline 63 & $30-1530$ & 5728.8 & 5738.3 & 935.8 & 945.3 & 9.5 & 5.00 & 53 & Grn.-gray and blk. claystone & L. Alb. \\
\hline 64 & $30-1907$ & 5738.3 & 5747.8 & 945.3 & 954.8 & 9.5 & 7.95 & 84 & Grn.-gray and blk. claystone & L. Alb. \\
\hline 65 & $30-2308$ & 5747.8 & 5757.2 & 954.8 & 964.2 & 9.4 & 4.73 & 50 & Grn.-gray and blk. claystone & L. Alb. \\
\hline 66 & $30-0605$ & 5757.2 & 5766.8 & 964.2 & 973.8 & 9.6 & 1.90 & 20 & Basalt & \\
\hline \multirow{2}{*}{\multicolumn{4}{|c|}{ Total }} & \multirow{2}{*}{\multicolumn{2}{|c|}{$\begin{array}{l}\text { Total cored } \\
\text { Total recovered }\end{array}$}} & 626.7 & & & & \\
\hline & & & & & & & 438.15 & & & \\
\hline \multirow{3}{*}{\multicolumn{4}{|c|}{$\begin{array}{ll}\% \text { recovery in intervals cored } & =69.9 \% \\
\% \text { recovery of depth drilled } & =45.0 \% \\
\% \text { of depth drilled which was cored } & =64.4 \%\end{array}$}} & & & & & & & \\
\hline & & & & & & & & & & \\
\hline & & & & & & & & & & \\
\hline
\end{tabular}

${ }^{\mathrm{a}}$ From rig floor, 10 meters above sea level.

${ }^{b_{U}}=$ upper, $\mathrm{L}=$ lower.

the beacon at 2053Z. We attempted an unsuccessful sonobuoy recording when recrossing Site 386. At $2134 \mathrm{Z}, 31$ July we increased speed to full and changed course to $290^{\circ}$ PGC enroute to Site 387 .

\section{LITHOLOGY}

\section{Introduction}

The main objectives of Site 386 were to determine the age and lithology of the seismic reflectors in the area, to gather information about the timing of Bermudan volcanism, and to determine the age of the crust.

The hole contains a variety of lithologic units ranging from late Pleistocene marly nannofossil ooze at the top, through thick Tertiary sediments of turbidite origin, to red pelagic claystones, and finally green and black claystones of Middle to Lower Cretaceous age overlying basalt. Except for the upper 62 meters of Quaternary marly nannofossil ooze and clay, the sediments at Site 386 were nearly continuously cored. Sedimentation was predominantly continuous but at highly variable rates; thus the section provides important information about the sedimentary history of the Bermuda Rise. Seven main lithologic units were defined in the hole (Table 2). The seventh unit is basalt, and it is discussed at the end of this section.

\section{Sediments}

The six sedimentary units were established on the basis of macroscopic observations and microscopic determinations on smear slides of representative samples. Both dominant and minor lithologies were studied. Unit composition was also studied by X-ray diffraction analysis of samples in order to define more precisely the mineral composition, especially in the fine $(<2 \mu \mathrm{m})$ fraction. A graphic summary of the Site 386 smear-slide determinations of composition is presented in Foldout $\mathrm{V}$ in the cover pocket.

\section{Unit 1 - Marly Nannofossil Ooze and Brown Clay $(0->62.1 \mathrm{~m})$}

The upper boundary of Unit 1 is at the sea floor, and its lower boundary falls in the uncored interval between Cores 1 and 2 (62.1 to $100.0 \mathrm{~m}$ ). Core 1 recovered 8.15 meters of lower Pleistocene yellowish brown silty clays with both pelagic and terrigenous components. A smear-slide summary based on 12 samples averages 34 per cent total clay, and 64 per cent biogenic carbonate (34\% nannofossils, $19 \%$ foraminifers, and $11 \%$ unspecified carbonate which probably represents broken foraminifer tests). The total carbonate content is highly variable, ranging between 0 and 78 per cent; this clearly reflects the episodic influence of terrigenous sedimentation and the variable depth of the CCD during the Pleistocene.

X-ray data show three samples to contain about 15 per cent quartz and 5 per cent feldspar. The clay minerals (summed up to $100 \%$ of the $<2 \mu \mathrm{m}$ fraction) include mica/illite $(48 \%$ average), montmorillonite (34\%), chlorite (>9\%), and kaolinite $(9 \%)$ (Koch and Rothe, this volume). Comparison of the smear-slide and X-ray data show that quartz generally was not detected in the smear slides because of its fine grain size, whereas the $\mathrm{X}$-ray data locally indicate up to 20 per cent quartz.

Grain-size data identify the sediments as clay and silty clay (two samples). Organic carbon content ranges from 0.1 to 0.2 per cent.

\section{Unit 2 - Quartzose Green-Gray Clay (62.1-100.0 to $148.1 \mathrm{~m})$}

Unit 2 is represented by Core 2 through Core 4 , Sec. 1 , Sample 4-1, $86 \mathrm{~cm}$, but the overall recovery was extremely poor. Most of the sediments obtained are disturbed, stiff clays and quartose clays of greenish gray color and of middle to late Miocene age. The clays and silty clays have low carbonate contents $(0-6 \%, 4$ samples). According to X-ray data, Unit 2 contains about 80 per cent clay minerals, 15 per cent quartz, and 4 per cent feldspar, but only three samples were examined. Clay minerals include montmorillonite $(51 \%)$, mica/illite $(30 \%)$, kaolinite $(12 \%)$, and chlorite $(7 \%)$ (Koch and Rothe, this volume). The organic carbon content is 0.2 per cent in two samples analyzed. Near the bottom of Unit 2 there is a change of color from greenish gray to olive-gray and dark olive-gray, and the sediments become siltier.

\section{Unit 3 - Calcareous and Volcaniclastic Turbidites (148.1 to 318.5-328.0 m)}

Lithologic Unit 3 is a sequence of turbidites of volcaniclastic composition in the lower part, grading 


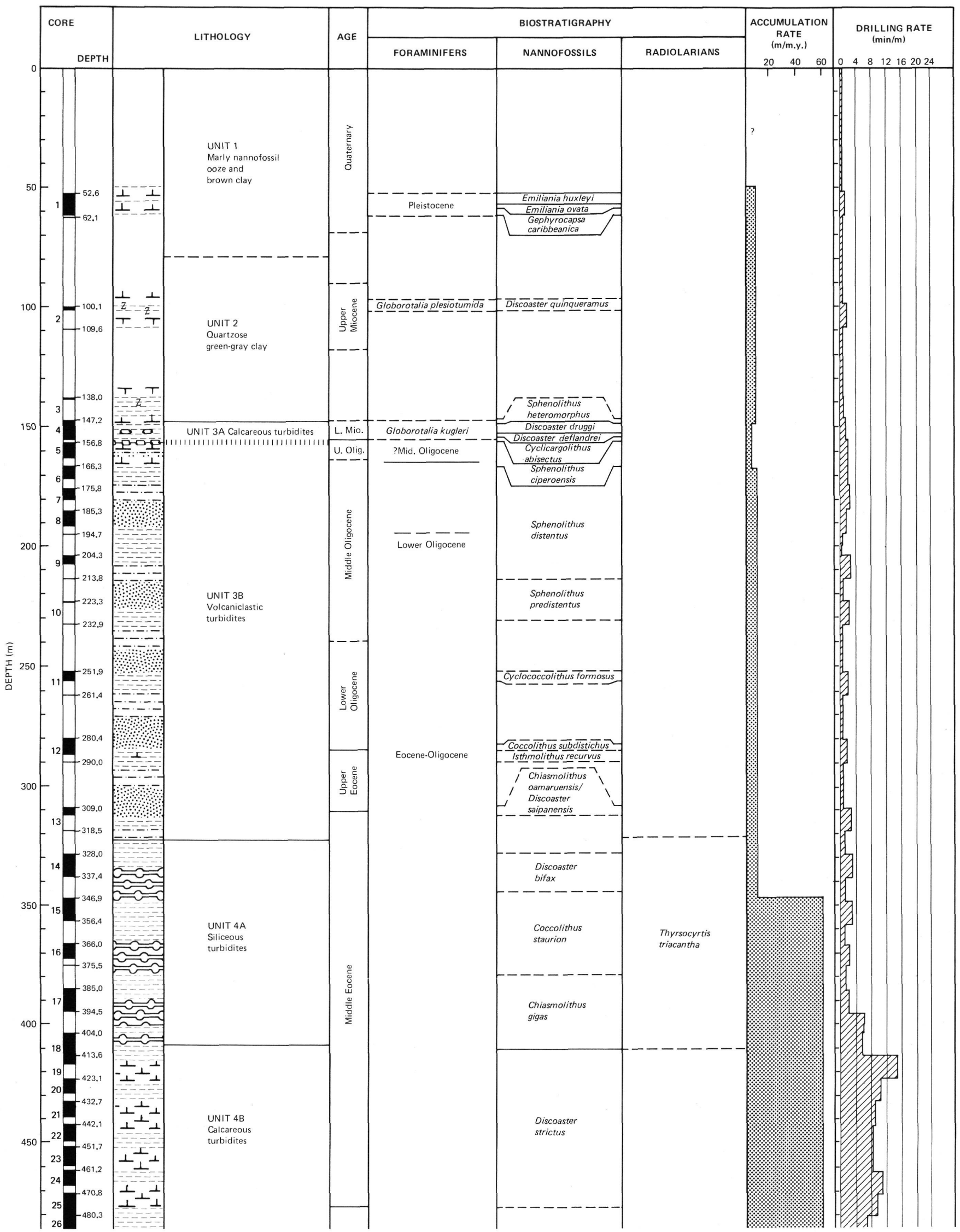

Figure 4. Graphic hole summary, Site 386. 


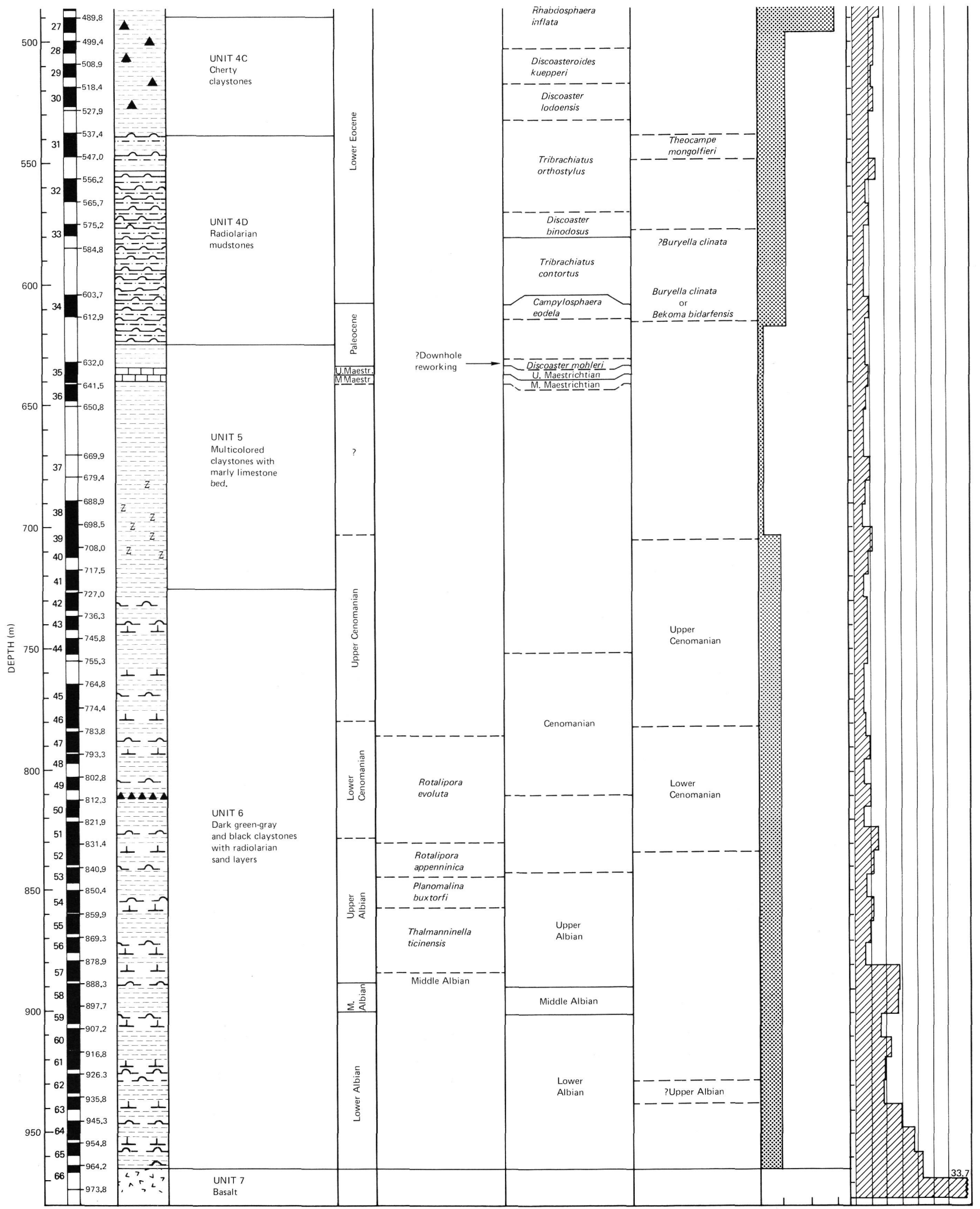

Figure 4. (Continued). 
TABLE 2

Lithologic Units, Site 386

\begin{tabular}{|c|c|c|c|c|c|}
\hline Unit & Lithology & Age & $\begin{array}{l}\text { Thickness } \\
\text { (m) }\end{array}$ & $\begin{array}{l}\text { Sub-Bottom Depth } \\
\text { at Bottom of Unit } \\
(\mathrm{m})\end{array}$ & Core \\
\hline 1 & $\begin{array}{l}\text { Marly nanno ooze and } \\
\text { brown clay }\end{array}$ & Quaternary and older & $62.1-100.1$ & $62.1-100.1$ & 1 \\
\hline 2 & Quartzose green-gray clay & $\begin{array}{l}\text { Upper to middle } \\
\text { Miocene }\end{array}$ & $48.0-86.0$ & 148.1 & 2 to $4-1: 86 \mathrm{~cm}$ \\
\hline $3 \mathrm{~A}$ & Calcareous turbidites & $\begin{array}{l}\text { Lower Miocene } \\
\text { to Upper Oligocene }\end{array}$ & 8.7 & $\begin{array}{c}156.8 \\
\text { (gradational) }\end{array}$ & $4-1: 86 \mathrm{~cm}$ to $4, \mathrm{CC}$ \\
\hline $3 \mathrm{~B}$ & Volcaniclastic turbidites & $\begin{array}{l}\text { Upper Oligocene to } \\
\text { middle Eocene }\end{array}$ & $161.7-171.2$ & $318.5-328.0$ & 5 to 13 \\
\hline $4 \mathrm{~A}$ & Siliceous turbidites & Middle Eocene & $80.5-90.0$ & 408.5 & 14 through $18-3$ \\
\hline 4B & Calcareous turbidites & M. to L. Eocene & 81.3 & 489.8 & $18-4$ to 26 \\
\hline $4 \mathrm{C}$ & Cherty claystones & Lower Eocene & 48.6 & 538.4 & 27 to $31-1: 100 \mathrm{~cm}$ \\
\hline $4 \mathrm{D}$ & Radiolarian mudstones & $\begin{array}{l}\text { Lower Eocene to } \\
\text { upper Paleocene }\end{array}$ & $74.5-93.6$ & $612.9-632.0$ & $31-1: 100 \mathrm{~cm}$ to $34, \mathrm{CC}$ \\
\hline 5 & Multicolored claystones & $\begin{array}{l}\text { Upper Maestrichtian- } \\
\text { upper Cenomanian }\end{array}$ & $92.3-111.4$ & 724.3 & 35 to $41-5: 80 \mathrm{~cm}$ \\
\hline 6 & $\begin{array}{l}\text { Dark greenish gray and } \\
\text { black claystones with } \\
\text { radiolarian sand layers }\end{array}$ & $\begin{array}{l}\text { Upper Cenomanian- } \\
\text { lower Albian }\end{array}$ & 239.9 & 964.2 & $41-5: 80 \mathrm{~cm}$ to $65, \mathrm{CC}$ \\
\hline 7 & Basalt & Lower Albian & - & $>973.8$ & 66 \\
\hline
\end{tabular}

upward into calcareous turbidites at the top. The compositional change is gradational between Core 4, Section 5, and Core 5, Section 2 . Unit 3 is divided into two sub-units on the basis of compositional differences, and the boundary between units is placed at 156.8 meters sub-bottom, between sub-units is Cores 4 and 5 .

\section{Sub-Unit $3 A-$ Calcareous Turbidites}

The upper boundary of Sub-unit 3A was placed in Core 4, Section 1, at $86 \mathrm{~cm}$, because of a marked change in both color and composition. The lower boundary is transitional and is picked between Cores 4 and 5. Subunit 3A sediments are upper Oligocene to lower Miocene dark brown and yellowish brown clays and silty clays. Subsidiary layers a few $\mathrm{cm}$ in thickness contain fine and very fine sand of white and pale yellow colors.

The sandy layers grade upward into yellowish gray nannofossil ooze. An erosional contact was observed at the base of a sandy layer in Section 5 of Core 4 at 116 $\mathrm{cm}$. The clays are moderately mottled and also contain dark brown and black small silty patches in the upper part of the sub-unit (filled burrow-mottles?).

Carbonate contents are variable, ranging from high values $(27-34 \%)$ where nannofossils are present to nil within the clays.

The only difference between Sub-unit $3 \mathrm{~A}$ and the underlying Sub-unit $3 \mathrm{~B}$ is in the composition of the sandy layers. Carbonate of the sandy layers in $3 \mathrm{~A}$ is primarily foraminifers; both planktonic and benthic species, and rare mollusk fragments were found. Thus, a shallow-water origin of at least part of this material is suggested.

Smear slides of nine samples indicate an average composition of 48 per cent clay (range 15-95\%), 27 per cent nannofossils (range 0-77\%), 4 per cent foraminifers and 4 per cent unspecified carbonate (most probably foraminiferal debris). Among the noncalcareous detrital components, quartz and feldspar locally are common according to X-ray data. One sample contained about 50 per cent detrital apatite. The sediment represents an apatite placer (Core 4, Section 2, $4 \mathrm{~cm}$; Figure 5), but its origin is uncertain.

Clay minerals comprise an average of 60 per cent (range $34-80 \%, 4$ samples) consisting of mica-illite, 24-72 per cent (smear slides suggest muscovite), 42 per cent montmorillonite (range 28-54\%), and small amounts of chlorite and kaolinite (0-14\%) (Koch and Rothe, this volume).

Grain-size data indicate clay, silty clay, and also equal amounts of sand, silt, and clay within the coarse intercalations of $3 \mathrm{~A}$. Organic carbon averages 0.1 per cent in 3 samples.

A dominantly turbidite origin of Sub-unit $3 \mathrm{~A}$ is suggested by megascopic grading of sand layers and by grading determined by Coulter-counter analyses in finegrained sediments (McCave, this volume), as well as by the presence of occasional shallow-water debris.

\section{Sub-Unit 3B - Volcaniclastic Turbidites}

Transitional calcareous/volcaniclastic turbidites are present in the bottom of Core 4 and down to Core 5 , Section 2, $100 \mathrm{~cm}$, where the first dominantly volcaniclastic turbidite occurs. Sub-unit $3 \mathrm{~B}$ is represented by more than 162 meters of gray and brown clays, silts, and sands in Cores 5 through 13 (156.8 to $>318.5 \mathrm{~m}$ ). Beds range in age from late middle Eocene (Core 13) to late Oligocene (Cores 4, 5). These sediments are clearly defined as turbidites by common sharp basal contact of sand beds and by size grading (see Figure 11). The basal sands are usually dark in color, ranging between gray and olive, and the upward grading to silt and clay is accompanied by a change to shades of brown. Basal scour at the bottom of the sand beds locally is observed, and abundant green 


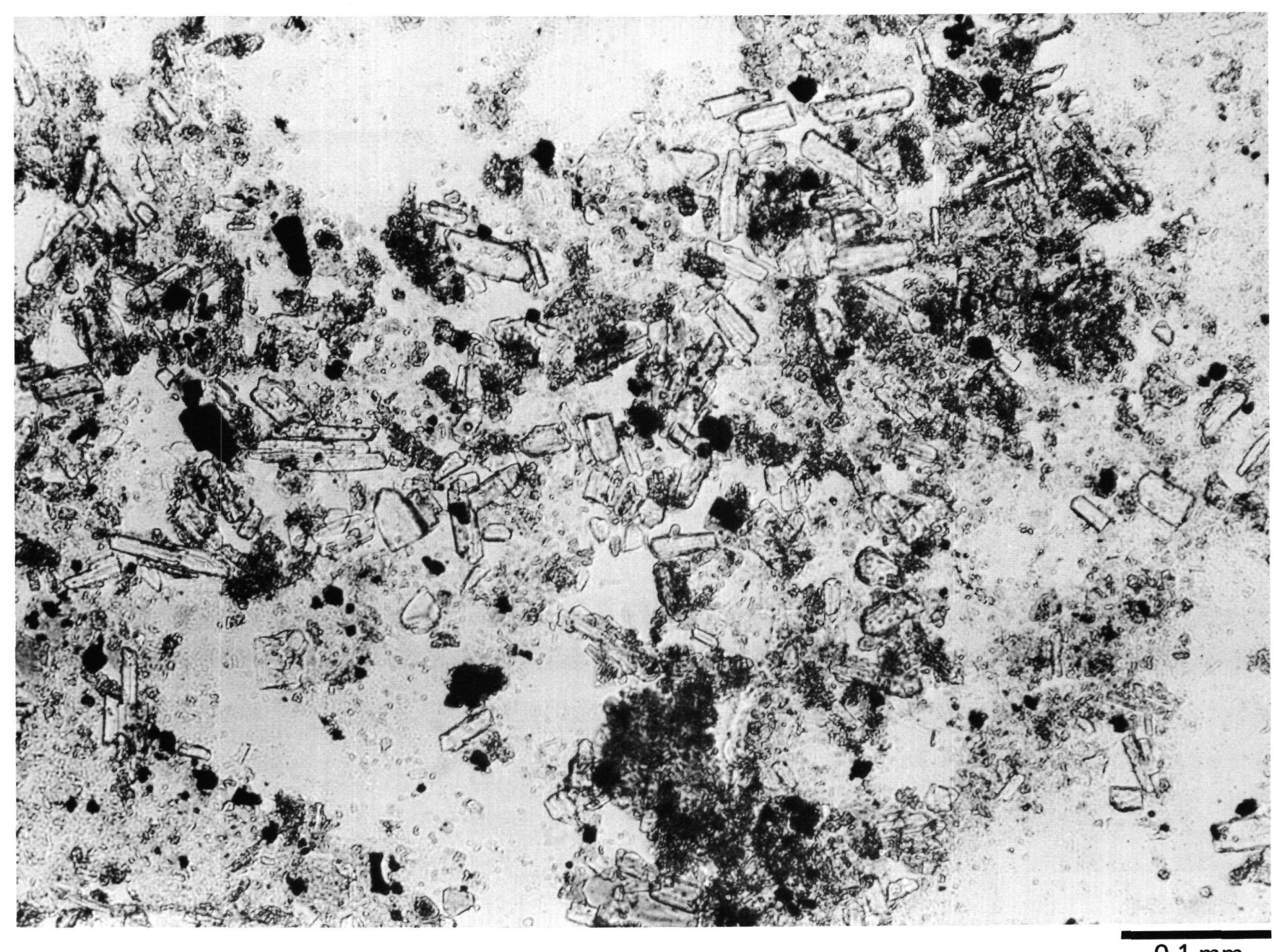

$0.1 \mathrm{~mm}$

Figure 5. Apatite "placer" from a silty layer within calcareous turbidites of Sub-unit 3A. Sample 4-2, $4 \mathrm{~cm}$; smear slide.

and black, rounded to lenticular mud clasts $0.4-3.0 \mathrm{~mm}$ long are incorporated in the beds (Figure 6). The sand beds are poorly sorted, lithified, and locally laminated. The silty members of the turbidite beds are laminated more commonly, and burrows are observed only in the clayey, upper members (Chondrites burrows occur within Core 6).

Angular mineral grains dominate in the sand beds, and they comprise an excellent heavy mineral suite (see Galehouse, this volume). Clinopyroxene is most common, with auxiliary hornblende, apatite, epidote, and rare garnet. Other components include vesicular glass, palagonite, opaques (mostly magnetite), phillipsite, and analcime. Foraminifers and shallow-water skeletal fragments including red algae (Figure 7), echinoderms, mollusks, and scarce bryozoa are minor components.

Mineralogy of the fine-grained sediments (siltstones, silty claystones, and claystones) was determined from smear slides and by X-ray analysis (Koch and Rothe, this volume). Clinopyroxene is present in amounts ranging from 2 to 4 per cent, and feldspar (0-10\%), phillipsite $(2-5 \%)$, and analcime $(2-4 \%)$ are present. The X-ray data show that zeolites were overestimated in smear- slide descriptions. Quartz was detected by X-ray only, and it is present $(2-5 \%)$ only near the boundaries of the sub-unit, where the assemblage is not dominated by volcaniclastic debris.

Clay minerals are considerably more abundant according to the X-ray results than was estimated in smear slides. An average of $15 \mathrm{X}$-ray analyses gives 79 per cent clay (range 62-95\%) whereas the average in 28 smear slides is 47 per cent (range 10-85\%). This discrepancy is partly due to selection of samples, because smear slides were concentrated on study of coarser materials. For this reason, the initial smear-slide descriptions were not adjusted to the X-ray results.

The clay mineral assemblage is dominated by montmorillonite (average of 14 samples is $63 \%$; range $0-100 \%)$. Mica (13-50\%) occurs only at the base (Sections 12-3 and 13-3) and in the upper half of the subunit. Kaolinite and chlorite are also present only within the upper part of Sub-unit 3B (8 samples in Cores 5 through 8: kaolinite $<10 \%$; range $6-13 \%$; chlorite $<10 \%$, range $7-30 \%$ ). Organic carbon content is low $(0.0-0.1 \%, 10$ samples $)$. Carbonate contents are variable but low $(<15 \%, 32$ samples, range $0-40 \%)$. 


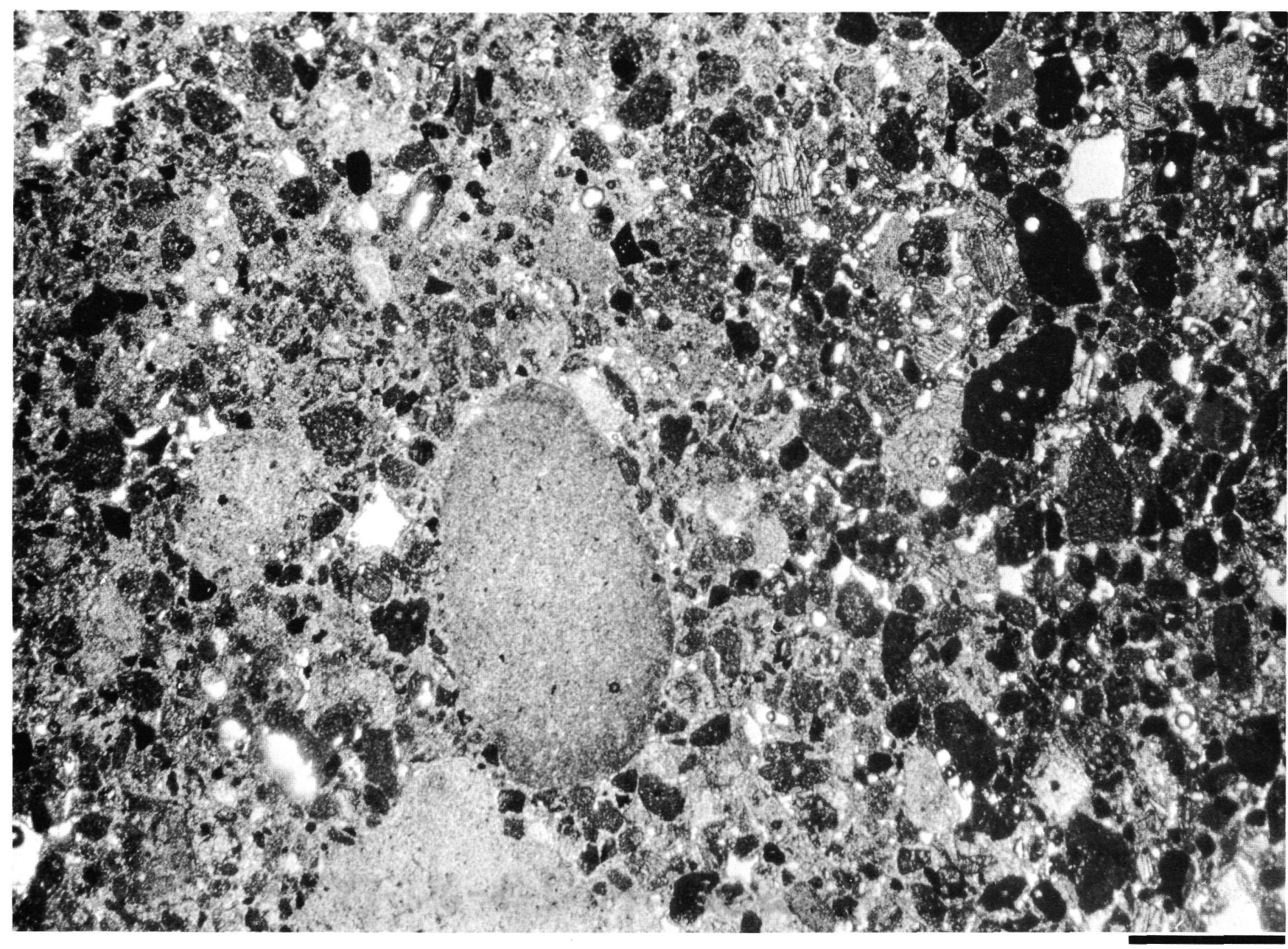

$1.0 \mathrm{~mm}$

Figure 6. Photomicrograph of a thin section (Sample 8-3,119-120 cm) of a volcaniclastic turbidite in Sub-unit 3B. Note rounded and lenticular mud clasts.

The thickest and coarsest turbidites are developed in the central part of Sub-unit 3B (middle Oligocene), and they probably record intense weathering of the Bermuda Pedestal, and possibly increased volcanism, at a time when turbidity currents had developed clear dispersal paths toward Site 386. Nonetheless, the net accumulation rate for the turbidites of Sub-unit 3B was fairly slow $(\sim 9 \mathrm{~m} / \mathrm{m} . \mathrm{y}$.; see Figure 19). The finer turbidites in the upper part of the sub-unit and the gradation to the calcareous turbidites of Sub-unit 3A suggest that denudation of Burmuda was essentially complete by late Oligocene time.

The lower boundary of Sub-unit 3B lies in the uncored interval between Cores 13 and 14 (381.5-328.0 m).

\section{Unit 4 - Siliceous and Calcareous Mudstones (318.5-328.0 to 612.9-632.0 $\mathrm{m}$ )}

Sediments of Unit 4 are represented in Core 14 to Core 34, CC. Texturally, they are claystones and siltstones, with rare intercalated sandstone layers. Because greenish gray colors prevail, the sediments are grouped into one unit, although considerable textural and compositional variations are observed within the unit. Unit
4 is subdivided into four sub-units on the basis of these parameters.

The upper part, Cores 14 to 26 , contains turbidites that have characteristic primary sedimentary structures and appear in a rhythmic sequence. In this section, two kinds of turbidites are distinguished by the composition of the coarser, basal layers. The uppermost sub-unit (4A) contains abundant siliceous ooze and is termed "siliceous turbidites." Sub-unit 4B has abundant calcareous debris in basal layers and is termed "calcareous turbidites." Further downhole the sedimentary structures typical of turbidites are no longer megascopically perceptible and claystones containing porcelanitic chert prevail (cherty claystones, Sub-unit 4C). Radiolarian mudstones (Sub-unit 4D) comprise the lowermost part of Unit 4.

\section{Sub-Unit 4A - Siliceous Turbidites}

Cores 14 through 18-3 (328.0-408.5 m) contain more than 80 meters of greenish gray clays and silts of middle Eocene age. The sediments exhibit several tens of rhythmic layers with a coarser-grained base of either medium sand or silt. According to texture 


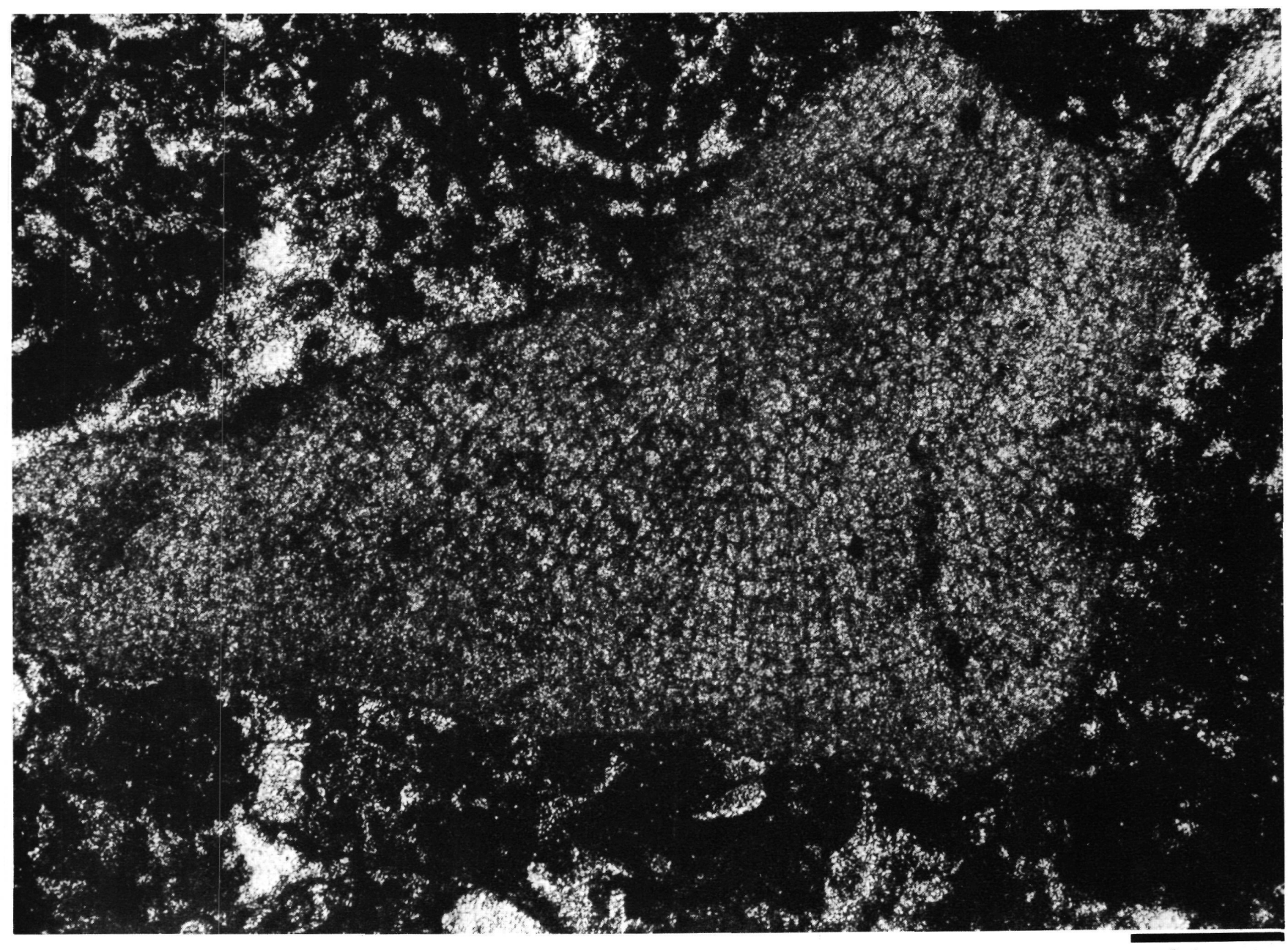

$0.1 \mathrm{~mm}$

Figure 7. Red algae fragment within heavy-mineral graded sandstone bed of Sub-unit 3B volcaniclastic turbidites. Sample 8-6, 140-142 cm; thin section.

and primary sedimentary structures, the rhythmic layers can be subdivided ideally into five sublayers, termed $\alpha, \beta, \gamma, \delta, \epsilon$, from bottom to top (Figures $8,11)$. The lowermost $\alpha$ sublayer invariably has coarser components and it is usually a medium-grained sandstone. Sorting is poor, and grading is evident in most sublayers. The overlying $\beta$-sublayer is characterized by parallel, faint laminations. This grades upward into homogeneous claystone $(\gamma)$, and mottled claystone $(\delta)$, topped by a darker, and usually much thinner sublayer in which mottling continues and is often more intense $(\epsilon)$. One or more of these sublayers may be missing, but in most cases, at least $\alpha$ and $\delta$ and a sublayer between ( $\beta$ or $\gamma$, or both) can be recognized. Thickness of an entire rhythmic layer ranges from $30 \mathrm{~cm}$ to about 3 meters. Average thickness of $\alpha$-sublayers is about 10 $\mathrm{cm}$. Colors within the $\alpha-\epsilon$ sublayers are various shades of greenish gray and green. Usually the $\gamma$ and $\delta$ sublayers are light green, and $\epsilon$ sublayers are dark green in color. The color difference is caused by varying carbonate content; the lightest colors correspond to the highest carbonate values.
The $\alpha$-sublayers contain mostly opaline silica, with a preponderance of either radiolarians or sponge spicules, but including diatoms (Figure 9); some $\alpha$-sublayers are spicule sands. Average composition of the various sublayers is given in Table 3; composition is based on examination of 41 smear slides equally distributed among sublayers, except for sublayer $\epsilon$ ( 2 slides).

Carbonate content varies within and between sublayers; data are from both shipboard and shore-lab work. In most cases, no sharp boundaries exist between the sublayers, so that carbonate values cannot always be attributed to one particular sublayer; detailed analyses were conducted on Core 15 with sampling at $10-\mathrm{cm}$ intervals, and certain trends are obvious. The $\alpha$-sublayers of Sub-unit 4A have low carbonate content (14-17\%, 2 samples), as do the $\beta$-sublayers with clearly recognizable parallel lamination $(7-17 \%$, average $12 \%, 5$ samples) and $\gamma$-sublayers (13-21\%, average 17\%, 20 samples). Much higher carbonate content occurs in the $\delta$-sublayers than in any of the other sublayers (26-56\%, average $42 \%$, 5 samples); $\epsilon$-sublayers were not analyzed for carbonate content within Sub-unit 4A, but smear slides 


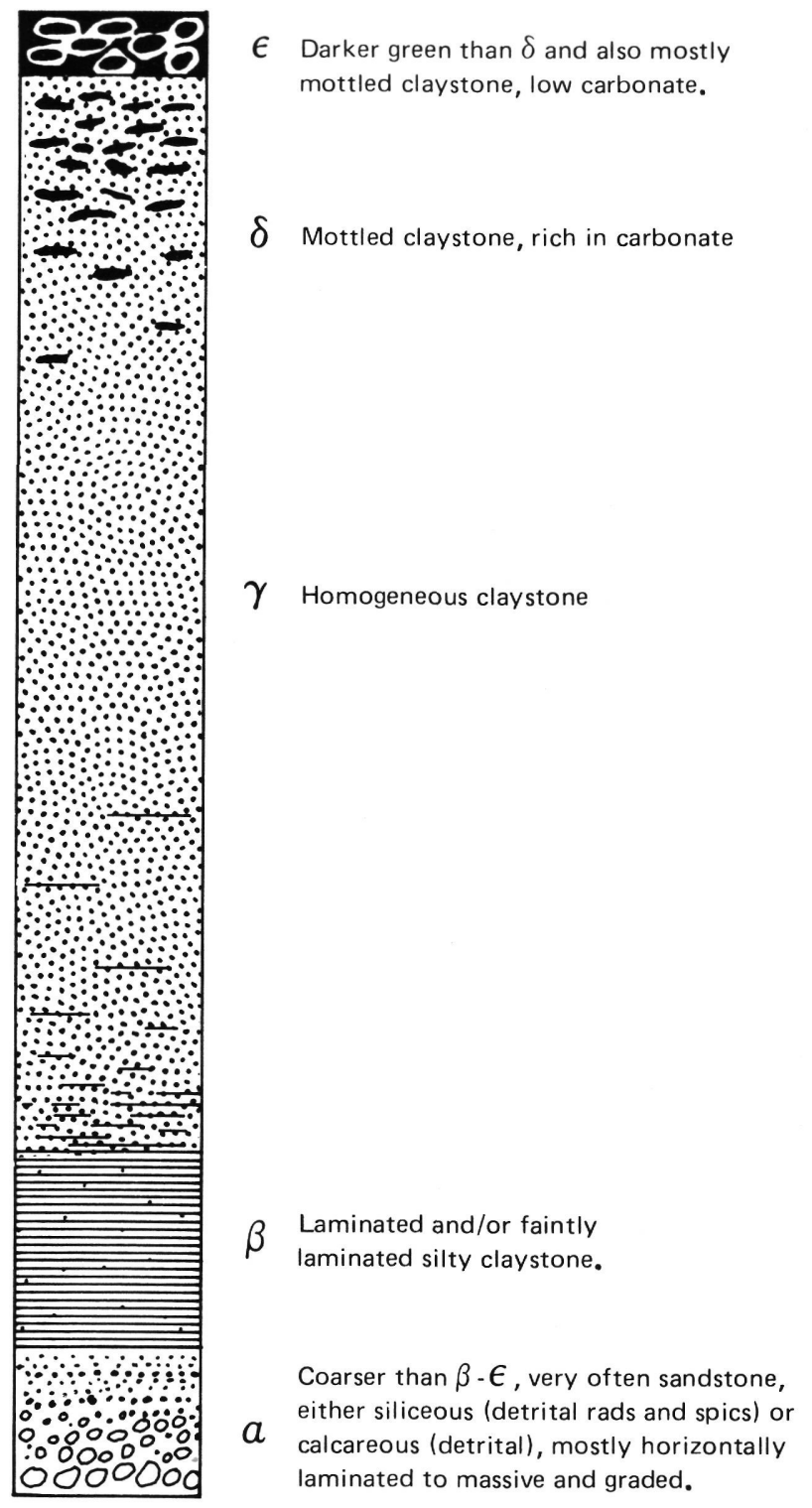

Figure 8. Idealized sequence of sublayers in turbidites of lithologic Sub-units $4 A$ and $4 B$.

indicate very little carbonate. The high carbonate content of the $\delta$ sublayers corresponds to the lightest colors in the graded unit. The carbonate is entirely low magnesian calcite and consists of nannofossils and foraminifers.

Quartz content of Sub-unit 4A is about 4 per cent and feldspar is rare. Clay minerals comprise the bulk of the non-carbonate fraction and consist of montmorillonite (average $78 \%$, range $52-88 \%, 10$ samples) and less illite (average $20 \%$, range $12-34 \%$ ).

Detailed grain-size analyses were carried out by both DSDP shore lab (Cameron, this volume) and Coultercounter methods (McCave, this volume). Standard methods show that $\alpha$ sublayers contain sand (range $0.8-27 \%, 4$ samples) and silt (range 64-74\%). $\beta$-sublayers contain up to about 40 per cent silt, and the $\gamma$ and $\delta$ sublayers are predominantly clay $(\mathbf{7 8 \%})$. This suggests grading within the $\alpha-\epsilon$ sequence but is not definitive because the samples were not taken from a single sequence. Although a sequence beginning with a sandy $\alpha$-sublayer usually has a silty $\beta$-sublayer, it is not uncommon for a silty $\alpha$-sublayer to be followed by a $\beta$-sublayer consisting mostly of clay. Coulter-counter analyses conducted on discrete sequences in Sub-unit 4A show clear grading in the $\alpha-\epsilon$ sublayers (McCave, this volume).

Organic carbon content of Sub-unit 4A is slightly higher than in the overlying Sub-unit 3B; nine analyses average $>0.3$ per cent (range $0.1-0.7 \%$ ) in $\beta, \gamma, \delta$, and $\epsilon$ sublayers. No correlation with sublayers is apparent except that the lowest values are in $\delta$ sublayers (2 analyses only).

The siliceous turbidites of Sub-unit 4A have the highest sediment accumulation rates of all units cored at Site 386 ; the average rate is $42 \mathrm{~m} / \mathrm{m}$.y. which strongly favors a turbidite origin.

In summary, Sub-unit 4A represents a rather unusual sequence of turbidites. The basal part of each turbidite $(\alpha-\gamma)$ is dominated by siliceous fossils, the $\delta$-sublayers contain more carbonate, and the $\epsilon$-sublayers are mostly clay. Reworking of pelagic sediments into the turbidites appears to be the source of these components. The high carbonate content of the $\delta$ sublayers and low carbonate in the $\epsilon$ (pelagic) sublayers favors a mechanism of redeposition of carbonate rather than pelagic deposition from the overlying surface water.

\section{Sub-Unit 4B - Calcareous Turbidites}

Cores 18-4 down through 26 contain more than 80 meters of rhythmically deposited sediments of similar aspect to Sub-unit 4A. Texture and colors are essentially the same as in Sub-unit 4A. The major difference is in the composition. Silica is virtually absent in Sub-unit 4B and is replaced by clay minerals. Thus, the carbonate contents of Sub-units 4A and 4B are generally similar. Sublayer composition calculated from 19 smear slides in 4B is given in Table 4. The upper boundary of Sub-unit $4 \mathrm{~B}$ is placed at Section 18-4 where the first calcareous $\alpha$ sublayer was observed.

Based on shipboard and shore-lab carbonate analyses, the $\alpha$ sublayers of Sub-unit 4B have an average carbonate content of 42 per cent $(11,49$, and $66 \%, 3$ samples), $\beta$ sublayers 17 per cent ( $0-25 \%, 5$ samples), $\gamma$ sublayers 25 per cent (23-27\%, 6 samples), $\delta$-sublayers 33 percent (1 sample only), and $\epsilon$ sublayers 5 per cent $(0-9 \%)$. Carbonate is entirely low magnesian calcite, mostly nannofossils with some foraminifers.

In contrast to overlying Sub-unit $4 \mathrm{~A}$ and underlying Sub-unit $4 \mathrm{C}$, quartz is common in $4 \mathrm{~B}$ (average $6 \%$, range $1-10 \%, 14$ samples) and feldspar is present in most samples (average 2\%, range 0-6\%). Sub-unit 4B also contains disordered cristobalite (average 7\%, range trace-19\%) derived from alteration of biogenic opal. The clay mineral assemblage is dominated by montmorillonite (average $77 \%$, range $60-84 \%$ ) and illite (average $22 \%$, range $16-40 \%$ ). Organic carbon is about the same as in Sub-unit 4A (average $0.4 \%$, range $0.1-1.0 \%$ ).

Accumulation rates of the calcareous turbidites are about the same as calculated for the siliceous turbidites 


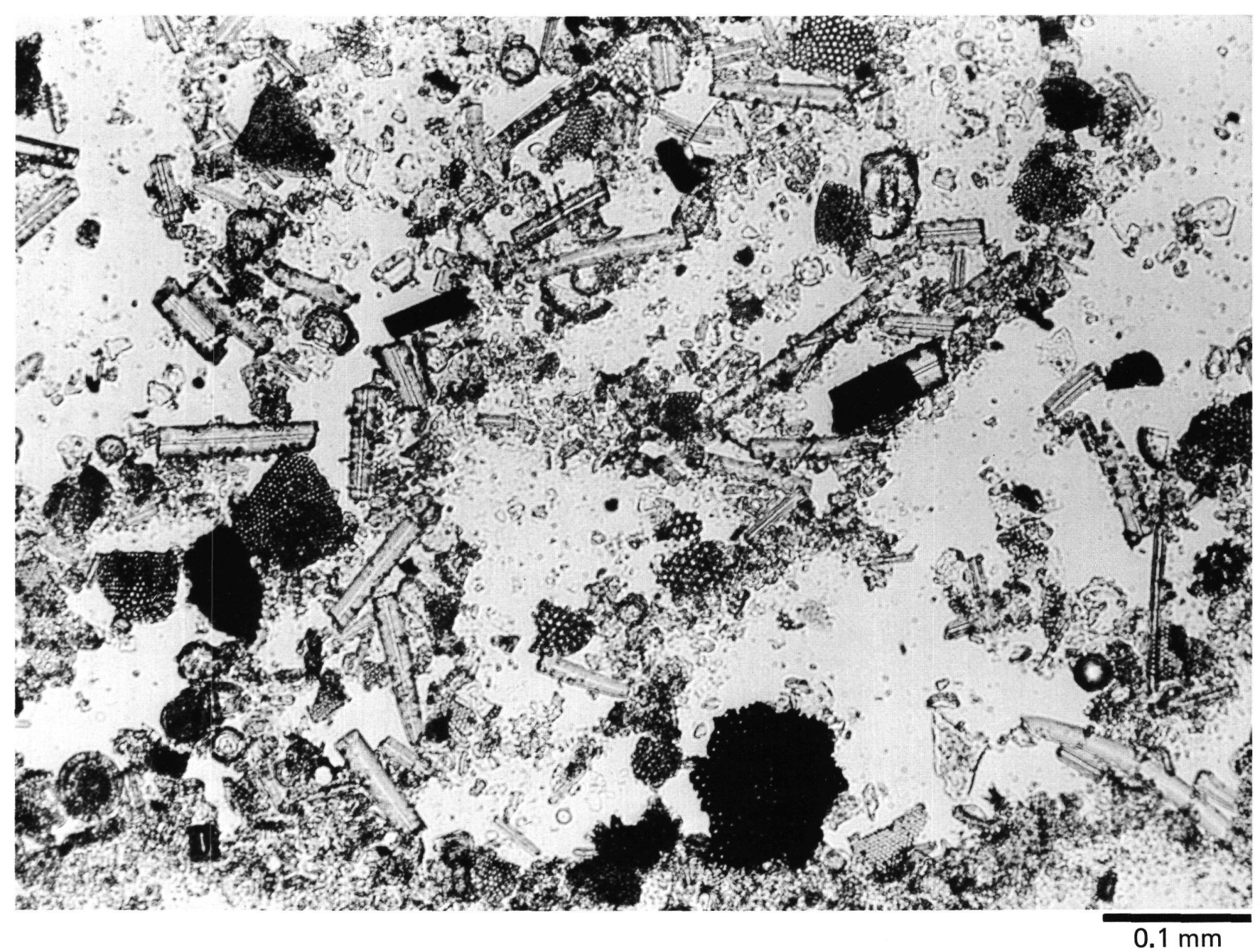

Figure 9. Sponge spicules, radiolarian fragments, and diatoms partly pyritized in the siliceous turbidites of Sub-unit $4 A$.

of Sub-unit 4A (42 m/m.y.), and similar transport and depositional mechanisms are inferred, with only a slight difference in source material. Both $4 \mathrm{~A}$ and $4 \mathrm{~B}$ turbidites were deposited during the middle Eocene, and both sequences are about 80 meters thick.

\section{Sub-Unit 4C - Cherty Claystones}

The upper boundary of Sub-unit $4 \mathrm{C}$ is placed at the level where the $\alpha-\epsilon$ sublayers are no longer readily apparent. Sub-unit $4 \mathrm{C}$ is contained in Core
27 through Core 31, Section $1,100 \mathrm{~cm}$, and is comprised of lower Eocene greenish gray claystones in various shades; some claystones are calcareous and some contain porcelanitic chert. Porcelanite mostly is restricted to mottled layers. Texture of the claystones is homogeneous, laminated, or mottled. Subunit $4 \mathrm{C}$ is partly distinguished from $4 \mathrm{~A}$ and $4 \mathrm{~B}$ by an absence of sand-sized sediments. Grain-size analysis shows about 80 per cent clay and 20 per cent silt ( 2 samples only; Cameron, this volume).

TABLE 3

Smear-Slide Composition of Turbidite Sublayers in Lithologic Sub-unit 4A

\begin{tabular}{|c|c|c|c|c|c|c|c|c|c|c|c|c|c|c|}
\hline \multirow[b]{3}{*}{ Sublayer } & \multicolumn{2}{|c|}{ Clay } & \multicolumn{6}{|c|}{ Carbonate } & \multicolumn{6}{|c|}{ Silica } \\
\hline & \multirow[b]{2}{*}{ Average } & \multirow[b]{2}{*}{ Range } & \multicolumn{2}{|c|}{ Unspec. } & \multicolumn{2}{|c|}{ Forams } & \multicolumn{2}{|c|}{ Nannos } & \multicolumn{2}{|c|}{ Radiolaria } & \multicolumn{2}{|c|}{ Diatoms } & \multicolumn{2}{|c|}{$\begin{array}{l}\text { Sponge } \\
\text { Spicules }\end{array}$} \\
\hline & & & av. & rge. & av. & rge. & av. & rge. & av. & rge. & av. & rge. & av. & rge. \\
\hline$\epsilon$ & $>95$ & $95-9$ & - & - & - & - & - & - & - & - & - & - & - & - \\
\hline$\delta$ & 37 & $10-85$ & 40 & $2-85$ & - & - & 6 & $2-10$ & 11 & $3-15$ & - & - & 3 & $0-9$ \\
\hline$\gamma$ & 41 & $29-88$ & 6 & $1-20$ & 2 & $0-13$ & 11 & $0-15$ & 33 & $0-51$ & - & - & 6 & $1-20$ \\
\hline$\beta$ & 39 & $20-80$ & 8 & $5-20$ & - & - & 10 & $3-20$ & 30 & $15-42$ & - & - & 13 & $3-40$ \\
\hline$\alpha$ & 20 & $10-35$ & 10 & $2-30$ & 8 & $2-20$ & 4 & $2-8$ & 21 & $6-50$ & 1 & & 29 & $15-45$ \\
\hline
\end{tabular}


TABLE 4

Smear-Slide Composition of Turbidite Sublayers in Lithologic Sub-unit 4B

\begin{tabular}{|c|c|c|c|c|c|c|c|c|c|c|c|c|c|c|}
\hline \multirow[b]{3}{*}{ Sublayer } & \multicolumn{2}{|c|}{ Clay } & \multicolumn{6}{|c|}{ Carbonate } & \multicolumn{6}{|c|}{ Silica } \\
\hline & \multirow[b]{2}{*}{ Average } & \multirow[b]{2}{*}{ Range } & \multicolumn{2}{|c|}{ Unspec. } & \multicolumn{2}{|c|}{ Forams } & \multicolumn{2}{|c|}{ Nannos } & \multicolumn{2}{|c|}{ Radiolaria } & \multicolumn{2}{|c|}{ Diatoms } & \multicolumn{2}{|c|}{$\begin{array}{c}\text { Sponge } \\
\text { Spicules }\end{array}$} \\
\hline & & & av. & rge. & av. & rge. & av. & rge. & av. & rge. & av. & rge. & av. & rge. \\
\hline$\epsilon$ & 97 & $95-99$ & 2 & $0-5$ & - & - & - & - & - & - & - & - & - & - \\
\hline$\delta$ & 37 & $10-89$ & 43 & $5-85$ & - & - & 1 & $0-5$ & - & - & - & - & - & - \\
\hline$\gamma$ & 82 & $77-88$ & 10 & $1-20$ & - & - & 5 & $0-10$ & - & - & - & - & 1 & $0-3$ \\
\hline$\beta$ & 76 & $72-80$ & 15 & $10-20$ & - & - & 4 & $3-5$ & - & - & - & - & - & - \\
\hline$\alpha$ & 72 & $63-80$ & 23 & $15-30$ & - & - & - & - & - & - & - & - & - & - \\
\hline
\end{tabular}

Carbonate content generally is low (range $0-7 \%, 13$ samples) except in scattered calcareous layers that contain about 30 per cent carbonate ( 3 samples). Nannofossils and unspecified carbonate comprise the calcareous fraction.

Quartz is present throughout, in about the same quantity as in Sub-unit 4B, but feldspar is restricted to the upper cores (27 and 28). Disordered cristobalite also is present throughout (average 13\%, 7 samples) and is abundant in some cores (up to 24\%). Radiolarians $(<5 \%)$ are mostly recrystallized and are the most likely source for the disordered cristobalite in this sub-unit (see Riech and von Rad, this volume). Clinoptilolite $(1-6 \%)$ was found within about half of the samples investigated; this mineral is absent within overlying Subunit 4B. The clay mineral assemblage is essentially the same as in 4B, consisting of 66 per cent montmorillonite $(54-72 \%)$ and 33 per cent illite (range 22-46\%) (Koch and Rothe, this volume). Organic carbon averages about 0.3 to 0.4 per cent (range 0.1-0.7\%, 6 samples).

Calculated accumulation rates for the cherty claystones $(20 \mathrm{~m} / \mathrm{m} . \mathrm{y}$.) are somewhat lower than those for the overlying calcareous and siliceous turbidites, but Sub-unit 4C thus may have a similar origin, that is, pelagic sediments redeposited by turbidity currents. Because of disaggregation problems in these cherty sediments, it is not possible to document suspected size grading (McCave, this volume).

\section{Sub-Unit 4D - Radiolarian Mudstones}

Core 31, Section $1,100 \mathrm{~cm}$ through Core 34, CC contain 74.5 meters of dark olive-gray radiolarian mudstone of early Eocene to late Paleocene age. The upper boundary in Core 31 is marked by a possible erosional contact that dips at $20^{\circ}$ between Sub-unit 4D radiolarian mudstones and the overlying cherty claystones. Sub-unit 4D is characterized by slightly mottled, dark olive-gray radiolarian mudstones in the upper part (about $8 \mathrm{~m}$ ) and by homogeneous to faintly laminated, thinly laminated, and mottled claystones and slightly silicified claystones (porcelanite) in the lower part. Colors within the lower part are dark greenish gray and greenish black, and dark gray within some minor very fine sandstone and siltstone laminae. Some short intervals are mottled with moderate brown colors. In the upper part of the sub-unit radiolarians are recognizable, but in the lower part (Core 34) these are mostly recrystallized.
Smear-slide estimates of the composition of the sediments are clay (average $77 \%$ range $37-90 \%, 20$ samples) and recrystallized radiolarians (about 5-11\%). In X-ray data, quartz is common $(6-15 \%$, average $10 \%)$, and feldspar is present (2-3\% on the average). Samples down through Core 33 also contain disordered cristobalite (3-13\%, average $9 \%, 4$ samples), and some clinoptilolite (trace-3\%) was found within Core 34. In contrast to the X-ray data, only small amounts of quartz were noted in the smear slides. Some of the quartz thus may be diagenetic (chalcedony), representing altered cristobalite.

The clay mineral assemblage consists of montmorillonite and illite; up to about 80 per cent of the clay fraction is montmorillonite. Average carbonate content is 14 per cent $(0-27 \%)$. Carbonate is entirely low magnesian calcite (nannofossils).

Coulter-counter analyses of the Sub-unit 4D radiolarian mudstones indicate subtle size grading which may reflect deposition of these sediments from turbidity currents (McCave, this volume).

\section{Unit 5 - Multicolored (Red) Claystones and Minor Limestone (612.9-632.0 to $724.3 \mathrm{~m})$}

Core 35 through Core 41 , Section $5,80 \mathrm{~cm}$, contain upper Maestrichtian to upper Cenomanian multicolored claystones of dominantly reddish hue, and subsidiary calcareous beds (see Figure 11). These are treated as a single unit although colors and composition suggest several lithologic variants. The Unit 5 claystones generally are rather homogeneous, but faint elongate mottles are present throughout. The contact against the overlying radiolarian mudstones of Sub-unit 4D lies in the uncored interval between Cores 34 and 35 . There is, however, a marked color change between the two units, from dark greenish gray (Sub-unit 4D) to dusky dark red and grayish red (Unit 5). The upper part (Cores 35 and 36) of Unit 5 has two distinct lithofacies, the principal one being red claystone, sensu stricto. In smear slides, quartz was observed only in trace quantities, but in X-ray data ( 3 samples) it constitutes 14 per cent of the sediment; this "quartz" may include chalcedony altered from biogenic opal. Feldspar is about 4 per cent. The clay minerals include mica/illite (average $52 \%$, range $50-57 \%$ ), montmorillonite (average $31 \%$, range $28-35 \%$ ), kaolinite (average $11 \%$, range $10-12 \%$ ), and chlorite (average 6\%, range 4-10\%). Virtually no kaolinite or chlorite are present immediately below and 
above this uppermost member of Unit 5. The illite within this upper member is well crystallized and is considered a detrital component. Further downhole, wellcrystallized illite was not found (see below). While the montmorillonite within the overlying Sub-unit 4D has a well-developed $17 \AA$ reflection, in this upper member of Unit 5 it has a broad reflection at about $14 \AA$ that represents mixed-layer montmorillonite/illite. Smear slides always showed at least trace amounts of Fe/Mn-oxides, and at the top of the unit some micronodules $1-3 \mathrm{~mm}$ in diameter were found. The organic carbon content is 0.1 per cent or less ( 3 samples). Carbonate content is nil except for the bed noted below.

A 2.3-meter-thick bed of limestone and marly limestone of light greenish gray, light bluish gray, and white color is present in Core 35 (Section 4, $16 \mathrm{~cm}$, to Section $5,95 \mathrm{~cm}$ ) (see Figure 11). It is partly laminated to crosslaminated and is of late and middle Maestrichtian age. Carbonate content is 57 and $\mathbf{6 3}$ per cent in two samples; most of this is recrystallized calcite with minor nannofossils. An X-ray sample in a marly interbed (35-5, 0-3 cm) contains 11 per cent carbonate and the same proportions of mineral components as the surrounding claystones; about half of the carbonate is dolomite and this is the shallowest occurrence of dolomite in the hole.

The middle part of Unit 5 (Cores 38 through 40) consists of 28.6 meters of claystones which are easily distinguished from the over- and underlying sediments by their color (dusky yellowish brown banded with moderate brown). The claystones are thinly and irregularly laminated throughout (see Figure 11). They grade downward into mostly red claystones (Core 39) with a few light greenish gray "bleached" horizons usually 1 $\mathrm{cm}$ or less in thickness. Sediments of this middle member contain no fossils and are undated. Mineralogy of these claystones is markedly different from those immediately above. Quartz, feldspar, and total clay minerals are present in about the same proportions, but abundant clinoptilolite $(6-18 \%$, average $11 \%, 6$ samples) and 1-2 per cent of phillipsite justifies the term "zeolitic claystones" for this middle member. Disordered cristobalite (2-10\%, average 5\%, 6 samples) within Unit 5 is also restricted to this member. The clay mineral assemblage is dominated by montmorillonite (average $56 \%$, range $39-83 \%$ ) and illite (average $41 \%$, range $17-61 \%$ ), with only rare kaolinite and chlorite. The montmorillonite is not well crystallized but has a clear $17 \AA$ peak. The peak is very broad and suggests authigenic formation from volcanic glass which smear slides indicate is abundant. This is also indicated in the diffractograms by a background bulge caused by abundant amorphous material. Illite also has broad reflections and may be diagenetically altered from montmorillonite. The total carbonate content within the middle member is near zero $(<1 \%)$.

Of six organic carbon samples from this unit, only one sample contained detectable carbon $(0.1 \%)$.

The lower part of Unit 5 (Core 41 , top, to $41-5,80 \mathrm{~cm}$ ) consists of dark reddish brown claystone with local bands of dark greenish gray. One X-ray sample indicates high quartz ( $28 \%$, not noted in smear slides) 70 per cent clay minerals, and absence of zeolites and cristobalite. Total carbonate is zero. Clay minerals are 73 per cent montmorillonite, 19 per cent illite, and minor kaolinite and chlorite. Organic carbon is 0.0-0.1 per cent (2 samples).

The red clays of Unit 5 clearly were deposited below the CCD, except for the middle and upper Maestrichtian marly limestone bed in Core 35. A sharp middlelate Maestrichtian depression and rise of the CCD is almost certain (see Figure 11); wherever sediments of this age have been cored in the deeper basin of the western North Atlantic (Sites 10, 384, 385, 386, 387), they are highly calcareous (see Tucholke and Vogt, this volume). The red claystones in Unit 5 accumulated at slow, typically pelagic rates of about $2 \mathrm{~m} / \mathrm{m}$.y.

\section{Unit 6 - Dark Greenish Gray and Black Claystone With Radiolarian Sand Beds (724.3 to $964.2 \mathrm{~m}$ )}

This lowermost sedimentary unit at Site 386 is 239.9 meters thick and is contained within Cores 41 , Section 5 , $80 \mathrm{~cm}$ to $65, \mathrm{CC}$. Core 66 recovered basalt (see below). In terms of thickness, Unit 6 is the most important of the site. Bedding planes in the sediment dip $5^{\circ}-10^{\circ}$, locally $15^{\circ}$, and towards the bottom of the hole $15^{\circ}-20^{\circ}$. This dip may not be hole deviation, but rather true dip caused by differential compaction beside the steep basalt scarp near the site (see Figure 21). The sediments are essentially claystones and mudstones, some of which are rich in organic matter; marly chalk and radiolarian sand layers are scattered throughout (see Figure 11).

Colors are predominantly dark greenish gray and black, indicating a dominantly reducing depositional environment. Within Core 46 and at the bottom of Core 45 , however, red shades reappear. Some minor reducing pulses were also observed within the overlying Unit 5, in Core 41 . Thus the colors indicate a transitional contact between Units 5 and 6 . The upper boundary of Unit 6 was picked at Core 41 , Section $5,80 \mathrm{~cm}$, because further downhole, red colors indicative of an oxygenated depositional environment are very scarce, and radiolarian sand layers become abundant.

The age of Unit 6 is upper Cenomanian to lower Albian, based on often poorly preserved nannoplankton and foraminifers (see Biostratigraphy).

Black colors prevail from Core 43 to uppermost Core 44, they become less important between Cores 44 and 49 , and they again are abundant in Core 49 and the top of Core 50 and from the base of Core 54 to Core 65 . Black beds generally contain abundant radiolarian sand layers (Cores 43-45, 58-65), and most are at least faintly laminated, whereas the interbedded greenish gray claystones usually are mottled.

Carbonate content varies considerably within Unit 6 . Shipboard carbonate-bomb determinations gave an average of 37 per cent $(0-75 \%, 42$ samples) but this is a biased sample of intervals where smear slides already had suggested high carbonate. Random sampling for shore-lab processing gives an average of $18 \%(0-66 \%$, 48 samples) which is a more realistic average. Random $\mathrm{X}$-ray-mineralogy samples also were tested and gave an average of 22 per cent $(0-80 \%, 55$ samples). The high 
carbonate contents are concentrated within layers of marly chalk and calcareous claystones. Some thin marly chalk layers with nannofossils and radiolarians are present within Core 45, but calcareous sediments (both marly chalk and calcareous claystones) become an important part of the sediments only below Core 47. They are light gray, yellowish gray, and greenish gray down to Core 51 but change to various shades of gray and olive-gray from Core 52 downward. Thin whitish laminae of nannofossil chalk are intercalated near the base of Unit 6.

Most of the carbonate is low magnesian calcite from nannofossils, but below Core 50, calcite with higher amounts of magnesium (8-10 mole $\% \mathrm{MgCO}_{3}$, highmagnesian calcite), Ca-dolomite (rare), dolomite, mangano-calcite, siderite (Figure 10), and rhodochrosite were found. Both siderite and rhodochrosite are locally concentrated in layers up to a few $\mathrm{cm}$ thick, and they also form concretions in Cores 62, 63, and 64 .

Quartz is abundant in X-ray diffraction samples $(0-80 \%$, average $30 \%, 55$ samples $)$ and high silica percentages $(75 \%, 71.5 \%)$ also were found locally by XRF (see Murdmaa et al., this volume). However, almost no detrital quartz was detected in smear slides. It seems probable that most of the "quartz" is chalcedony that has been diagenetically transformed from original biogenic opal via an intermediate stage of disordered cristobalite. This inference agrees with studies by Berger and von Rad (1972), who found that with increasing depth and age, opal and lussatite (disordered cristobalite) are finally transformed into quartzitic rock (see also Riech and von Rad, this volume).

Feldspar is present in minor amounts in about half of the cores (average less than $1 \%$, range $0-4 \%$ ). The clay mineral assemblage is dominated by montmorillonite in the upper part and by illite in the lower part of Unit 6 with a transitional zone where both clay minerals are present in about equal amounts. The upper part (Cores 41 through 51) has an average of 71 per cent montmorillonite (range $53-80 \%, 18$ samples) and 29 per cent illite (range 20-47\%). The transitional zone (Cores 52 through 54) has 49 per cent montmorillonite (range 38 to $65 \%$, 6 samples) and 51 per cent illite (range 35-62\%). The lower part (below Core 54) contains an average of 10 per cent montmorillonite (range $0-41 \%$, 22 samples) and 88 per cent illite (range 59-100\%).

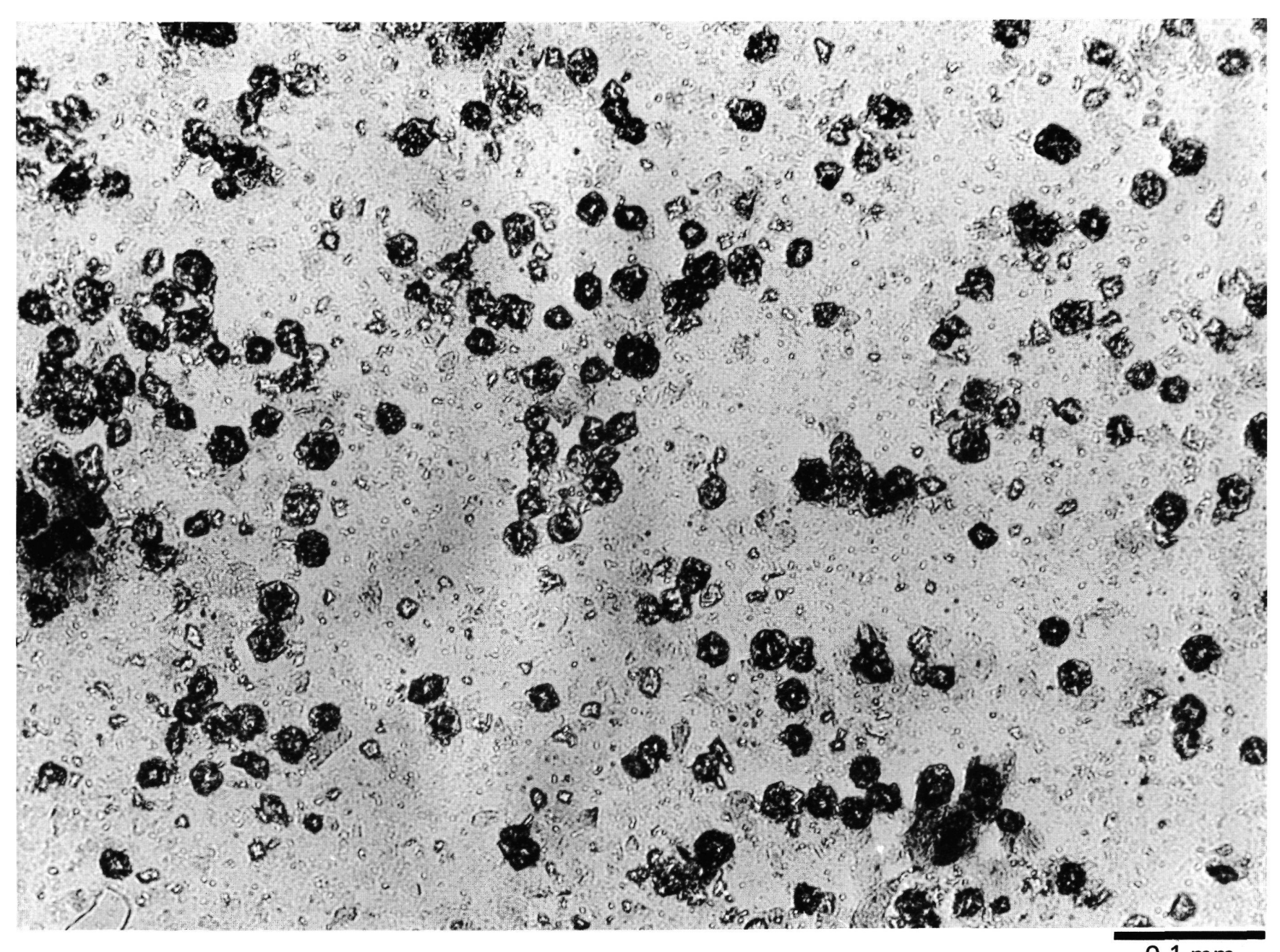

$0.1 \mathrm{~mm}$

Figure 10. Siderite within claystones of lithologic Unit 6. Sample 46-2, $77 \mathrm{~cm}$; smear slide. 
Below Core 57 montmorillonite is scarce and occurs only in a few samples. The ratio of montmorillonite to illite within Unit 6 thus decreases almost continuously from about 4 at the top of the unit to near 0 within Cores 58 through 65 (Koch and Rothe, this volume). Transformation of montmorillonite into illite by uptake of potassium and possibly compaction may account for this change.

Pyrite is present in most cores of Unit 6 and is concentrated in black layers of both clay and radiolarian sand. Traces to a few percent of disseminated pyrite dust indicated in smear slides probably are responsible for the prevailing dark to black colors. Some thin layers and lenses are rich in pyrite (up to $40 \%$ in X-ray data); locally large concretions also occur and a single concretion $4.5 \times 6.5 \mathrm{~cm}$ in size was recovered in Core 44 , Section 1, 82-86 cm (Figure 11).

Barite was found within a few samples only. In Core 64, Section 5, 113-115 cm, abundant barite (30\%) occurs together with siderite and rhodochrosite. Some phosphatic material was suggested from smear slides; it occurs within carbonate-rich sediments forming yellowish gray to very light gray layers of less than one to several $\mathrm{cm}$ thick. Apatite (about 3\%) was found by X-ray analysis within Core 63, Section 3, 146-147 cm.

Organic carbon is locally enriched in the sediments of Unit 6, in strong contrast to samples from Units 1 through 5 , which average about 0.1 per cent, and rarely reach 1.0 per cent. In Unit 6 , the average is higher $(1.4 \%, 48$ samples), and a maximum value of 11.5 per cent was determined in Core 43 , Section $2,135 \mathrm{~cm}$. The organic carbon consists of both detrital carbon recycled from continental areas and marine carbon (Kendrick, this volume). The intra-unit distribution shows that the highest values occur near the top and the base of Unit 6 . This is similar to the distribution of the amount of black coloration in the unit, and it also corresponds to frequency of radiolarian sand layers (McCave, this volume). However, there is no direct correlation between the blackness of a given sedimentary layer and its organic carbon content (Kendrick, this volume).

Sedimentation rates of $\sim 16 \mathrm{~m} / \mathrm{m} . \mathrm{y}$. were calculated for Unit 6 on the basis of paleontological data. This is a mean, and within the 240-meter-thick unit several fluctuations in sediment input are likely to have occurred (see also McCave, this volume).

The primary sedimentary structures of Unit 6 include parallel and irregular lamination, and homogeneous to burrow-mottled claystones are common. Laminations are most common within the darker grayish black and black beds, and irregular laminations and burrow mottles appear in beds of grayish blue-green to greenish color. Size grading determined by Coulter-counter analysis exists in Sections 44-4 and 62-4 (McCave, this volume), and it suggests that turbidites with cryptic grading may be common in the unit. From Core 60 downhole, small graded beds can be visually observed; some have flat, mostly green mud clasts at the base. The frequent radiolarian sand layers ( 0.5 to $>3 \mathrm{~cm}$ thick) intercalated in the claystones of Unit 6 are not graded and generally have sharp upper and lower boundaries parallel to the bedding (Figure 11). Some of them, however, have irregular upper boundaries (Cores 64 and 65) and some also contain very small mud clasts which makes reworking of pelagic sediments and redeposition by turbidity currents a likely source. McCave (this volume) also has suggested that deposition of the radiolarian sand beds may have occurred during "long blooms."

The contact of sedimentary Unit 6 with basaltic basement was probably lost in Core 66, Section 1, which recovered 1.9 meters of basalt. The lowermost sediments recovered are greenish black and grayish black mottled claystones $(65, \mathrm{CC})$ overlying dark gray and black claystones with sandstone layers consisting mostly of recrystallized radiolarians. The lowermost sandy layers contain poorly sorted mud clasts with lesser unspecified carbonate and pyrite. The deepest layer also contained grains of green chlorite.

\section{Discussion}

Nannofossils recovered in Core 65, Section 1, indicate the sedimentary history at Site 386 began during early Albian time. The site was drilled within a fracture valley between adjacent topographic highs and about $100 \mathrm{~km}$ southeast of the Bermuda Pedestal. The site consequently exhibits a sedimentary record dominated by locally derived turbidites. The lowermost sedimentary unit (6) is characterized by gray-green and black colors and by fairly high sedimentation rates (16 $\mathrm{m} / \mathrm{m} . \mathrm{y}$.$) . Abundance of pyrite, siderite, rhodochrosite,$ and preservation of rather high amounts of organic matter within this unit clearly reflect a reducing depositional environment.

There are two possible explanations of such conditions: (1) the "stagnant basin model" wherein anoxic bottom water is assumed, and (2) the "reducingsediment model" wherein high productivity supplies organic carbon to the sediments faster than it can be oxidized, thus creating reducing conditions within the sediment column even though the bottom water may be oxygenated.

Kendrick (this volume) presents geochemical evidence that bottom waters must have been at least sporadically anoxic; total sulfur content in the sediment commonly exceeds that which could have been derived from sulfate in the interstitial water, and reduction of sulfate from the overlying bottom water thus seems to be required. On the other hand, some sediments indicate oxygenated bottom water because they are burrow mottled; most of these burrowed sediments are the interbedded gray-green clays, although rare black layers are also burrowed. These latter sediments must have experienced internal microreducing conditions because they contain abundant pyrite.

Rapid sediment emplacement which might have aided in development of internal microreducing conditions is demonstrated by the relatively high sedimentation rates and by beds of apparent turbidite origin. Local turbidity currents originating on adjacent basement highs probably account for the pelagic detritus in these turbidites; 


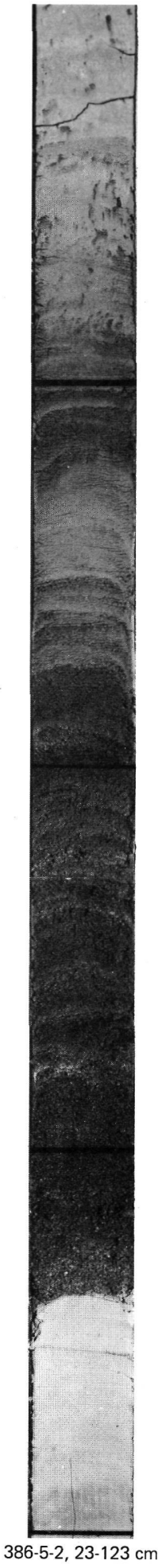

a

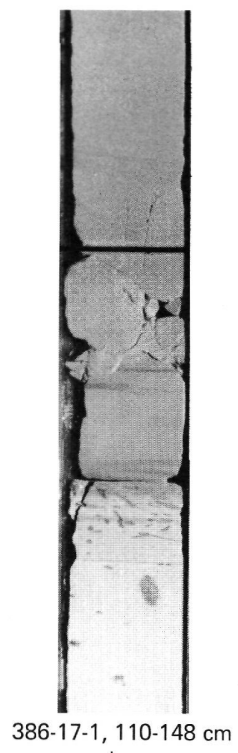

b

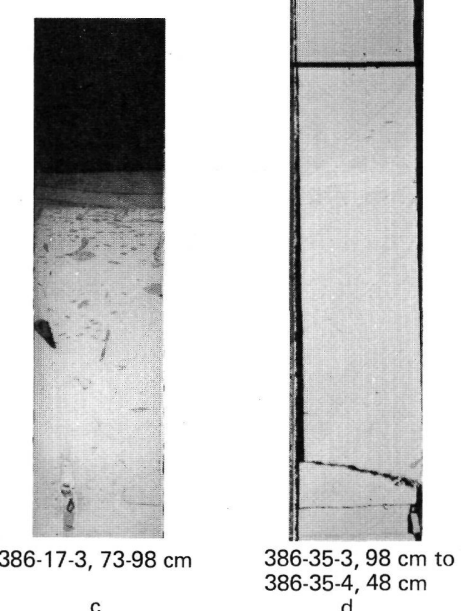

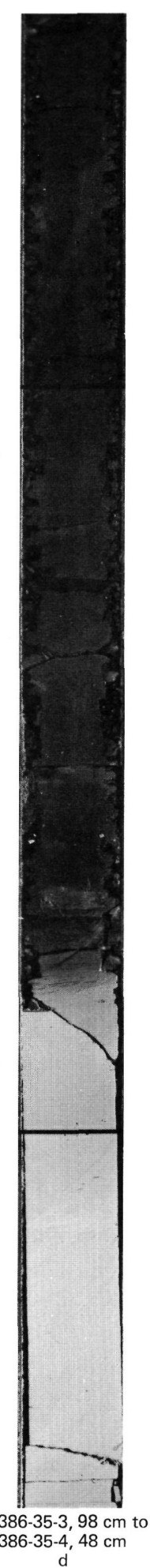
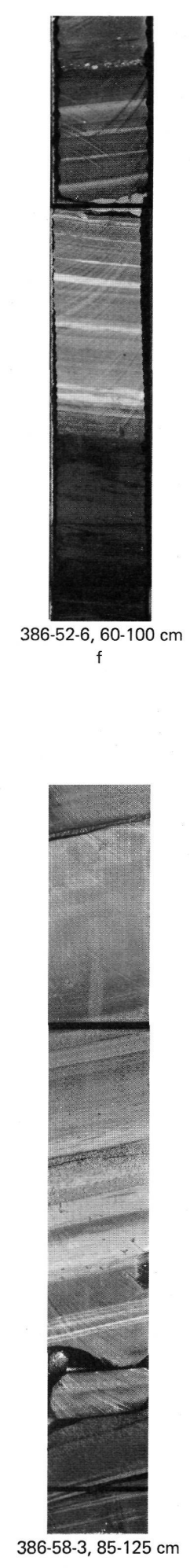

Figure 11. Examples of lithofacies at Site 386. (a) Volcaniclastic turbidites in lithologic Sub-unit 3B. (b) Sublayers in siliceous turbidites (Sub-unit 4A); from bottom; $\gamma$ (light, carbonate-rich), $\delta$ (light, mottled), $\epsilon$ (thin, darker, mottled), with overlying a, $\beta$ (coarser, graded, laminated). (c) Sublayers in siliceous turbidites (Sub-unit 4A); from bottom; $\gamma$ (light, carbonate-rich), $\delta$ (light, mottled), $\epsilon$ (darker, low carbonate), with overlying $\beta$ (dark, faintly laminated). (d) Reddish carbonate-free claystones overlying marly limestones in lithologic Unit 5; note sharpness of contact. (e) Zeolitic multicolored claystones of Unit 5. (f) Gray-green and black claystones and marly chalk in Unit 6; note marly clasts at $64 \mathrm{~cm}$ and radiolarian sand at $88 \mathrm{~cm}$. (g) Black claystones in Unit 6; note radiolarian sand beds at 87, 105, and $119 \mathrm{~cm}$. 
just $6 \mathrm{~km}$ southwest of Site 386, a basement peak rises more than 1800 meters above the level of basement at the site.

The Unit 6 sediments clearly are the lateral equivalent of the black clays previously drilled at Sites 5, 101, and 105. Site 386 exhibits a double peak of organic carbon richness at the top and the base of Unit 6. This was also reported from Site 105. However, this organic carbon distribution is not so clearly demonstrated in the compressed section at Site 387 (see Site 387 Report). The oldest sediments cored at Site 386 have mineralogy striking similarly to that at Sites 101 and 105 . The presence of siderite, pyrite, and rhodochrosite at these sites is characteristic of formation within a reducing environment.

The carbonate-rich cycles with Unit 6 are best explained by deposition of calcareous turbidites derived from the adjacent basement highs. The sea floor at Site 386 was probably below the contemporary CCD, but the adjacent peaks were above the CCD (Tucholke and Vogt, this volume).

The bottom water became predominantly oxygenated in the late Cenomanian, as indicated by the termination of black clay deposition. However, minor black clay beds continued to be deposited into the base of Unit 5, and they suggest continuing minor anoxic episodes.

After an interval of pelagic red clay deposition below the CCD, a remarkable section of volcanogenic banded clays was deposited. The sharp upper contact of the banded clays against sediments which contain almost no zeolites suggests that a period of volcanic activity was centered in the late Cenomanian. A possible source of the volcanic components is early Bermudan volcanism; Reynolds and Aumento (1974) obtained a 91 m.y.B.P. radiometric date on pillow lavas drilled beneath Bermuda in Deep Drill 1972. There seems to be little doubt that the abundant zeolites (mostly clinoptilolite), montmorillonite, and poorly crystallized illite within these clays were derived from the alteration of volcanic ash. The igneous record on Bermuda, however, is one essentially of basaltic volcanism whereas formation of clinoptilolite requires higher amounts of silica (Hay, 1966). The additional silica may have been provided by biogenic opal; some chalcedony spherules and disordered cristobalite within the banded clays suggest that biogenic opal was once present.

The thin bed of limestone in Unit 5 indicates a sharp but temporary depression of the CCD during the middle and late Maestrichtian. This observation is substantiated by similar occurrences of calcareous beds at Sites 385 and 387.

During the early Tertiary (late Paleocene through early Eocene) accumulation of low-carbonate radiolarian mudstones indicates that Site $\mathbf{3 8 6}$ was again below the CCD. Mean sedimentation rates increased rapidly during this period to a maximum of about 42 $\mathrm{m} / \mathrm{m} . \mathrm{y}$. in the early and middle Eocene. Although the upper Paleocene through lower Eocene sediments visually appear to be fine grained, Coulter-counter analyses of the sediments (McCave, this volume) indicate graded intervals are common and the sediments are probably turbidites. The sediments contain mostly siliceous pelagic components and may be "pelagic turbidites" derived from adjacent bathymetric highs (Lancelot et al., 1972).

During the middle Eocene, sedimentation was dominated by somewhat coarser turbidites which can be megascopically recognized. The coarser grained basal layers of the turbidites often contain calcareous material probably of shallow water origin. The highest carbonate contents are found in the fine-grained upper (homogeneous) parts of the turbidites and the carbonate is mostly reworked nannoplankton. Siliceous debris including sponge spicules, radiolarians, and diatoms, dominate the basal layers of turbidites higher in the sequence, and flattened mudclasts are abundant in some of these layers. The topmost layers of these turbidites are nearly carbonate-free, and they are burrow mottled, indicating that the bottom water was oxygenated. The low carbonate contents of the pelagic (burrowed) members of the Eocene turbidites and higher carbonate in lower members (graded to laminated) indicates that most carbonate was reworked from shallower areas and redeposited below the CCD at Site 386

Similar middle Eocene biogenic turbidites were reported from Sites 6, 7, and 8 (Ewing et al., 1969; Beall and Fischer, 1969; Peterson et al., 1970). These turbidites and those of Site 386 contain recrystallized silica forming porcelanitic cherts in the upper lower to lower middle Eocene section (Riech and von Rad, this volume). Unfortunately, recovery of the Eocene turbidites and cherts at Sites 6,7 , and 8 was very poor and probably sediments corresponding only to the uppermost turbidites at Site 386 were recovered. Similar turbidites also are observed at Site 387 on the western Bermuda Rise, and these are thought to be derived from the continental margin of North America; whether these turbidites reached as far as Site $\mathbf{3 8 6}$ on the central Bermuda Rise is uncertain.

The upper Eocene through upper Oligocene section at Site 386 contains turbidites with abundant volcanogenic material concentrated mostly in the basal sand layers. These sediments contain a rich suite of heavy minerals and detrital zeolites derived from weathering of the Bermuda Pedestal. The continuity of this volcaniclastic unit (Horizon $A^{v}$ ) with the Bermuda Pedestal in seismic profiles clearly demonstrates the Bermudan provenance (Tucholke, this volume), as does analysis of the heavy-mineral composition (Galehouse, this volume). The absence of polymineralic clasts in the turbidites indicates strong weathering of the source rocks at or above sea level before discharge into the deep sea. The age of these turbidites agrees with independent evidence from "Deep Drill 1972" on Bermuda (Reynolds and Aumento, 1974) in establishing the most recent Bermudan volcanism as late Eocene to Oligocene.

At the beginning of the early Miocene a gradational change of lithology towards turbidites with basal layers rich in carbonate (including shallow-water skeletals) is observed. This is interpreted to be the result of erosion of the Bermudan volcanics to wave base and establishment of carbonate accretion on the pedestal. Although 
the shallow-water debris in some turbidites indicates Bermudan provenance, other carbonate turbidites were probably derived from local bathymetric highs. Relative carbonate abundance in the lower Miocene sediments, as compared with the underlying Oligocene section, can be attributed to the diminution of the rapidly deposited volcaniclastic turbidites which previously had diluted the carbonate.

The upper Miocene to Recent sedimentary record is dominated by hemipelagic clays deposited mostly below the CCD. Occasional carbonate-rich layers are probably derived from adjacent topographic highs. Quaternary nannofossil ooze indicates recent depression of the CCD below 4700 meters.

\section{Basalt}

Based on an examination of drilling rates, it appears that basaltic basement at Site $\mathbf{3 8 6}$ was reached at a subbottom depth of 966.2 meters. The drill penetrated about 9.6 meters of igneous basement, of which 1.9 meters of basalt were recovered (Sections 66-1, 66-2, 66, CC). The sediment in immediate contact with the basalt and possibly more weathered, surface basalt were not recovered.

\section{Megascopic and Petrographic Description}

The deepest sediment recovered (Core 65; $964.2 \mathrm{~m}$ sub-bottom) consists of a greenish black claystone dated on the basis of nannofossils as early Albian (105-108 m.y.). Within the claystone are two 5 -cm-thick beds of coarse, unsorted, blue-green silty claystone containing small clasts of highly altered basalt. The upper bed at 963.8 meters (Sample 65-3, 135-140 cm) contains subrounded to angular elongate clasts of carbonate, claystone, and altered basalt up to $2 \mathrm{~mm}$ in mean diameter. A second bed at 963.9 meters (Sample 65-3, 145-150 cm) is of similar composition; however, clasts tend to be sand sized. Basaltic clasts in both layers are extensively chloritized. One extremely altered plagioclase lath with a composition similar to that in the underlying basalt (An 65) was found in the upper bed. The similarity between these beds and the blue-green silty claystone recovered immediately above basalt at Site 384 suggests that both may have been formed by weathering of basalt.

Basement rock (Unit 7) recovered in this hole is a hypocrystalline, fine-grained, amygdaloidal phyric basalt characterized by a groundmass of randomly oriented plagioclase microlites with intergranular pyroxene. Phenocryst phases consist of common subhedral prismatic plagioclase (0.097-0.87 mm; An 65 to 70) and rare, corroded, subangular pyroxene crystals (0.54-1.4 $\mathrm{mm}$.). Plagioclase phenocrysts are usually turbid from the effects of minor alteration and may show the development of sericite, montmorillonite, and/or other clay minerals. Pyroxene phenocrysts display variable optic angle but always less than $30^{\circ}$ and positive, suggesting compositions between pigeonite and sub-calcic augite. Phenocrysts all show optical strain and incomplete extinction; rarely these combine to suggest an hour-glass pattern. Signs of resorption of early pyrox- ene phenocrysts, suggested by their corroded nature, are masked by extensive alteration to montmorillonite and chlorite.

The groundmass consists mainly of a complex network of plagioclase laths (An 67) with interstitial granular pyroxene and lesser relict glass, locally subophitic in fabric. Alteration has preferentially affected the glass and fine groundmass and left the phenocrysts relatively fresh. All glass grains tend to be partially to wholly devitrified, and most are extensively altered to chlorite. Angular interstitial areas and small rounded pools of green montmorillonite and chlorite mark the sites of former glass and pyroxene. Remnant pyroxene grains appear to be compositionally similar to the phenocryst phase. Occasional disseminated magnetite also appears as skeletal crystals in the groundmass. The freshest samples display a feathery texture in the groundmass, reminiscent of a feather duster, in which small microlites of plagioclase radiate from one end of a slightly larger plagioclase lath. True feather and plumose groundmass textures, as described by Bryan (1972) from Site 105, were not found. Amygdules of calcite and/or montmorillonite account for less than 1 to 3 per cent of the cross-sectional area. Calcite stringers up to $0.04 \mathrm{~mm}$ wide are common. Average mineralogical composition for this basalt is given in Table 5 .

Between 966.3 and 967.0 meters sub-bottom depth, the basalt is intersected by a segregation of calcite interpreted as a hydrothermal vein (Figure 12). The calcite is lightly to extensively speckled by enclosures of green chlorite and very altered clasts of basalt. Orientation of clasts suggests flow lineation within the vein pipe. Except for rare instances, even the phenocrysts in these clasts are altered beyond recognition, making the enclosures appear totally structureless. Although the center of the vein is almost pure calcite, chlorite is the dominant constituent of its upper and lower margin. The vein is variously bounded by dense, slickensided, lamellar coatings of chlorite and rarely serpentine, and by sharp irregular contacts with the basalt (Figure 13). The latter, along with the large quantity of chlorite and basalt clasts in the vein, suggests some assimilation of wallrock material by the hydrothermal fluids as they were intruded along a fault or joint. The ease with which chlorite slickensides may be formed suggests that little relative movement of the fault blocks was involved. A few enclosures of devitrified selvege, identified by their shape, attest to an original pillow struc-

TABLE 5

Average Mineralogical Composition of Basalts Recovered at Site 386

\begin{tabular}{lcc}
\hline Mineral & Range (\%) & Average (\%) \\
\hline Plagioclase & $50-60$ & 57 \\
Pyroxene & $25-35$ & 30 \\
Glass & $1-2$ & 1 \\
Magnetite & $2-5$ & 3 \\
Chlorite & $5-15$ & 8 \\
Calcite & $1^{+}$ & 1 \\
Serpentine & $0-1$ & trace \\
\hline
\end{tabular}




\section{6}

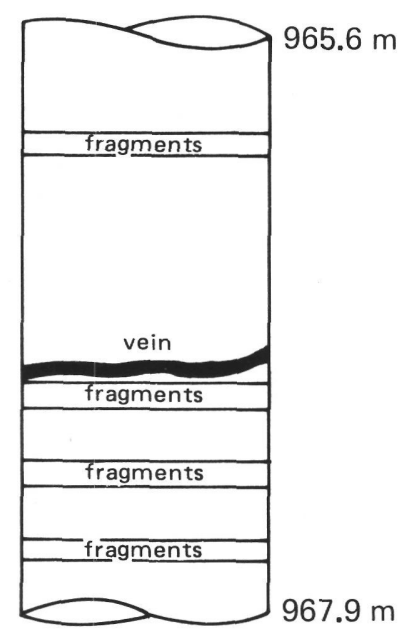

Figure 12. Basement stratigraphy at Site 386; calcite vein shown in black.

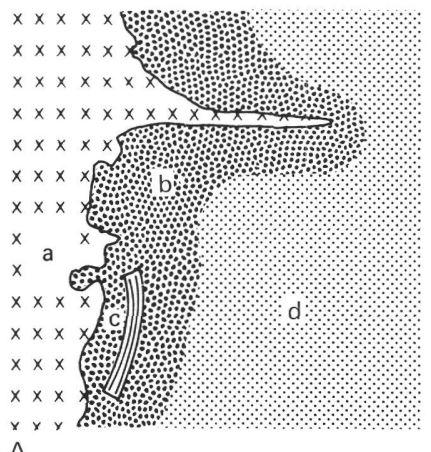

A

Figure 13. Typical margins of the hydrothermal calcite segregation in contact with the basalt wall rock. (A) Sharp, irregular contact showing selvage in a halo of chlorite associated with partial assimilation of the wallrock by the vein. (B) Calcite vein bounded by dense, slickensided, lamellar coating of chlorite with rare serpentine. $a=$ basalt $; b=$ calcite segregation with dense inclusions of chlorite from the alteration of the wallrock; $c=$ selvage clast torn from the wallrock and preferentially aligned along the flow direction of the hydrothermal fluids within the vein; $d=$ calcite vein with minor chlorite and basaltic clasts; $e=$ slickensided, lamellar coatings of chlorite with minor serpentine.

ture in the basalt. Basalt immediately adjacent to the vein displays an ordered alteration halo based upon the intensity of chloritization. Up to $1 \mathrm{~cm}$ away from the hydrothermal vein, almost all of the basalt groundmass is chloritized. For another $2 \mathrm{~cm}$, all vesicles are filled with chlorite instead of calcite. Beyond $3 \mathrm{~cm}$ from the vein, only the matrix pyroxene and glass show extensive alteration.

Basalt recovered beneath the vein bore bright yellow native sulfur stains. This sulfur could have originated during the hydrothermal event, but no sulfide minerals were found associated with the vein. Reduction of seawater sulfate, possibly at elevated temperatures in the hydrothermal vein, is a plausible alternate mode of origin.

The freshest basalt was recovered from the lowest part of the core, nominally at 973.8 meters depth.

\section{Discussion}

Basement rocks of Site 386 are moderately chloritized basalts. The absence of olivine, the presence of pigeonitic augite, and enrichment in groundmass iron as indicated by late crystallized magnetite suggest a nearly saturated or oversaturated subalkaline basalt. A hydrothermal vein $7 \mathrm{~cm}$ thick cuts the cored interval. The basalt is comparable to that found at Site 100 and typifies present-day ridge basalt.

\section{GEOCHEMICAL MEASUREMENTS}

\section{Carbon, Nitrogen}

The results of the shipboard organic carbon and nitrogen analyses are summarized in Table 6, and the carbon values together with additional shore-lab analyses are shown in Figure 14. The organic carbon contents of the sediments in the upper 720 meters of Site 386 (lithologic Units 1-5) are generally less than $0.5 \%$.

TABLE 6

Shipboard Organic Carbon, Nitrogen Measurements, ${ }^{\mathrm{a}}$ Site 386

\begin{tabular}{lrrrr}
\hline $\begin{array}{c}\text { Sample } \\
\text { Interval in cm) }\end{array}$ & $\begin{array}{c}\text { Depth Below } \\
\text { Sea Floor }(\mathrm{m})\end{array}$ & $\begin{array}{l}\text { \% } \mathrm{C}_{\text {org }} \\
\text { In } \mathrm{N}\end{array}$ & $\frac{\mathrm{C}}{\mathrm{N}}$ \\
\hline $1-5,130$ & 59.9 & $<0.1$ & 0.01 & - \\
$4-5,130$ & 154.5 & 0.1 & 0.03 & 3 \\
$11-2,150$ & 254.9 & $<0.1$ & $<0.01$ & - \\
$13-2,150$ & 312.0 & 0.1 & 0.03 & 3 \\
$15-4,130$ & 352.7 & 0.3 & 0.04 & 8 \\
$17-3,32-33$ & 389.8 & 0.2 & 0.03 & 7 \\
$17-3,60-61$ & 390.1 & 0.7 & 0.06 & 12 \\
$18-5,130$ & 411.3 & 0.2 & 0.02 & 10 \\
$22-4,130$ & 447.9 & 0.3 & 0.03 & 10 \\
$27-1,150$ & 491.3 & 0.3 & 0.03 & 10 \\
$31-3,150$ & 541.9 & 0.3 & 0.03 & 10 \\
$33-1,150$ & 576.7 & 0.1 & 0.01 & 10 \\
$36-3,150$ & 646.0 & 0.1 & 0.03 & 3 \\
$38-4,150$ & 694.9 & $<0.1$ & 0.02 & - \\
$41-5,14$ & 723.6 & 4.6 & 0.23 & 20 \\
$42-3,130$ & 731.3 & 0.3 & 0.01 & 30 \\
$43-3,130$ & 740.6 & 7.7 & 0.31 & 25 \\
$44-3,150$ & 750.1 & 1.9 & 0.10 & 19 \\
$45-0,20$ & 765.0 & 0.5 & 0.02 & 25 \\
$47-6,0$ & 781.9 & 0.5 & 0.02 & 25 \\
$48-3,130$ & 797.6 & 0.4 & 0.02 & 20 \\
$51-1,130$ & 823.2 & 0.4 & 0.02 & 20 \\
$54-5,150$ & 857.9 & 0.4 & 0.01 & 40 \\
$56-3,150$ & 873.9 & 0.9 & 0.04 & 23 \\
$57-3,150$ & 883.4 & 0.6 & 0.02 & 30 \\
$60-5,130$ & 914.5 & 2.4 & 0.12 & 20 \\
$63-1,130$ & 937.1 & 4.0 & 0.23 & 20 \\
\hline
\end{tabular}

aAditional shore-lab data are given by Kendrick (this volume) and Cameron (this volume). 


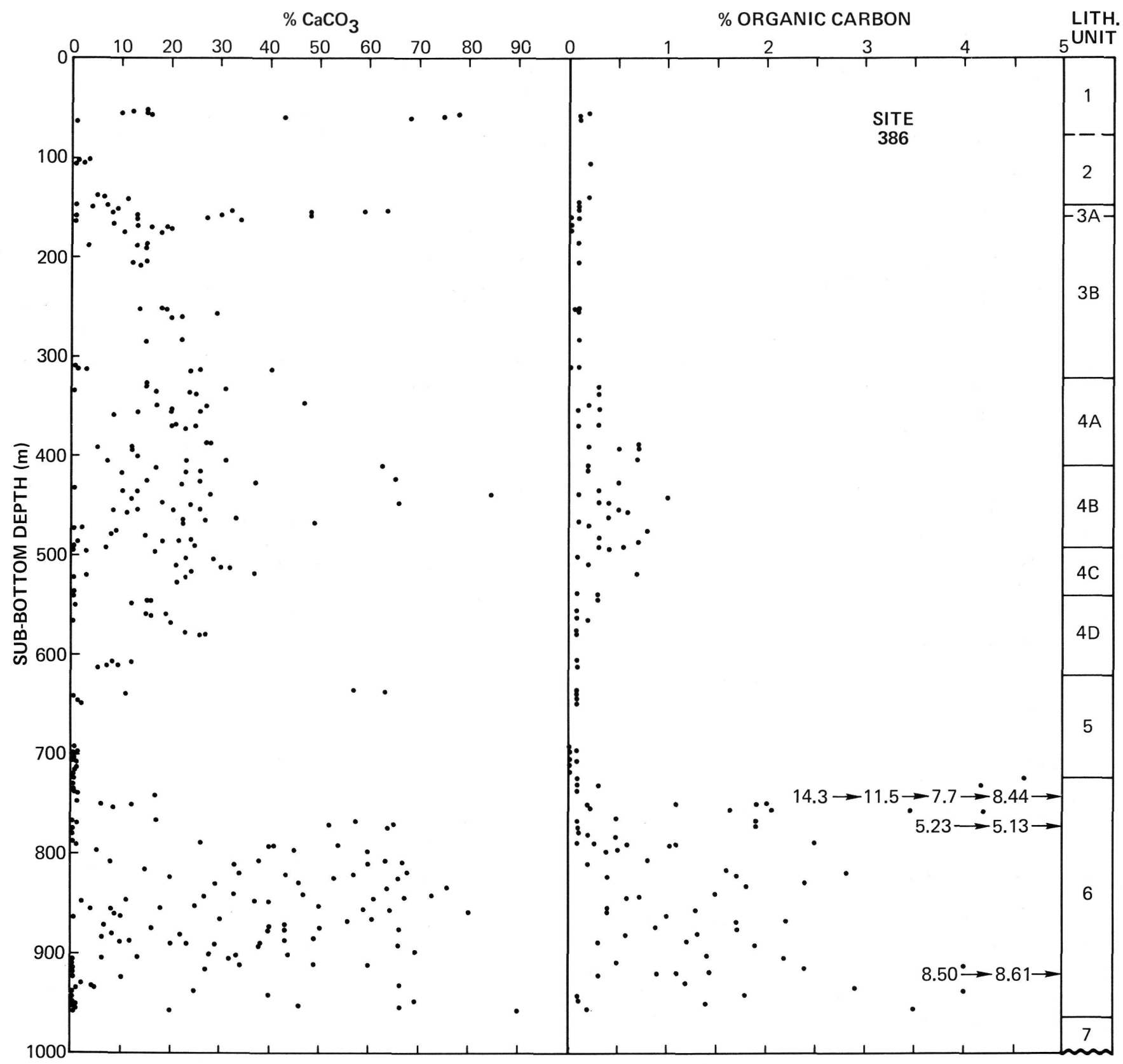

Figure 14. $\mathrm{C}_{\mathrm{org}}$ and $\mathrm{CaCO}_{3}$ at Site 386. Based on data from shipboard analyses (Tables 6 and 7), and from Kendrick; Koch and Rothe; and Cameron (all in this volume).

In contrast, the organic carbon contents of the underlying black and greenish gray claystones (Unit 6) are often much higher, reaching values as high as $14.3 \%$.

The apparent distribution of organic matter within Unit 6 is interesting. Although the sequence of black and greenish gray clays is 240 meters thick, high organic carbon values are confined to the upper $\mathbf{4 0}$ meters and lower 60 meters of the interval. The intervening sediments have comparatively low organic carbon contents.

Pyrolysis fluorescence (PF) measurements support the trends in organic carbon content observed in conventional analyses (Figure 15). Both PF and conventional analyses indicate that the black clays between 720 and 760 meters are very rich in organic matter. The organic carbon contents of the underlying sediments are lower, averaging about $0.6 \%$ around 800 meters and increasing gradually with depth to average values of $1.7 \%$ near the base of Unit 6 . Similarly, PF values at intermediate depths in the black claystone sequence $(760-900 \mathrm{~m})$ are frequently zero, whereas the sediments below 900 meters commonly have PF values of several hundred units.

It is difficult to determine whether the variations in the abundance of organic matter at Site $\mathbf{3 8 6}$ are significant on a regional scale. The black clay sequences at other sites in the northwestern Atlantic (e.g., Sites 105 


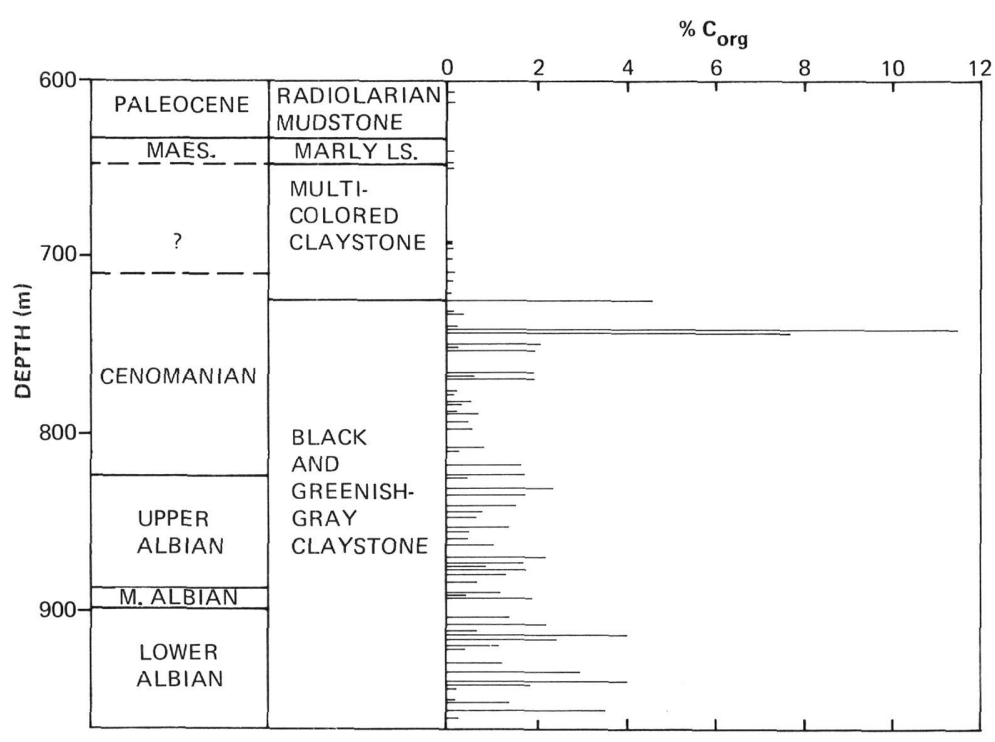

Figure 15. Pyrolysis fluorescence (PF) measurements of organic richness in sediments at Site 386. PF is a method for estimating the amount of organic matter by measuring (in arbitrary PF units) the amount of fluorescing bitumen generated by heating the sample.

and 387) are not as thick or as well dated as at Site 386, making comparison difficult. At each site, however, high organic carbon values are found near the top of the black clay sequence, suggesting that differences in the concentration of organic matter may be correlative.

While the shallow sediments (Units 1 to 5) at Site 386 display $\mathrm{C} / \mathrm{N}$ ratios of 12 or less, the black and greenish gray clays have values of 20 to 30 . As noted in previous site summary chapters (Sites 382 and 385 ), a significant fraction of the nitrogen in sediments containing small amounts of organic matter may be inorganic nitrogen, associated with clay minerals (Stevenson and Cheng, 1972). The fact that several samples in the black clay interval display high $\mathrm{C} / \mathrm{N}$ ratios while containing moderately low amounts of organic matter (0.3-0.5\%) implies that such values more accurately reflect the carbon and nitrogen composition of organic matter in the sediments. Indeed, the $\mathrm{C} / \mathrm{N}$ ratios of kerogens isolated from black claystones range from 25 to 35 (Kendrick, this volume). It is not readily apparent, however, that $\mathrm{C} / \mathrm{N}$ ratios can be related to other compositional parameters of the organic matter.

\section{Calcium Carbonate}

The shipboard values of $\mathrm{CaCO}_{3}$ obtained using the carbonate bomb (Müller and Gastner, 1972) are tabulated in Table 7 and are summarized together with shore lab data in Figure 14. The carbonate content of the sediments at Site 386 is quite variable, ranging from zero in the red claystones (Unit 5) to 90 per cent in portions of the black and greenish gray clays (Unit 6). Most of the sediments at Site 386, however, contain between 10 and 40 per cent $\mathrm{CaCO}_{3}$.

The high calcium carbonate contents in Unit 6 probably reflect episodic deposition by turbidites of pelagic carbonates that accumulated on adjacent bathymetric highs. A similar origin of clearly turbiditic carbonates is probable in lithologic Units 1 through 4.

\section{Interstitial Water Chemistry}

Interstitial water samples were taken at Site 386 to a depth of 715 meters; below this depth water could no longer be squeezed from the sediments. The results of the chemical analyses are summarized in Table 8 and Figure 16.

The concentration of dissolved magnesium decreases substantially in the upper 350 meters of Site 386 while the concentration of dissolved calcium increases over the same depth range. Below 350 meters the trends in calcium and magnesium concentration reverse slightly before stabilizing below 475 meters.

The anomalously low salinities and chlorinities at 480 and 613 meters probably reflect fresh-water contamination during squeezing (Miller and Gieskes, this volume). There is a general decrease in salinity with depth, however, which is real and probably reflects removal of sulfate from the interstitial water (Miller and Gieskes, this volume).

\section{PHYSICAL PROPERTIES}

Undrained shear strength, thermal conductivity, compressional wave velocity, wet bulk density, and water content measurements were made on sediment and rock samples recovered at Site 386 . These data are presented in Table 9, and the test methods are listed in the Physical Properties section of the Site 382 Report. Sediment test specimens typically are taken from the lower, least-disturbed sections of each core. As a check on the variation of properties within a core, two water content and two shear strength measurements were made in each 
TABLE 7

Shipboard $\mathrm{CaCO}_{3}$ Measurements, ${ }^{\mathrm{a}}$ Site 386

\begin{tabular}{|c|c|c|}
\hline $\begin{array}{c}\text { Sample } \\
\text { (Interval in } \mathrm{cm} \text { ) }\end{array}$ & $\begin{array}{l}\text { Depth Below } \\
\text { Sea Floor (m) }\end{array}$ & $\% \mathrm{CaCO}_{3}$ \\
\hline $1-2,75-76$ & 54.9 & 15 \\
\hline $1-3,110-111$ & 56.7 & 78 \\
\hline $1-5,90-91$ & 59.5 & 75 \\
\hline $1-6,75-76$ & 60.9 & 1 \\
\hline $2-5,100-101$ & 107.1 & 0 \\
\hline $3-1,115-116$ & 139.2 & 5 \\
\hline $4-2,75-76$ & 149.5 & 4 \\
\hline $4-4,75-76$ & 152.5 & 9 \\
\hline $4-5,93-94$ & 154.1 & 48 \\
\hline $4-6,4-5$ & 154.7 & 8 \\
\hline $4-6,35-36$ & 155.1 & 59 \\
\hline $4-6,73-74$ & 155.4 & 48 \\
\hline $5-3,75-76$ & 160.6 & 27. \\
\hline $5-4,6-8$ & 161.4 & 34 \\
\hline $6-2,90-91$ & 168.7 & 13 \\
\hline $6-3,75-76$ & 170.1 & 20 \\
\hline $7-1,42-43$ & 176.2 & 18 \\
\hline $8-1,142-143$ & 186.7 & 15 \\
\hline $8-2,88-89$ & 187.7 & 3 \\
\hline $9-2,108-109$ & 206.9 & 15 \\
\hline $11-1,93-94$ & 252.8 & 18 \\
\hline $12-2,102-103$ & 282.9 & 22 \\
\hline $12-4,117-118$ & 286.1 & 20 \\
\hline $13-3,70-71$ & 312.7 & 0 \\
\hline $13-3,137-138$ & 313.4 & 40 \\
\hline $13-3,148-149$ & 313.5 & 24 \\
\hline $14-2,24-25$ & 329.7 & 15 \\
\hline $14-4,99-100$ & 333.5 & 31 \\
\hline $14-4,100-101$ & 333.5 & 0 \\
\hline $14-6,106-107$ & 336.6 & 24 \\
\hline $15-1,5-6$ & 347.0 & 47 \\
\hline $15-5,35-36$ & 353.3 & 20 \\
\hline $16-3,38-39$ & 369.4 & 21 \\
\hline $16-5,81-82$ & 372.8 & 23 \\
\hline $17-2,80-81$ & 387.3 & 27 \\
\hline $17-5,53-54$ & 391.5 & 12 \\
\hline $18-1,75-76$ & 404.8 & 23 \\
\hline $18-4,80-82$ & 409.3 & 63 \\
\hline $18-6,34-35$ & 411.8 & 17 \\
\hline $19-2,89-90$ & 416.0 & 10 \\
\hline $20-1,64-66$ & 423.8 & 65 \\
\hline $20-2,67-68$ & 425.3 & 15 \\
\hline $20-3,5-6$ & 426.2 & 37 \\
\hline $21-2,106-108$ & 435.3 & 0 \\
\hline $21-5,10-12$ & 438.8 & 28 \\
\hline $22-4,36-40$ & 447.0 & 18 \\
\hline $23-2,44-48$ & 453.7 & 21 \\
\hline $23-4,16-17$ & 456.4 & 8 \\
\hline $24-2,22-25$ & 462.9 & 22 \\
\hline $24-4,133-136$ & 467.0 & 22 \\
\hline $25-1,51-55$ & 471.3 & 0 \\
\hline $25-5,140-142$ & 478.2 & 15 \\
\hline $26-2,133-135$ & 483.1 & 18 \\
\hline $26-5,88-89$ & 487.2 & 0 \\
\hline $27-2,105-106$ & 492.4 & 0 \\
\hline $27-4,94-95$ & 495.2 & 17 \\
\hline $28-2,79-80$ & 501.7 & 23 \\
\hline $29-2,60-61$ & 511.0 & 21 \\
\hline $29-5,70-71$ & 515.6 & 24 \\
\hline $29-5,124-125$ & 516.1 & 37 \\
\hline
\end{tabular}

TABLE 7 - Continued

\begin{tabular}{|c|c|c|}
\hline $\begin{array}{c}\text { Sample } \\
\text { (Interval in } \mathrm{cm} \text { ) }\end{array}$ & $\begin{array}{l}\text { Depth Below } \\
\text { Sea Floor (m) }\end{array}$ & $\% \mathrm{CaCO}_{3}$ \\
\hline $30-2,90-91$ & 520.8 & 0 \\
\hline $30-3,74-75$ & 521.1 & 23 \\
\hline $30-6,54-55$ & 526.4 & 21 \\
\hline $31-1,30-31$ & 537.7 & 0 \\
\hline $31-6,100-102$ & 545.9 & 12 \\
\hline $31-6,146-147$ & 546.4 & 12 \\
\hline $32-2,106-107$ & 558.8 & 15 \\
\hline $33-2,67-68$ & 577.4 & 23 \\
\hline $34-2,89-90$ & 606.1 & 8 \\
\hline $34-6,75-76$ & 612.0 & 7 \\
\hline $35-4,46-47$ & 637.0 & 57 \\
\hline $36-3,75-76$ & 645.3 & 0 \\
\hline $36-5,83-84$ & 648.3 & 0 \\
\hline $36-5,136-137$ & 648.9 & 0 \\
\hline $38-2,61-62$ & 691.0 & 0 \\
\hline $38-6,63-65$ & 697.0 & 0 \\
\hline $39-1,33-34$ & 698.8 & 0 \\
\hline $40-3,105-106$ & 712.1 & 0 \\
\hline $41-1,119-121$ & 718.7 & 0 \\
\hline $41-4,0-1$ & 722.0 & 0 \\
\hline $42-4,53-54$ & 732.0 & 0 \\
\hline $44-2,77-78$ & 748.1 & 6 \\
\hline $44-4,61-66$ & 750.9 & 8 \\
\hline $45-2,44-45$ & 766.7 & 0 \\
\hline $45-3,64-65$ & 768.4 & 57 \\
\hline $45-5,147-148$ & 772.3 & 64 \\
\hline $46-2,42-44$ & 776.3 & 0 \\
\hline $46-5,53-57$ & 781.0 & 0 \\
\hline $47-3,72-73$ & 787.5 & 26 \\
\hline $47-5,51-52$ & 790.3 & 54 \\
\hline $47-6,91-92$ & 792.2 & 40 \\
\hline $48-2,116-117$ & 796.0 & 60 \\
\hline $49-3,141-142$ & 807.2 & 67 \\
\hline $49-4,31-32$ & 807.6 & 38 \\
\hline $50-5,73-74$ & 819.0 & 34 \\
\hline $50-5,103-105$ & 819.3 & 68 \\
\hline $51-1,34-36$ & 822.3 & 53 \\
\hline $51-1,75-77$ & 822.7 & 68 \\
\hline $51-3,142-143$ & 826.3 & 46 \\
\hline $52-2,77-79$ & 833.7 & 63 \\
\hline $52-6,72-73$ & 839.6 & 73 \\
\hline $53-1,80-81$ & 841.7 & 27 \\
\hline $53-2,114-115$ & 843.5 & 67 \\
\hline $53-4,11-12$ & 845.5 & 37 \\
\hline $54-1,97-98$ & 851.4 & 50 \\
\hline $54-2,40-41$ & 852.3 & 18 \\
\hline $54-2,140-141$ & 853.3 & 8 \\
\hline $54-3,122-123$ & 854.6 & 59 \\
\hline $54-4,52-53$ & 855.4 & 76 \\
\hline $54-6 \quad 99-100$ & 858.9 & 6 \\
\hline $55-2,15-16$ & 861.6 & 0 \\
\hline $55-3,70-71$ & 863.6 & 61 \\
\hline $55-5,114-115$ & 867.0 & 10 \\
\hline $56-4,78-79$ & 874.6 & 50 \\
\hline $56-5,114-115$ & 876.4 & 40 \\
\hline $57-6,31-32$ & 886.7 & 49 \\
\hline $57-6,107-108$ & 887.5 & 12 \\
\hline $57-6,114-115$ & 887.5 & 38 \\
\hline $58-1,101-102$ & 889.3 & 29 \\
\hline $58-2,116-117$ & 891.0 & 28 \\
\hline $59-1,50-51$ & 898.2 & 69 \\
\hline $59-3,65-66$ & 901.4 & 28 \\
\hline
\end{tabular}


TABLE 7 - Continued

\begin{tabular}{lcc}
\hline $\begin{array}{c}\text { Sample } \\
\text { (Interval in cm) }\end{array}$ & $\begin{array}{c}\text { Depth Below } \\
\text { Sea Floor }(\mathrm{m})\end{array}$ & $\% \mathrm{CaCO}_{3}$ \\
\hline $59-5,122-123$ & 904.9 & 13 \\
$60-2,47-49$ & 909.2 & 0 \\
$60-3,119-120$ & 911.4 & 49 \\
$60-5,93-95$ & 914.1 & 0 \\
$60-6,68-70$ & 915.4 & 27 \\
$61-4,81-82$ & 922.1 & 0 \\
$61-5,78-79$ & 923.6 & 10 \\
$62-4,140-141$ & 932.2 & 4 \\
$62-6,22-23$ & 934.0 & 5 \\
$63-2,10-12$ & 937.4 & 25 \\
$63-4,10-11$ & 940.4 & 0 \\
$64-2,31-32$ & 947.1 & 0 \\
$64-3,1-2$ & 948.3 & 69 \\
$65-1,28-29$ & 955.1 & 0 \\
$65-1,114-115$ & 955.9 & 90 \\
\hline
\end{tabular}

${ }^{\mathrm{a} C a r b o n a t e}$ bomb method. Additional shorelab data are given by Koch and Rothe (this volume).

of the five sections recovered in Core 1 and specimens from upper sections of other cores were tested periodically. Since chalk and rock specimens are generally intact and undisturbed, they were selected randomly from core sections.

\section{Shear Strength}

Coring was intermittent in the upper 170 meters of sediment and there is limited strength data (Figure 17). These data also are erratic because of sample disturbance and the variable sediment types encountered. As an example, the top four sections of Core 1 contain a nannofossil ooze whereas the fifth and final section contains stiffer brown clay. The nannofossil ooze exhibits an anomalously low shear strength that increases with depth in core. The low shear strengths imply extreme disturbance and/or addition of water during the coring process. The brown clays sampled in Cores 1,4 , and 5 were visibly sound, with little distortion, and they ex- hibit the expected increase in strength with sub-bottom depth. However, some specimens below about 150 meters fractured upon vane insertion, thus preventing testing, and other specimens appeared to fracture prematurely along bedding planes with rotation of the vane; this may explain the data scatter at about 150 meters. Shear strength tests were therefore terminated at 165 meters.

\section{Water Content}

Figure 18 graphically summarizes the water content data for Site 386. Most of the low water content values correspond to layers of cemented sandstone, siltstone, and limestone. There appear to be three basic sequences characterized by similar physical characteristics above basement at 964 meters. The upper sequence includes the sediments of lithologic Units 1 through 4A. Water content values are scattered in these variable lithofacies, especially in the volcaniclastic sandstones in Sub-unit 3B. Generally, water content decreases only slightly with sub-bottom depth as a result of compaction, and it averages about 40 per cent by wet weight exclusive of the sandstone beds. The second sequence contains calcareous turbidites, cherty claystones, radiolarian mudstones, and multicolored claystones down to about 724 meters sub-bottom (Units 4B through 5). The water contents again are scattered, but they are much lower than in overlying sediments, averaging about 25 per cent. The basal sequence is composed predominantly of black and gray layered claystone from 724 meters to 964 meters (Unit 6). The water contents are about 19 per cent, and they exhibit little variation. The water content differences between these sequences can be explained by varying degrees of consolidation, by mineralogical/ compositional differences, and by diagenetic effects due to aging and burial.

Water content data in the nannofossil oozes of Core 1 show, as at Site 384, that 10 per cent or more water is being added to the upper core sections compared to lower core sections during the coring process. For clays and claystone in the upper 200 meters, water

TABLE 8

Interstitial Water Chemistry, Site 386

\begin{tabular}{cccccccc}
\hline $\begin{array}{c}\text { Sample } \\
\text { (Interval in cm) }\end{array}$ & $\begin{array}{c}\text { Depth Below } \\
\text { Sea Floor }(\mathrm{m})\end{array}$ & $p \mathrm{H}$ & $\begin{array}{c}\text { Alkalinity } \\
(\mathrm{meq} / \mathrm{l})\end{array}$ & $\begin{array}{c}\text { Salinity } \\
(\% \circ \mathrm{o})\end{array}$ & $\begin{array}{c}\text { Chlorinity } \\
(\% \circ)\end{array}$ & $\begin{array}{c}\mathrm{Ca}^{++} \\
(\mathrm{m} \text { mole/1) }\end{array}$ & $\begin{array}{c}\mathrm{Mg}^{++} \\
(\mathrm{m} \mathrm{mole} / \mathrm{l})\end{array}$ \\
\hline Surface seawater & - & 8.72 & 2.46 & 36.3 & 20.2 & 10.8 & 54.9 \\
$1-4,144-150$ & 58.6 & 8.02 & 2.70 & 34.9 & 19.3 & 10.8 & 51.1 \\
$4-4,144-150$ & 153.2 & 7.86 & 1.19 & 35.2 & 19.4 & 32.6 & 28.4 \\
$7-2,140-150$ & 178.8 & 8.45 & 0.54 & 35.2 & 19.9 & 33.5 & 24.9 \\
$11-1,140-150$ & 253.4 & 8.48 & 0.49 & 35.2 & 20.0 & 40.1 & 18.6 \\
$14-5,144-150$ & 335.5 & 7.78 & 0.59 & 34.9 & 19.7 & 48.4 & 12.3 \\
$15-5,140-150$ & 354.4 & 7.82 & 1.14 & 34.6 & 19.7 & 46.0 & 13.5 \\
$17-5,140-150$ & 392.5 & 7.87 & 2.28 & 34.6 & 19.6 & 46.6 & 15.0 \\
$25-1,140-150$ & 472.3 & - & 1.70 & 31.1 & 18.2 & 35.1 & 21.0 \\
$29-3,140-150$ & 513.4 & - & 1.00 & 33.0 & 19.0 & 31.2 & 27.0 \\
$31-4,140-150$ & 543.4 & - & 1.10 & 33.3 & 19.5 & 36.0 & 23.6 \\
$34-5,140-150$ & 611.2 & - & - & 31.1 & 18.2 & 32.4 & 22.2 \\
$36-4,140-150$ & 647.5 & - & 2.10 & 33.0 & 19.5 & 36.4 & 28.3 \\
$40-2,140-150$ & 711.0 & - & 1.40 & 33.0 & 19.3 & 35.9 & 25.6 \\
\hline
\end{tabular}




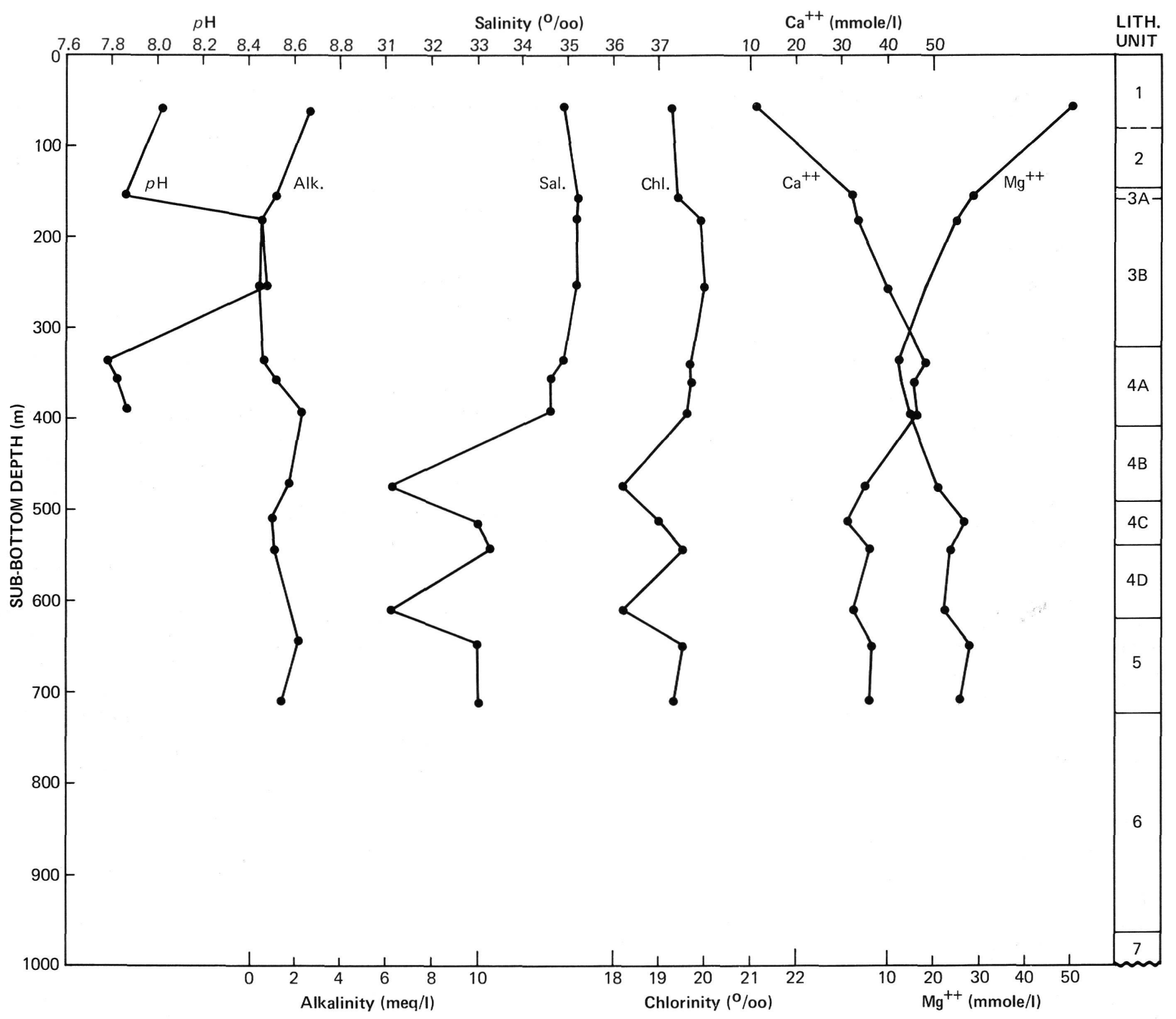

Figure 16. Interstitial water chemistry versus depth, Site 386.

col tents from adjacent core sections suggest a similar $t \ldots$.. less marked relationship, although the data are few. Because the water contents typically are only 2 to 4 per cent apart, they approach the limits of accuracy for shipboard measurement and also reflect the deviations expected in a typical lithologic unit.

\section{Density and Acoustic Velocity}

Wet bulk density, acoustic velocity, and impedance (density times velocity) also are presented graphically in Figure 18. The three physical/lithologic sequences that are defined by the water content and porosity data also are apparent in the wet bulk density data. Wet bulk densities in the upper 408 meters average about $1.60 \mathrm{~g} / \mathrm{cc}$ and exhibit considerable scatter. From about 408 to 724 meters, the densities of the siliceous and calcite-cemented claystones increase somewhat erratically to about $2.05 \mathrm{~g} / \mathrm{cc}$ and remain approximately constant at $2.05 \mathrm{~g} / \mathrm{cc}$ in the black claystones below 724 $\mathrm{m}$. The limestone and sandstone layers that were tested had densities which typically ranged from 2.05 to 2.40 $\mathrm{g} / \mathrm{cc}$; however, a thin dolostone layer at 858 meters and sideritic limestones at 951 meters had densities of 2.91 and $3.57 \mathrm{~g} / \mathrm{cc}$, respectively. For the basalt specimens, measured densities ranged from 2.50 to $2.57 \mathrm{~g} / \mathrm{cc}$.

Measured acoustic velocity increases systematically from $1.50 \mathrm{~km} / \mathrm{sec}$ at 55 meters to about $1.95 \mathrm{~km} / \mathrm{sec}$ at 960 meters. Many claystone layers exhibited velocities up to $2.50 \mathrm{~km} / \mathrm{sec}$, probably because they are cemented by calcite and/or recrystallized silica. Sandstone and limestone beds have velocities ranging from 2.75 to 4.80 $\mathrm{km} / \mathrm{sec}$, and acoustic velocities for the basalt vary from 3.90 to $4.45 \mathrm{~km} / \mathrm{sec}$. Based on contrasts in acoustic impedance, the major acoustic reflectors appear to be (a) sandstone near 170 meters, (b) calcareous turbidites and cemented claystone near 408 meters, and (c) basalt at 
TABLE 9

Physical Properties Data, Site 386

\begin{tabular}{|c|c|c|c|c|c|c|c|c|c|c|c|c|c|c|}
\hline \multirow[b]{3}{*}{$\begin{array}{c}\text { Sample } \\
\text { (Interval in } \mathrm{cm} \text { ) }\end{array}$} & \multirow[b]{3}{*}{$\begin{array}{l}\text { Sub-Bottom } \\
\text { Depth (m) }\end{array}$} & \multirow{2}{*}{\multicolumn{2}{|c|}{$\begin{array}{l}\text { Velocity } \\
(\mathrm{km} / \mathrm{sec})\end{array}$}} & \multirow{2}{*}{\multicolumn{2}{|c|}{$\begin{array}{c}\begin{array}{c}\text { GRAPE } \\
\text { Special } \\
2 \text {-minute } \\
\text { Count }\end{array} \\
\begin{array}{c}\text { W. B. Den. } \\
\left(\mathrm{g} / \mathrm{cm}^{3}\right)\end{array}\end{array}$}} & \multirow{2}{*}{\multicolumn{2}{|c|}{$\begin{array}{l}\text { GRAPE } \\
\text { Routine }^{\mathrm{a}, \mathrm{b}}\end{array}$}} & \multirow{3}{*}{$\begin{array}{l}\text { Thermal } \\
\text { Conduc- } \\
\text { tivity } \mathrm{c}^{-} \\
\text {(mcal/ } \\
\left.\mathrm{cm}-\mathrm{sec}-{ }^{\circ} \mathrm{C}\right)\end{array}$} & \multirow{3}{*}{$\begin{array}{l}\text { Shear } \\
\text { Strength } \\
\text { Undist./ } \\
\text { Rem. } \\
\left(\mathrm{g} / \mathrm{cm}^{2}\right)\end{array}$} & \multirow{2}{*}{\multicolumn{3}{|c|}{ Syringe or Rock Chunk }} & \multirow[b]{3}{*}{$\begin{array}{l}\text { Impedance } \\
\left(\mathrm{g} / \mathrm{cm}^{2}-\right. \\
\mathrm{sec}) \times 10^{5}\end{array}$} & \multirow[b]{3}{*}{ Lithology } \\
\hline & & & & & & & & & & & & & & \\
\hline & & $\begin{array}{l}\quad(\mathrm{km} / \mathrm{s} \\
\text { Para. } \\
\text { Beds }\end{array}$ & $\begin{array}{l}\text { sec) } \\
\text { Perp. } \\
\text { Beds }\end{array}$ & $\begin{array}{l}\quad \mathrm{g} / \mathrm{c} \\
\text { Para. } \\
\text { Beds }\end{array}$ & $\begin{array}{l}\left.\mathrm{m}^{3}\right) \\
\text { Perp. } \\
\text { Beds }\end{array}$ & $\begin{array}{l}\text { W. B. } \\
\text { Den. } \\
\left(\mathrm{g} / \mathrm{cm}^{3}\right)\end{array}$ & $\begin{array}{l}\text { Por. } \\
(\%)\end{array}$ & & & $\begin{array}{l}\text { Water } \\
\text { Cont. } \\
(\%)\end{array}$ & $\begin{array}{l}\text { Wet Bulk } \\
\text { Den. } \\
\left(\mathrm{g} / \mathrm{cm}^{3}\right)\end{array}$ & $\begin{array}{l}\text { Por. } \\
(\%)\end{array}$ & & \\
\hline $\begin{array}{l}1-2,63 \\
1-2,128 \\
1-3,29 \\
1-3,130 \\
1-4,45\end{array}$ & $\begin{array}{l}54.7 \\
55.4 \\
55.9 \\
56.9 \\
57.5\end{array}$ & & & & & $\begin{array}{l}1.47 \\
1.47 \\
1.55 \\
1.55 \\
1.54\end{array}$ & $\begin{array}{l}73 \\
73 \\
68 \\
68 \\
69\end{array}$ & & $\begin{array}{l}19 / \\
30 / \\
17 / \\
41 / \\
33 /\end{array}$ & $\begin{array}{l}45 \\
44 \\
44 \\
44 \\
41\end{array}$ & $\begin{array}{l}1.54 \\
1.55 \\
1.57 \\
1.53 \\
1.59\end{array}$ & $\begin{array}{l}69 \\
68 \\
66 \\
68 \\
66\end{array}$ & & $\begin{array}{l}\text { Nanno ooze } \\
\text { Nanno ooze } \\
\text { Nanno ooze } \\
\text { Nanno ooze } \\
\text { Nanno ooze }\end{array}$ \\
\hline $\begin{array}{l}1-4,120 \\
1-5,22 \\
1-5,95-110 \\
1-6,27 \\
1-6,126-134\end{array}$ & $\begin{array}{l}58.3 \\
58.8 \\
59.6 \\
60.4 \\
61.4\end{array}$ & $\begin{array}{l}1.54 \\
1.60\end{array}$ & 1.50 & & & $\begin{array}{l}1.54 \\
1.59 \\
1.59 \\
1.59 \\
1.59\end{array}$ & $\begin{array}{l}69 \\
65 \\
65 \\
66 \\
66\end{array}$ & & $\begin{array}{r}33 / \\
29 / \\
621 \\
505 / \\
538 /\end{array}$ & $\begin{array}{l}41 \\
41 \\
34 \\
41 \\
40\end{array}$ & $\begin{array}{l}1.59 \\
1.63 \\
1.70 \\
1.64 \\
1.61\end{array}$ & $\begin{array}{l}65 \\
67 \\
57 \\
68 \\
64\end{array}$ & $\begin{array}{l}2.62 \\
2.41\end{array}$ & $\begin{array}{l}\text { Nanno ooze } \\
\text { Nanno ooze } \\
\text { Nanno ooze } \\
\text { Stiff brown clay } \\
\text { Stiff brown clay }\end{array}$ \\
\hline $\begin{array}{l}2-5,136-142 \\
3-1,140-145 \\
4-4,89 \\
4-4,104-112 \\
4-5,20,45 \\
\quad 75,105\end{array}$ & $\begin{array}{l}107.5 \\
139.4 \\
152.6 \\
152.8 \\
153.4- \\
154.2\end{array}$ & $\begin{array}{l}1.50 \\
1.56 \\
\\
1.59\end{array}$ & $\begin{array}{l}1.51 \\
1.58\end{array}$ & & & $\begin{array}{l}1.66 \\
1.66 \\
1.70\end{array}$ & $\begin{array}{l}61 \\
61 \\
58\end{array}$ & $X$ & $\begin{array}{r}371 / \\
710 / \\
1330 /\end{array}$ & $\begin{array}{l}45 \\
40 \\
30\end{array}$ & $\begin{array}{l}1.52 \\
1.65 \\
\\
1.74\end{array}$ & $\begin{array}{l}68 \\
66 \\
53\end{array}$ & $\begin{array}{l}2.30 \\
2.57 \\
\\
2.75\end{array}$ & $\begin{array}{l}\text { Green-blue clay } \\
\text { Gray silty clay } \\
\text { Brown clay } \\
\text { Brown clay } \\
\text { Brown clay }\end{array}$ \\
\hline $\begin{array}{l}4-6,30 \\
4-6,45-50 \\
5-2,25,55 \\
90,120\end{array}$ & $\begin{array}{l}155.0 \\
155.2 \\
158.6- \\
159.5\end{array}$ & 1.58 & 1.58 & & & $\begin{array}{l}1.72 \\
1.72 \\
1.80\end{array}$ & $\begin{array}{l}57 \\
57 \\
52\end{array}$ & $\mathrm{X}$ & $\begin{array}{l}770 / \\
740 /\end{array}$ & 29 & 1.81 & 53 & $2.88^{\mathrm{d}}$ & $\begin{array}{l}\text { Brown clay } \\
\text { Brown clay } \\
\text { Silty clay, calc. clay }\end{array}$ \\
\hline $\begin{array}{l}5-3,26-36 \\
5-3,46\end{array}$ & $\begin{array}{l}160.1 \\
160.3\end{array}$ & 1.57 & 1.56 & & & $\begin{array}{l}1.75 \\
1.75\end{array}$ & $\begin{array}{l}56 \\
56\end{array}$ & & $\begin{array}{r}1204 / \\
994 /\end{array}$ & 32 & 1.73 & 56 & 2.70 & $\begin{array}{l}\text { Brown silty clay } \\
\text { Silty clay }\end{array}$ \\
\hline $\begin{array}{l}5-4,11-19 \\
6-3,5 \\
6-4,42 \\
6-4,80 \\
6-4,110\end{array}$ & $\begin{array}{l}161.5 \\
169.4 \\
171.2 \\
171.6 \\
171.9\end{array}$ & $\begin{array}{l}1.59 \\
1.53 \\
2.72 \\
2.82\end{array}$ & $\begin{array}{l}1.56 \\
\\
1.90 \\
2.72\end{array}$ & & & $\begin{array}{l}1.80 \\
1.58 \\
1.84 \\
1.84 \\
1.84\end{array}$ & $\begin{array}{l}52 \\
66 \\
50 \\
50 \\
50\end{array}$ & $\mathrm{X}$ & $1077 /$ & $\begin{array}{l}32 \\
42 \\
37 \\
21 \\
20\end{array}$ & $\begin{array}{l}1.87 \\
1.59 \\
1.72 \\
2.11 \\
2.12\end{array}$ & $\begin{array}{l}60 \\
67 \\
63 \\
44 \\
43\end{array}$ & $\begin{array}{l}2.92 \\
2.43 \\
3.27 \\
5.74 \\
5.98\end{array}$ & $\begin{array}{l}\text { Brown silty clay } \\
\text { Brown calc. claystone } \\
\text { Gray fine siltstone } \\
\text { Dark gray sandstone } \\
\text { Dark gray sandstone }\end{array}$ \\
\hline $\begin{array}{l}7-2,41 \\
7-3,110 \\
7-3,145 \\
8-1,130 \\
8-2,40,72\end{array}$ & $\begin{array}{l}177.7 \\
179.9 \\
180.2 \\
186.6 \\
187.2 \\
187.5\end{array}$ & 2.06 & $\begin{array}{l}2.02 \\
3.19 \\
1.89 \\
1.61\end{array}$ & & & $\begin{array}{l}1.92 \\
2.06 \\
2.06 \\
1.37\end{array}$ & $\begin{array}{l}45 \\
36 \\
36 \\
79\end{array}$ & $\mathrm{X}$ & & $\begin{array}{l}31 \\
16 \\
44 \\
43\end{array}$ & $\begin{array}{l}1.87 \\
2.34 \\
1.60 \\
1.60\end{array}$ & $\begin{array}{l}57 \\
36 \\
70 \\
69\end{array}$ & $\begin{array}{l}3.78 \\
7.46 \\
3.02 \\
2.58\end{array}$ & $\begin{array}{l}\text { Gray sandstone } \\
\text { Gray sandstone } \\
\text { Gray-brown claystone } \\
\text { Gray-brown claystone } \\
\text { Yellow green clay }\end{array}$ \\
\hline $\begin{array}{l}8-3,115 \\
8-5,145 \\
9-2,50 \\
9-3,108 \\
11-2,45\end{array}$ & $\begin{array}{l}189.4 \\
192.8 \\
206.3 \\
208.4 \\
253.8\end{array}$ & $\begin{array}{l}2.10 \\
2.24 \\
1.75\end{array}$ & $\begin{array}{l}1.85 \\
2.37 \\
1.99 \\
2.28 \\
1.63\end{array}$ & & & $\begin{array}{l}1.66 \\
1.56\end{array}$ & $\begin{array}{l}61 \\
67\end{array}$ & & & $\begin{array}{l}33 \\
26 \\
40 \\
27 \\
41\end{array}$ & $\begin{array}{l}1.81 \\
1.98 \\
1.65 \\
1.94 \\
1.62\end{array}$ & $\begin{array}{l}59 \\
52 \\
66 \\
53 \\
67\end{array}$ & $\begin{array}{l}3.35 \\
4.69 \\
3.28 \\
4.42 \\
2.64\end{array}$ & $\begin{array}{l}\text { Gray sandstone } \\
\text { Gray sandstone } \\
\text { Gray-brown siltstone } \\
\text { Gray sandstone } \\
\text { Gray claystone }\end{array}$ \\
\hline $\begin{array}{l}11-2,128 \\
12-3,50 \\
12-3,96 \\
13-2,36 \\
13-2,120\end{array}$ & $\begin{array}{l}254.7 \\
283.9 \\
284.4 \\
310.9 \\
311.7\end{array}$ & $\begin{array}{l}1.73 \\
1.78 \\
1.67 \\
3.03 \\
1.80\end{array}$ & $\begin{array}{l}1.69 \\
1.89 \\
1.64 \\
2.90 \\
1.71\end{array}$ & & & $\begin{array}{l}1.56 \\
1.56 \\
1.56 \\
1.71 \\
1.71\end{array}$ & $\begin{array}{l}67 \\
67 \\
67 \\
58 \\
58\end{array}$ & & & $\begin{array}{l}40 \\
31 \\
15 \\
30\end{array}$ & $\begin{array}{l}1.62 \\
1.83 \\
2.24 \\
1.81\end{array}$ & $\begin{array}{l}66 \\
57 \\
33 \\
55\end{array}$ & $\begin{array}{l}2.64 \mathrm{~d} \\
3.06 \\
3.00 \\
6.50 \\
3.10\end{array}$ & $\begin{array}{l}\text { Gray-green siltstone } \\
\text { Gray silty claystone } \\
\text { Olive silty claystone } \\
\text { Gray-green sandstone } \\
\text { Gray-green siltstone }\end{array}$ \\
\hline $\begin{array}{l}14-5,98 \\
14-5,134 \\
15-5,44 \\
16-3,32 \\
16-3,107\end{array}$ & $\begin{array}{l}335.4 \\
335.8 \\
353.7 \\
369.3 \\
370.1\end{array}$ & $\begin{array}{l}1.76 \\
1.79 \\
1.77 \\
1.75 \\
1.73\end{array}$ & $\begin{array}{l}1.64 \\
1.65 \\
1.66 \\
1.64 \\
1.65\end{array}$ & & & $\begin{array}{l}1.56 \\
1.56 \\
1.52 \\
1.48 \\
1.48\end{array}$ & $\begin{array}{l}67 \\
67 \\
70 \\
72 \\
72\end{array}$ & & & $\begin{array}{l}38 \\
39 \\
39 \\
42 \\
40\end{array}$ & $\begin{array}{l}1.60 \\
1.67 \\
1.53 \\
1.53 \\
1.54\end{array}$ & $\begin{array}{l}60 \\
66 \\
59 \\
64 \\
61\end{array}$ & $\begin{array}{l}2.62 \\
2.76 \\
2.54 \\
2.51 \\
2.54\end{array}$ & $\begin{array}{l}\text { Siliceous claystone } \\
\text { Olive siliceous claystone } \\
\text { Olive siliceous claystone } \\
\text { Olive siliceous claystone } \\
\text { Olive siliceous claystone }\end{array}$ \\
\hline $\begin{array}{l}17-4,68 \\
17-4,75 \\
18-4,68 \\
18-4,147 \\
18-6,36\end{array}$ & $\begin{array}{l}390.7 \\
390.8 \\
409.3 \\
410.1 \\
412.0\end{array}$ & $\begin{array}{l}1.70 \\
1.80 \\
-3.13 \\
2.06 \\
-4.1\end{array}$ & $\begin{array}{l}1.65 \\
1.66 \\
3- \\
1.90 \\
3-\end{array}$ & & & $\begin{array}{l}1.53 \\
1.53 \\
1.64 \\
1.64 \\
1.72\end{array}$ & $\begin{array}{l}69 \\
69 \\
62 \\
62 \\
57\end{array}$ & & & $\begin{array}{r}36 \\
39 \\
7 \\
25 \\
3\end{array}$ & $\begin{array}{l}1.59 \\
1.58 \\
2.07 \\
1.82 \\
2.24\end{array}$ & $\begin{array}{r}57 \\
62 \\
15 \\
24 \\
6\end{array}$ & $\begin{array}{l}2.62 \\
2.62 \\
6.48 \\
3.46 \\
9.25\end{array}$ & $\begin{array}{l}\text { Green siliceous siltstone } \\
\text { Green siliceous siltstone } \\
\text { Olive clayey limestone } \\
\text { Calcareous silty claystone } \\
\text { Olive limestone }\end{array}$ \\
\hline $\begin{array}{l}18-6,50 \\
19-2,11 \\
19-2,116 \\
20-2,48 \\
21-6,23\end{array}$ & $\begin{array}{l}412.2 \\
415.2 \\
416.3 \\
425.1 \\
440.4\end{array}$ & $\begin{array}{l}2.34 \\
-3.48 \\
3.00 \\
2.23 \\
2.09\end{array}$ & $\begin{array}{l}2.16 \\
8- \\
2.40 \\
2.05 \\
1.93\end{array}$ & & & $\begin{array}{l}1.72 \\
1.55 \\
1.55 \\
1.57 \\
1.60\end{array}$ & $\begin{array}{l}57 \\
68 \\
68 \\
66 \\
65\end{array}$ & & & $\begin{array}{r}22 \\
8 \\
16 \\
13 \\
26\end{array}$ & $\begin{array}{l}1.86 \\
2.14 \\
2.06 \\
1.84 \\
1.79\end{array}$ & $\begin{array}{l}41 \\
17 \\
33 \\
25 \\
46\end{array}$ & $\begin{array}{l}4.02 \\
7.45 \\
4.94 \\
3.77 \\
3.45\end{array}$ & $\begin{array}{l}\text { Silty claystone } \\
\text { Olive marly limestone } \\
\text { Green calcareous claystone } \\
\text { Olive calcareous claystone } \\
\text { Olive calcareous claystone }\end{array}$ \\
\hline $\begin{array}{l}22-1,124 \\
22-1,138 \\
23-6,88 \\
23-6,96 \\
24-4,55\end{array}$ & $\begin{array}{l}443.3 \\
443.5 \\
460.1 \\
460.2 \\
466.2\end{array}$ & $\begin{array}{l}2.65 \\
2.36 \\
2.27 \\
2.26 \\
2.12\end{array}$ & $\begin{array}{l}2.43 \\
1.99 \\
2.08 \\
2.10 \\
1.98\end{array}$ & & & $\begin{array}{l}1.64 \\
1.64 \\
1.66\end{array}$ & $\begin{array}{l}62 \\
62 \\
61\end{array}$ & & & $\begin{array}{l}23 \\
24 \\
28 \\
17 \\
26\end{array}$ & $\begin{array}{l}1.85 \\
1.82 \\
1.74 \\
2.05 \\
1.78\end{array}$ & $\begin{array}{l}42 \\
44 \\
49 \\
36 \\
47\end{array}$ & $\begin{array}{l}4.50 \\
3.62 \\
3.62 \\
4.31 \\
3.52\end{array}$ & $\begin{array}{l}\text { Green calcareous claystone } \\
\text { Olive calcareous claystone } \\
\text { Olive calcareous claystone } \\
\text { Green calcareous claystone } \\
\text { Olive calcareous claystone }\end{array}$ \\
\hline $\begin{array}{l}24-4,102 \\
26-2,40 \\
26-2,53 \\
27-1,64 \\
27-2,37\end{array}$ & $\begin{array}{l}466.7 \\
482.2 \\
482.3 \\
490.4 \\
491.7\end{array}$ & $\begin{array}{l}2.36 \\
2.14 \\
1.94 \\
2.45 \\
1.90\end{array}$ & $\begin{array}{l}2.24 \\
1.96 \\
1.80 \\
2.19 \\
1.73\end{array}$ & & & $\begin{array}{l}1.66 \\
1.54 \\
1.54 \\
1.57\end{array}$ & $\begin{array}{l}61 \\
68 \\
68 \\
67\end{array}$ & & & $\begin{array}{r}18 \\
27 \\
7 \\
23 \\
32\end{array}$ & $\begin{array}{l}2.03 \\
1.76 \\
2.39 \\
1.83 \\
1.71\end{array}$ & $\begin{array}{l}35 \\
48 \\
17 \\
41 \\
56\end{array}$ & $\begin{array}{l}4.55 \\
3.45 \\
4.30 \\
4.01 \\
2.96\end{array}$ & $\begin{array}{l}\text { Green calcareous claystone } \\
\text { Olive claystone } \\
\text { Pale green claystone } \\
\text { Cherty claystone } \\
\text { Gray-green claystone }\end{array}$ \\
\hline $\begin{array}{l}27-2,44 \\
28-4,105 \\
28-4,138 \\
29-2,74 \\
29-2,94\end{array}$ & $\begin{array}{l}491.7 \\
505.0 \\
505.3 \\
511.1 \\
511.3\end{array}$ & $\begin{array}{l}1.90 \\
2.40 \\
1.97 \\
2.12 \\
-2.58\end{array}$ & $\begin{array}{l}1.72 \\
2.39 \\
1.79 \\
2.04 \\
8-\end{array}$ & & & $\begin{array}{l}1.57 \\
1.59 \\
1.59 \\
1.61 \\
1.61\end{array}$ & $\begin{array}{l}67 \\
65 \\
65 \\
64 \\
64\end{array}$ & & & $\begin{array}{l}31 \\
28 \\
25 \\
27 \\
24\end{array}$ & $\begin{array}{l}1.73 \\
1.83 \\
1.68 \\
1.70 \\
1.78\end{array}$ & $\begin{array}{l}53 \\
51 \\
42 \\
45 \\
42\end{array}$ & $\begin{array}{l}2.98 \\
4.39 \\
3.01 \\
3.47 \\
4.59\end{array}$ & $\begin{array}{l}\text { Gray-green claystone } \\
\text { Gray-green chert } \\
\text { Pale green claystone } \\
\text { Gray-green chert } \\
\text { Pale green chert }\end{array}$ \\
\hline
\end{tabular}


TABLE 9 - Continued

\begin{tabular}{|c|c|c|c|c|c|c|c|c|c|c|c|c|c|}
\hline \multirow[b]{3}{*}{$\begin{array}{c}\text { Sample } \\
\text { (Interval in } \mathrm{cm} \text { ) }\end{array}$} & \multirow[b]{3}{*}{$\begin{array}{l}\text { Sub-Bottom } \\
\text { Depth }(\mathrm{m})\end{array}$} & \multirow{2}{*}{\multicolumn{2}{|c|}{$\begin{array}{l}\text { Velocity } \\
(\mathrm{km} / \mathrm{sec})\end{array}$}} & \multirow{2}{*}{$\begin{array}{c}\begin{array}{c}\text { GRAPE } \\
\text { Special } \\
2 \text {-minute } \\
\text { Count } b\end{array} \\
\begin{array}{c}\text { W. B. Den. } \\
\left(\mathrm{g} / \mathrm{cm}^{3}\right)\end{array}\end{array}$} & \multirow{2}{*}{\multicolumn{2}{|c|}{$\begin{array}{l}\text { GRAPE } \\
\text { Routine }^{a, b}\end{array}$}} & \multirow{3}{*}{$\begin{array}{l}\text { Thermal } \\
\text { Conduc- } \\
\text { tivityc } \\
\text { (mcal/ } \\
\left.\text { cm-sec- }{ }^{\circ} \mathrm{C}\right)\end{array}$} & \multirow{3}{*}{$\begin{array}{l}\text { Shear } \\
\text { Strength } \\
\text { Undist./ } \\
\text { Rem. } \\
\left(\mathrm{g} / \mathrm{cm}^{2}\right)\end{array}$} & \multirow{2}{*}{\multicolumn{3}{|c|}{ Syringe or Rock Chunk }} & \multirow[b]{3}{*}{$\begin{array}{l}\text { Impedance } \\
\left(\mathrm{g} / \mathrm{cm}^{2}-\right. \\
\mathrm{sec}) \times 10^{5}\end{array}$} & \multirow[b]{3}{*}{ Lithology } \\
\hline & & & & & & & & & & & & & \\
\hline & & $\begin{array}{l}\quad \mathrm{km} / \mathrm{s} \\
\text { Para. } \\
\text { Beds }\end{array}$ & $\begin{array}{l}\text { sec) } \\
\text { Perp. } \\
\text { Beds }\end{array}$ & \begin{tabular}{ll}
\multicolumn{2}{c|}{$\left(\mathrm{g} / \mathrm{cm}^{3}\right)$} \\
Para. & Perp. \\
Beds & Beds
\end{tabular} & $\begin{array}{c}\text { W. B. } \\
\text { Den. } \\
\left(\mathrm{g} / \mathrm{cm}^{3}\right)\end{array}$ & $\begin{array}{l}\text { Por. } \\
(\%)\end{array}$ & & & $\begin{array}{l}\text { Water } \\
\text { Cont. } \\
(\%)\end{array}$ & $\begin{array}{l}\text { Wet Bulk } \\
\text { Den. } \\
\left(\mathrm{g} / \mathrm{cm}^{3}\right)\end{array}$ & $\begin{array}{l}\text { Por. } \\
(\%)\end{array}$ & & \\
\hline $\begin{array}{l}30-4,122 \\
31-6,47 \\
31-6,140 \\
32-5,39 \\
32-5,64\end{array}$ & $\begin{array}{l}524.1 \\
545.8 \\
546.7 \\
563.0 \\
563.2\end{array}$ & $\begin{array}{l}2.20 \\
1.94 \\
2.05 \\
1.99 \\
2.14\end{array}$ & $\begin{array}{l}1.99 \\
1.80 \\
2.02 \\
1.79 \\
1.90\end{array}$ & & $\begin{array}{l}1.68 \\
1.73 \\
1.73 \\
1.76 \\
1.76\end{array}$ & $\begin{array}{l}60 \\
57 \\
57 \\
55 \\
55\end{array}$ & & & $\begin{array}{l}23 \\
29 \\
23 \\
26 \\
21\end{array}$ & $\begin{array}{l}1.87 \\
1.89 \\
1.86 \\
1.84 \\
1.93\end{array}$ & $\begin{array}{l}43 \\
54 \\
43 \\
48 \\
41\end{array}$ & $\begin{array}{l}3.72 \\
3.40 \\
3.76 \\
3.29 \\
3.67\end{array}$ & $\begin{array}{l}\text { Green cherty claystone } \\
\text { Olive radiolarian mudstone } \\
\text { Gray-green silty claystone } \\
\text { Gray-green claystone } \\
\text { Gray-green claystone }\end{array}$ \\
\hline $\begin{array}{l}33-2,8 \\
33-2,80 \\
34-2,63 \\
35-5,92 \\
35-5,124\end{array}$ & $\begin{array}{l}576.8 \\
577.5 \\
606.3 \\
638.9 \\
639.2\end{array}$ & $\begin{array}{l}2.58 \\
2.10 \\
1.91 \\
3.13 \\
1.84\end{array}$ & $\begin{array}{l}2.53 \\
1.97 \\
1.77 \\
3.22 \\
1.69\end{array}$ & & $\begin{array}{l}1.73 \\
1.73 \\
1.78 \\
1.93 \\
1.93\end{array}$ & $\begin{array}{l}57 \\
57 \\
54 \\
44 \\
44\end{array}$ & & & $\begin{array}{l}22 \\
23 \\
26 \\
10 \\
22\end{array}$ & $\begin{array}{l}1.89 \\
1.92 \\
1.92 \\
2.36 \\
2.01\end{array}$ & $\begin{array}{l}41 \\
44 \\
49 \\
23 \\
43\end{array}$ & $\begin{array}{l}4.78 \\
3.78 \\
3.40 \\
7.60 \\
3.40\end{array}$ & $\begin{array}{l}\text { Gray-green siliceous claystone } \\
\text { Pale green claystone } \\
\text { Gray-green silty claystone } \\
\text { Pale green limestone } \\
\text { Red claystone }\end{array}$ \\
\hline $\begin{array}{l}36-4,135 \\
38-2,22 \\
38-2,29 \\
39-4,58 \\
39-4,64\end{array}$ & $\begin{array}{l}647.4 \\
691.1 \\
691.2 \\
704.0 \\
704.1\end{array}$ & $\begin{array}{l}2.05 \\
2.04 \\
1.95 \\
2.07 \\
1.87\end{array}$ & $\begin{array}{l}1.80 \\
1.85 \\
1.84 \\
1.90 \\
1.83\end{array}$ & & $\begin{array}{l}2.00 \\
1.62 \\
1.62 \\
1.70 \\
1.70\end{array}$ & $\begin{array}{l}40 \\
64 \\
64 \\
58 \\
58\end{array}$ & & & $\begin{array}{l}21 \\
27 \\
28 \\
23 \\
27\end{array}$ & $\begin{array}{l}2.04 \\
1.97 \\
1.88 \\
1.92 \\
1.78\end{array}$ & $\begin{array}{l}43 \\
53 \\
54 \\
45 \\
47\end{array}$ & $\begin{array}{l}3.67 \\
3.64 \\
3.46 \\
3.65 \\
3.26\end{array}$ & $\begin{array}{l}\text { Red claystone } \\
\text { Dark brown zeolitic claystone } \\
\text { Brown zeolitic claystone } \\
\text { Red-brown zeolitic claystone } \\
\text { Pale green zeolitic claystone }\end{array}$ \\
\hline $\begin{array}{l}41-5,34 \\
41-5,97 \\
42-5,95 \\
42-5,144 \\
43-3,88\end{array}$ & $\begin{array}{l}723.8 \\
724.5 \\
734.0 \\
734.4 \\
740.2\end{array}$ & $\begin{array}{l}2.24 \\
2.37 \\
1.85 \\
2.36 \\
1.98\end{array}$ & $\begin{array}{l}1.94 \\
2.07 \\
1.81 \\
2.11 \\
1.99\end{array}$ & & $\begin{array}{l}1.81 \\
1.81 \\
1.84 \\
1.84 \\
1.54\end{array}$ & $\begin{array}{l}52 \\
52 \\
50 \\
50 \\
68\end{array}$ & & & $\begin{array}{l}20 \\
17 \\
24 \\
19 \\
18\end{array}$ & $\begin{array}{l}2.06 \\
2.17 \\
1.81 \\
2.06 \\
1.89\end{array}$ & $\begin{array}{l}41 \\
37 \\
43 \\
40 \\
34\end{array}$ & $\begin{array}{l}4.00 \\
4.49 \\
3.28 \\
4.35 \\
3.76\end{array}$ & $\begin{array}{l}\text { Red-brown claystone } \\
\text { Gray-green claystone } \\
\text { Black claystone } \\
\text { Gray-green silty claystone } \\
\text { Black claystone }\end{array}$ \\
\hline $\begin{array}{l}44-3,60 \\
44-3,87 \\
45-5,120 \\
46-5,128 \\
46-5,147\end{array}$ & $\begin{array}{l}749.4 \\
749.7 \\
772.4 \\
781.7 \\
781.9\end{array}$ & $\begin{array}{l}2.14 \\
2.58 \\
2.10 \\
2.04 \\
2.02\end{array}$ & $\begin{array}{l}1.97 \\
2.24 \\
1.92 \\
1.88 \\
1.85\end{array}$ & & $\begin{array}{l}1.79 \\
1.79 \\
1.91 \\
1.87 \\
1.87\end{array}$ & $\begin{array}{l}53 \\
53 \\
46 \\
48 \\
48\end{array}$ & & & $\begin{array}{l}20 \\
18 \\
19 \\
20 \\
21\end{array}$ & $\begin{array}{l}2.02 \\
2.07 \\
2.05 \\
2.03 \\
2.04\end{array}$ & $\begin{array}{l}39 \\
36 \\
39 \\
40 \\
43\end{array}$ & $\begin{array}{l}3.98 \\
4.64 \\
3.94 \\
3.82 \\
3.77\end{array}$ & $\begin{array}{l}\text { Pale green claystone } \\
\text { Black radiolarian mudstone } \\
\text { Pale green claystone } \\
\text { Red-brown claystone } \\
\text { Gray-green claystone }\end{array}$ \\
\hline $\begin{array}{l}47-5,39 \\
47-5,148 \\
49-4,86 \\
50-5,102 \\
50-5,138\end{array}$ & $\begin{array}{l}790.2 \\
791.3 \\
808.2 \\
819.3 \\
819.7\end{array}$ & $\begin{array}{l}1.99 \\
1.98 \\
2.04 \\
1.99 \\
2.00\end{array}$ & $\begin{array}{l}1.79 \\
1.83 \\
1.87 \\
1.84 \\
1.82\end{array}$ & & $\begin{array}{l}1.86 \\
1.86 \\
1.87 \\
1.84\end{array}$ & $\begin{array}{l}48 \\
48 \\
48 \\
50\end{array}$ & & & $\begin{array}{l}28 \\
19 \\
19 \\
19 \\
20\end{array}$ & $\begin{array}{l}1.95 \\
2.03 \\
2.06 \\
2.06 \\
2.01\end{array}$ & $\begin{array}{l}57 \\
39 \\
39 \\
39 \\
40\end{array}$ & $\begin{array}{l}3.49 \\
3.72 \\
3.85 \\
3.79 \\
3.66\end{array}$ & $\begin{array}{l}\text { Light gray claystone } \\
\text { Dark gray claystone } \\
\text { Gray-green claystone } \\
\text { Gray-green calcareous claystone } \\
\text { Olive claystone }\end{array}$ \\
\hline $\begin{array}{l}51-5,31 \\
52-6,30 \\
53-4,104 \\
54-6,42 \\
54-6,83\end{array}$ & $\begin{array}{l}828.6 \\
839.2 \\
846.4 \\
858.6 \\
859.0\end{array}$ & $\begin{array}{l}2.10 \\
2.30 \\
2.02 \\
-4.78 \\
2.08\end{array}$ & $\begin{array}{l}1.93 \\
2.08 \\
1.85 \\
8- \\
1.85\end{array}$ & & $\begin{array}{l}1.81 \\
1.69 \\
1.77 \\
1.94 \\
1.94\end{array}$ & $\begin{array}{l}52 \\
59 \\
54 \\
43 \\
43\end{array}$ & & & $\begin{array}{r}20 \\
19 \\
20 \\
6 \\
12\end{array}$ & $\begin{array}{l}2.03 \\
2.05 \\
2.02 \\
2.91 \\
2.07\end{array}$ & $\begin{array}{l}41 \\
40 \\
40 \\
18 \\
40\end{array}$ & $\begin{array}{r}3.92 \\
4.26 \\
3.74 \\
13.91 \\
3.83\end{array}$ & $\begin{array}{l}\text { Crystallized marly chalk } \\
\text { Gray claystone } \\
\text { Gray-blue claystone } \\
\text { Olive-gray limestone } \\
\text { Black claystone }\end{array}$ \\
\hline $\begin{array}{l}55-5,68 \\
55-5,82 \\
56-4,10 \\
58-4,52 \\
59-5,34\end{array}$ & $\begin{array}{l}866.6 \\
866.7 \\
873.9 \\
893.5 \\
904.0\end{array}$ & $\begin{array}{l}2.08 \\
1.95 \\
1.98 \\
2.00 \\
1.97\end{array}$ & $\begin{array}{l}1.81 \\
1.82 \\
1.86 \\
1.84 \\
1.83\end{array}$ & & $\begin{array}{l}1.74 \\
1.74 \\
1.77 \\
1.84 \\
1.81\end{array}$ & $\begin{array}{l}56 \\
56 \\
54 \\
50 \\
52\end{array}$ & & & $\begin{array}{l}20 \\
22 \\
11 \\
20 \\
19\end{array}$ & $\begin{array}{l}2.04 \\
1.96 \\
1.80 \\
2.03 \\
2.08\end{array}$ & $\begin{array}{l}41 \\
44 \\
19 \\
41 \\
39\end{array}$ & $\begin{array}{l}3.69 \\
3.57 \\
3.35 \\
3.74 \\
3.81\end{array}$ & $\begin{array}{l}\text { Black claystone } \\
\text { Olive claystone } \\
\text { Gray calcareous claystone } \\
\text { Black calcareous claystone } \\
\text { Gray-black claystone }\end{array}$ \\
\hline $\begin{array}{l}61-4,80 \\
62-4,114 \\
63-4,74 \\
64-4,79 \\
64-4,85\end{array}$ & $\begin{array}{l}922.1 \\
931.9 \\
941.0 \\
950.6 \\
950.7\end{array}$ & $\begin{array}{l}2.33 \\
2.01 \\
1.90 \\
3.92 \\
2.16\end{array}$ & $\begin{array}{l}2.22 \\
1.86 \\
1.77 \\
3.53 \\
1.93\end{array}$ & & $\begin{array}{l}1.85 \\
1.81 \\
1.73 \\
1.78 \\
1.78\end{array}$ & $\begin{array}{l}49 \\
52 \\
58 \\
56 \\
56\end{array}$ & & & $\begin{array}{r}17 \\
20 \\
19 \\
1 \\
19\end{array}$ & $\begin{array}{l}2.12 \\
2.02 \\
2.09 \\
3.57 \\
2.06\end{array}$ & $\begin{array}{r}36 \\
40 \\
39 \\
5 \\
40\end{array}$ & $\begin{array}{r}4.71 \\
3.76 \\
3.70 \\
12.60 \\
3.98\end{array}$ & $\begin{array}{l}\text { Black-green claystone } \\
\text { Black claystone } \\
\text { Black-green claystone } \\
\text { Olive-gray sandstone } \\
\text { Black radiolarian mudstone }\end{array}$ \\
\hline $\begin{array}{l}65-3,103 \\
66-1,110 \\
66-2,12 \\
66-2,62 \\
66-2,90\end{array}$ & $\begin{array}{l}958.8 \\
965.3 \\
965.8 \\
966.3 \\
966.6\end{array}$ & $\begin{array}{l}2.35 \\
4.17 \\
4.29 \\
-2.45 \\
-3.92\end{array}$ & $\begin{array}{l}1.94 \\
4.03 \\
5- \\
2-\end{array}$ & $\begin{array}{l}-2.57- \\
-2.51- \\
-2.18- \\
-2.50-\end{array}$ & $\begin{array}{l}1.77 \\
2.00 \\
1.89 \\
1.89 \\
1.89\end{array}$ & $\begin{array}{l}54 \\
40 \\
47 \\
47 \\
47\end{array}$ & & & 19 & 2.12 & 40 & $\begin{array}{r}4.11 \\
10.36 \\
10.77 \\
5.36 \\
9.80\end{array}$ & $\begin{array}{l}\text { Black claystone } \\
\text { Dark gray basalt } \\
\text { Dark gray basalt } \\
\text { Chlorite vein } \\
\text { Dark gray basalt }\end{array}$ \\
\hline $66-2,106$ & 966.8 & -4.45 & & $-2.53-$ & 1.89 & 47 & & & & & & 11.26 & Chlorite vein \\
\hline
\end{tabular}

${ }^{a}$ Routine GRAPE values are averages for entire core section, normally based on eight measurements between 10 and $140 \mathrm{~cm}$ in section. A complete listing of routine GRAPE data is given in the Appendix.

${ }^{\mathrm{b}}$ Assumed grain density $=2.65 \mathrm{~g} / \mathrm{cm}^{3}$.

${ }^{c}$ Conductivity data not processed. Location of measurement indicated by $\mathrm{X}$.

${ }^{\mathrm{d}}$ Determined using GRAPE wet-bulk density.

964 meters. Correlation with the seismic profiler record is discussed later in this chapter.

\section{BIOSTRATIGRAPHY}

Sediments cored at Site 386 encompass the stratigraphic interval from Albian to Pleistocene. As is usually the case, calcareous nannofossils constitute the bestrepresented fossil group, occurring in 53 of the 66 cores taken at this site; foraminifers and radiolarians are of much spottier occurrence, especially in the Cenozoic. In the case of the foraminifers, this is probably related to the depth of the site and possibly to a low $p \mathrm{H}$ environment within the predominantly greenish and grayish sediments. For the radiolarians, changes in the level of productivity as well as presently little known factors of the sedimentary and diagenetic environments contribute to their poor representation in the stratigraphic record.

In the Cenozoic part of the sequence, foraminifers are essentially restricted to redeposited sediments whose sources were above the lysocline. Exceptions may be the upper Miocene and Pleistocene occurrences which are not clearly within turbidite sands, and occasional sparse 


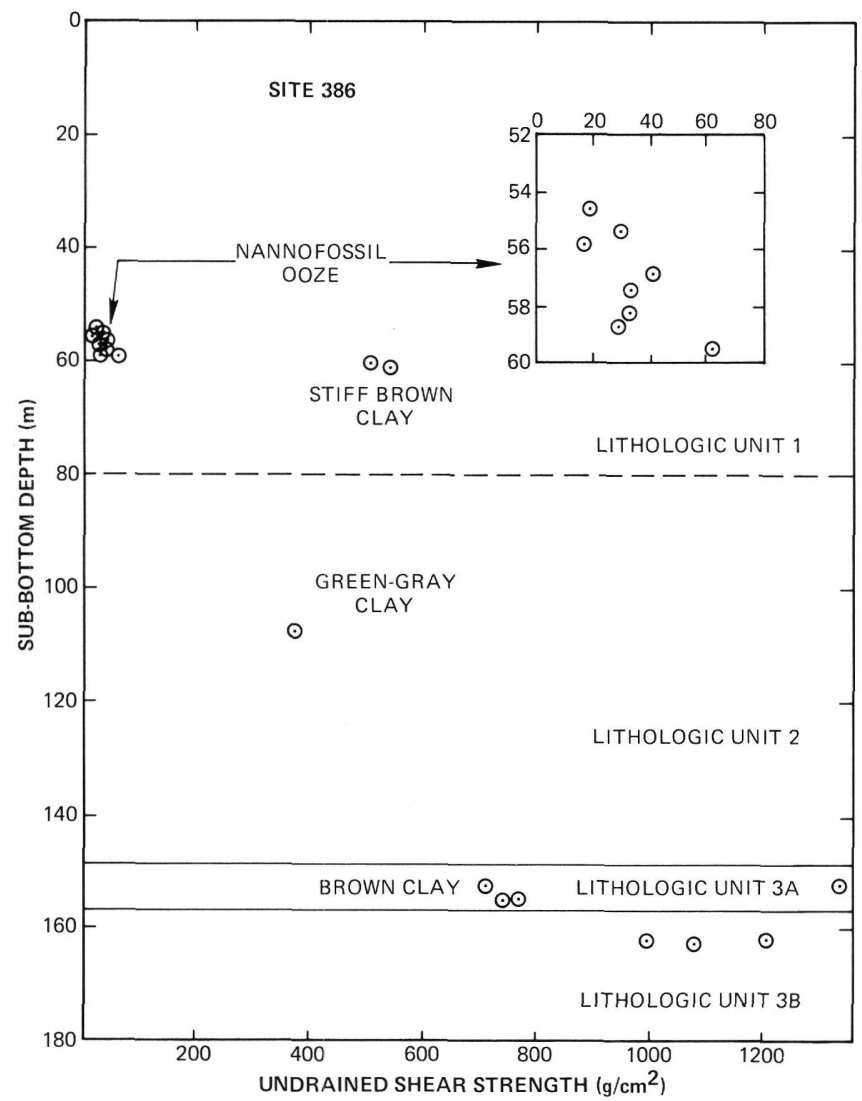

Figure 17. Shear strength, Site 386.

"dwarfed" faunas of small globigerinids. The latter may represent selective dissolution or some unusual environmental conditions in the surface waters.

Well-preserved radiolarians occur only in a short sequence in the middle Eocene; they disappear downward as chert is approached. Poorly preserved (corroded) radiolarians were again encountered in the lower Eocene, below the chert. Cretaceous radiolarians are also poorly preserved as a result of replacement and overgrowth, but proved to be useful in dating the lower part of the otherwise unfossiliferous, varicolored (dominantly red) clay unit. Recrystallized as well as pyritized radiolarians are a sporadic but consistent component of the Cretaceous black shales, but their degree of preservation markedly decreases downhole.

One of the outstanding paleontological results at this site was the recovery of a well-preserved record of $\mathrm{Al}$ bian and Cenomanian planktonic foraminifers from an open-ocean (pelagic) rather than a shelf (neritic) sequence. They are generally sparse and show no consistent relationship to lithological type within the black shales, but are well preserved and diverse.

\section{Cenozoic Foraminifers}

Foraminifers are of very limited occurrence in the Cenozoic sediments cored at Site 386. They are limited to the upper 12 cores (?upper Eocene to lower Quaternary). Except for the pelagic sediment of Cores 1 and 2, substantial numbers of foraminifers were found only in the sands of thin turbidites whose source apparently was above the local CCD. Bathymetric peaks up to 1800 meters high are found $10 \mathrm{~km}$ south and $30 \mathrm{~km}$ north of Site 386, and these are likely sources for the turbidites. The remainder of the sediment (Sample 4, CC and Cores 9 to 12) contains unusual, dwarfed assemblages that could not be specifically determined.

A lower Pleistocene fauna was recovered in Sections 5 and 6 and the core-catcher sample of Core 1. Present are such typical Pleistocene markers as Globorotalia menardii, Pulleniatina obliquiloculata, and Globorotalia truncatulinoides. The lower Pleistocene date for these assemblages is based on the presence of Globorotalia sp. 1 of Phleger et al. (1953), a form whose upper limit in Atlantic sediments occurs just above the Olduvai normal paleomagnetic event (Ericson and Wollin, 1968 ) and has an interpolated age of about 1.55 m.y.

Core 2, Section 1, 137-139 cm, contains solution impoverished fauna of upper Miocene aspect (probably equivalent to Zone N.17 of Blow, 1969). Included are solution-resistant forms such as Globoquadrina dehiscens, Globogerina nepenthes, and Sphaeroidinella subdehiscens.

Core 3 is barren of foraminifers.

Section 1 of Core 4 contains a dwarfed, apparently lower Miocene assemblage that includes Globigerinita juvenilis and Cassigerinella chipolensis, while a turbidite sand in Section $6(87-88 \mathrm{~cm})$ contains a normal uppermost Oligocene or lowermost Miocene assemblage with Globigerina ciperoensis, G. praebulloides, G. angulisuturalis, Globigerinoides primordius, and Globoquadrina sellii. The core-catcher sample of this core contains an assemblage of tiny, indeterminate globigerinids.

A turbidite sand in Core 5 (core catcher) has a midOligocene fauna with Catapsydrax unicavus, Globoquadrina sellii, G. venezuelana, and Globorotalia $\mathrm{cf}$. G. opima.

The presence in Core 6 (core catcher) of Globigerina prasaepis probably indicates Oligocene, as this species also occurs in a lower Oligocene fauna in Core 8 (core catcher) together with Globoquadrina tapurierisis, Catapsydrax dissimilis, C. unicavus, and Globigerina pseudoampliapertura.

Cores 9 through 12 all contain dwarfed assemblages of small globigerinids. The only date that can be assigned with confidence is Paleogene on the basis of the occurrence in these assemblages of Chiloguembelina spp. A single specimen of Subbotina yeguaensis (?Eocene) was found in Core 12.

\section{Mesozoic Foraminifers}

Cores 35 through 46 are composed of reddish, redgray, and dark gray pelagic clays. The red-gray clays yield primitive agglutinated forms and the dark gray clays are barren. This is essentially the same situation as at Site 385.

Many samples from Cores 47 through 57 contain common to abundant foraminifers. They occur in light gray laminae and thin dark interbeds of the green-gray 


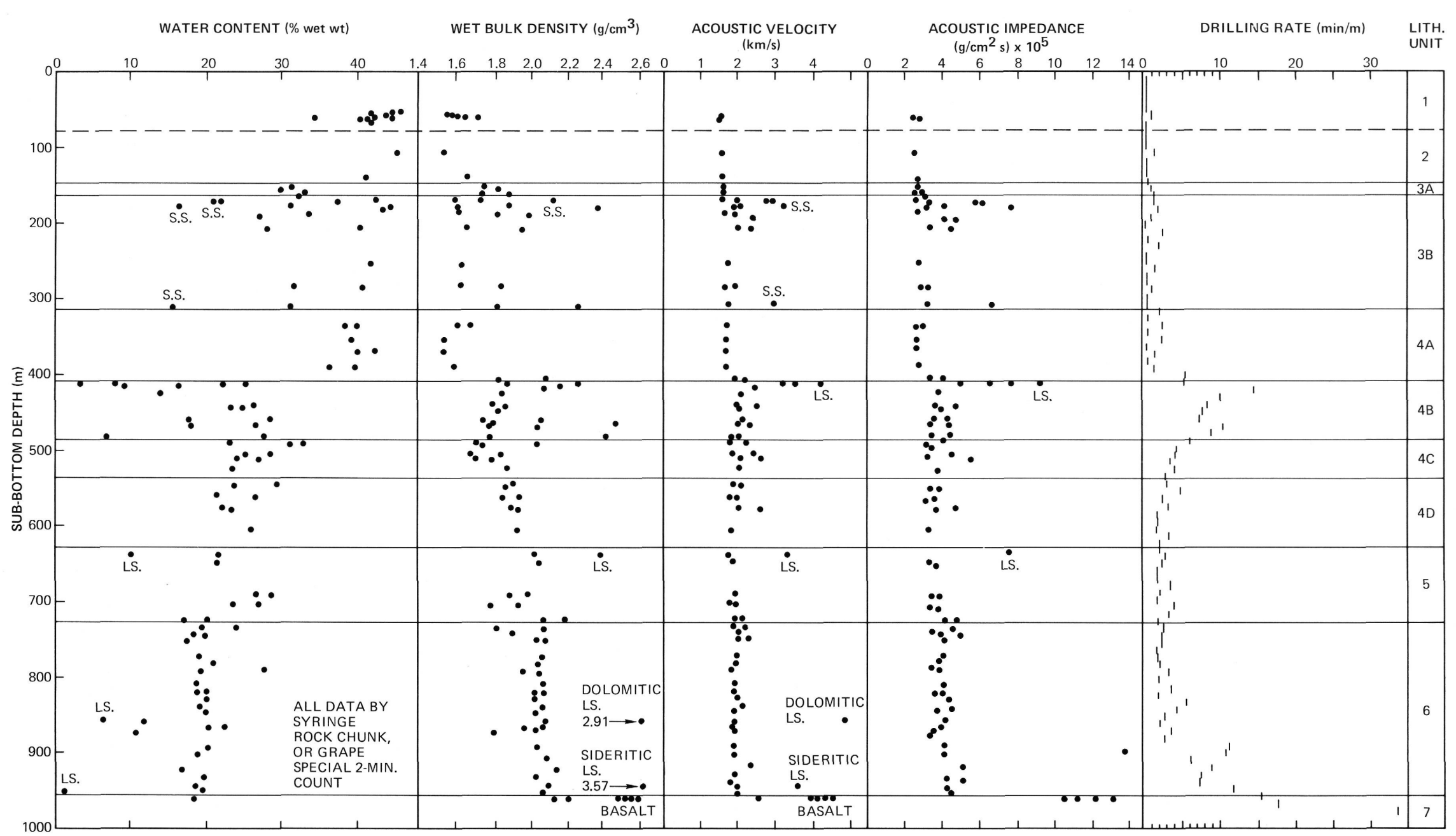

Figure 18. Physical properties data, Site 386. 
and black claystone sequence. Their abundance fluctuates without apparent reason from one such layer to another, as illustrated by the fact that only 42 of 62 samples collected from these layers provided foraminifers (see distribution chart, McNulty, this volume). The specimens are calcite filled and, typically, somewhat overgrown, but many are moderately well preserved and some very well preserved. The diversity appears rather low, and the dominant forms are Hedbergella trochoides (Gandolfi), Praeglobotruncana stephani (Gandolfi), Planomalina buxtorfi (Gandolfi), Rotalipora apenninica (Gandolfi), R. evoluta Sigal?, Thalmanninella subticinensis (Gandolfi), T. ticinensis (Gandolfi), Ticinella breggiensis (Gandolfi), and T. roberti (Gandolfi). This is a well-known assemblage of the Albian-Cenomanian, but its pattern of first appearances does not agree well with those most recently reported (van Hinte, 1976). Perhaps this is due to gaps in the record that result from samples that yielded few or no specimens. Perhaps the pattern remains to be accurately established (Hermes, 1969, p. 37, table 2). In any event, it appears that the basal part of Core 57 may be middle Albian; Sections 57-2 to 54-3 are upper Albian; Section 54-3 (appearance of $P$. buxtorfi and $P$. apenninica) to Section 51-4 Vraconian; and Sections 51-4 to 47-1 are lower Cenomanian.

Below Core 57 foraminifers decrease drastically in numbers. Occasional, unidentifiable hedbergellids occur in samples from Cores 57 through 60 but they were not found below Core 60 .

The occurrence of species above their apparent extinction horizon (see distribution chart, McNulty, this volume) suggests some reworking, which in turn provides some support for explaining the fossiliferous and calcareous bands of the black claystones as turbiditic concentrations rather than interruptions of reducing conditions (see Summary and Conclusions, this chapter).

\section{Nannofossils}

Most cores (53 out of 66) at this site contain generally abundant nannofossils. Species assemblages of Quaternary to Albian age are observed. Well-preserved nannofossils of the Pleistocene and Holocene epochs occur abundantly in Core 1 . Reworked Cretaceous forms are common in some of these samples. Little sediment was recovered in Cores 2 and 3, and no diagnostic nannoliths were observed. Sample 2-1, $135 \mathrm{~cm}$ contains a poor late Miocene assemblage (Discoaster quinqueramus Zone). The upper half of Core 4 is barren of nannofossils except for one thin layer (in Section 1, at $100 \mathrm{~cm}$ ) where abundant, moderately well preserved nannofossils of early Miocene age occur (Sphenolithus heteromorphus Zone).

A presumably continuous sequence of earliest Miocene to latest Paleocene is represented in Cores 4, Section 4 through Core 34. Preservation of nannofossils and recovery were so poor in the younger part of this sequence that age assignments by means of nannofossils remain tentative for the upper Eocene and Oligocene epochs. The lower portion of Core 4 yields assemblages of the Triquetrorhabdulus carinatus Zone at the Oligocene/Miocene boundary. The late Oligocene Sphenolithus ciperoensis Zone is recognized in Core 5. Middle Oligocene assemblages (Sphenolithus predistentus and Sphenolithus distentus zones) occur in Cores 6 through 10. Core 11 and the upper three sections of Core 12 yield assemblages of early Oligocene (Helicosphaera reticulata Zone) age. Severely overgrown Isthmolithus recurvus occur in the lower three sections of Core 12 establishing a latest Eocene age for these sediments. Core 13 contains very poorly preserved nannofossils suggesting an age close to the middle late Eocene boundary (Discoaster saipanensis or Chiasmolithus oamaruensis sub-zones).

The lithologic change from volcaniclastic turbidites (Core 13) to siliceous turbidites (Core 14) is clearly reflected in the preservation of the nannofossils; the severe overgrowth observed in Cores 6 to 13 becomes moderate below. Assemblages of middle Eocene (Nannotetrina fulgens Zone and Discoaster bifax Subzone) are recognized in Cores 14 through 25. All six zones or sub-zones of the early Eocene are recognizable within Cores 26 through 34. The effects of overgrowth decrease steadily downward within these sediments, and disappear in Core 34.

Moderately etched assemblages of the latest Paleocene (Campylosphaera eodela Sub-zone) occur in the lower half of Core 34. The very top of Core 35 yields assemblages of late middle Paleocene age (Discoaster mohleri Zone), but the rest of Section 1 as well as Sections 2 and 3 are barren.

Micula mura characterizing the latest Maestrichtian occur in Section 4 of Core 35. Section 35-5 is of middle Maestrichtian age. Preservation of these assemblages is poor. Cores 36 through 44 are barren except for a moderately etched pre-Turonian assemblage in Section 4 of Core 44. Well preserved Cenomanian nannoliths (including Lithraphidites alatus) alternate with moderately preserved assemblages in Cores 45 through 49.

Late Albian nannofossils of varying preservation are present in Cores 50 through 57. Cores 58 through 60 are of middle Albian age (Prediscosphaera cretacea Zone), Cores 61 through 64 are barren, but one sample (65-1, $130 \mathrm{~cm}$, contains a moderately well-preserved nannofossil assemblage of the Prediscosphaera cretacea Zone. This assemblage dates the sediments only 3 meters above the underlying basalts as early Albian.

\section{Palynomorphs}

Forty-five samples from Cores 44 to 65 in the greengray and black clays were processed and examined for palynomorphs. Surprisingly, and in dramatic contrast to the black clays at Site $\mathbf{3 8 7}$ on the western Bermuda Rise, these samples failed to yield dinoflagellates or sporomorphs (D. Habib, personal communication, 1976).

\section{Radiolarians}

Radiolarians are consistently abundant and well preserved in the middle Eocene siliceous turbidites of Cores 14 through the upper part of Core 17. In the interval from Section 3 of Core 17 through Section 5 of Core 
18 their occurrence becomes sporadic and the interval of Core 19 through Core 30 is generally barren of siliceous microfossils. Where present, the radiolarians are accompanied by diatoms and siliceous sponge spicules. In the lower Eocene radiolarian mudstones of Cores 31 through 34 , radiolarians are again present, but their preservation is poor owing to recrystallization, making zonal assignments very tentative.

Radiolarians are also present in the Cretaceous red claystones and continue into the underlying green and black claystones of the Cenomanian and Albian; they are, however, replaced by and overgrown with chalcedony and cristobalite and fine morphological features are obliterated. The presence of a sufficient number of forms with unique test morphology nonetheless allows recognition of the characteristic radiolarian associations described by Moore (1973) from DSDP Leg 17 materials.

\section{Cenozoic}

The radiolarian assemblages of the middle Eocene siliceous turbidites (Cores 14 through 18) are all assigned to the Thyrsocyrtis triacantha Zone (determinations by R. Goll). On the basis of shipboard determinations, the poorly preserved assemblage of Core 31 was assigned to the lower middle Eocene Theocampe mongolfieri Zone. This was primarily based on the occurrence of Thyrsocyrtis sp. of Foreman (1973), which is recorded as occurring in the early part of the Thyrsocyrtis triacantha lineage (Foreman, 1973). Cores 33 and 34 are assigned to the lower Eocene Buryella clinata Zone (and possibly the Bekoma bidarfensii Zone for Core 34) mainly on the presence of common Bekoma sp. and Buryella spp., as well as forms such as Lamptomium fabaeforme chaunothorax, Phormocyrtis cf. $P$. cubensis, Theocotyle cf. T. fimbria, T. cf. T. alpha, T. cf. T. cryptocephala nigriniae, Phormocyrtis striata, and others.

Mesozoic
On the basis of shipboard determinations, Cores 38
through 45, which span the interval from the lower vari-
colored clay unit into the upper part of the black clays,
are assigned to the Cenomanian. These poorly preserved
assemblages contain numerous spumellarians, but also
such recognizable forms as Dictyomitra formosa,
?Eusyringium typicum, Eucyrtidium grandis, ?Hemi-
cryptocapsa tuberosa, and Crucella sp. A (of Moore,
1973). In addition, Dictyomitra macrocephala, an easily
recognizable form in badly altered assemblages, occurs
in Cores 47,51 , and 62 . According to Moore the range
of this species is limited to upper Albian and lower
Cenomanian. In the present section, it has a well-
defined range from Core 62 up to Core 47 in the lower
part of the black clays, but it does not occur with the
typically lower Cenomanian assemblages of Cores 39
through 45 . Owing to the somewhat equivocal identifi-
cation of these assemblages, however, the upper limit of
D. macrocephala is here used provisionally to separate
lower from upper Cenomanian. No radiolarians were

found in Cores 63 to 65 which immediately overlie basalt (Core 66).

\section{SEDIMENT ACCUMULATION RATES}

The age versus depth plot for Site 386 is given in Figure 19. Sedimentation at Site 386 commenced with the deposition of a 240-meter-thick unit of greenish gray and dark gray and black claystones, which accumulated at a rate of about $16 \mathrm{~m} / \mathrm{m} . \mathrm{y}$. This is about an order of magnitude faster than purely pelagic accumulation rates for non-biogenic material, and as this unit is less than one-third composed of biogenic material, it suggests some introduction of material by other than pelagic mechanisms alone.

These claystones are succeeded by a short transition zone (Core 41) and then by zeolitic and multicolored (red) claystones. The zeolitic claystones accumulated at about the same rate as the underlying reduced claystones and may be linked with them in terms of depositional process. However, if the zeolites represent altered volcanic ash, they could indicate a component derived from an early phase of volcanism on Bermuda. A pronounced decrease in accumulation comes with the overlying red claystones, which accumulated at a pelagic rate of about $2.5 \mathrm{~m} / \mathrm{m}$.y. These represent deposition from the ?Turonian to the late Paleocene, although their inception is unknown (within the unfossiliferous interval between Cores 36 and 39). Whether these red claystones represent continuous accumulation is also unknown owing to the poor biostratigraphic data within this interval.

Another sharp break in sedimentation signals the beginning of accumulation of the 300-meter-thick lower and middle Eocene radiolarian mudstone, claystone, and turbidite sequence, which shows uniformly high accumulation rates of $20-40 \mathrm{~m} / \mathrm{m}$.y. These high rates accord well with the indication of high biological productivity during the deposition of this sequence as well as with its (in part) turbiditic origin.

Accumulation of the succeeding calcareous and volcanic turbidite sequence is marked by a reduction of accumulation rate to an average of about $9.5 \mathrm{~m} / \mathrm{m} . y$., with a sharp decrease to about $2 \mathrm{~m} / \mathrm{m}$.y. in the late middle Oligocene. This change in rate may mark the cessation of volcanic contribution from the Bermuda pedestal and a late Oligocene to early Miocene phase of slow pelagic and minor turbidite accumulation.

The few data points for the remaining Miocene and Pliocene suggest slow accumulation $(\sim 6 \mathrm{~m} / \mathrm{m}$.y.) of the clays and oozes that typify this part of the section. At some time, possibly close to the beginning of the Pleistocene, deposition of marly nannofossil ooze began. Piston cores from this area contain similar material, indicating that this depositional regime has continued to the present, with accumulation at rates of about $35 \mathrm{~m} / \mathrm{m}$.y.

\section{CORRELATION OF SEISMIC PROFILE WITH DRILLING RESULTS}

Detailed seismic surveys were conducted aboard USNS Kane and Wilkes in the vicinity of Site 386 during 1974. These data show that sediment thickness in the 


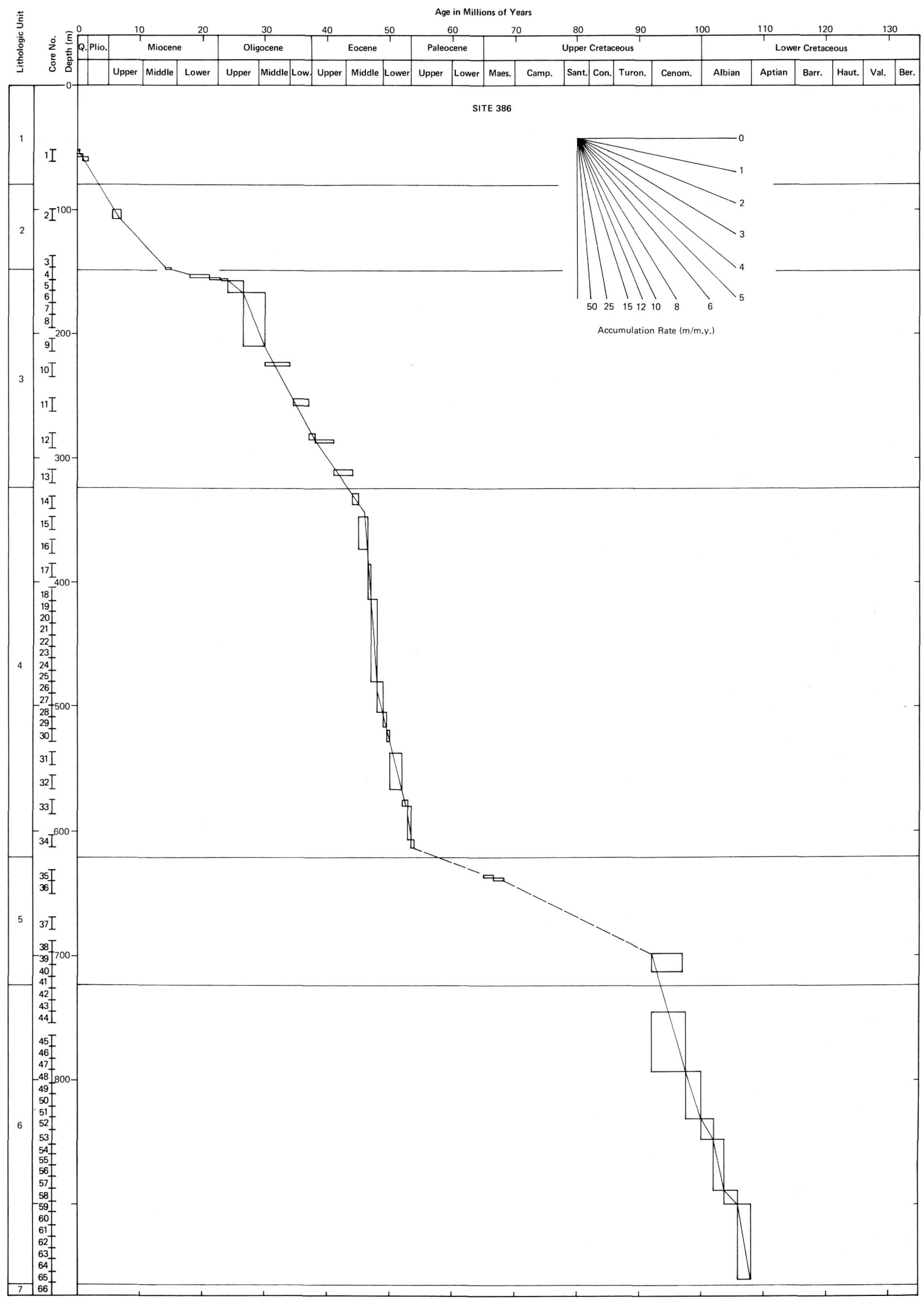

Figure 19. Sediment accumulation rates, Site 386. 
area is controlled in large part by the basement topography, which exhibits general west-northwest and northnortheast trends (see Bowles, this volume). Most of the reflectors known in this region are observed in the thick sediment pockets filling basement depressions (Figure 20).

Four prominent reflectors are observed in profiler data; the upper reflector is single and overlies a deeper pair of reflectors. These three reflectors have previously been grouped under the heading "Horizon $A$." The shallowest reflector merges with the acoustically opaque apron of the Bermuda Pedestal; thus it appears to be closely linked with the volcanic/denudation history of Bermuda.

The fourth, deeper reflector is Horizon $A^{*}$. This acoustic horizon was tentatively correlated with the transition from multicolored clays into underlying Cretaceous black clays at Site 105 (Ewing and Hollister, 1972). Horizon $A^{*}$ is observed in this part of the Bermuda Rise only in the deepest basement depressions, where it lies about 0.6-0.8 sec sub-bottom (Figures 2, 21, 23).

The results of drilling at Site 386 and the inferred correlations with the seismic section in the Challenger records are shown in Figures 21 and 22. The lateral depth variability of the reflectors near Site 386 unfortunately is quite pronounced, thus making precise lithologic/seismic correlations difficult. It is also difficult to pick reflector depths in the Challenger records because the ringing pulse in the low-frequency recording (required for acoustic penetration to basement) masks and confuses reflectors (Figure 23). The best profiler record across Site 386 is that taken when Challenger departed from the site, and an interpretative tracing of this record is shown in Figure 21.

Reflector 1 (Figure 21) clearly corresponds to the first downhole occurrence of coarse, high-velocity sands recovered about 170 meters sub-bottom near the top of the sequence of Oligocene volcaniclastic turbidites (Figure 22). This reflector can be traced north to where it merges with the acoustically opaque Bermuda Pedestal. It is so strongly reflective that it mostly masks the underlying "Horizon $A$ " reflectors at Site 386; however, the profiler record between Sites 386 and 387 shows that the reflector diminishes in intensity to the west and ultimately fades out, leaving the underlying reflectors easily detectable. The acoustic degeneration of the reflector away from Bermuda is consistent with the expected diminution of coarse, reflective, volcaniclastic debris in areas distant from the island. Because of its association with the "Horizon- $A$ complex" and because of its genesis, this reflector is termed Horizon $A^{v}$ for the volcaniclastic turbidites it represents (Tucholke, this volume). The calculated interval velocity between the sea floor and Horizon $A^{v}$ is $1.74 \mathrm{~km} / \mathrm{sec}$, about 12 per cent higher than the average of shipboard measurements for this interval (Figure 22). This difference is comparable to that commonly determined for the upper few hundred meters of unconsolidated sediments in DSDP holes (Houtz, 1975).

Reflector 2, which is the upper of the reflector pair commonly observed on the Bermuda Rise, appears to correlate with the velocity inversion where upper-middle

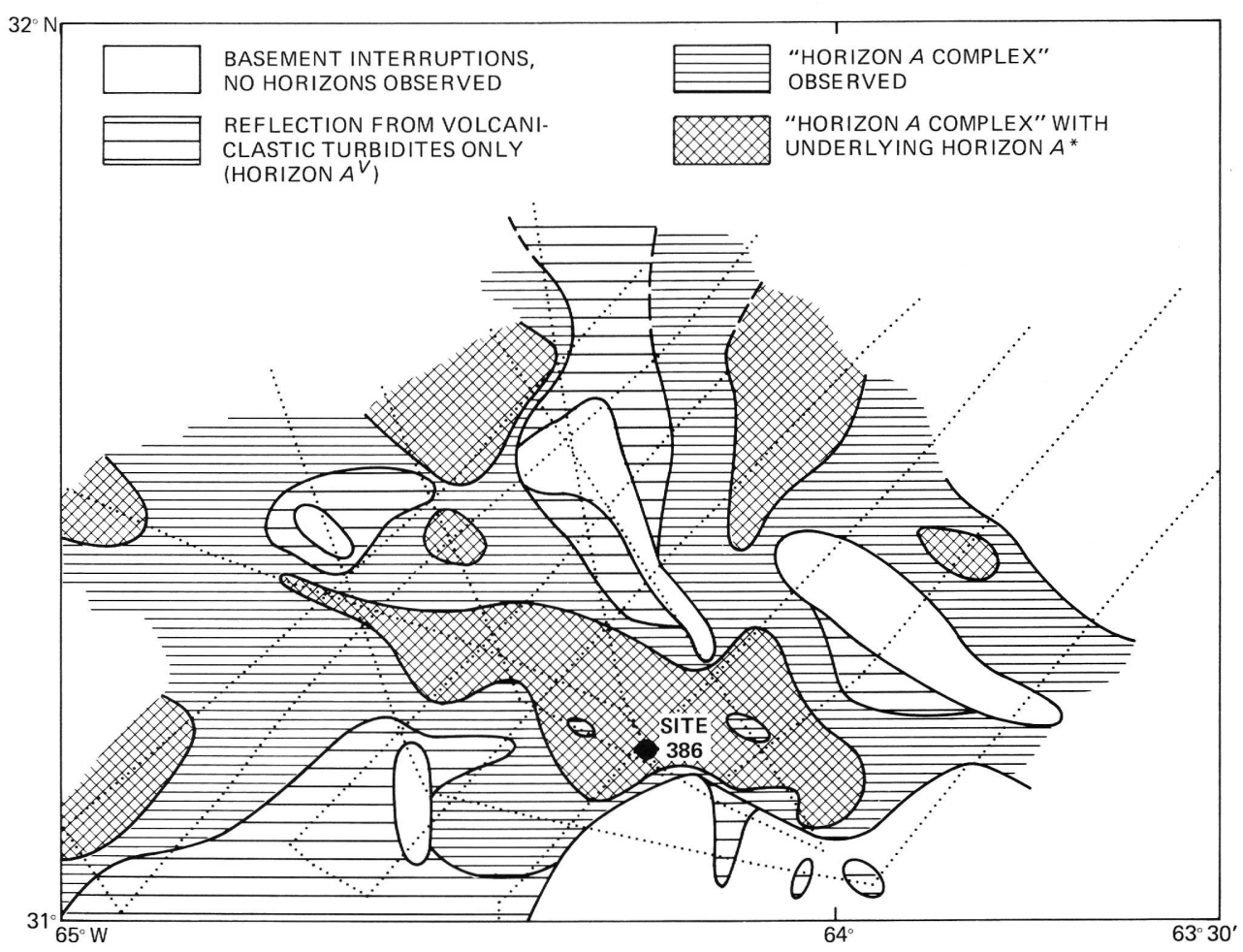

Figure 20. Distribution of seismic horizons around Site 386. "Horizon-A complex" includes Horizons $\mathrm{A}^{\mathrm{V}}, \mathrm{A}^{\mathrm{T}}$, and $\mathrm{AC}^{\mathrm{C}}$ (see text). Track control shown by dotted lines. 


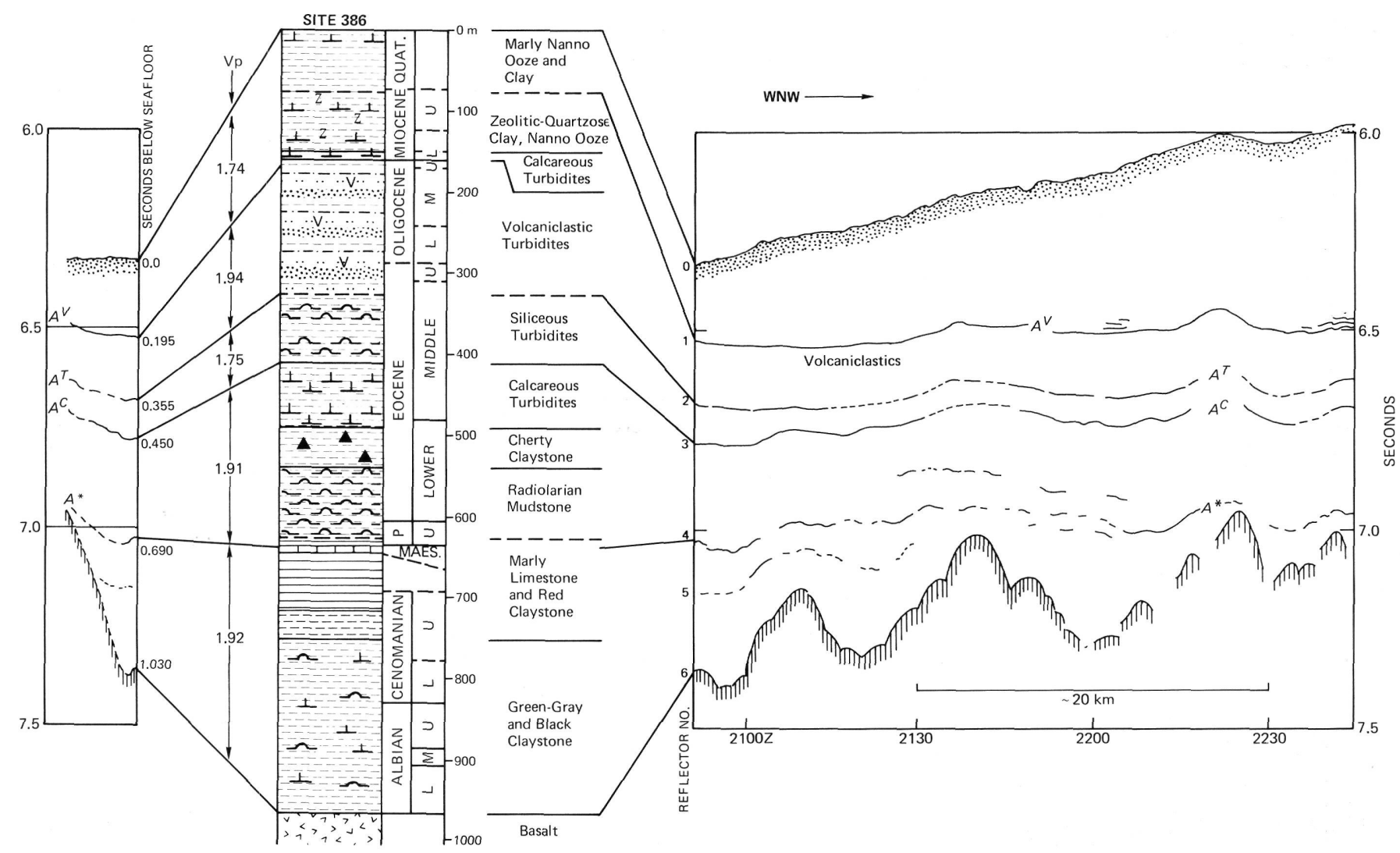

Figure 21. Correlation of Challenger seismic profile and lithology at Site 386.

Eocene volcaniclastic turbidites overlie middle Eocene siliceous turbidites (Figure 22). The contact lies in the uncored interval between Cores 13 and 14 (348.5$328.0 \mathrm{~m}$ ) and is assumed to occur at 325 meters. This reflector is termed Horizon $A^{T}$ for its association with the top of fine-grained siliceous turbidites in the "Horizon- $A$ complex" (Tucholke, this volume). Although it is widespread on the Bermuda Rise, Horizon $A^{T}$ is usually much less reflective than the paired reflector beneath it, and because of its proximity to the deeper reflector (about 0.1-0.2 sec), Horizon $A^{T}$ often cannot be differentiated in low-frequency profiler records which have a complex signal pulse. The calculated interval velocity between Horizons $A^{v}$ and $A^{T}$ is $1.94 \mathrm{~km} / \mathrm{sec}$ which, like the shipboard measurements, reflects the sharply increased compressional wave velocity in the volcaniclastic sands.

Reflector 3 can be traced seismically to DSDP Sites 6 , 7 , and 387, where it correlates with upper-lower to lower-middle Eocene chert (Ewing, et al., 1970; Site 387 Report). This reflector is called Horizon $A^{C}$ for its typical association with Eocene chert (Tucholke, this volume). However, it is apparent that at Site 386 , Horizon $A^{c}$ correlates with the top of middle Eocene calcareous turbidites about 408 meters sub-bottom which overlie and mask the lower to middle Eocene cherts about 82 meters deeper (Figure 22). It appears that the rapid emplacement of calcareous detritus from the adjacent topographic highs into the fracture valley where Site 386 was drilled accounts for the presence of the calcareous turbidites, but Horizon $A^{C}$ shows no variations which would indicate their atypical occurrence. Thus Site 386 provides a good example of the limitations of profiler data in predicting local lithofacies. The calculated interval velocity between Horizons $A^{T}$ and $A^{C}$ is $1.75 \mathrm{~km} / \mathrm{sec}$ and is 6 per cent higher than the average of shipboard measurements.

Reflector 4 is not well defined at Site 386 , but it can be traced to the western Bermuda Rise where it correlates with Horizon $A^{*}$ (Tucholke, this volume). The only marked velocity/impedance contrast measured on samples from this general level in the hole occurs in Core 35 near 636 meters sub-bottom at the top of Maestrichtian marly limestones (Figures 21, 22). Correlation of this impedance contrast with Horizon $A^{*}$ provides an interval velocity of $1.91 \mathrm{~km} / \mathrm{sec}$ between Horizons $A^{C}$ and $A^{*}$. This compares favorably with measured velocities (Figure 22). Similarly, the calculated interval velocity of $1.92 \mathrm{~km} / \mathrm{sec}$ between Horizon $A^{*}$ and basement (964.2 m sub-bottom) also agrees with shipboard measurements on core samples.

The correlation of Horizon $A^{*}$ to the surface of marly limestones that occur near the top of the multicolored claystones suggests that most of the Horizon $A^{c}$ to $A^{*}$ interval consists of pelagic, siliceous, and calcareous sediment of Paleocene and Eocene age. The apparent discrepancy in lithologic correlation between this interpretation and the Leg 11 correlation of Horizon $A *$ with the multicolored clay/black clay transition at Site 105 (Ewing and Hollister, 1972) can be resolved by closer ex- 


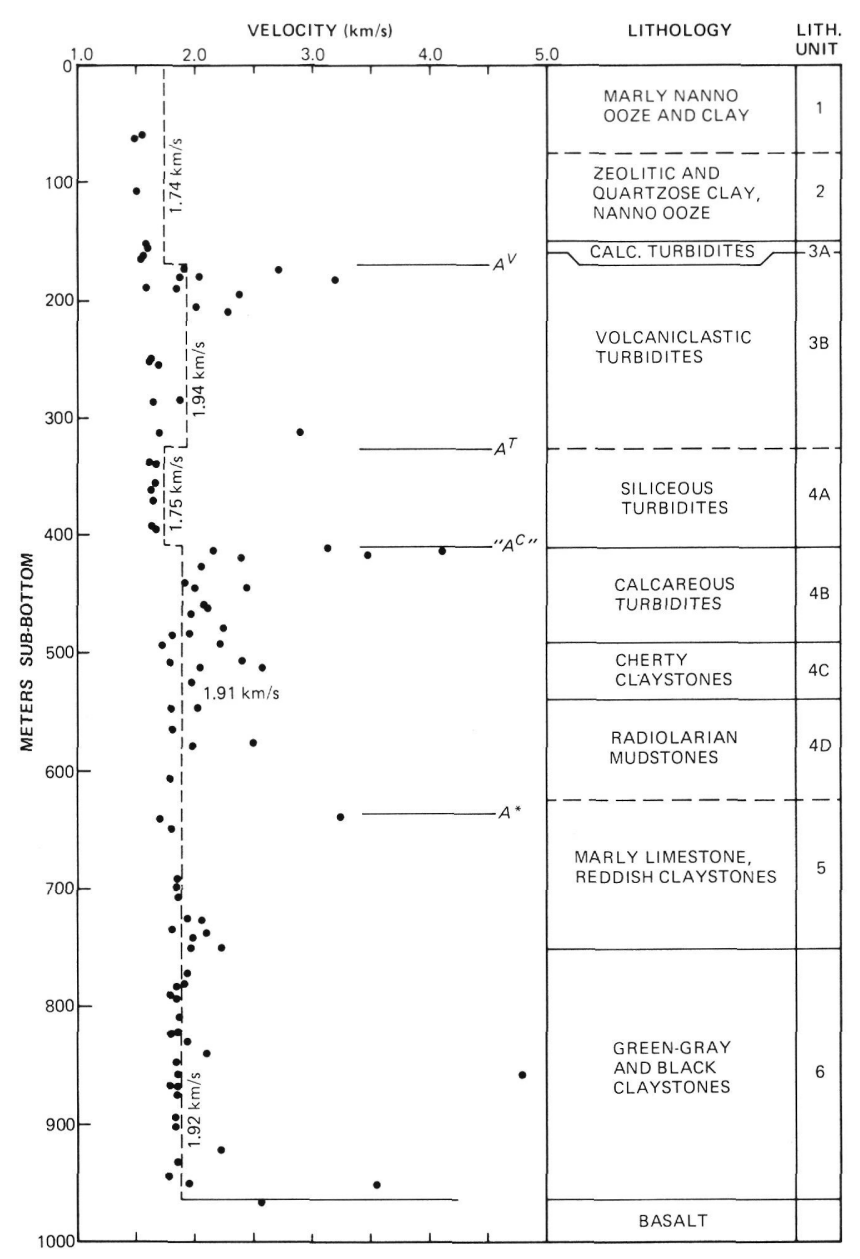

Figure 22. Velocities of samples measured directly with the Hamilton-frame velocimeter (dots) and calculated interval velocities (dashed lines) at Site 386.

amination of the Site 105 drilling results and seismic record. No cores were taken at Site 105 between 193 meters (upper Miocene clay) and 241 meters (undated multicolored clay, probably Upper Cretaceous). This unsampled 48-meter interval could well contain Maestrichtian chalks such as those correlative to Horizon $A^{*}$ at Site 386, as well as younger, Paleocene and possibly Eocene sediments; the thickness of the "Horizon $A$ " to $A *$ interval at Site 105 is less than $0.05 \mathrm{sec}$ (i.e., less than $45 \mathrm{~m}$ at $1.8 \mathrm{~km} / \mathrm{sec})$. One additional piece of evidence suggests that Horizon $A^{*}$ may represent the top (rather than the bottom) of the multicolored clays; at Site 7 (Leg 1) a sparsely sampled section encountered the multicolored clays immediately below ( $\sim 42 \mathrm{~m}$ ) Horizon $A^{c}$. Close examination of unpublished profiler data taken by Lamont-Doherty in a subsequent detailed survey around Sites 6 and 7 shows that Horizon $A^{*}$ shoals and merges with Horizon $A^{C}$ at the location of Site 7, so that drilling there penetrated both horizons.

Reflector 5, between Horizon $A^{*}$ and basement, is poorly defined in the Challenger profile, and is only of local extent. It lies near the depth of the multicolored clay/black clay transition, about 725 meters sub-bottom, but shipboard velocity/impedance measurements on samples from this depth do not show a clear-cut contrast which can be correlated to the reflector (Figure 22).

\section{SUMMARY AND CONCLUSIONS}

Site 386 was drilled in 4783 meters of water to a subbottom depth of 973.8 meters, penetrating 964.2 meters of sediments and about 9.6 meters of underlying basement basalt (Figure 4). The site was located $140 \mathrm{~km}$ south-southeast of Bermuda on the southern edge of a fracture valley, in the "Cretaceous quiet zone." Magnetic anomaly $M-0$ of the Keathley Sequence lies about $90 \mathrm{~km}$ west-northwest of Site 386 . The upper 62 meters were discontinuously cored, but from there to basement a fairly continuous record was obtained. Sixty-six cores were taken, more than at any previous drill site in the western North Atlantic. Principal objectives included the dating and lithologic identification of the major acoustic reflectors in the "Horizon- $A$ complex" (see Tucholke, this volume) and Horizon $A^{*}$, and the relation between these and the prominent "Bermuda reflector" that merges into the acoustically opaque Bermuda apron. Other objectives included determining the age and extent of the red clay and black clay facies previously cored in the western Atlantic, and establishing the age of basement.

Of the total of 66 cores attempted, representing 64 per cent of the depth drilled, 438.2 meters of core were recovered. All the major objectives of this site were met.

\section{The Record of Bermuda Volcanism at Site 386}

The age of the volcanic pedestal beneath Bermuda has long been in doubt and recent drilling on Bermuda has provided new constraints (Reynolds and Aumento, 1974; Aumento and Gunn, in press). In this discussion we include Challenger and Plantagenet banks southwest of the main Bermuda edifice, and Bowditch Seamount to the northeast, when we speak of "Bermudan volcanism." We assume without definite proof that all four features were produced during the same episode and do not differ greatly in age.

Although Site 386 was considerably farther $(140 \mathrm{~km})$ from Bermuda than Sites 382 and 385 were from the nearest New England seamounts, the site was expected to yield a record of Bermudan volcanism because a reflector (Horizon $A^{V}$ ) merging with the Bermuda volcanic apron can be traced to the site. The topography of the present sea floor seems ideally suited to channel turbidity currents from Bermuda to the fracture valley in which Site 386 is located, and the sea-floor topography at the time Horizon $A^{V}$ was deposited probably was not much different (Bowles, unpublished data). Volcaniclastic turbidites (lithologic Sub-unit 3B) were cored at the level of Horizon $A^{v}$, and overlying calcareous turbidites (Sub-unit 3A) have volcaniclastic components decreasing upward in significance. Because Site 386 is near Bermuda and because similar volcaniclastic turbidites do not occur at substantially greater distances from Bermuda, we infer that the turbidites are of Bermudan origin. 


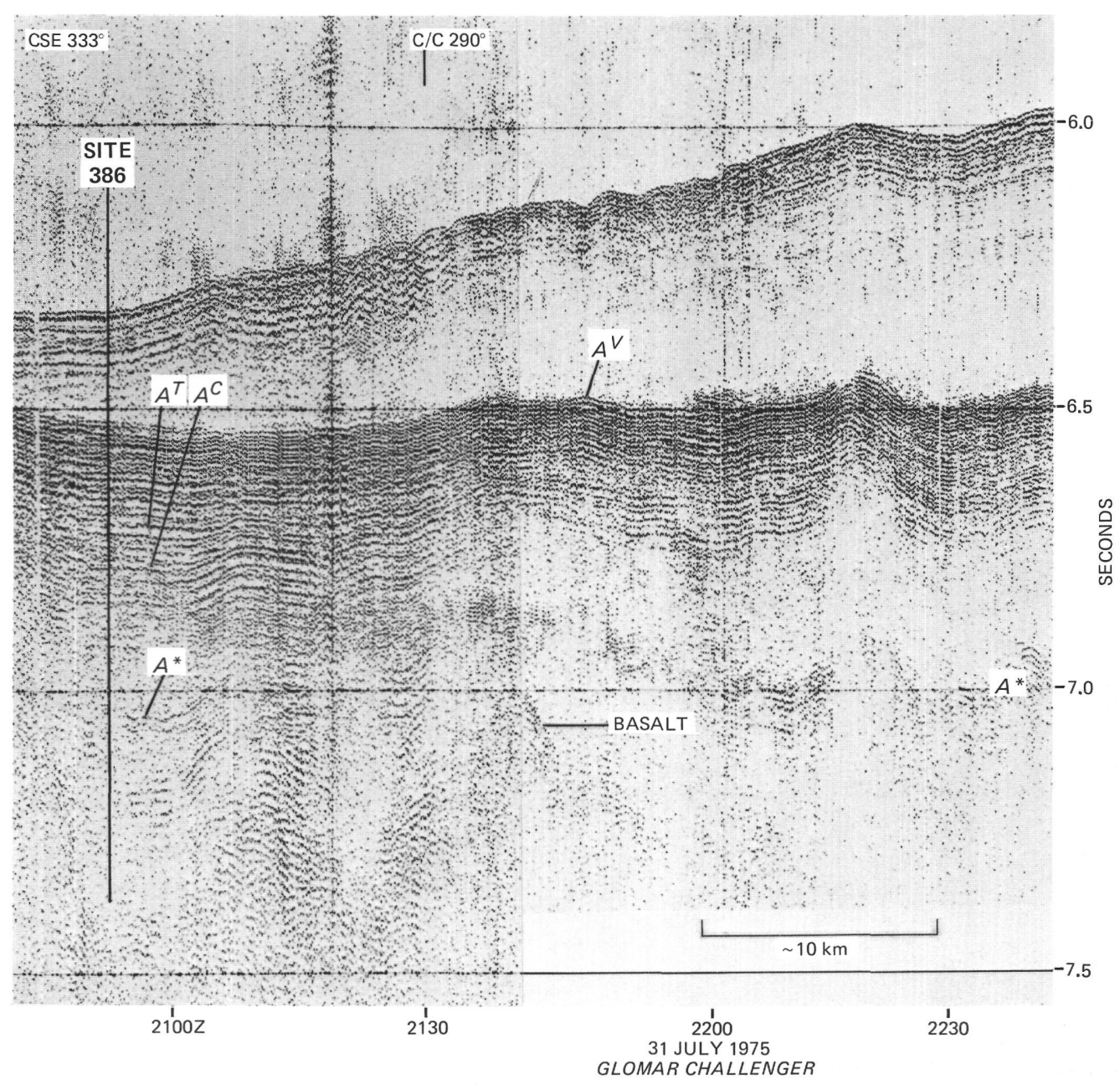

Figure 23. Challenger seismic profile recorded when departing Site 386. Location in Figure 3.

Except for upper Cenomanian zeolitic claystones in lithologic Unit 5 that possibly are of volcanogenic origin (discussed below), the earliest record of Bermudan volcanism occurs in the late middle to early late Eocene (46-42 m.y.B.P.) in Core 13 at the base of lithologic Sub-unit 3B. The Sub-unit 3B volcaniclastic turbidites extend up through Core 5 (318.5 to $157 \mathrm{~m}$ sub-bottom), and they consist primarily of heavy minerals, opaques, and mica, with relatively little ash, pumice, or basalt fragments. Thus the turbidity flows were not generated directly as a result of volcanism; rather they incorporated detrital (phenocryst) residues from "subtropical" erosion of volcanic source rocks. However, the relatively fresh appearance of the mineral grains suggests that they were quickly discharged into the Atlantic with little residence time on the islands. We have no information on the time it took the Bermuda volcanoes to reach sea level, but it is unlikely that the period exceeds a few million years (Vogt and Tucholke, this volume); once having reached wave base, the volcanoes probably began to erode almost immediately, and little time would have elapsed before the first turbidites entered nearby submarine valleys. Thus the age at the base of the lithologic Sub-unit 3B probably provides a close ap- proximation of the time the volcanic edifice first emerged above sea level. The youngest core in which heavy mineral turbidites abound is Core 6, dated as middle Oligocene. Therefore, the emergent phase of Bermuda volcanism and erosion had ended by late Oligocene time.

The time span involved in the emergent phase could be as much as $20 \mathrm{~m}$.y. (46 to 26 m.y.B.P.) or as little as 10 m.y. (42-32 m.y.B.P.). Assuming smoothly varying sediment accumulation rates in the volcaniclastic turbidites at Site 386, the most likely duration is $15 \mathrm{~m} . \mathrm{y}$. (42 to 27 m.y.B.P.).

The thickest and coarsest volcaniclastic turbidites at Site 386 were emplaced during the middle Oligocene (34 to 29 m.y.B.P.). Their introduction to Site 386 may reflect either increased volcanism/erosion at Bermuda or simply maximum development of turbidite dispersal paths to the drill site. Thus it is not possible to clearly document whether the pre-middle Oligocene volcanism at Bermuda was episodic, but it is evident that volcanism and subsequent erosion to wave base were essentially complete at the end of the middle Oligocene. The erosion time probably was of the order 5 to $10 \mathrm{~m} . \mathrm{y}$. (Vogt, 1974). 
The uppermost Oligocene/lower Miocene turbidites at Site 386 (lithologic Sub-unit 3A; Core 4) are primarily carbonate but still contain appreciable altered ash, heavy minerals, opaques, and zeolites. These sediments apparently record the erosion of remaining volcanic outcrops and perhaps shallow-water limestones exposed by minor sea-level fluctuations. The altered ash may suggest minor, primarily explosive reactivation of Bermudan volcanism, but more detailed study is required to document the reality of such an episode. In Cores 1 to 3 (Pleistocene to [?]middle Miocene) no significant volcanogenic components are observed.

On Bermuda, igneous drill-hole chips were radiometrically dated by Gees (1969) at 34 and 52 m.y.B.P. Reynolds and Aumento (1974) determined an age of 33.5 $\pm 2 \mathrm{~m}$.y. for lamprophyric sheets which intruded older tholeiitic submarine lavas in the Deep Drill 1972 borehole; the lavas yielded questionable 48 and $91 \mathrm{~m} . \mathrm{y}$. ages. These data, together with the drilling results at Site 386, suggest that the Tertiary volcanism at Bermuda included (a) early(?) to middle Eocene submarine volcanism constructing the pedestal, (b) subaerial exposure and erosion near the end of the middle Eocene, perhaps with reduced volcanism or cessation of volcanism, (c) renewed volcanism and uplift/erosion early in the middle Oligocene, with intrusion of lamprophyre sheets, and (d) subsequent erosion to wave base. If Bermuda was like Hawaii, later eruptions of more alkalic or nephelenitic suites may have occurred without contributing substantially to the volume of the pedestal or to erosional debris displaced to Site 386.

A possible analogy between Bermuda and Hawaii has two other facets. First, the relatively small percentage of ash and the absence of discrete ash layers at both Sites 386 and 387 suggest primarily passive basalt flows on Bermuda rather than pyroclastic eruptions. Similarly, little ash is found in young sediments around Hawaii. Second, there is a morphologic resemblance between the main Bermuda edifice and known shield volcanoes; in this respect Bermuda is more similar to the Hawaiian Islands than the steep-sided volcanoes common elsewhere in the Atlantic, for example, the Azores and the New England seamounts. The shield shape again supports the model of primarily passive basalt flows (although archipelagic/volcaniclastic aprons may mask an initially steeper profile). Of course, Bermuda is not part of a volcanic chain like Hawaii, but the bearing of this difference on volcano morphology is unknown.

A major mineralogical problem is the substantial concentration of apparently muscovite mica found in the calcareous and volcaniclastic turbidites at Site 386. This material generally is not found in volcanic rocks of oceanic islands. The presence of muscovite could argue for a continental origin, but in that case quartz grains would be expected and quartz is rare in these sediments. The mica observed in smear slides may be phlogopite weathered out of lamprophyre sheets such as those encountered in the Deep Drill 1972 borehole on Bermuda. The occurrence of mica only in the latest turbidites of obvious Bermudan origin (beginning in the late middle Oligocene) suggests that the lamprophyre sheets either had not been intruded until late in the volcanic cycle or were not exposed by erosion of surrounding extrusives until late in the emergence history of the volcanic rocks. The former alternative is favored by the $33.5 \pm 2 \mathrm{~m} . \mathrm{y}$. age of lamprophyre sheets radiometrically dated by Reynolds and Aumento (1974).

There is some evidence for much earlier volcanism in the vicinity of Bermuda. A primarily upper Cenomanian bed of zeolitic claystones, 28.6 meters thick (Cores 38 to 40 ), probably includes the alteration products of volcanic ash. Glass shards suggest that this volcanism was primarily pyroclastic. Reynolds and Aumento (1974) and Aumento and Gunn (in press) have suggested that the tholeiitic, shield-building stage of Bermuda, represented by numerous pillow and subaerial lava flows encountered in their 1972 borehole on Bermuda, actually occurred 90-110 m.y.B.P. at the crest of the Cretaceous Mid-Atlantic Ridge. Two pillow lava samples gave rather uncertain ages of 48 and 91 m.y.B.P. Reynolds and Aumento (1974) suggest that the former date may represent alteration during dike intrusion and that the true age of these lavas is at least 90 m.y.B.P. If Bermudan volcanism was initiated this early, the upper Cenomanian (92-95 m.y.B.P.) zeolitic claystones recovered at Site 386 may correlate with the tholeiitic lava episode. There are two problems with this correlation: (1) the zeolitic claystones contain glass shards of high silica content, suggesting pyroclastic volcanism rather than low-viscosity, submarine tholeiite flows like those drilled on Bermuda; and (2) the great elevation of Bermuda above the surrounding oceanic basement would require an unreasonably great paleodepth of 4-5 km for the crest of the Mid-Atlantic Ridge if Bermuda formed near the spreading axis; of course, Bermuda may have been only partly constructed at and near the ridge crest during the Cretaceous (say between $M-0$ [108 m.y.] and the latest Cenomanian [92 m.y.]), but this leaves unexplained the mechanism by which the Cretaceous basalt flows subsequently were elevated some $2 \mathrm{~km}$ to near present sea level. Because many postassium-argon ages on pillow basalts are anomalously high, the 91 m.y.B.P. age reported by Reynolds and Aumento (1974) may be spurious, and the 48 m.y.B.P. more reasonable. The latter age then would date the initial construction of Bermuda as a tholeiite shield, not the alteration of 90-110 m.y. lavas by lamprophyre dikes.

\section{Calcareous and Siliceous Turbidites}

At Site 386, as at Sites 6, 7, and 387, the lower and middle Eocene section is characterized by rapidly deposited cyclic sedimentary sequences, occurring directly below the volcaniclastic turbidites discussed above. Sediments containing these cyclic sequences at Site 386 are at least 161.8 meters thick; they are subdivided on the basis of composition into two sub-units of about equal thickness, termed siliceous turbidites (lithologic Sub-unit 4A) and calcareous turbidites (4B). The cyclic sequences are of the order of 0.3 to 3 meters thick, and they ideally can be divided into five sublayers: $\alpha, \beta, \gamma, \delta$, and $\epsilon$, from bottom to top. These sublayers correspond roughly to intervals of the classic 
Bouma sequence (Bouma, 1962); their composition and characteristics are given in the Lithology section and by McCave (this volume). Based on the cyclic variation in sedimentary structures, the megascopic texture, and on subtle size-grading within the cycles, it is apparent that these cycles represent fine-grained turbidites of dominantly pelagic composition. Similar cycles are much more poorly defined in the immediately underlying lithologic sub-units (4C, cherty claystones; and 4D, radiolarian mudstones), but these sub-units probably also are of dominantly turbiditic origin. The entire Unit 4 sequence accumulated at very rapid rates averaging 20 to $40 \mathrm{~m} / \mathrm{m}$.y.

It is uncertain whether these turbidites are of purely local origin or whether they may include detritus from distant sources. The location of Site 386 in a fracture valley surrounded by steep scarps strongly suggests that much of the material is locally derived. On the other hand, similar turbidites accumulated at similar rates at Sites 387, 6, and 7 on the western Bermuda Rise where the adjacent sea floor morphology was smooth enough to preclude local derivation of such thick turbidites. The turbidites at these sites are thought to have been derived from the North American continental margin, and they may have reached as far as Site 386 . In modern analogs, turbidity currents probably originating on the Amazon Cone along the South American continental margin have reached comparable distances $(\sim 1000 \mathrm{~km})$ and entered the Vema Fracture Zone in the Mid-Atlantic Ridge (Bader et al., 1970), and sediments transported at least $1600 \mathrm{~km}$ from the North American continental margin have been deposited as distal, mostly clayey turbidites in fracture zones at the eastern end of the Nares Abyssal Plain. The top of the Eocene siliceous turbidites (Horizon $A^{T}$ ) can be traced in seismic profiles across the western Bermuda Rise to Site 386 , and the reflector is thought to represent the latest turbidites deposited before regional uplift formed the Bermuda Rise in the middle to late Eocene (Tucholke, this volume). Comparison of the present elevations of Horizon $A^{T}$ at Site 386 and above presumably normally subsided crust beneath the Hatteras Abyssal Plain suggests the central Bermuda Rise has been uplifted about 700 meters (Tucholke and Vogt, this volume). This uplift was coeval with or immediately followed by volcanism at Bermuda and presumably is related to that volcanism.

The paucity of obviously continental material such as detrital quartz in these turbidites would seem to argue against a provenance along the North American continental margin. However, because Site 386 represents such a distal facies, it is likely that the continental material was strongly diluted by pelagic debris entrained along the path of the turbidity currents. Despite the often significant carbonate in these turbidites, it is clear they were deposited below the contemporary CCD. The $\gamma$ and $\delta$ sublayers, which probably were deposited as part of the turbidites, are rich in carbonate, but the overlying, presumably pelagic $\epsilon$ sublayers are virtually carbonate free.

The cherty claystones (Sub-unit 4C) are widespread in North Atlantic drill sites. However, the localiza- tion of the porcelanitic chert within a much thicker siliceous/calcareous section is puzzling. It appears likely that productivity of siliceous organisms in surface waters increased markedly during the late early and early middle Eocene, or that increased silica in the bottom water enhanced preservation at the sea floor, or both.

\section{Multicolored Claystones}

The composition, textural uniformity, and low accumulation rates of the "red" claystones indicates that they are essentially pelagic deposits that accumulated well below the CCD. Locally abundant volcanogenic components that would be strongly diluted or masked in more rapidly accumulated sediments are strikingly evident in this facies. Middle to late Maestrichtian depression of the CCD is indicated by a marly limestone bed within the claystones, and this event is confirmed by recovery of similar calcareous beds at Sites 385 and 387 (Tucholke and Vogt, this volume).

\section{Black and Green-Gray Claystones}

The "black clays" at Site 386 extend from 724 meters to the top of basalt at 964 meters sub-bottom. Their primary characteristics are (1) alternation of green-gray burrowed and black non-burrowed sediments, (2) local calcareous beds, most of which appear to be turbidites, (3) radiolarian sand beds, 0.5 to $3 \mathrm{~cm}$ thick, that commonly occur within the black beds, and (4) locally high values of organic carbon (up to $14.3 \%$ ).

The black beds appear to owe their color to the presence of finely disseminated pyrite. Three factors suggest that these beds represent deposition beneath anoxic bottom water rather than purely intrasediment reducing conditions: (1) the black beds are not burrowed, (2) there is no correlation between sediment blackness and organic carbon content, and (3) there is more sulfur in the sediment than can be accounted for by reduction of sulfate in interstitial pore waters, and reduction of sulfate in overlying stagnant bottom water seems to be required (see Kendrick, this volume).

The green-gray and dark gray interbeds commonly are burrowed and probably were deposited beneath relatively oxygenated bottom water, although intrasediment reducing conditions may have prevailed. The cyclic alternation of these sediments and the black layers may record variations in surface-water productivity (organic carbon influx) and bottom water oxygenation (McCave, this volume), possibly acting independently of one another (Tucholke and Vogt, this volume). The frequency of these cycles in Core 44 suggests periodicities of the order $2 \times 10^{4}$ years, perhaps controlled in some way by $1.9 \times 10^{4}$ and $4.1 \times 10^{4}$ obliquity periodicities in global insolation (McCave, this volume). The radiolarian sand layers tend to be more common in the black layers and most do not appear to be graded; they may represent peak productivity cycles extending over many years.

The calcareous beds that interrupt the black clay sequence are most common in Cores 48 to 59, and at least below Core 50 they commonly are graded and probably are turbidites comprised of pelagic detritus that slumped 
from adjacent peaks. From this interpretation we infer that deposition at Site 386 was below the CCD and beneath intermittently anoxic bottom water, while the surrounding peaks, rising 1600 meters and more above the contemporary Site $\mathbf{3 8 6}$ sea floor, were accumulating carbonate above the CCD. If the top of basement at Site 386 is "backtracked" along the normal crustal subsidence curve, and an isostatic correction for sediment loading and a 700-meter correction for uplift of the Bermuda Rise are applied, an original crustal depth of about $\mathbf{3 2 0 0}$ meters is indicated. Thus euxinic conditions within the water column extended up to at least 3200 meters, and the CCD probably was between 1600 and 3200 meters (see Tucholke and Vogt, this volume). Thiede and van Andel (1977) suggested that at least some of the black clay deposition in the South Atlantic was beneath an oxygen-minimum layer. However, in the western North Atlantic, black clays were deposited on much older, deeper crust (Sites 387, 101, 105) coevally with the black clays at Site 386 , and anaerobic conditions below 3200 meters throughout the entire basin are indicated.

Further discussions about the conditions of black clay deposition, the cyclicity of deposition, and the events that may have triggered the basinwide stagnation are given by Kendrick; McCave; and Tucholke and Vogt (all this volume).

\section{The Basaltic Basement}

Drilling rates suggest that igneous basement was reached at a sub-bottom depth of 966.2 meters, 2 meters into Core 66; penetration to 973.8 meters resulted in recovery of 1.9 meters of basalt. The contact with the overlying sediments was not recovered, nor were any baked sediments observed. The basalt, although somewhat altered, is typical of basalts found on the present-day mid-oceanic ridge. Sediments in Section 1 of Core 65 immediately overlying the basalt are of early Albian age (105-108 m.y.B.P.). Because Site 386 was drilled near the axis of a deep fracture valley, it is unlikely that substantially older sediments occur nearby, and the early Albian age probably accurately dates the formation of the crust.

The basement age appears to confirm the midCretaceous fast-spreading episode first postulated by Larson and Pitman (1972). Along the flow line passing through Site 386 , the average spreading half-rate between anomaly 25 and the youngest anomalies of the Keathley Sequence was about $2.4 \mathrm{~cm} / \mathrm{yr}$ (Vogt et al., this volume). The principal remaining uncertainty in this estimate of average spreading rate is the absolute dating of the mid-Cretaceous stages. If these stages are actually 10 per cent older, say 110 versus 100 m.y.B.P., much of the "fast spreading" episode would disappear. It seems unlikely, however, that the stratigraphic time scales recently published (van Hinte, 1976) are this far in error.

\section{Intervals of Reversed Magnetization in the Albian}

Remanent magnetization of the sediments at Site $\mathbf{3 8 6}$ (Keating and Helsley, this volume) indicates that several reversed intervals occurred during the Albian. Because Site 386 is located on crust younger than anomaly $M-0$, these reversed intervals occurred during the "long Cretaceous normal" or "Mercanton" period. These or similar reversed intervals, although short $\left(\sim 10^{4}\right.$ to $10^{5}$ years), have been found at other DSDP sites and must be part of the geomagnetic polarity history. At the midCretaceous spreading half-rates inferred for this region, the corresponding reversely magnetized crustal strips would be as much as 1 or $2 \mathrm{~km}$ wide, enough to contribute to the relatively high amplitude magnetic anomalies found in the "Mercanton" period (Vogt and Johnson, 1971; Vogt and Einwich, this volume).

\section{REFERENCES}

Aumento, F. and Gunn, G., in press. Deep Drill-1972: Petrology and geochemistry of the Bermuda Seamount, J. Petrology.

Bader, R. G., Gerard, R. D., et al., 1970. Initial Reports of the Deep Sea Drilling Project, v. 4: Washington (U.S. Government Printing Office).

Beall, A. O., Jr. and Fischer, A. G., 1969. Sedimentology. In Ewing, M., Worzel, J. L., et al., Initial Reports of the Deep Sea Drilling Project, v. 1: Washington (U.S. Government Printing Office), p. 521-593.

Berger, W. H. and von Rad, U., 1972. Cretaceous and Cenozoic sediments from the Atlantic Ocean. In Hayes, D. E., Pimm, A. C., et al. Initial Reports of the Deep Sea Drilling Project, v. 14: Washington (U.S. Government Printing Office), p. 787-954.

Blow, W. H., 1969. Late middle Eocene to Recent planktonic foraminiferal biostratigraphy. In Brönnimann, P. and Renz, H. H. (Eds.), Int. Con'f. Plankt. Microfossils, First Proc.: Leiden (E. J. Brill), p. 199-421.

Bouma, A., 1962. Sedimentology of some flysch deposits; a graphic approach to facies interpretation: Amsterdam (Elsevier), p. 168.

Bryan, W. B., 1972. Textural and mineralogical relations of basalts from Sites 100 and 105. In Hollister, C. D., Ewing, J. I., et al., Initial Reports of the Deep Sea Drilling Project, v. 11: Washington (U.S. Government Printing Office), p. 873-876.

Ericson, D. B. and Wollin, G., 1968. Pleistocene climates and chronology in deep-sea sediments, Science, v. 162, p. 1229-1234.

Ewing, J. and Hollister, C., 1972. Regional aspects of deep-sea drilling in the western North Atlantic. In Hollister, C. D., Ewing, J. I., et al., Initial Reports of the Deep Sea Drilling Project, v. 11: Washington (U.S. Government Printing Office), p. 951-973.

Ewing, J. and Tirey, P., 1961. Continuous seismic profiler, J. Geophys. Res., v. 66, p. 2917-2927.

Ewing, J., Windisch, C., and Ewing, M., 1970. Correlation of Horizon A with JOIDES bore-hole results, J. Geophys. Res., v. 75, p. 5645-5653.

Ewing, J., Worzel, J., Ewing, M., and Windisch, C., 1966. Ages of Horizon A and the oldest Atlantic sediments, Science, v. 154, p. 1125-1132.

Ewing, M., Worzel, J. L., et al., 1969. Initial Reports of the Deep Sea Drilling Project, v. 1: Washington (U.S. Government Printing Office).

Foreman, H. P., 1973. Radiolaria of Leg 10 with systematics and ranges for the familiar Amphipyndacidae, Artostrobiidae, and Theoperidae. In Worzel, J. L., Bryant, W., et al., Initial Reports of the Deep Sea Drilling Project, v. 10: 
Washington (U.S. Government Printing Office), p. 407-474.

Gees, R. A., 1969. The age of the Bermuda Seamount, Maritime Sediments, v. 5, p. 56-57.

Hay, R. L., 1966. Zeolites and zeolitic reactions in sedimentary rocks, Geol. Soc. Am. Spec. Paper 85, p. 1-130.

Hays, J. D. and Pitman, W. C., III, 1973. Lithospheric plate motion; sea level changes and climatic and ecological consequences, Nature, v. 246, p. 18-22.

Hermes, J. J., 1969. Late Albian Foraminifera from the subbetic of southern Spain, Geol. Mijnbouw, v. 48, p. 35-65.

Hollister, C. D., Ewing, J. I., et al., 1972. Initial Reports of the Deep Sea Drilling Project, v. 11: Washington (U.S. Government Printing Office).

Houtz, R. E., 1975. Comparison of sonobuoy and sonic probe measurements with drilling results. In Kennett, J. P. Houtz, R. E., et al., Initial Reports of the Deep Sea Drilling Project, v. 29: Washington (U.S. Government Printing Office), p. 1123-1131.

Lancelot, Y. Hathaway, J. C., and Hollister, C. D., 1972. Lithology of sediments from the western North Atlantic, Leg 11, Deep Sea Drilling Project. In Hollister, C. D., Ewing, J. I., et al., Initial Reports of the Deep Sea Drilling Project, v. 11: Washington (U.S. Government Printing Office), p. 901-949.

Larson, R. L. and Pitman, W. C., 1972. World-wide correlation of Mesozoic magnetic anomalies, and its implications, Geol. Soc. Am. Bull., v. 83, p. 3645-3662.

Moore, T. C., Jr., 1973. Radiolaria from Leg 17 of the Deep Sea Drilling Project. In Winterer, E. L., Ewing, J. I., et al., Initial Reports of the Deep Sea Drilling Project, v. 17: Washington (U.S. Government Printing Office), p. 797-869.

Müller, G. and Gastner, M., 1971. The "Karbonat-Bombe," a simple device for the determination of the carbonate content in sediments, soils, and other materials, N. Jb. Mineral., Mh., v. 10, p. 466-469.
Peterson, M. N., Edgar, N. T., et al., 1970. Initial Reports of the Deep Sea Drilling Project, v. 2: Washington (U.S. Government Printing Office).

Phleger, F. B., Parker, F. L., and Peirson, J. F., 1953. North Atlantic Foraminifera, Rept. Swedish Deep-Sea Exped., v. 7, p. 1-122.

Reynolds, P. H. and Aumento, F., 1974. Deep Drill 1972. Potassium-argon dating of the Bermuda drill core, Canadian J. Earth Sci., v. 11, p. 1269-1273.

Saito, T., Burckle, L. H., and Ewing, M., 1966. Lithology and paleontology of the reflective layer Horizon $\mathrm{A}$, Science, v. 154, p. 1173-1176.

Schneider, E., 1969. Geologic investigations in the western North Atlantic, Unpublished Ph.D. thesis, Columbia University.

Stevenson, F. J. and Cheng, C. N., 1972. Organic geochemistry of the Argentine Basin sediments: carbonnitrogen relationships and Quaternary correlations, Geochim. Cosmochim. Acta, v. 36, p. 653-671.

Thiede, J. and van Andel, T. H., 1977. The paleoenvironment of anaerobic sediments in the late Mesozoic South Atlantic Ocean, Earth Planet. Sci. Lett., v. 33, p. 301-309.

Tucholke, B. and Ewing, J., 1974. Bathymetry and sediment geometry of the Greater Antilles Outer Ridge and vicinity, Geol. Soc. Am. Bull., v. 85, p. 1789-1802.

van Hinte, J., 1976. A Cretaceous time scale, Am. Assoc. Petrol. Geol. Bull., v. 60, p. 498-516.

Vogt, P. R., 1974. Volcano height and plate thickness, Earth Planet. Sci. Lett., v. 23, p. 337-348.

Vogt, P. R. and Johnson, G. L., 1971. Cretaceous seafloor spreading in the western North Atlantic, Nature, v. 234, p. 22-25.

Vogt, P. R., Anderson, C. N., and Bracey, D. R., 1971. Mesozoic magnetic anomalies, sea-floor spreading, and geomagnetic reversals in the southwestern North Atlantic, J. Geophys. Res., v. 76, p. 4796-4823.

Windisch, C., Leyden, R., Worzel, J., Saito, T., and Ewing, J., 1968. Investigation of Horizon Beta, Science, v. 162, p. 1473-1479. 

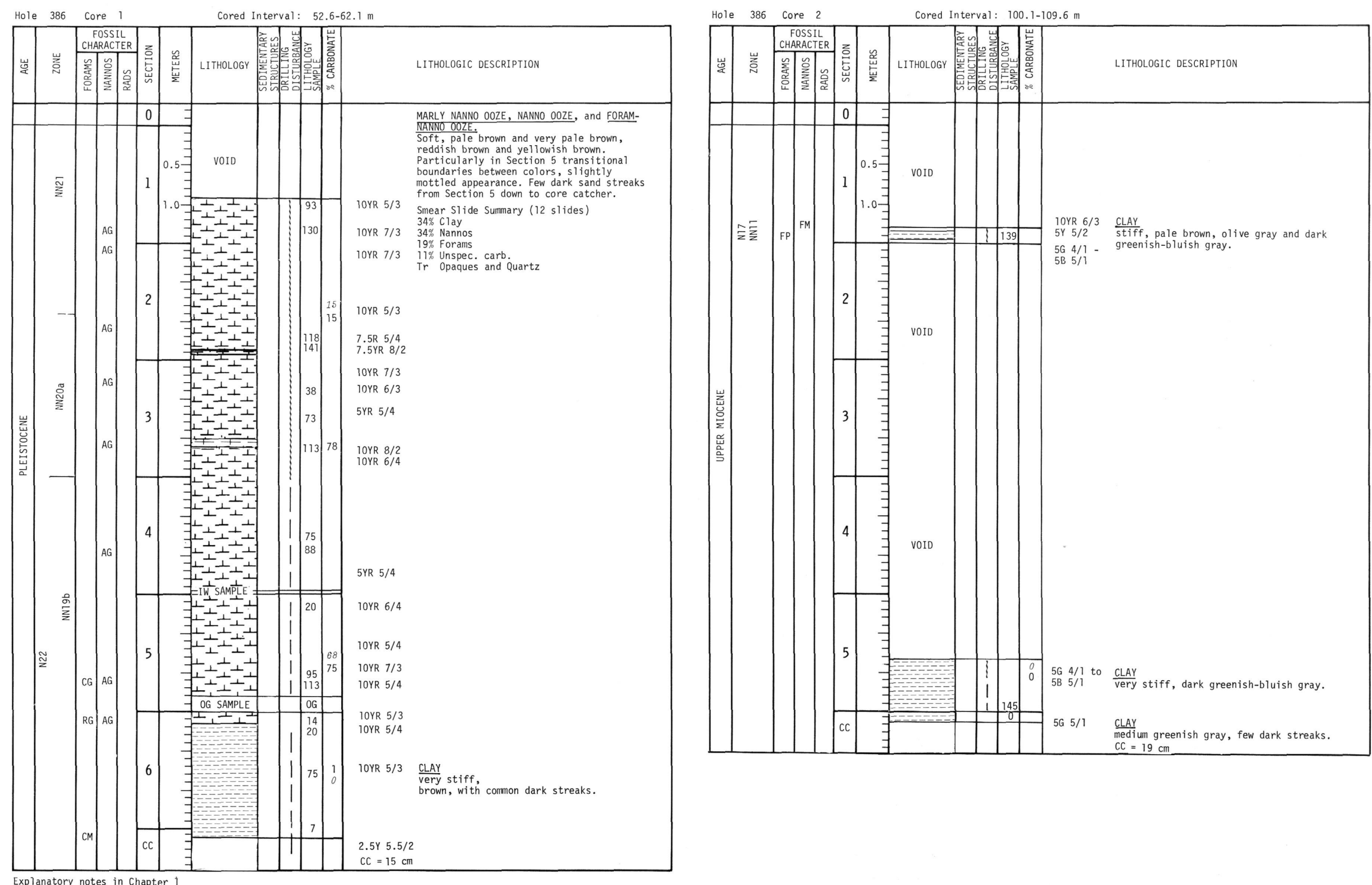


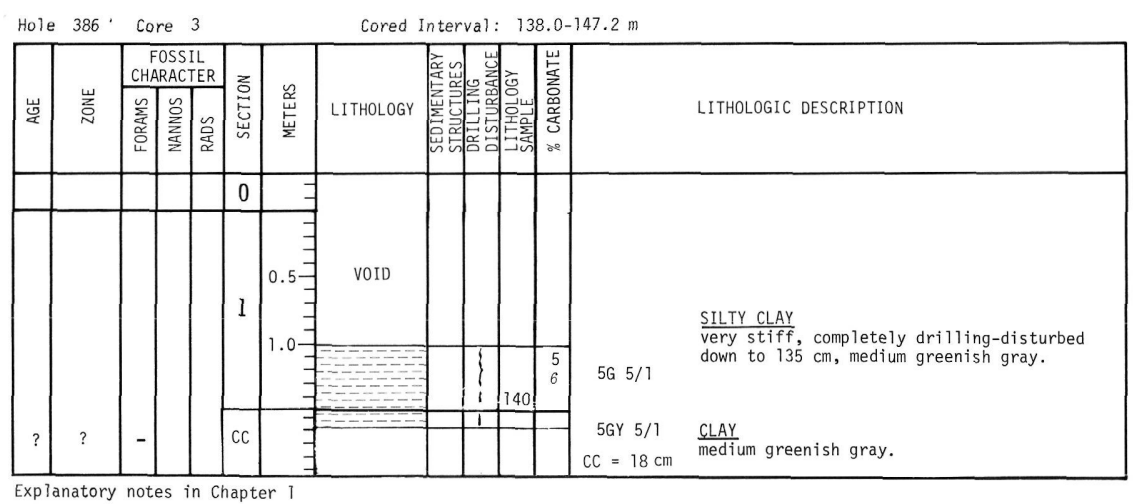

Exp?anatory notes in Chapter I

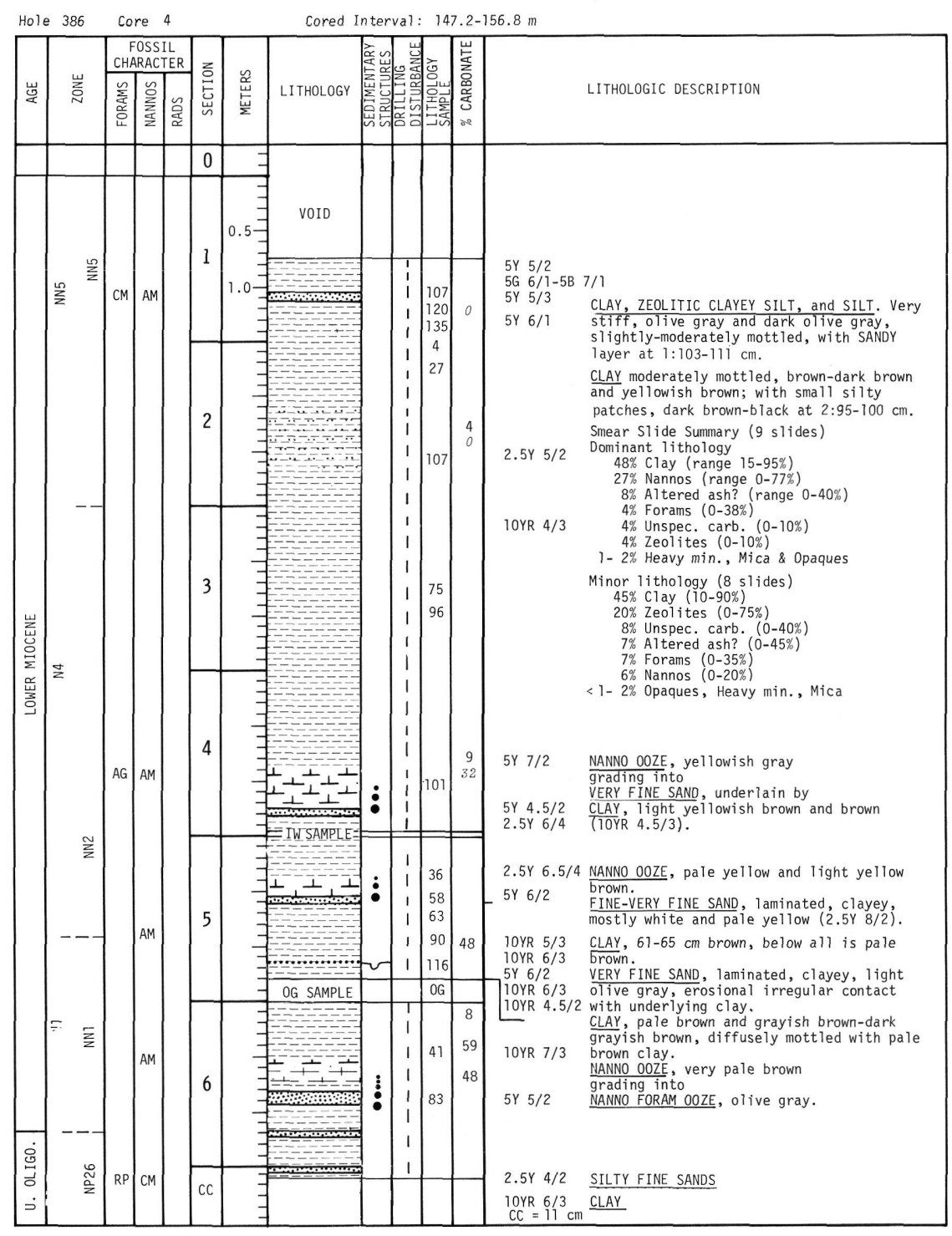



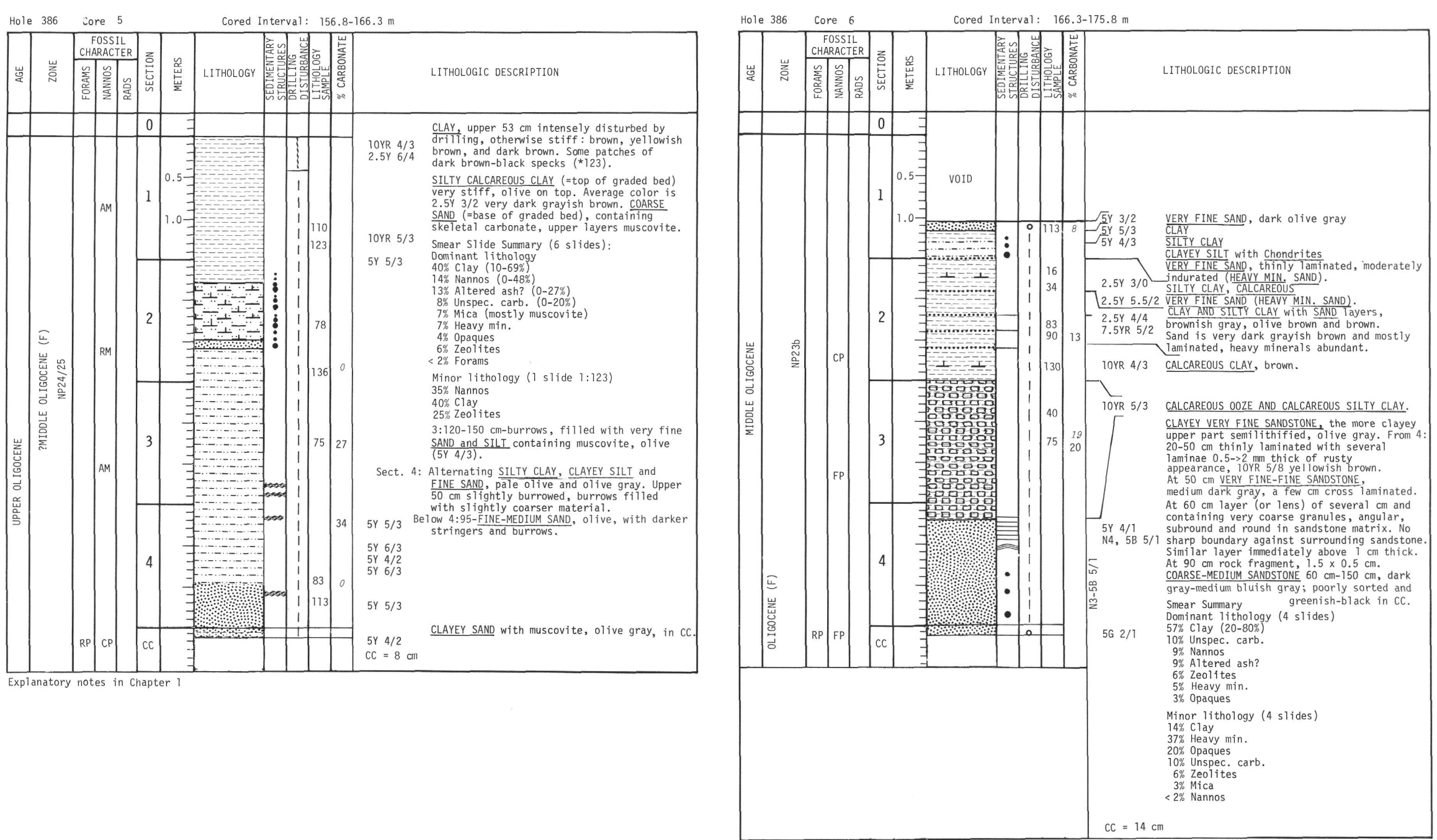

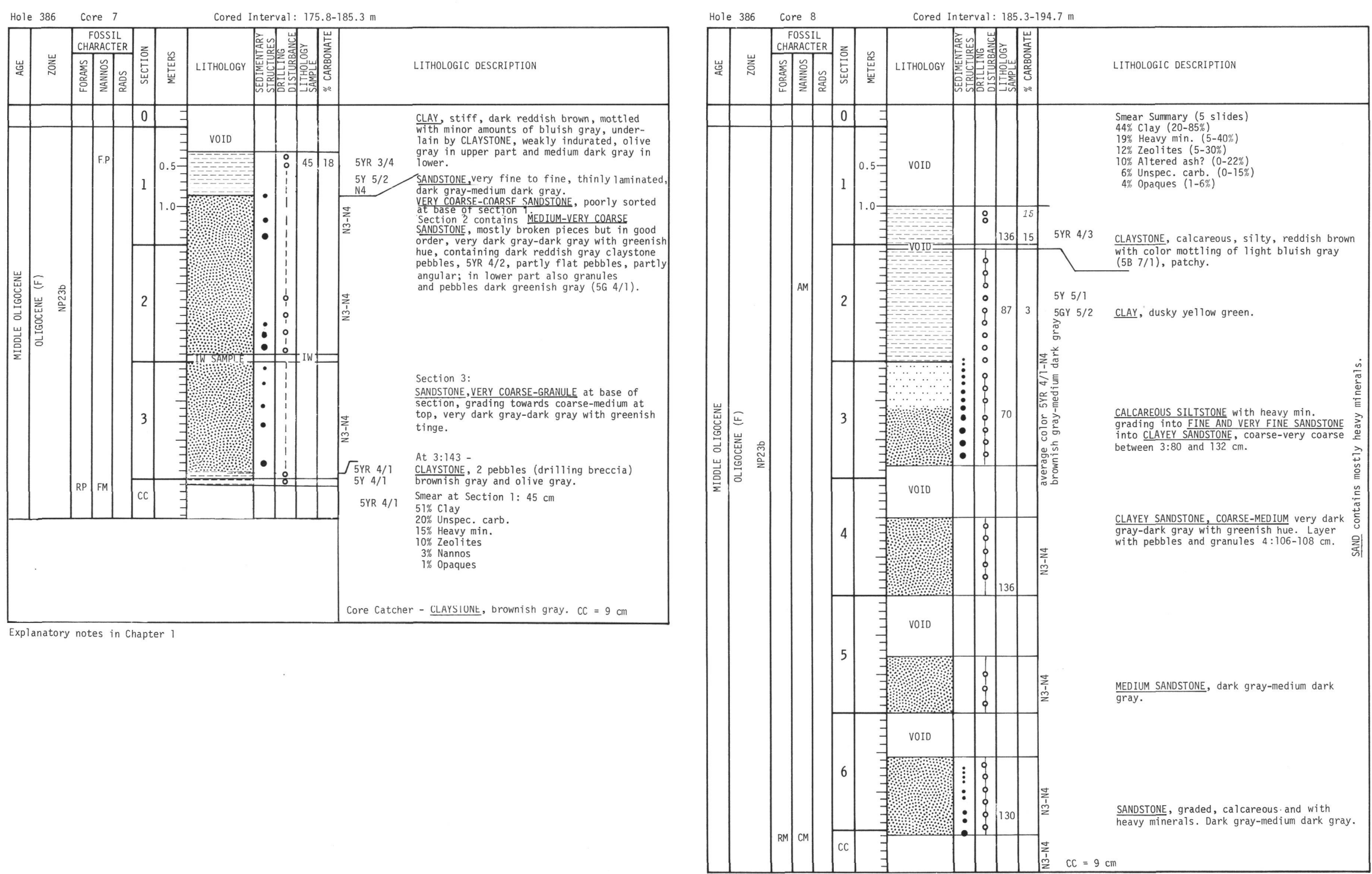


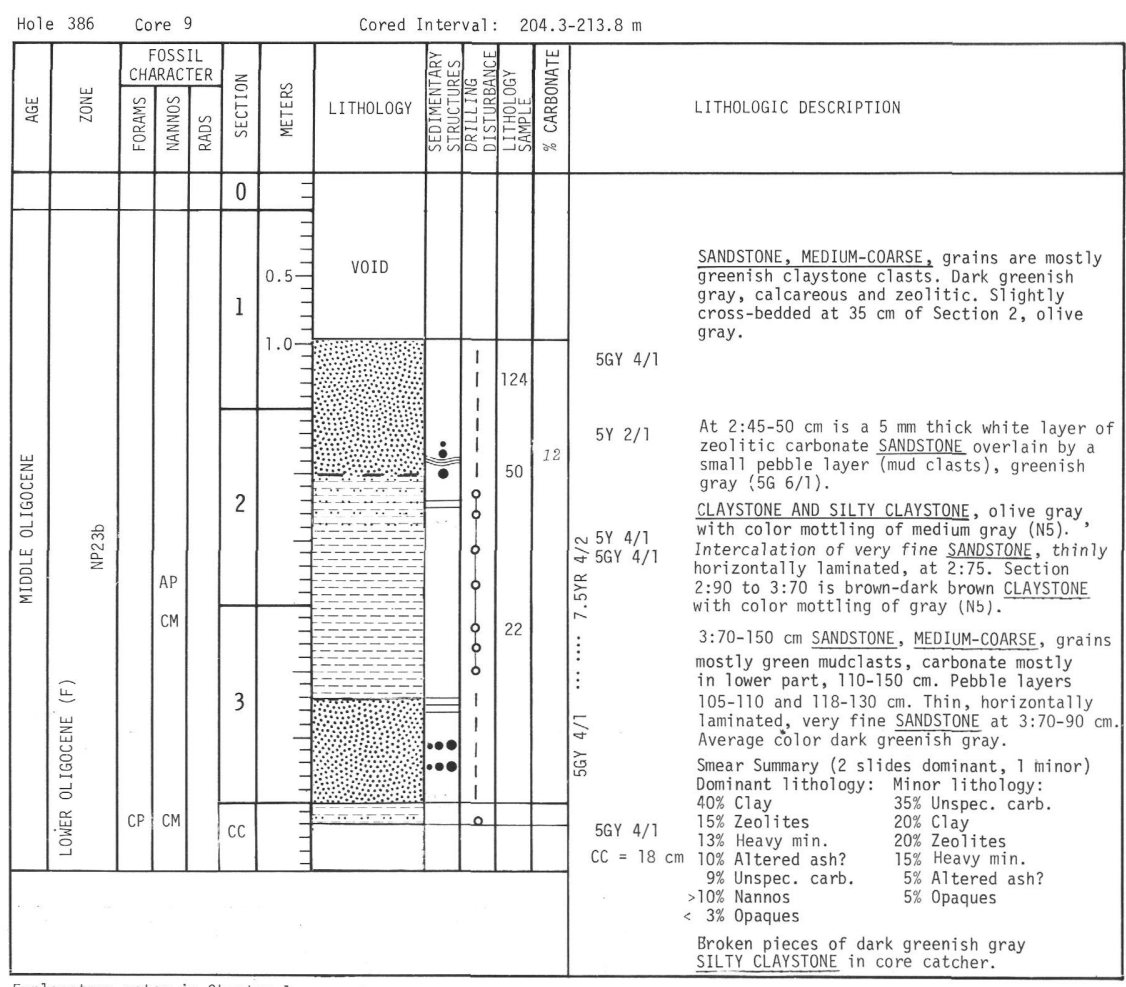

\begin{tabular}{|c|c|c|c|c|c|c|c|c|}
\hline \multicolumn{2}{|c|}{ Hole 386} & \multicolumn{2}{|c|}{ Core 10} & & \multicolumn{3}{|c|}{ Cored Interval: $223.3-232.9 \mathrm{~m}$} & \multirow[b]{2}{*}{ LITHOLOGIC DESCRIPTION } \\
\hline 岩 & 言 & 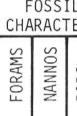 & 㑅施 & 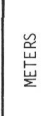 & LITHOLOGY & 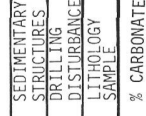 & & \\
\hline & & & 0 & 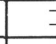 & & 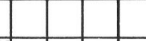 & \multirow{3}{*}{\multicolumn{2}{|c|}{ 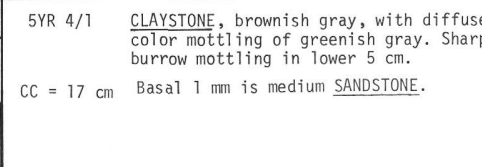 }} \\
\hline $\mid$ & & 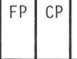 & cc & & & onos & & \\
\hline $\begin{array}{l}\vec{b} \\
\dot{\Sigma}\end{array}$ & $\frac{\tilde{z}}{z}$ & & & & & & & \\
\hline
\end{tabular}

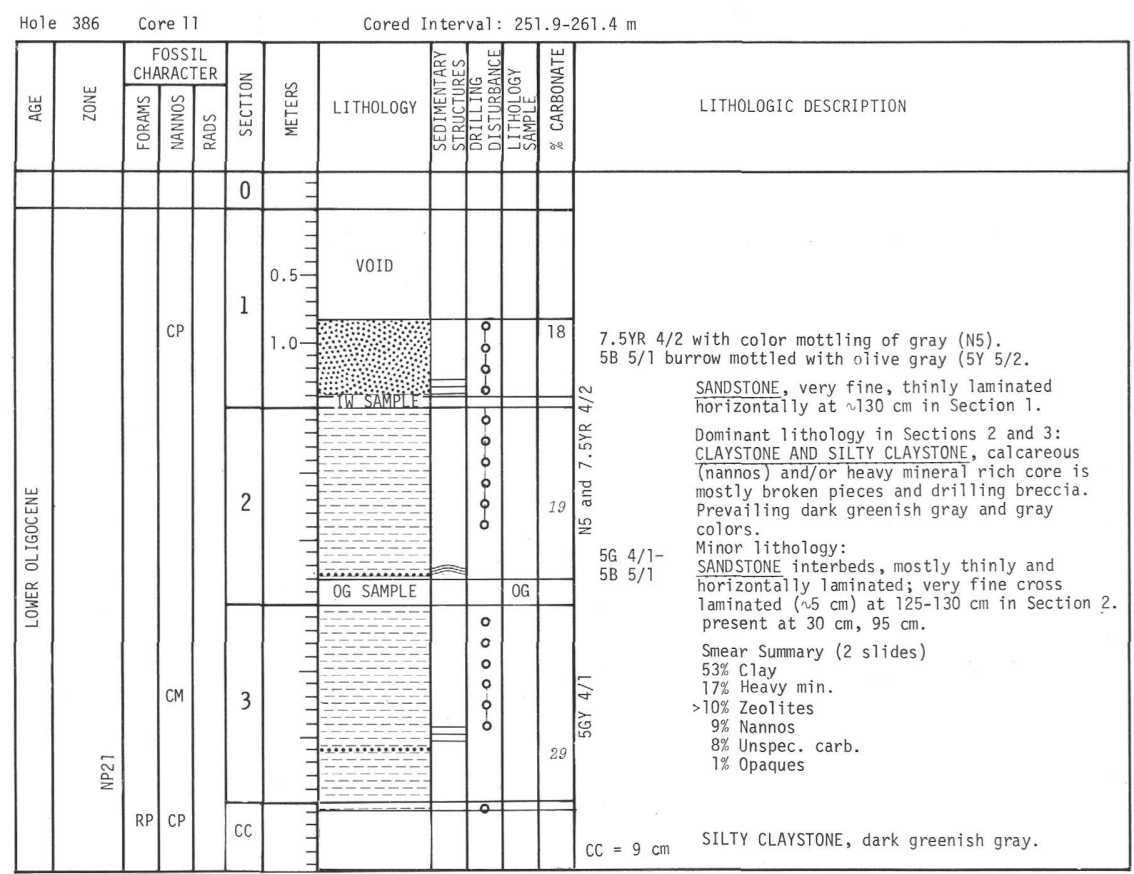




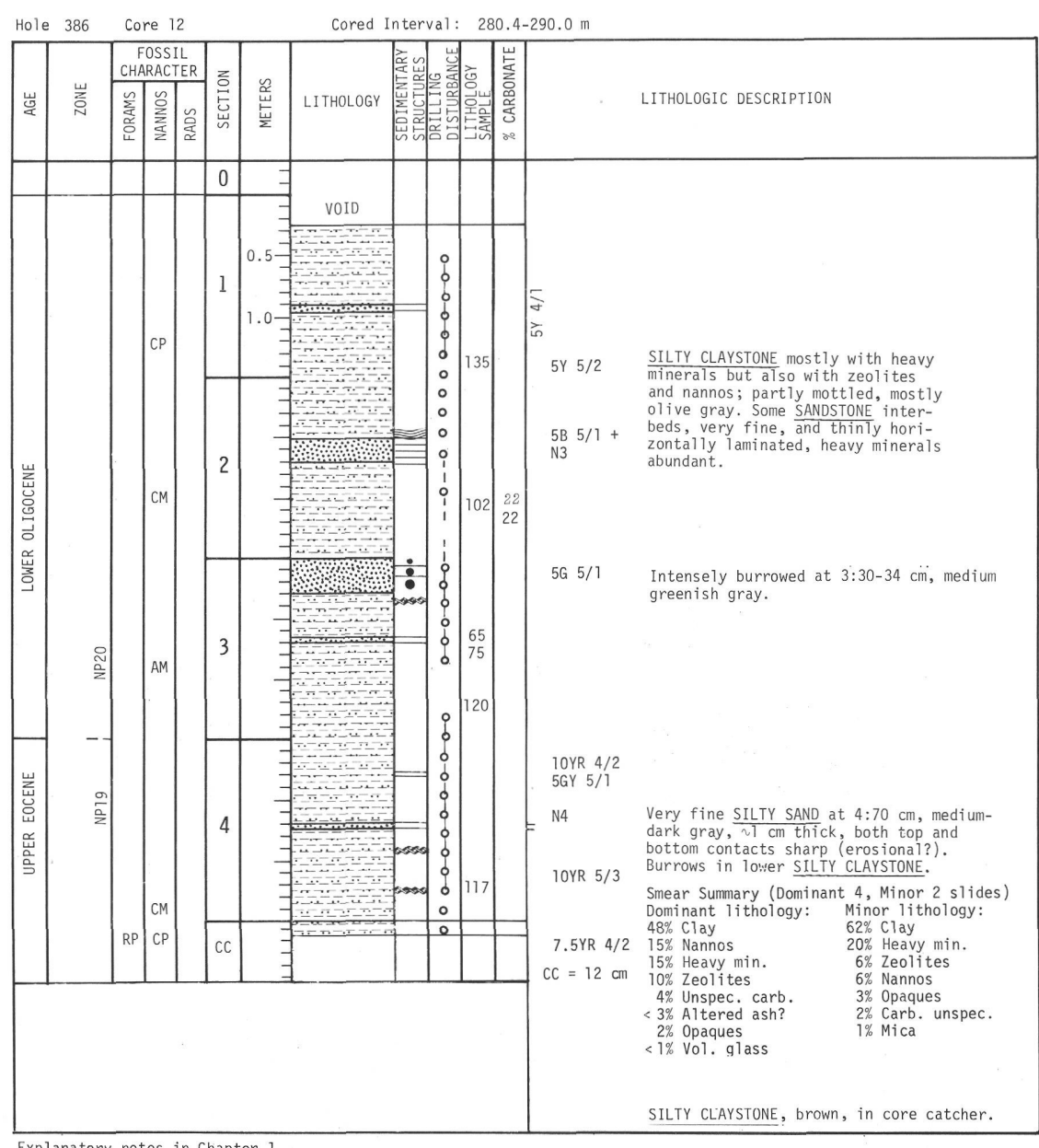

Explanatory notes in Chapter 7

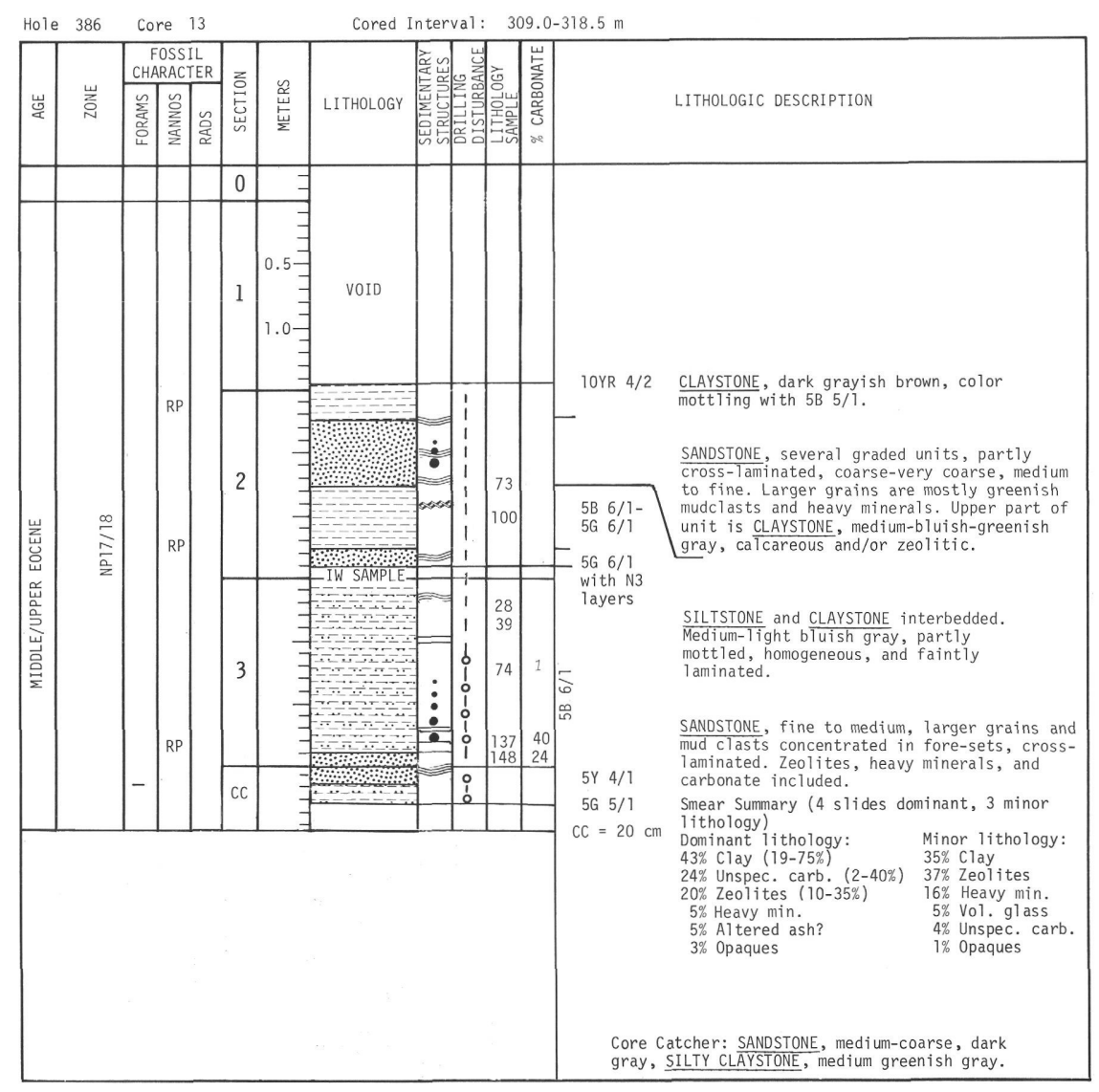

, 

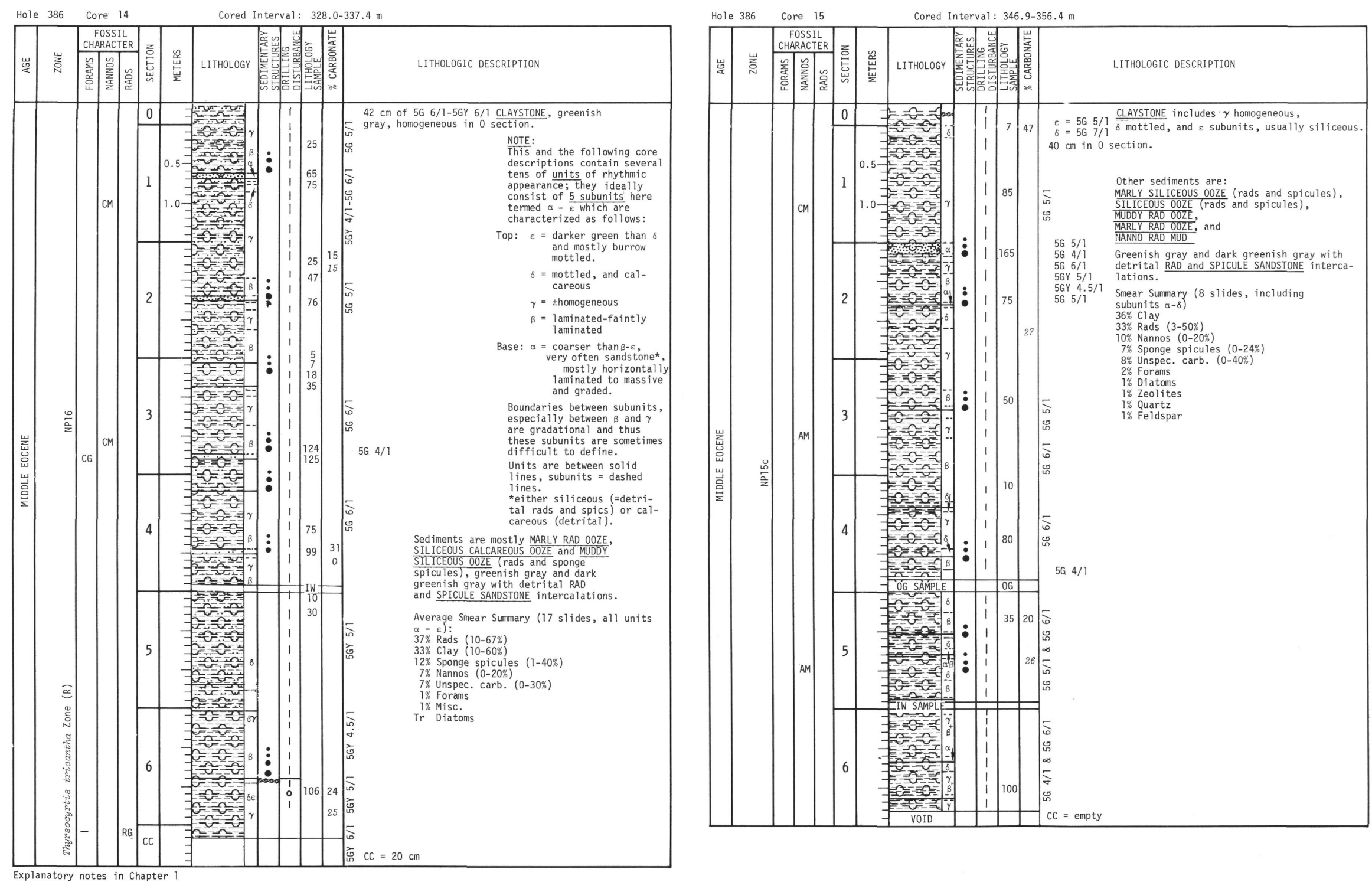


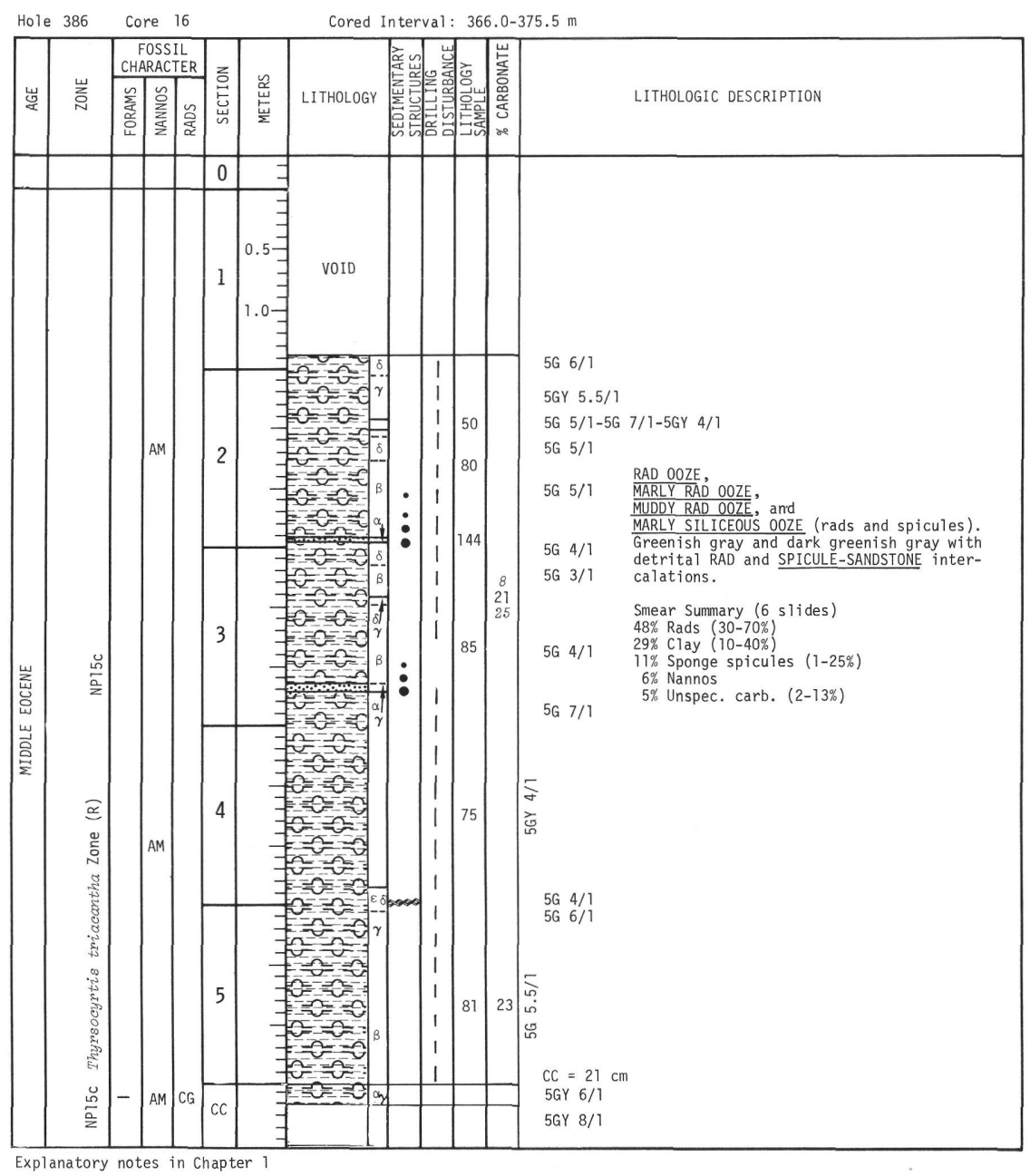

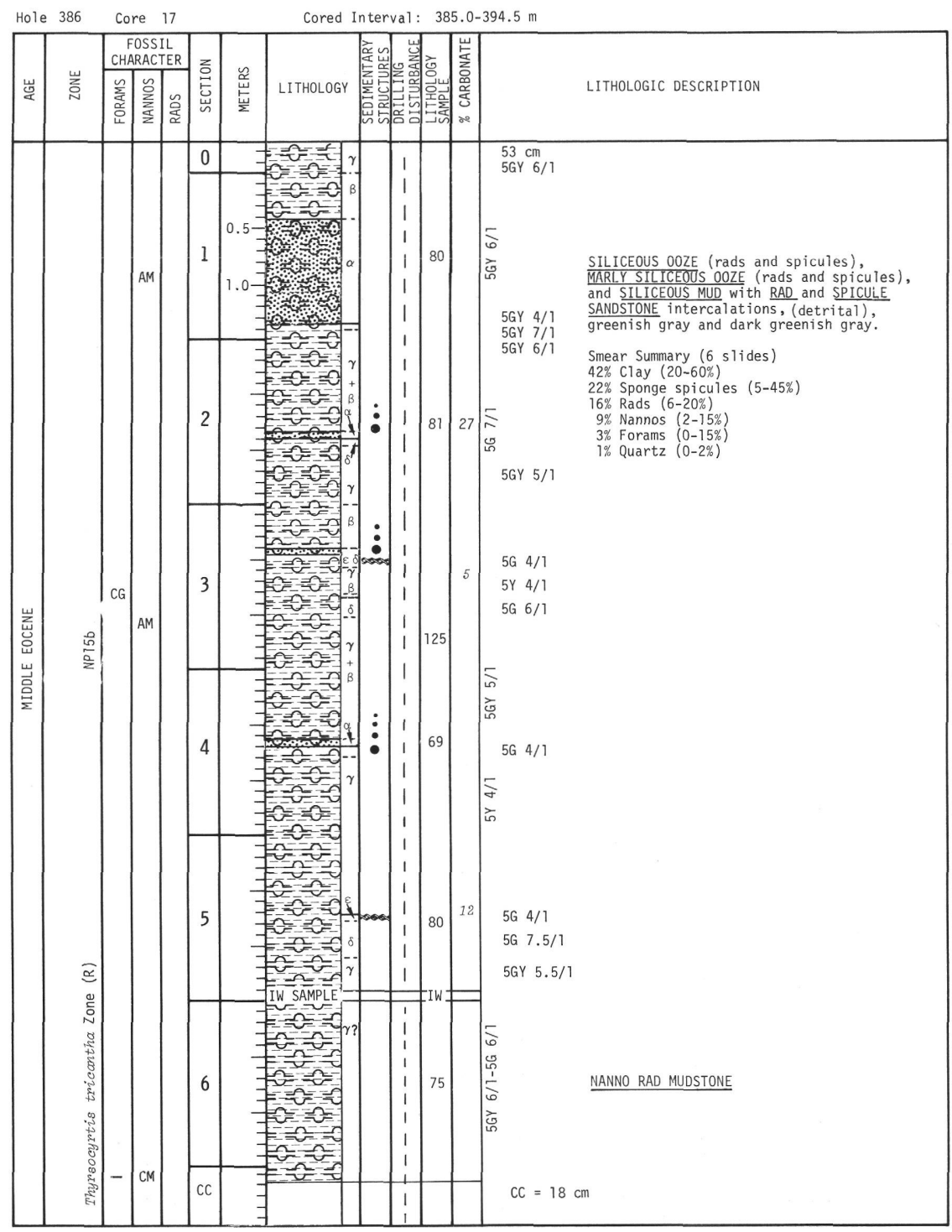



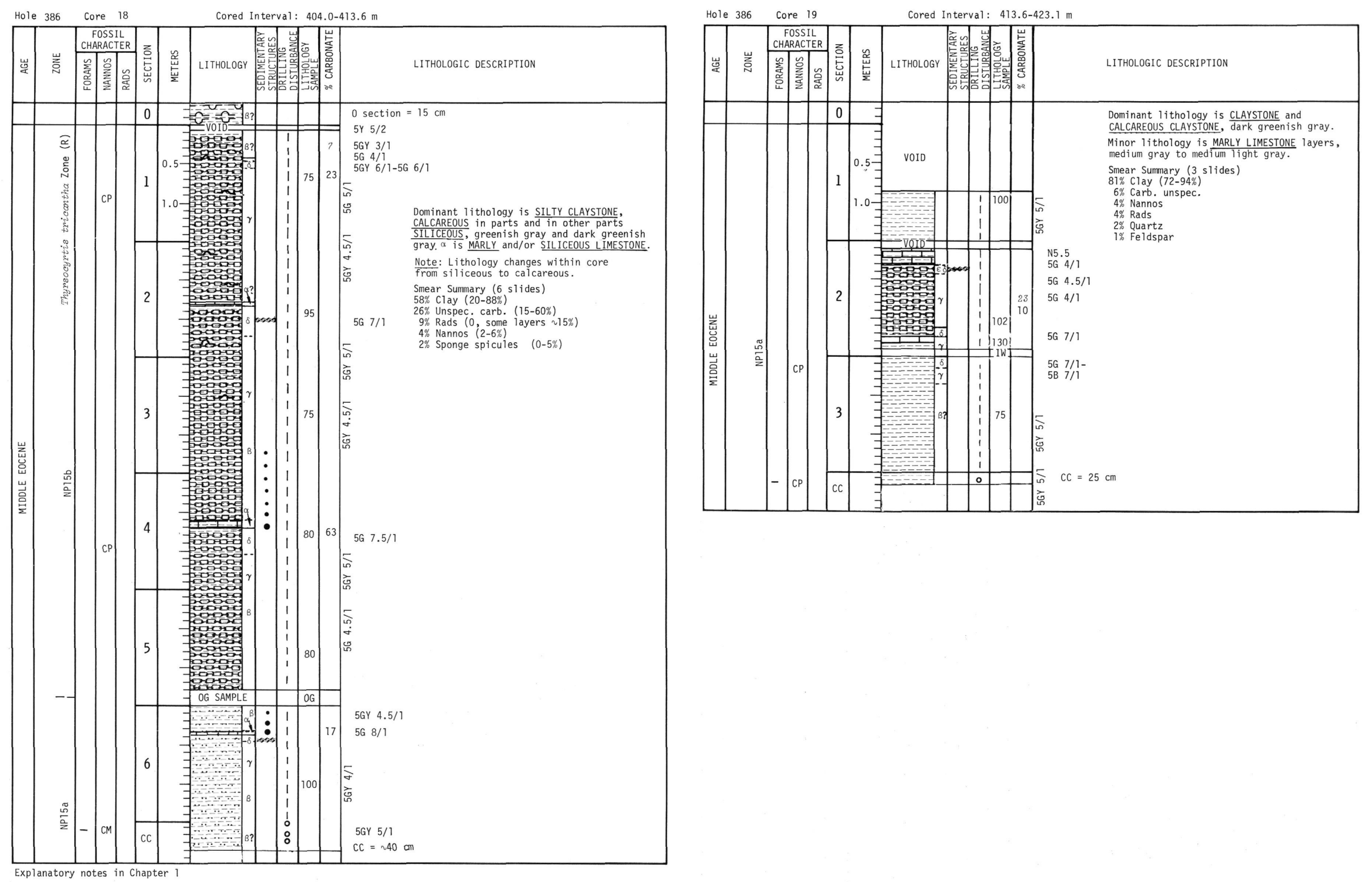

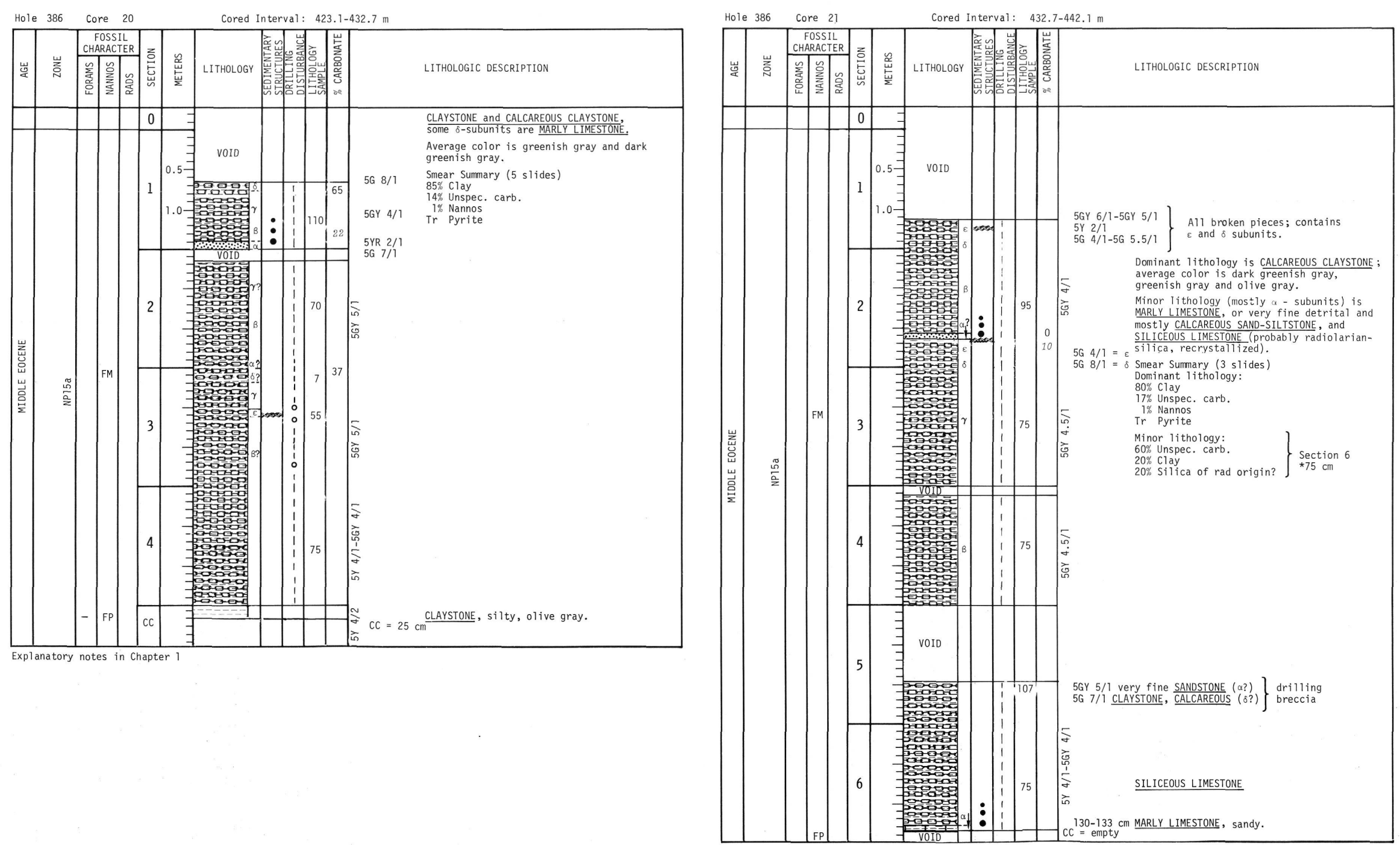

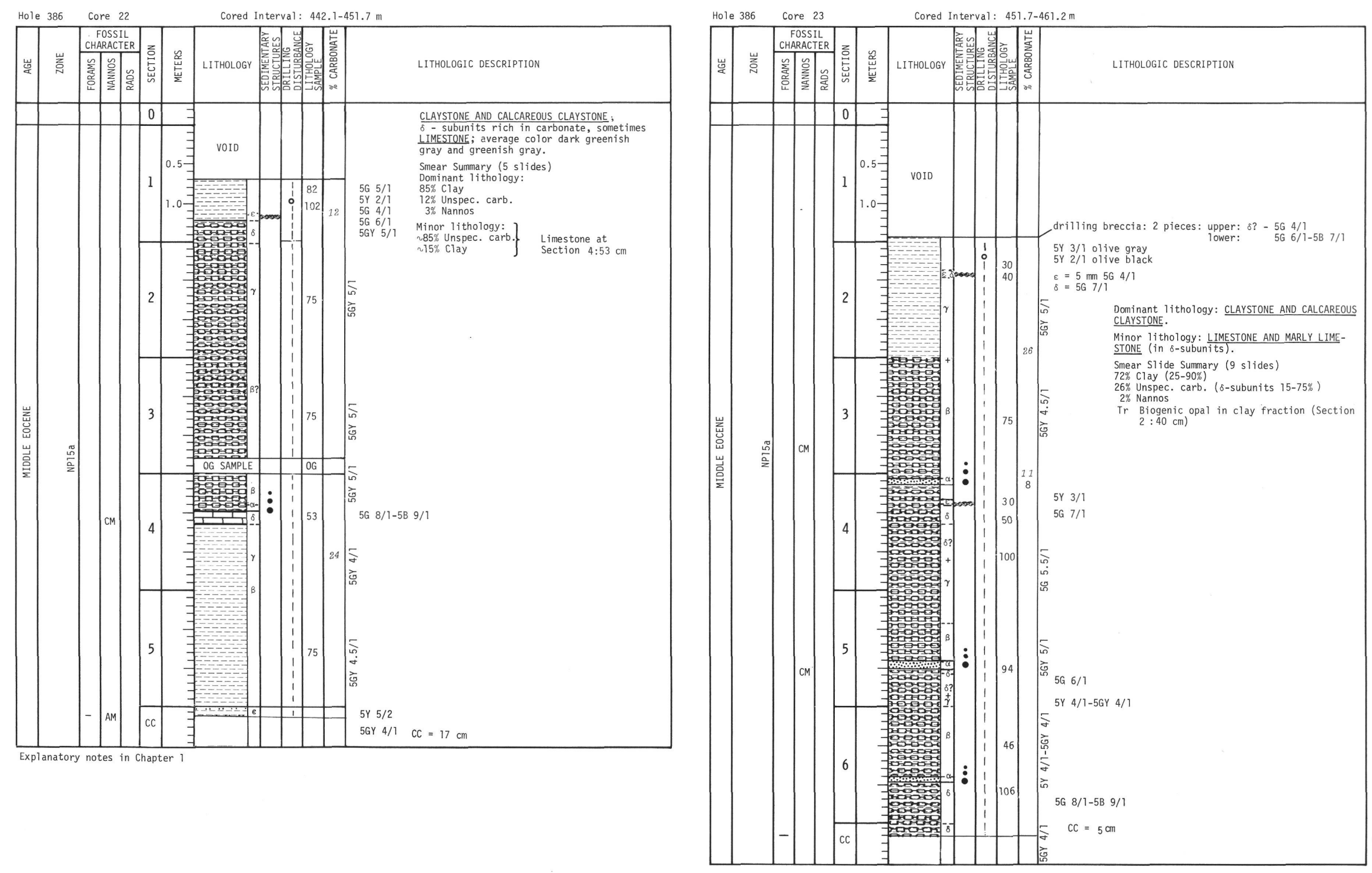


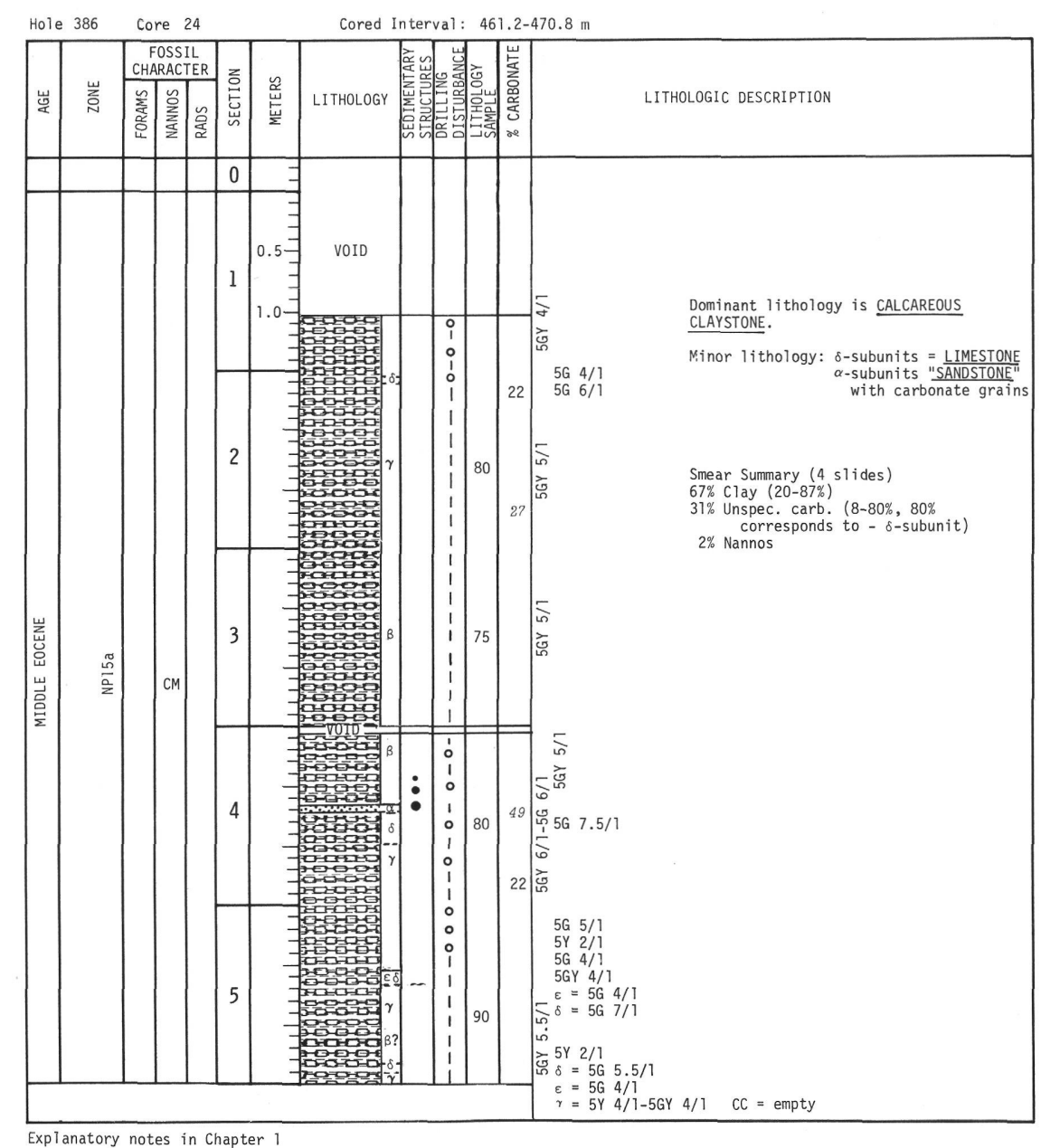

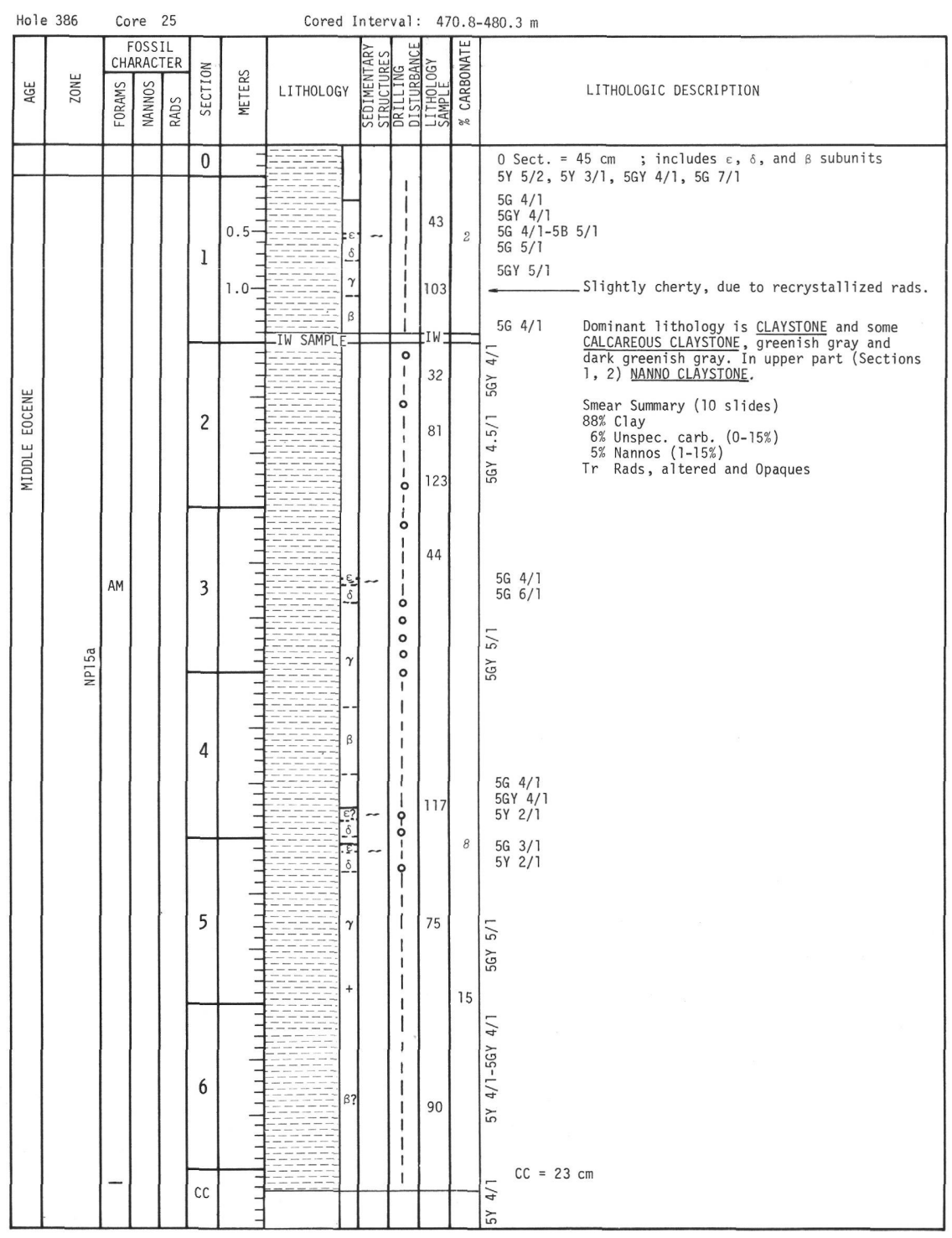



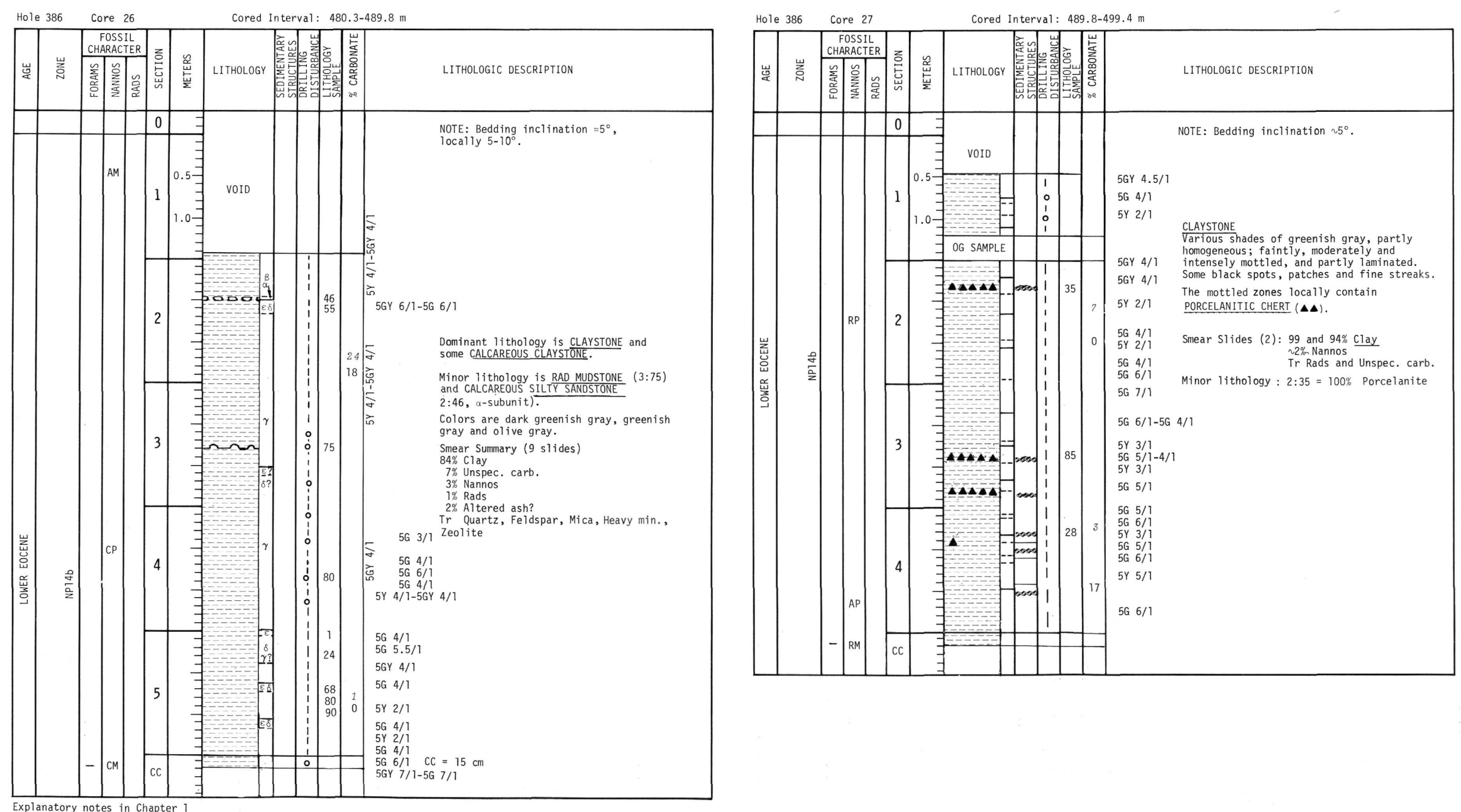


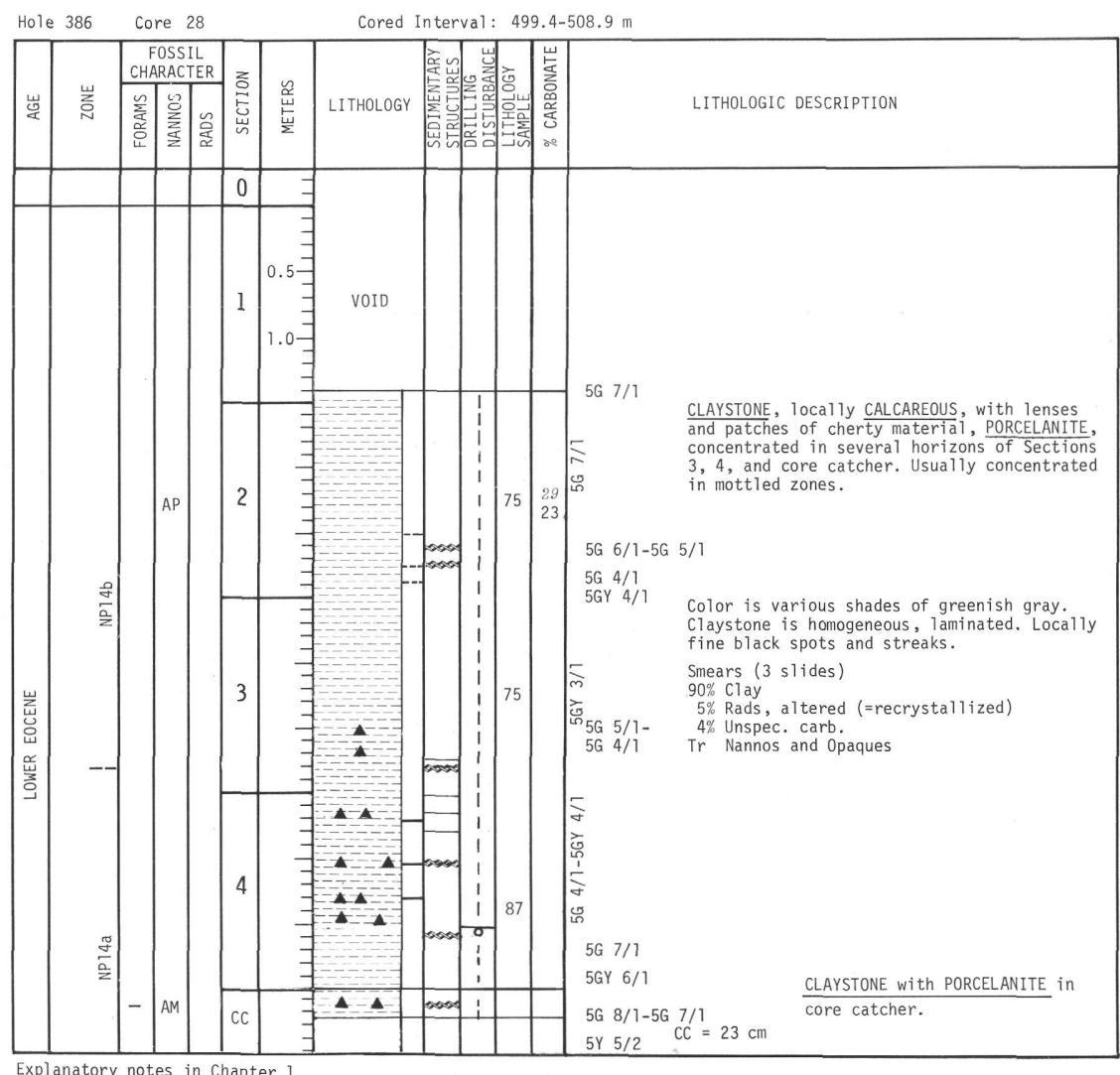

Explanatory notes in Chapter ?

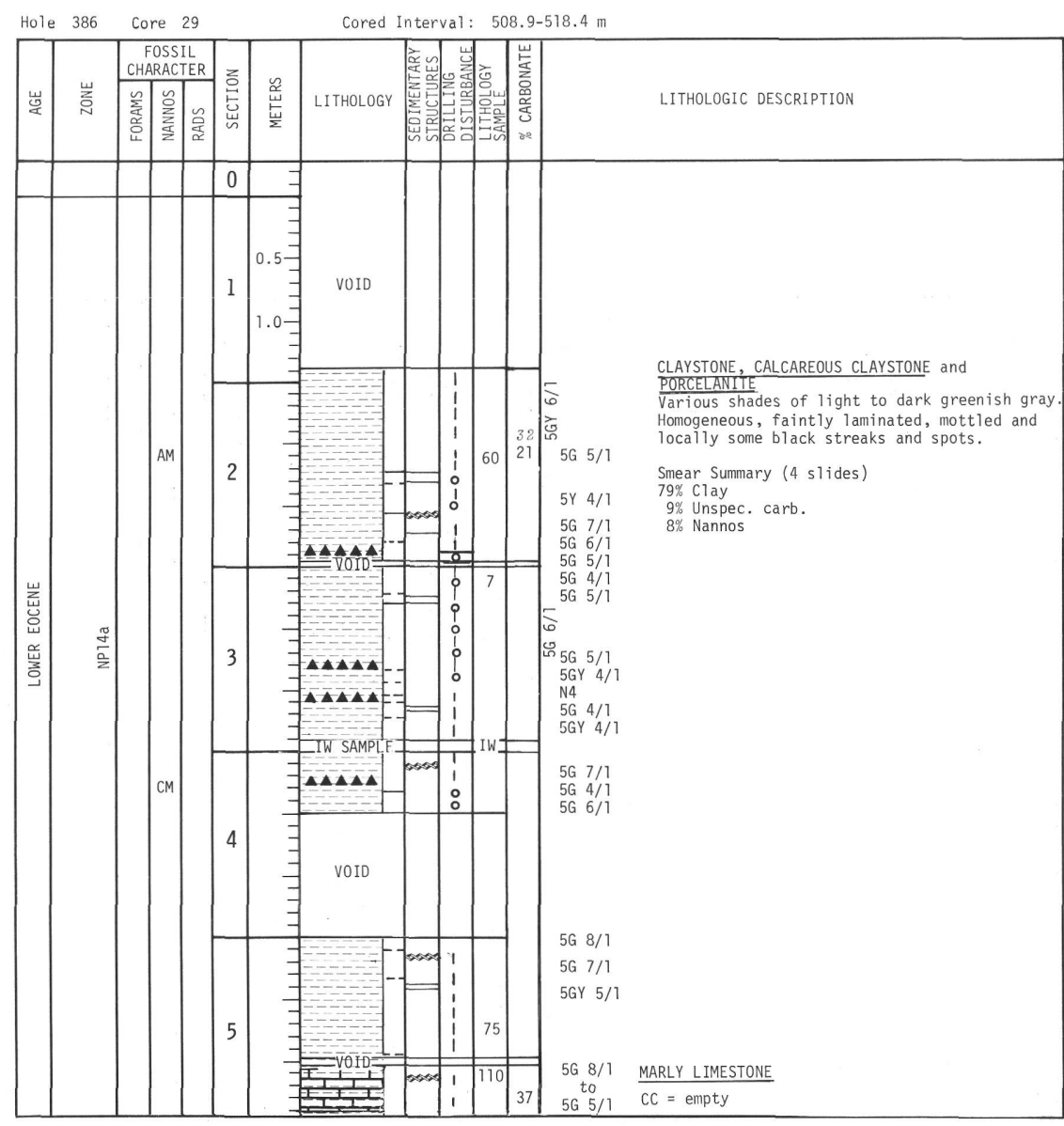



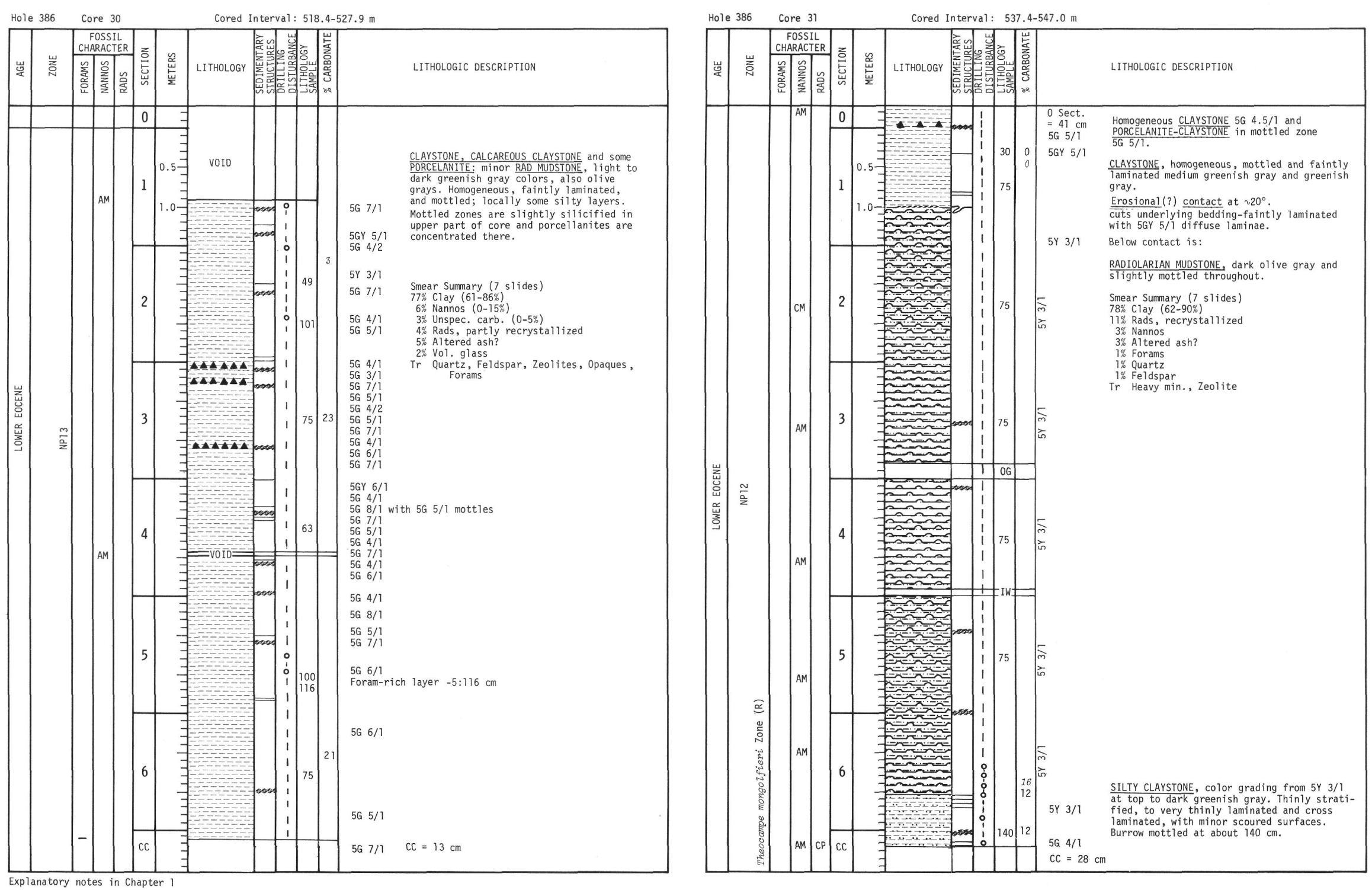

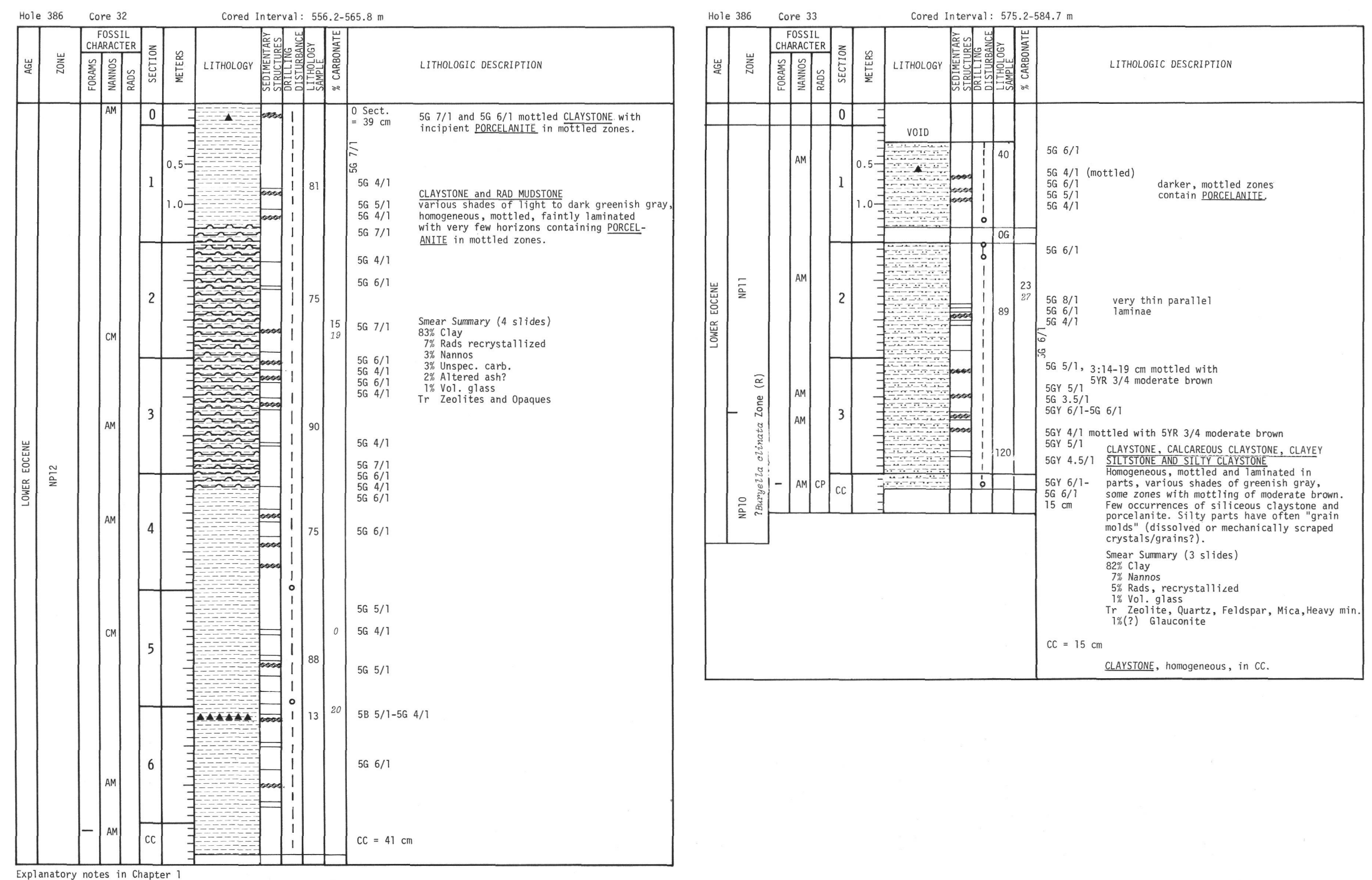


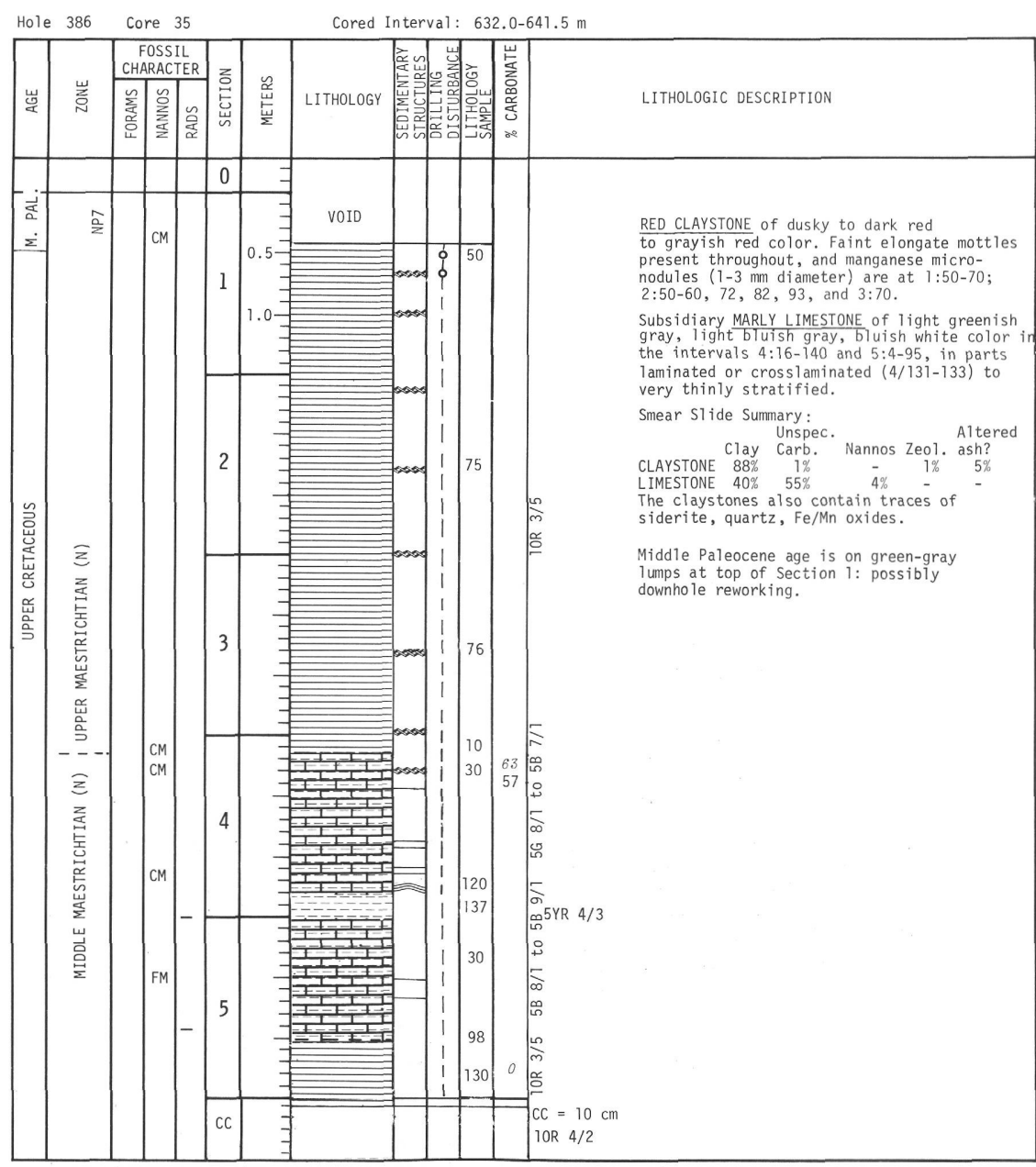



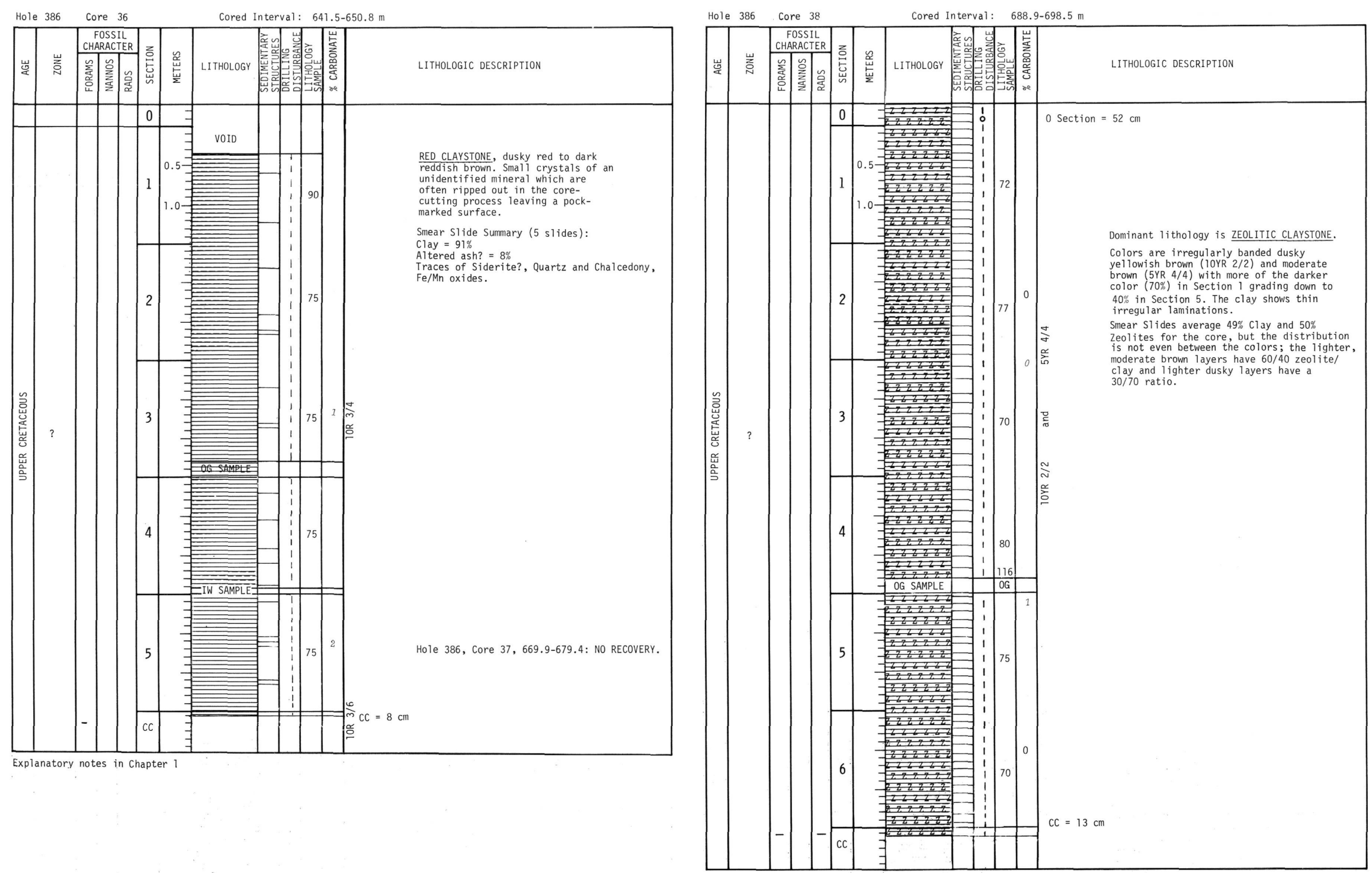


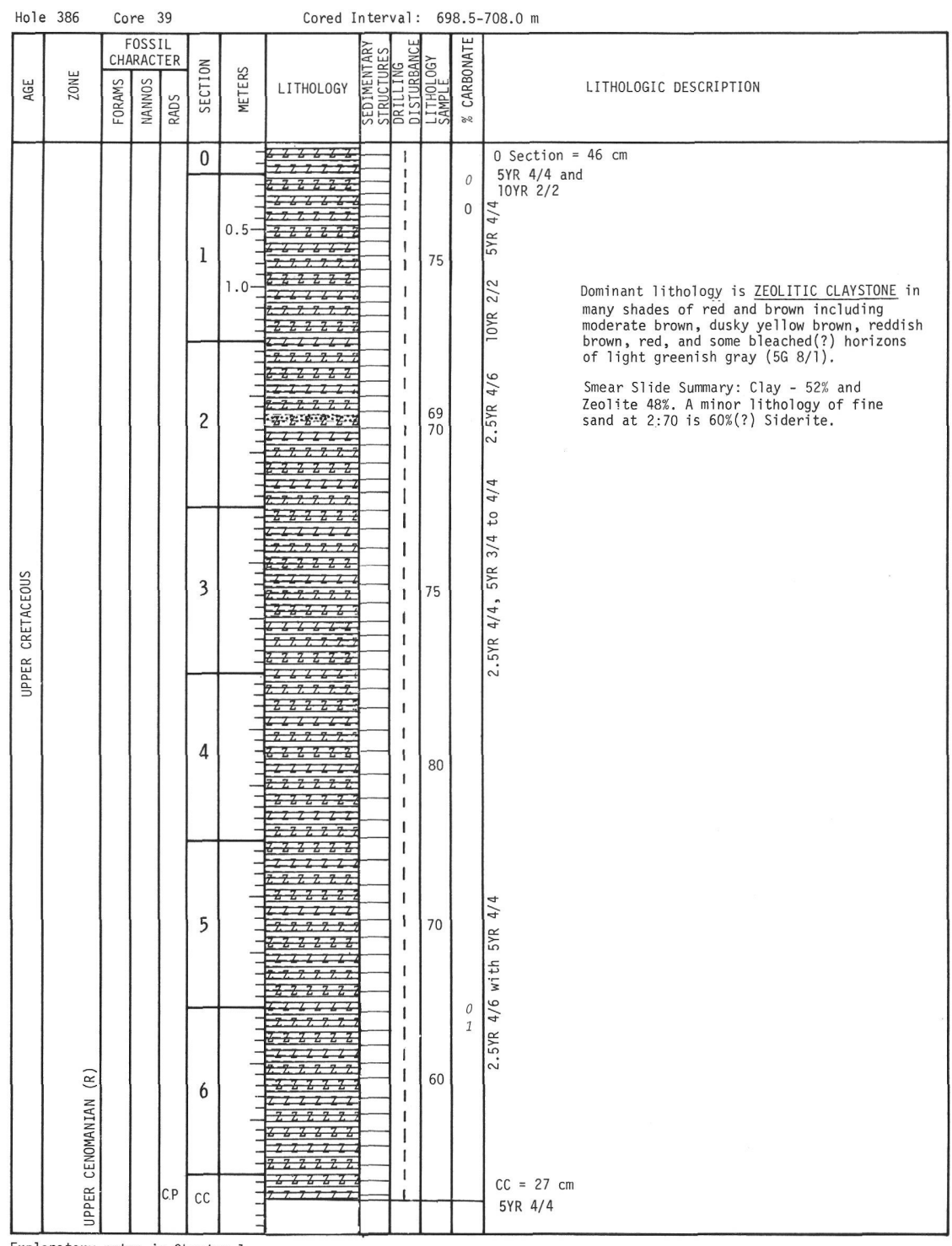

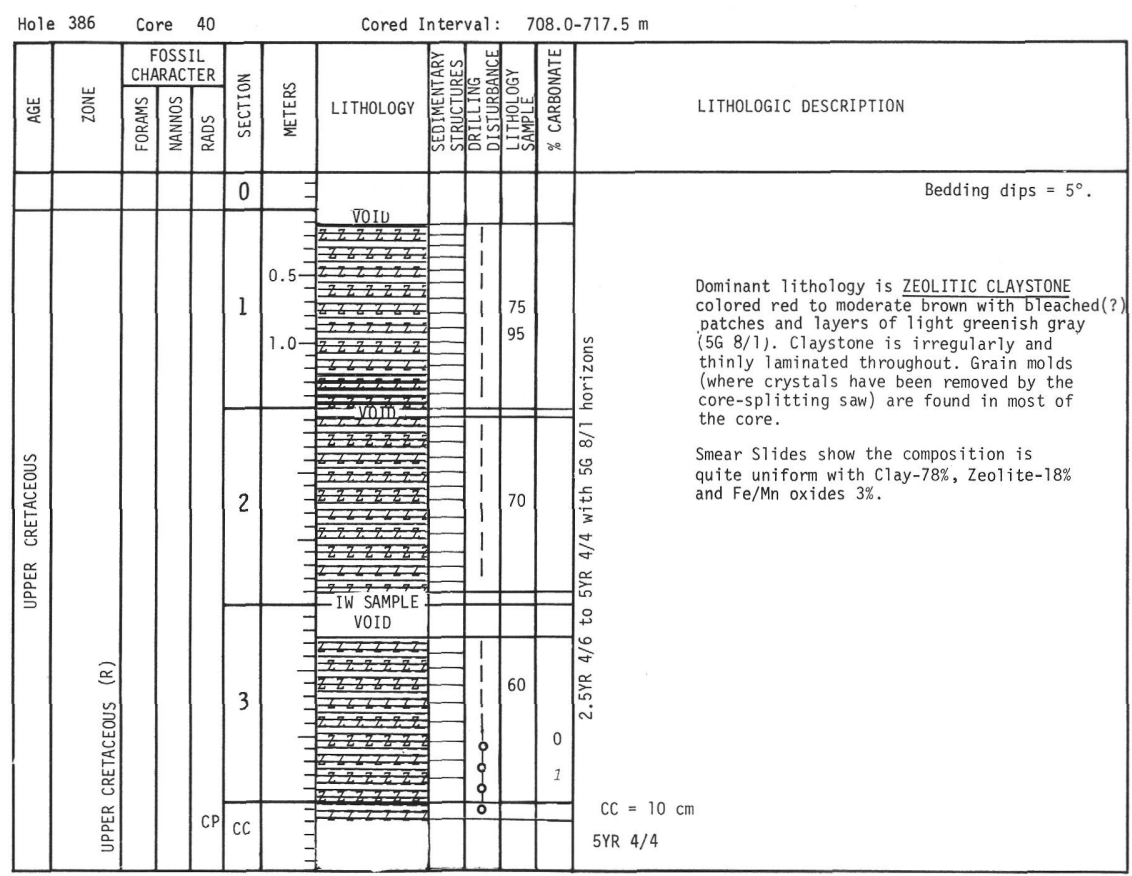



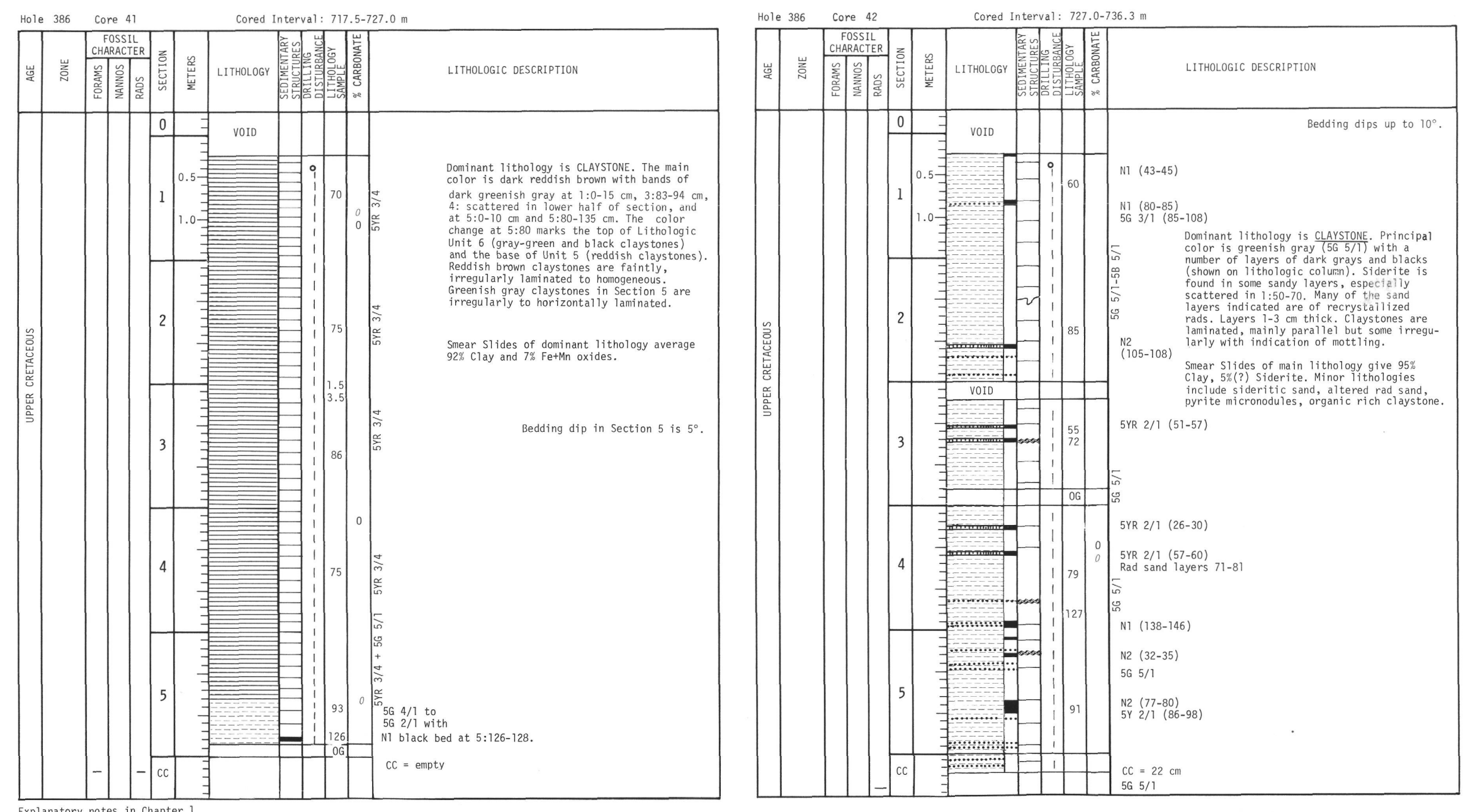

Explanatory notes in chapter 

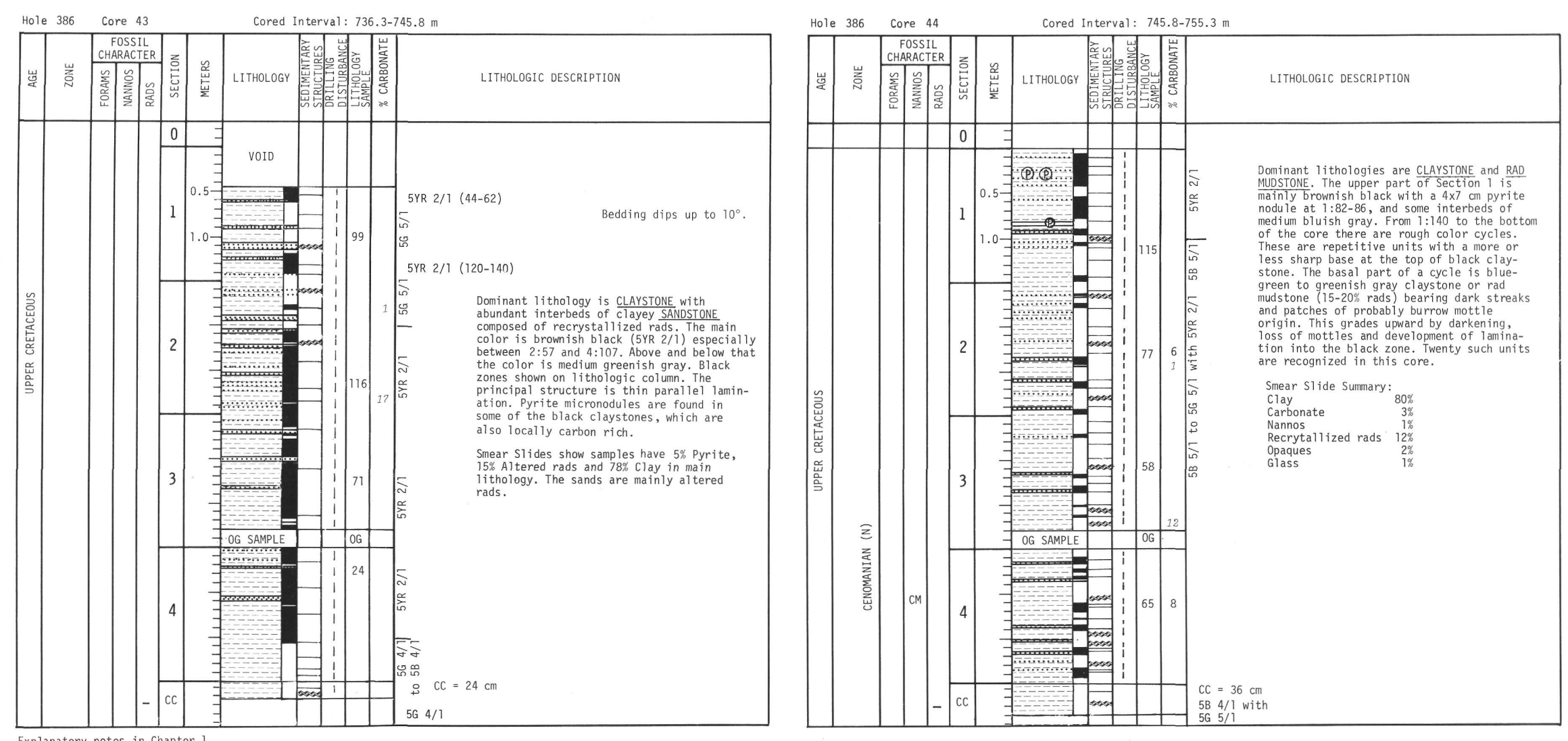

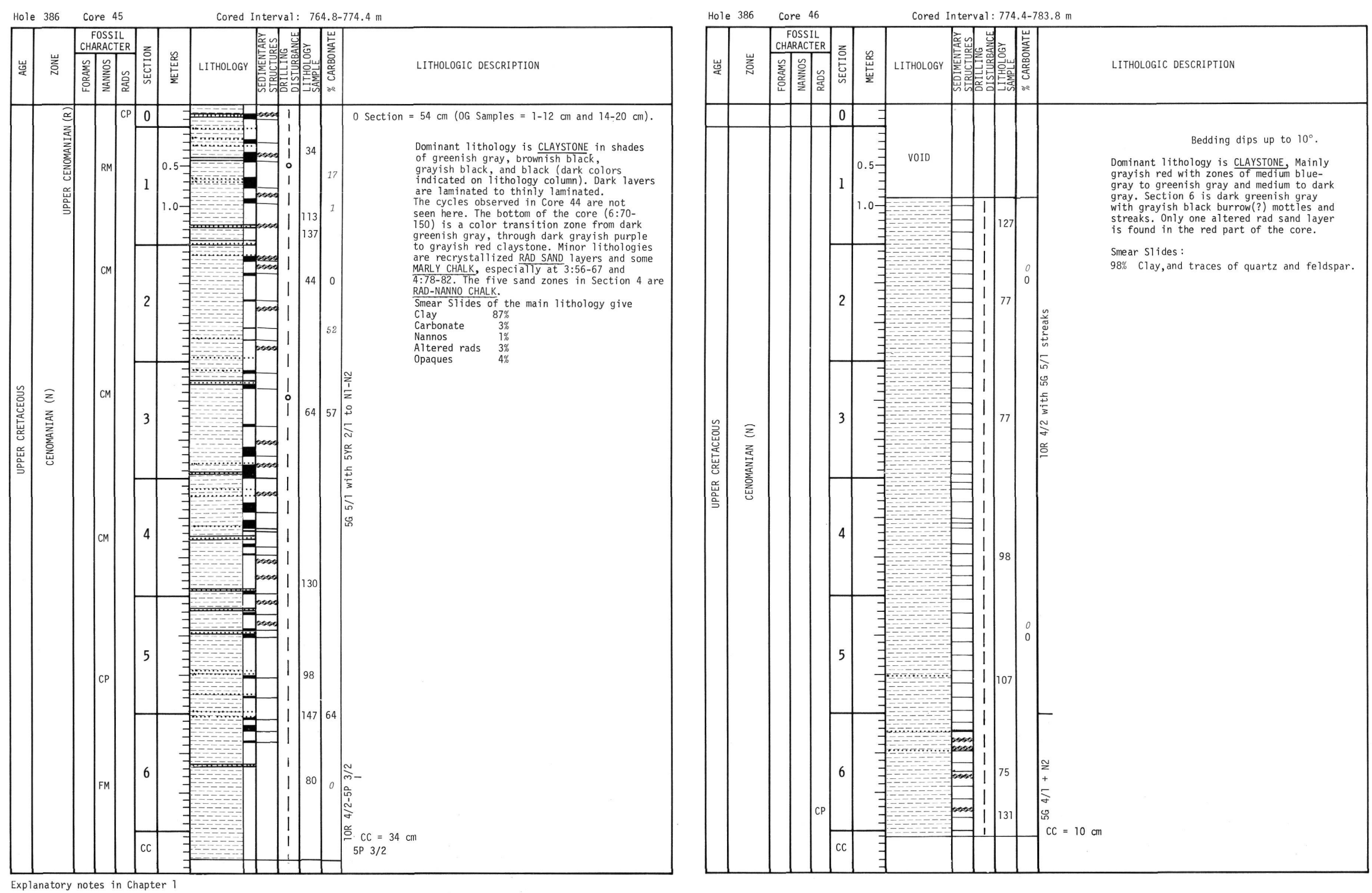

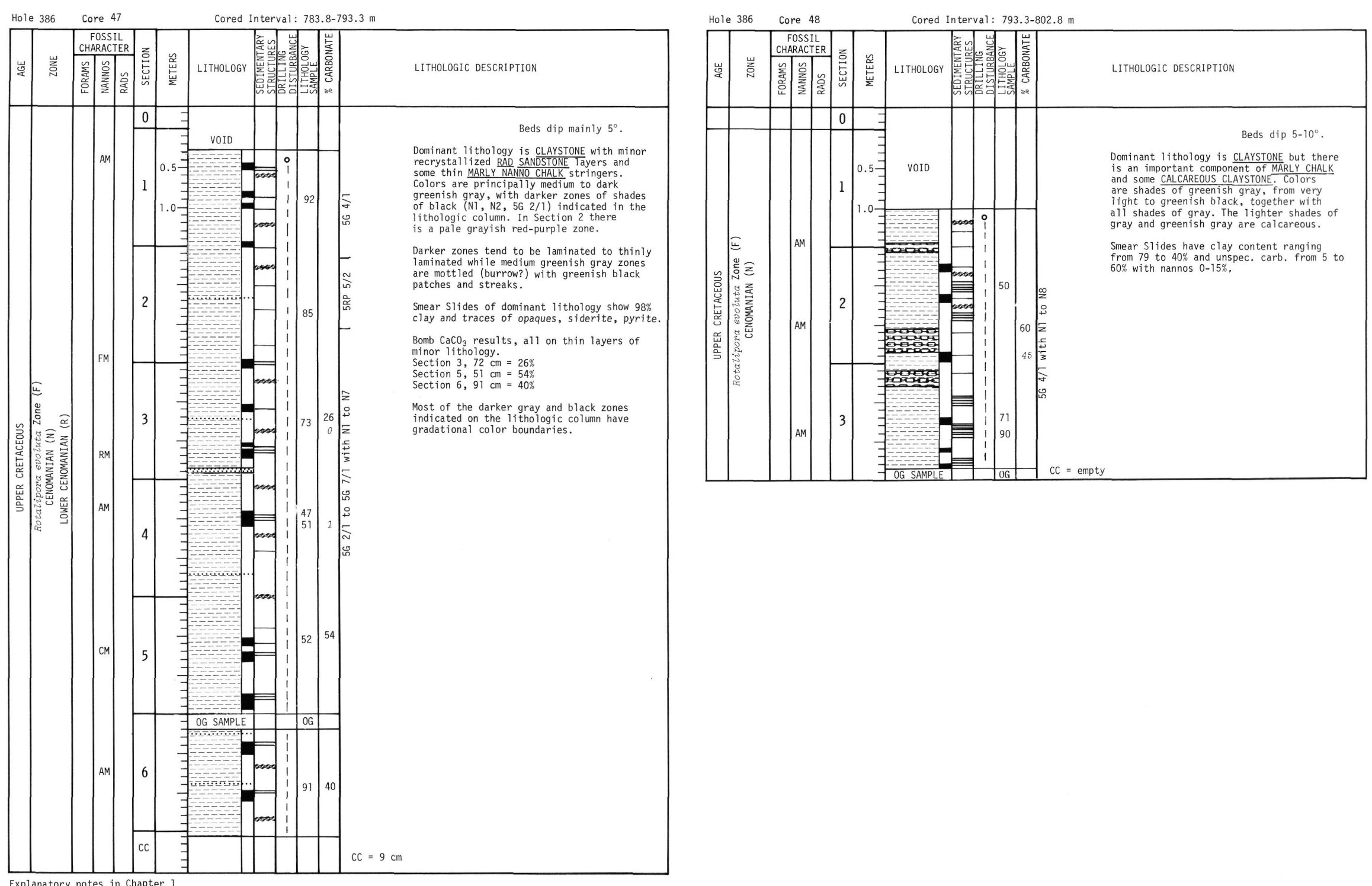

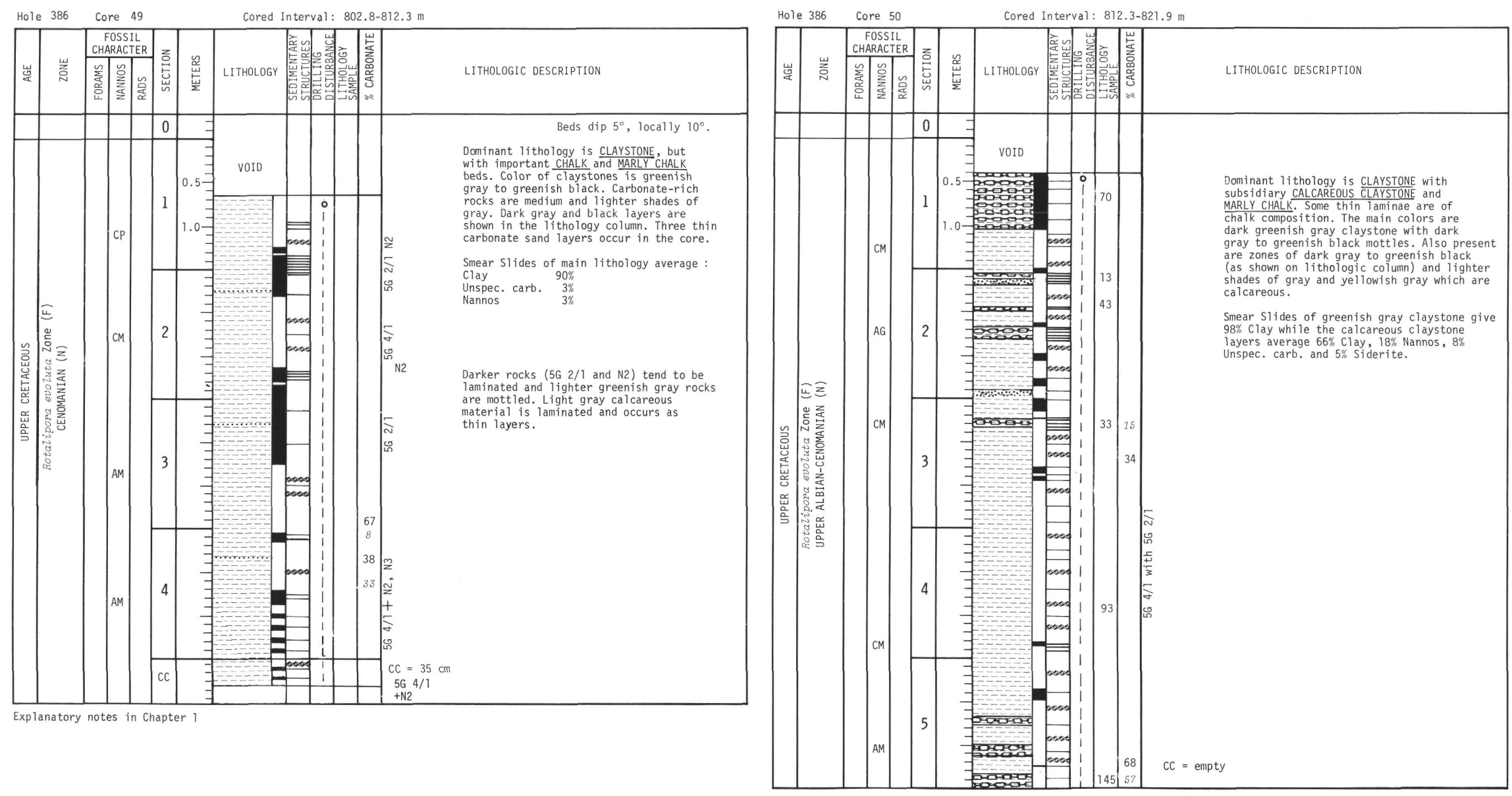

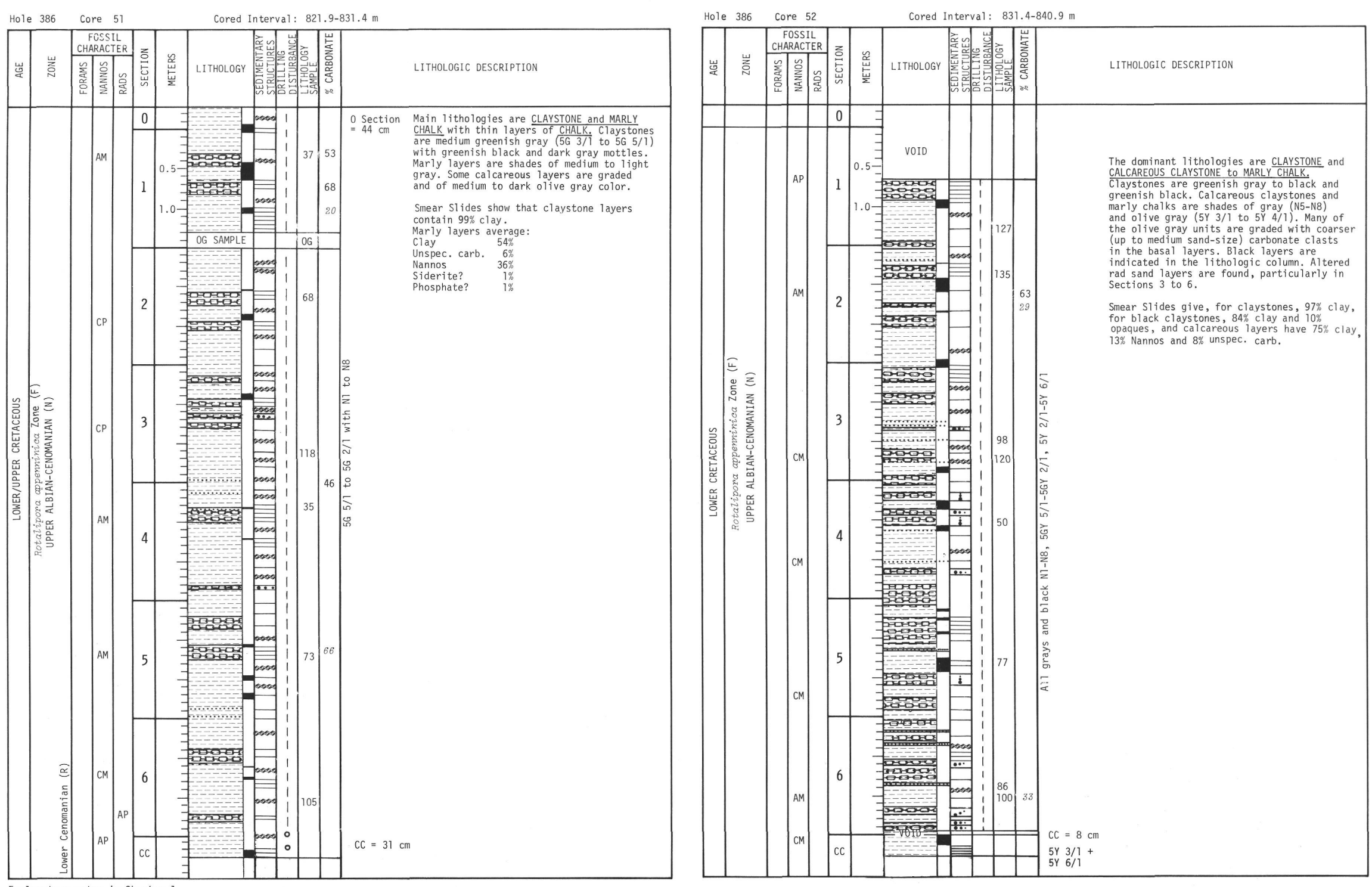

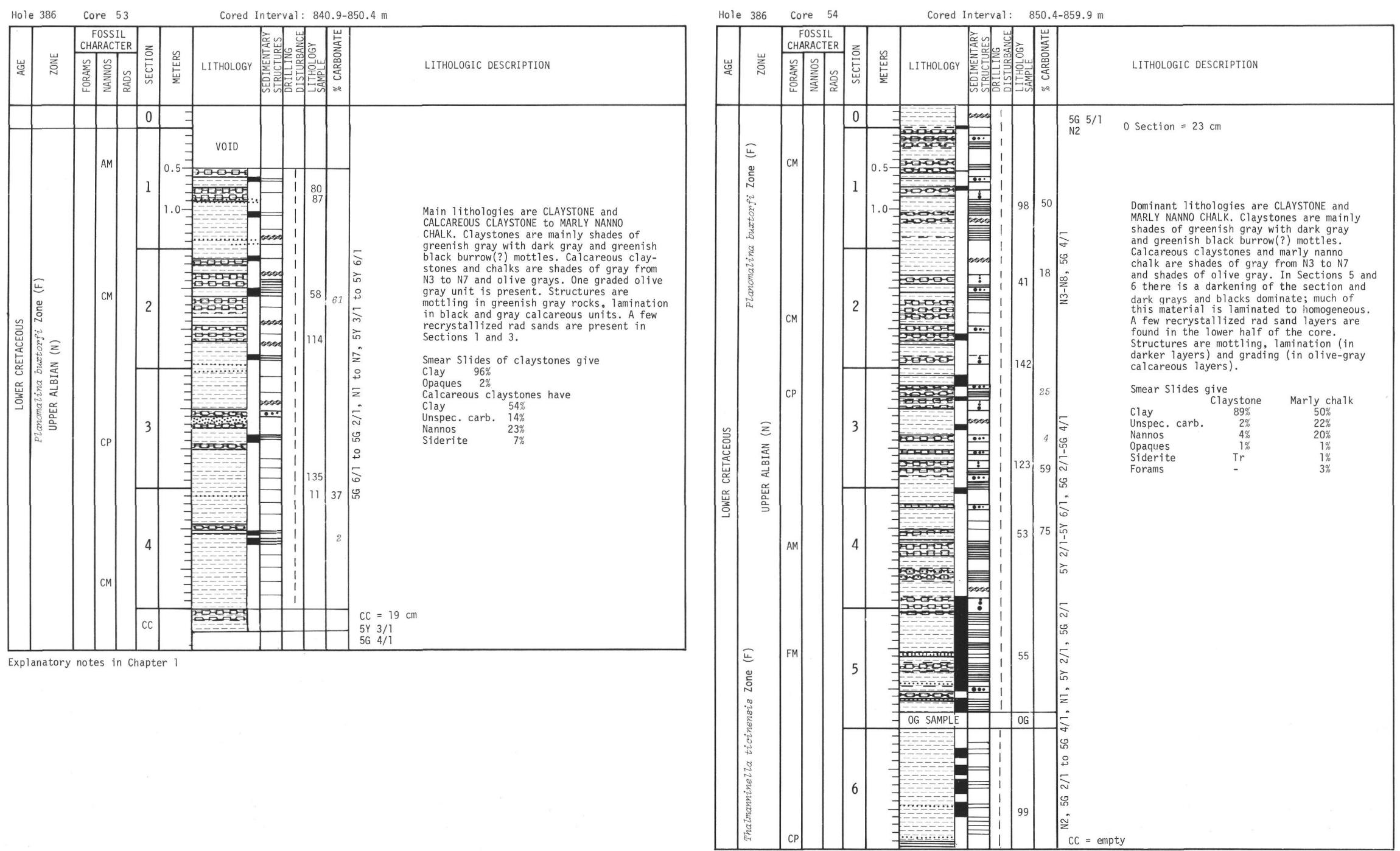

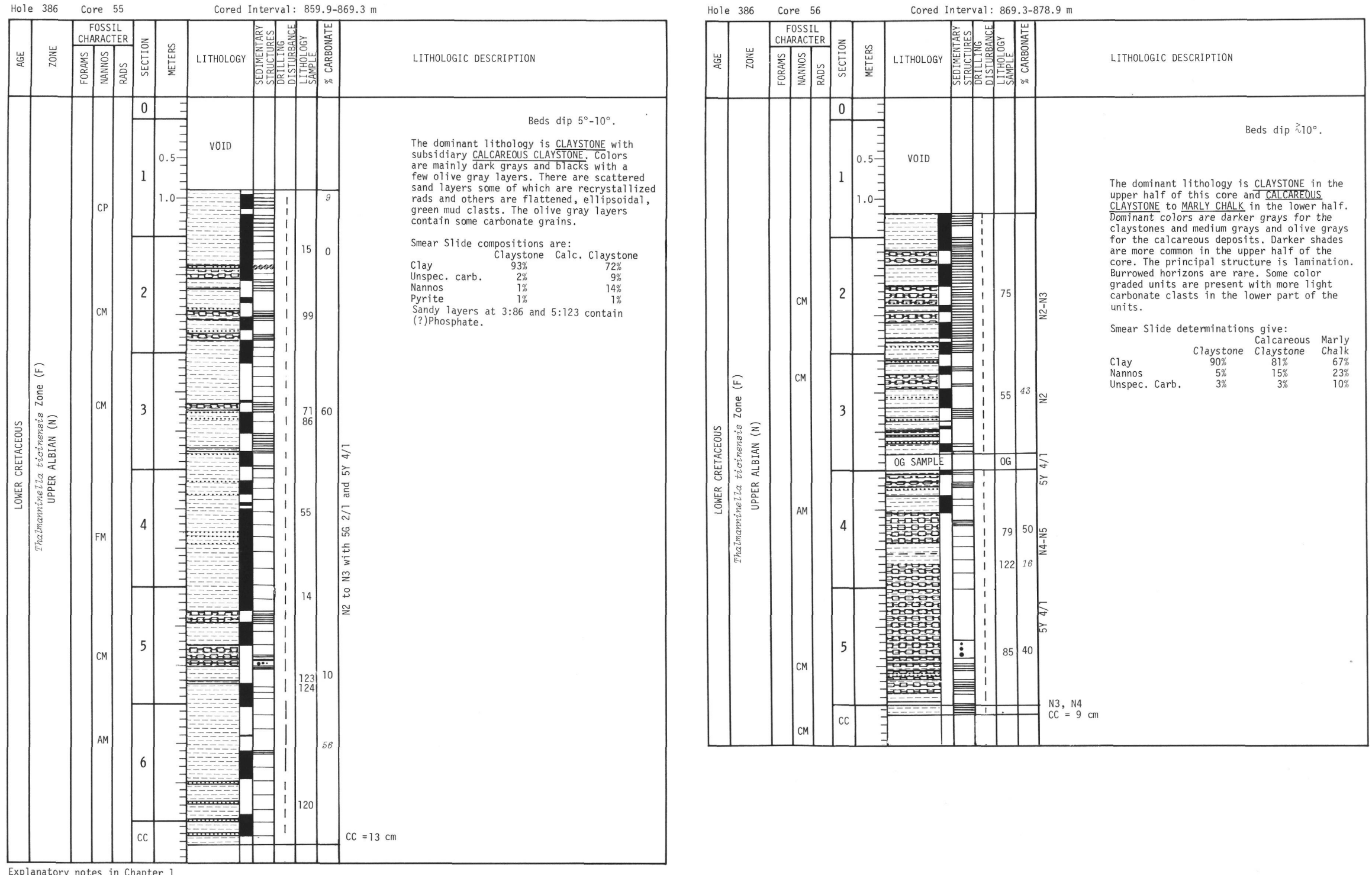

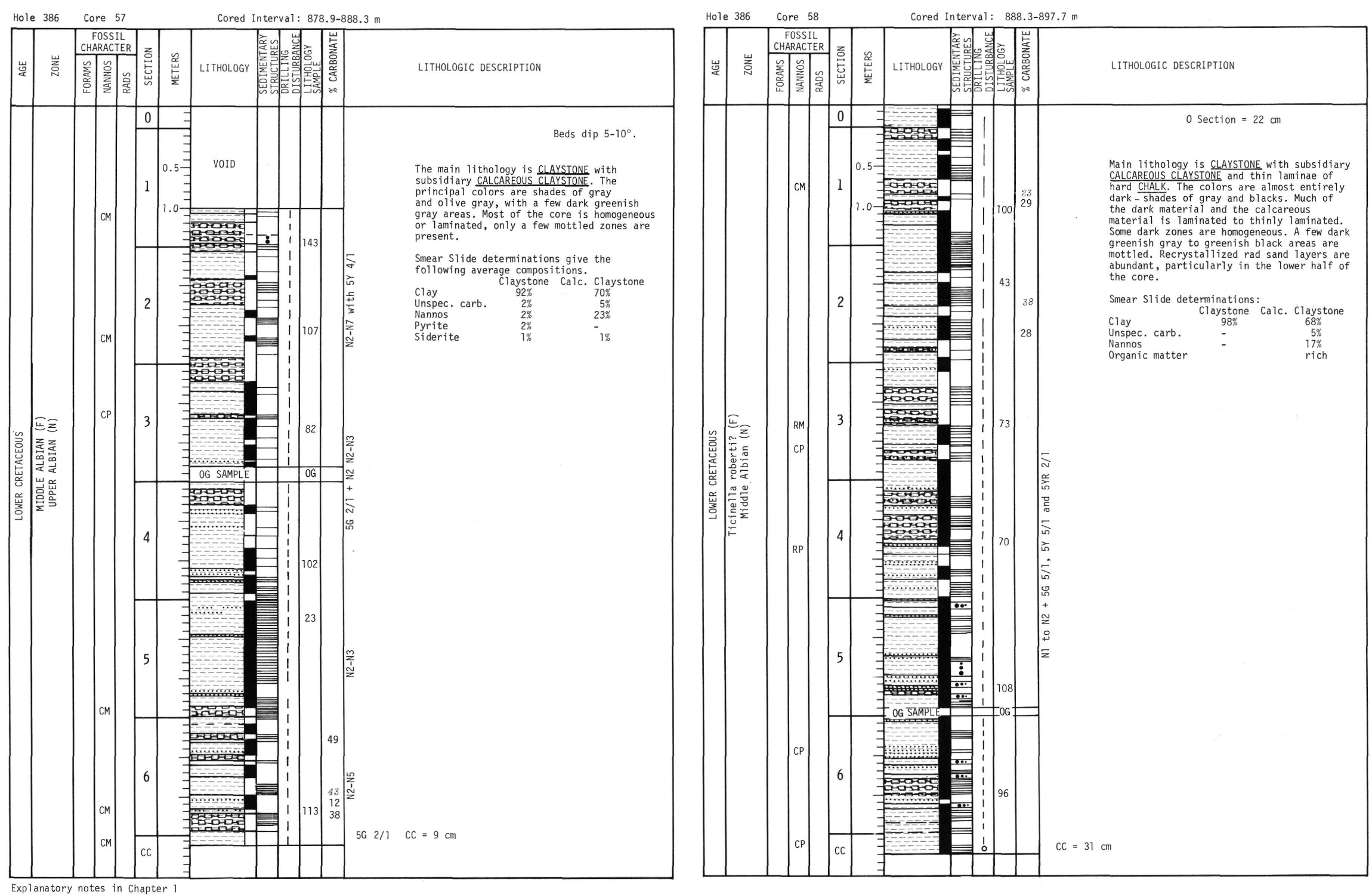

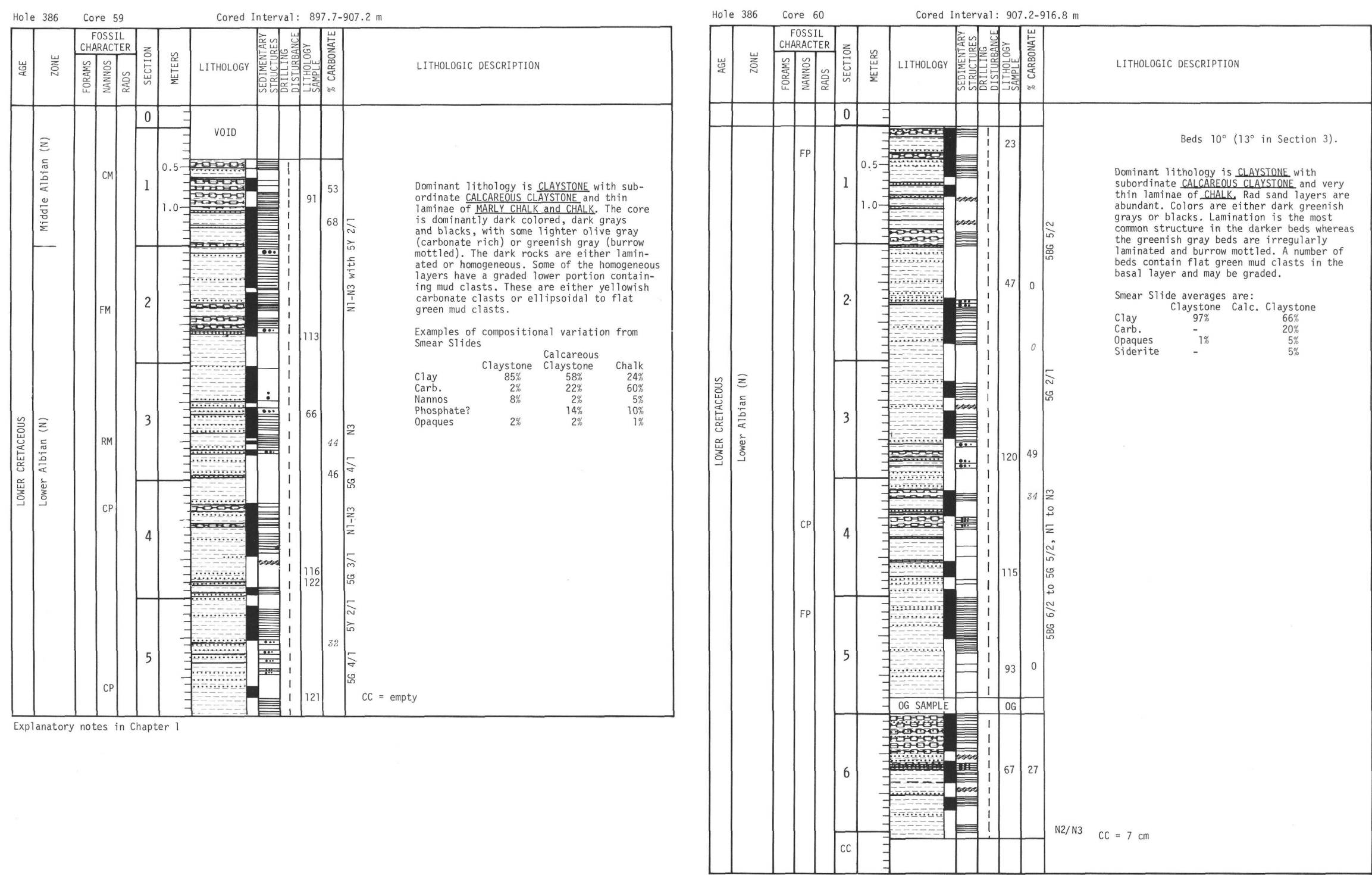


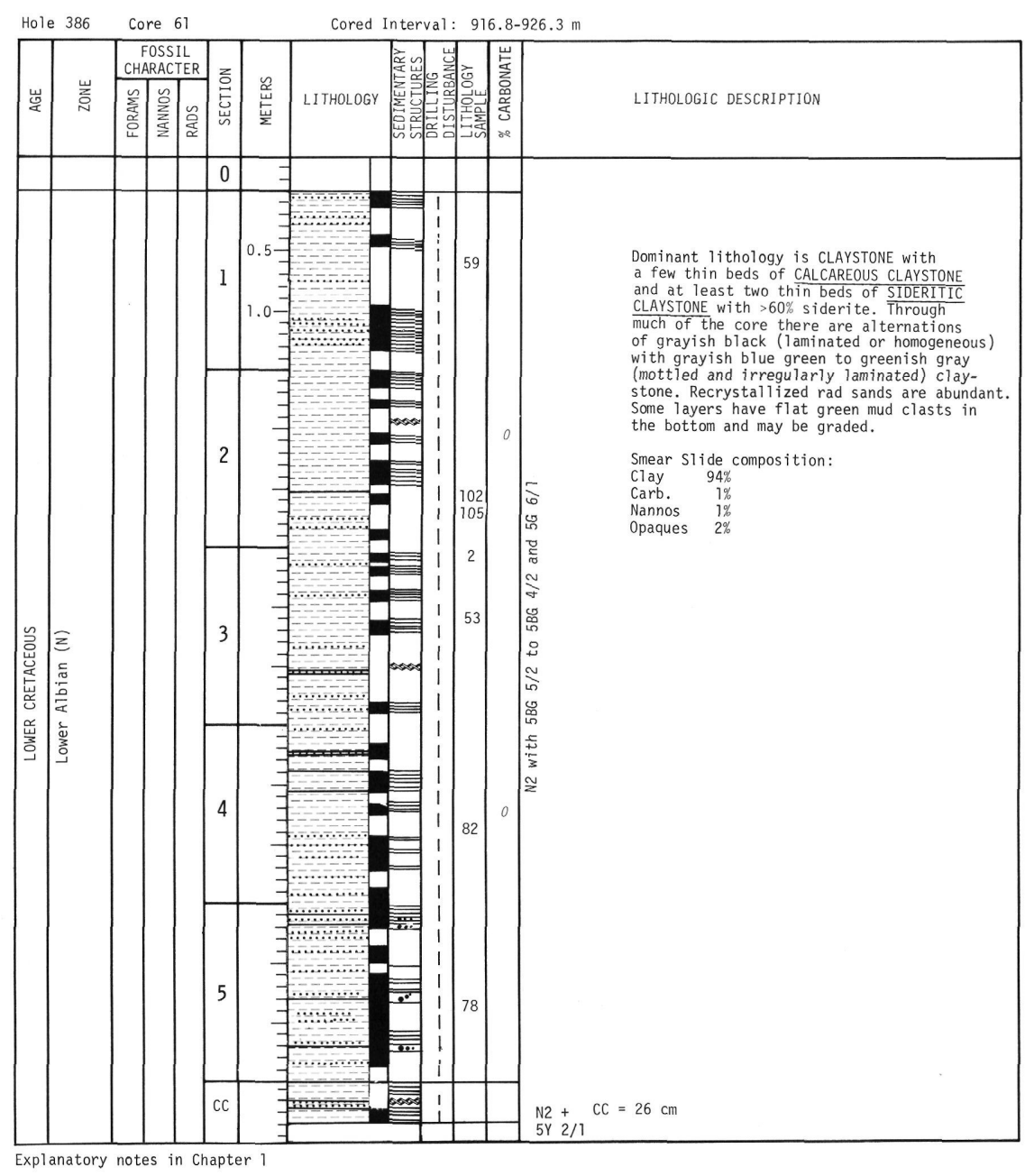

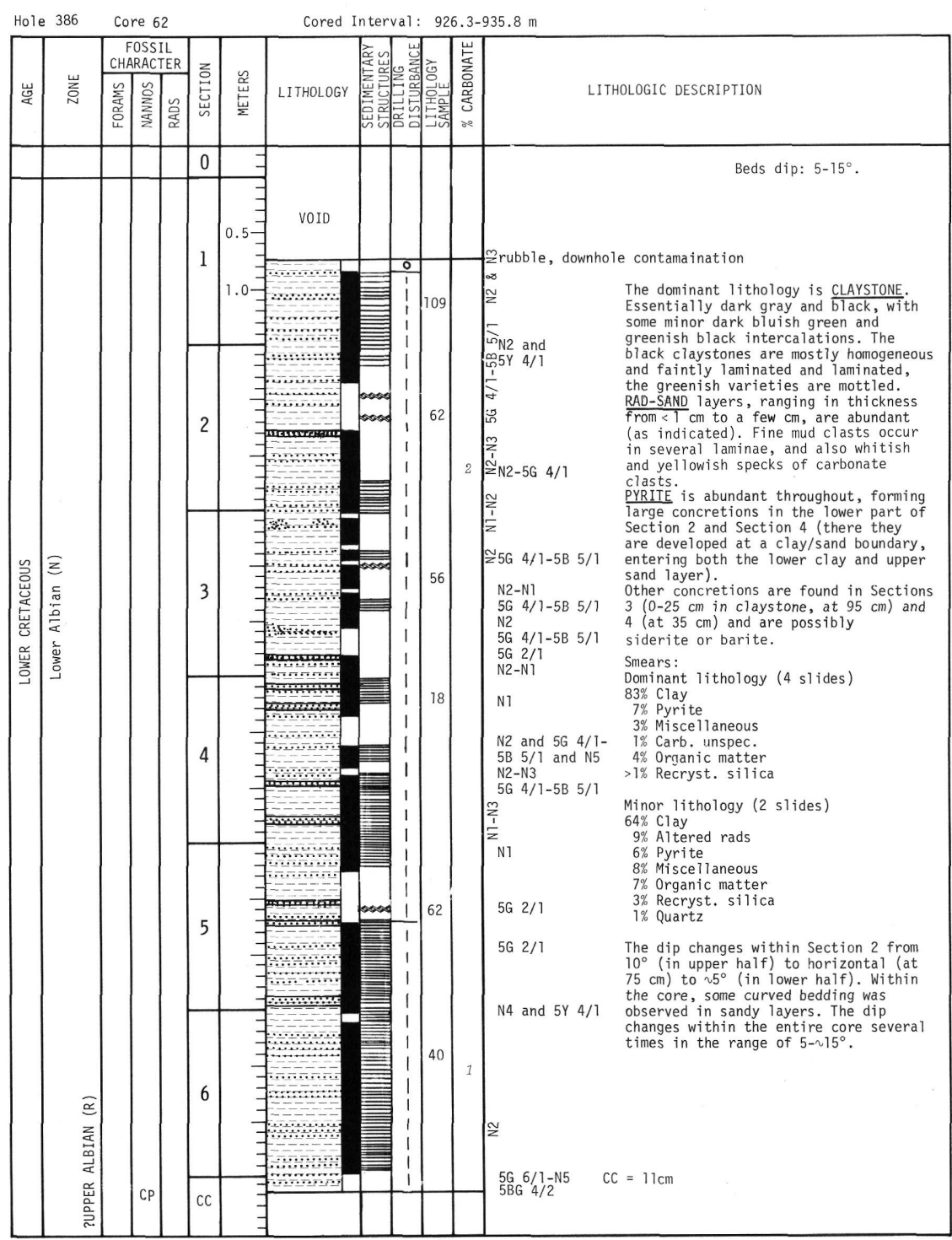




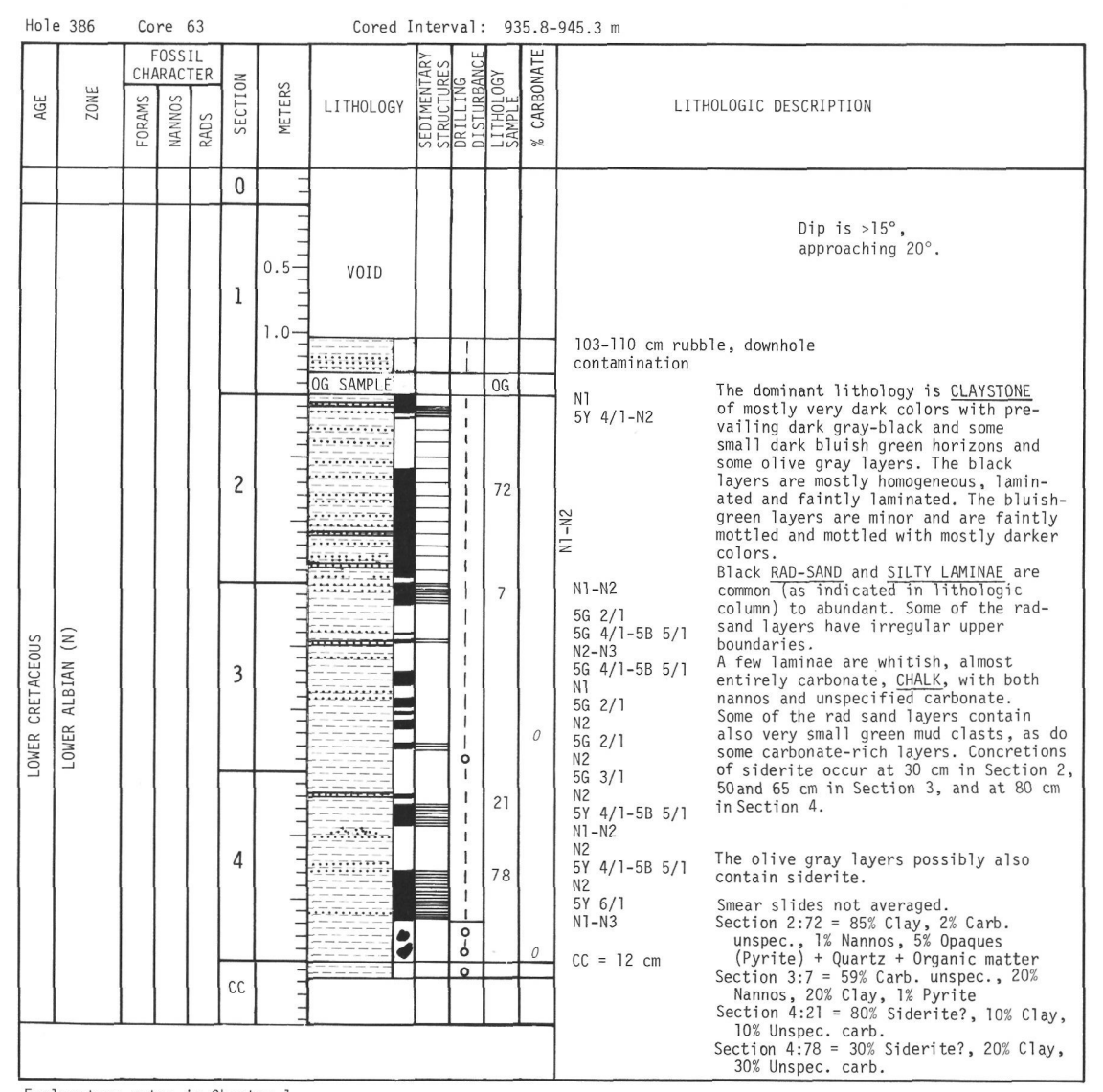

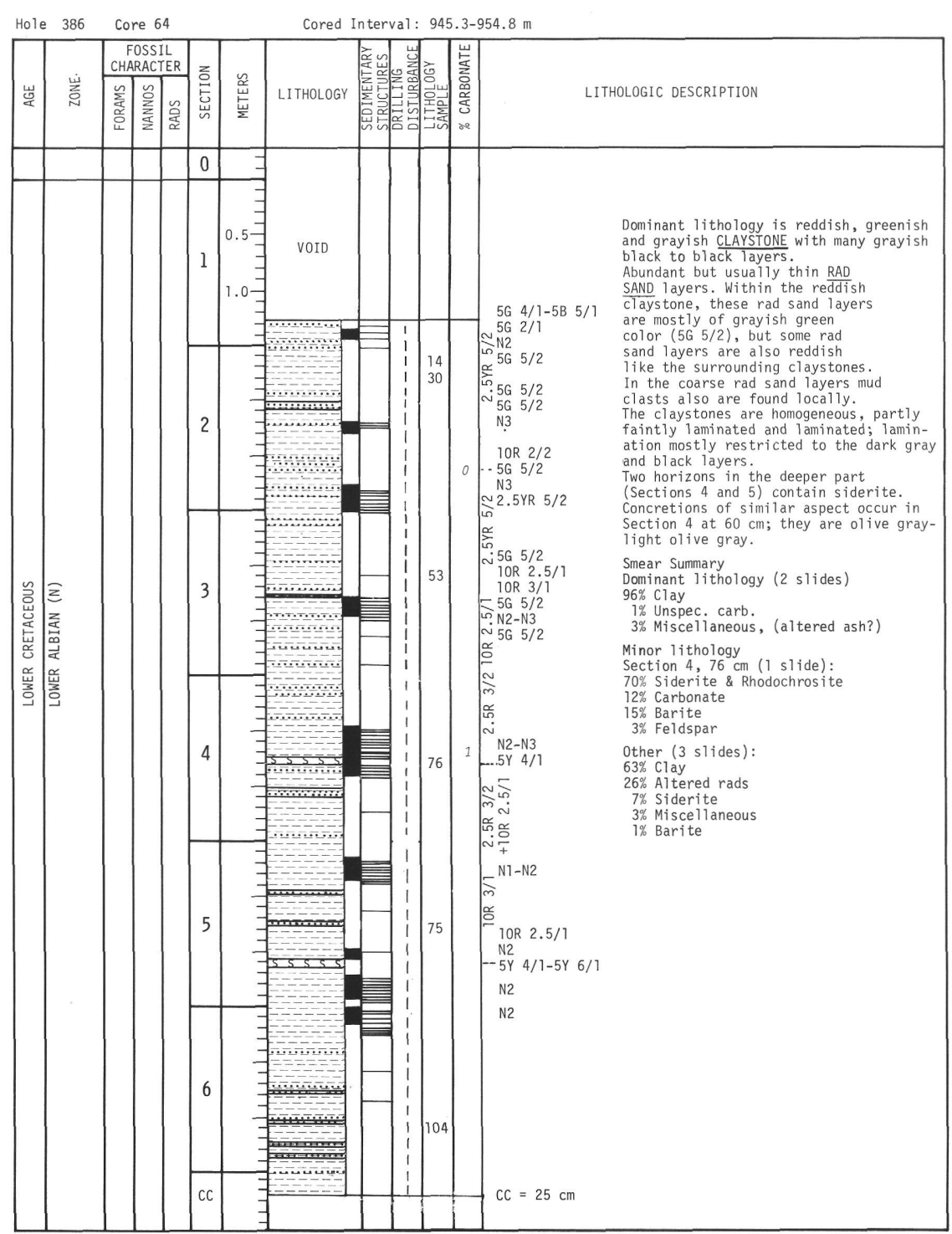




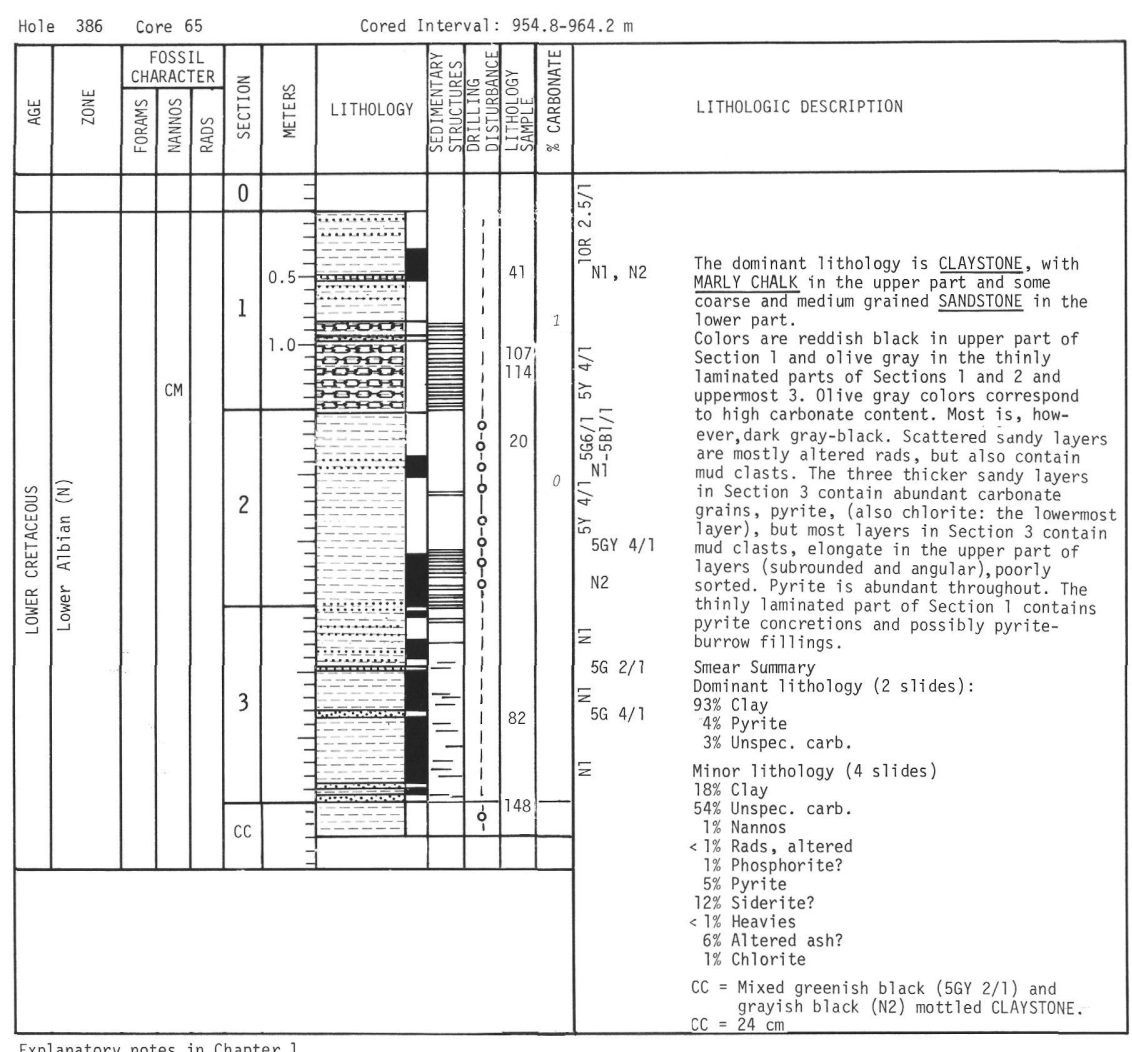

Explanatory notes in Chapter 1

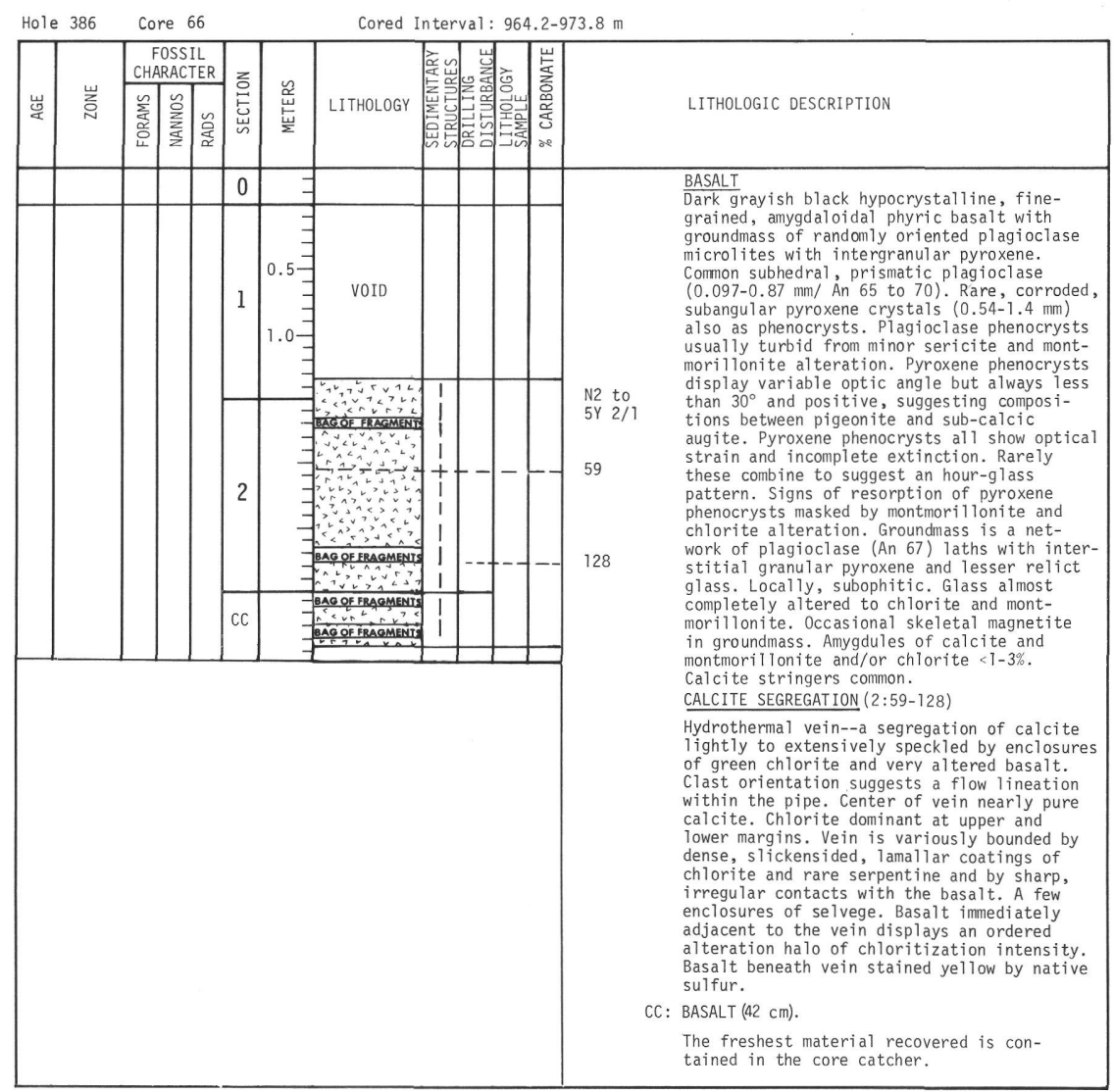




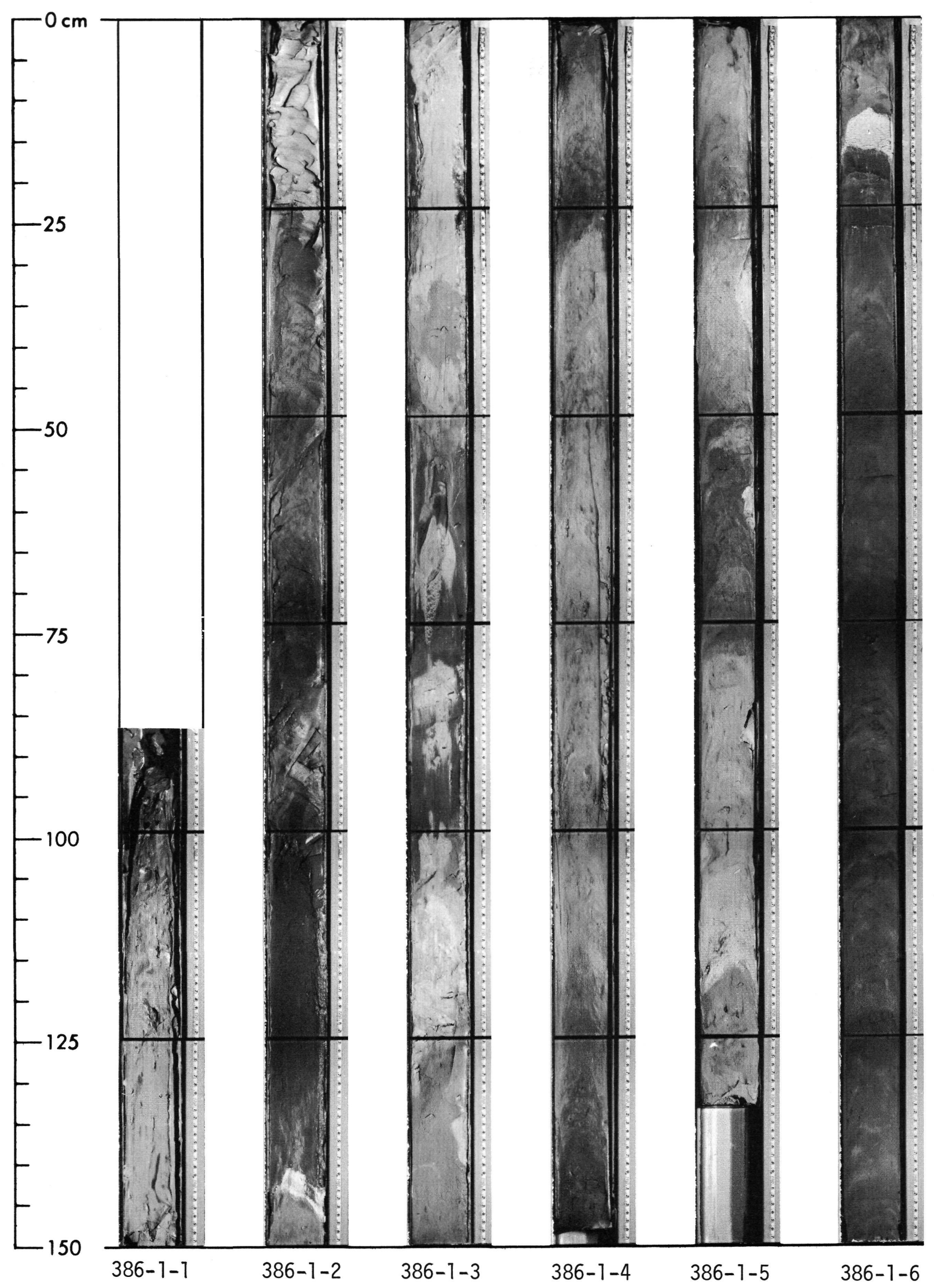




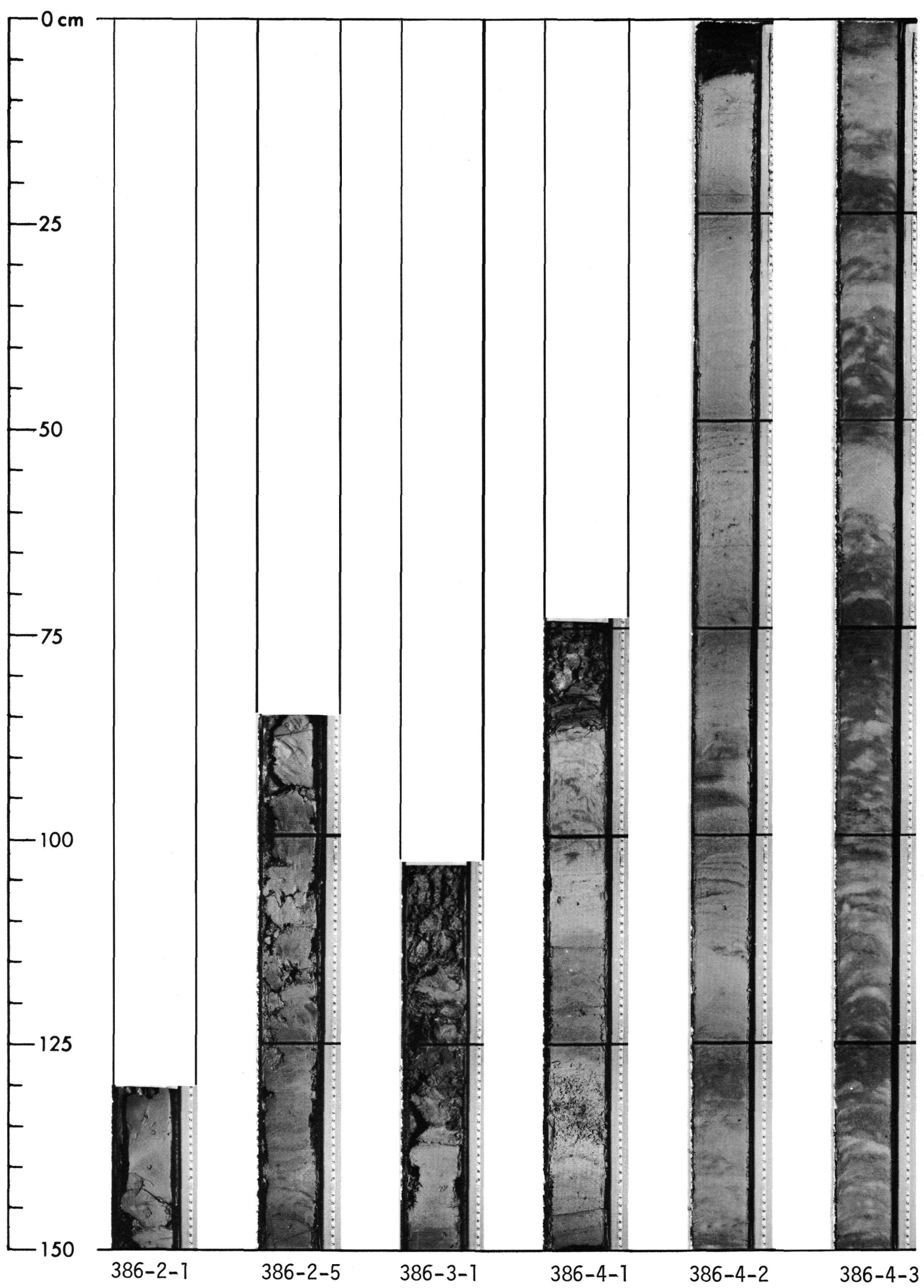




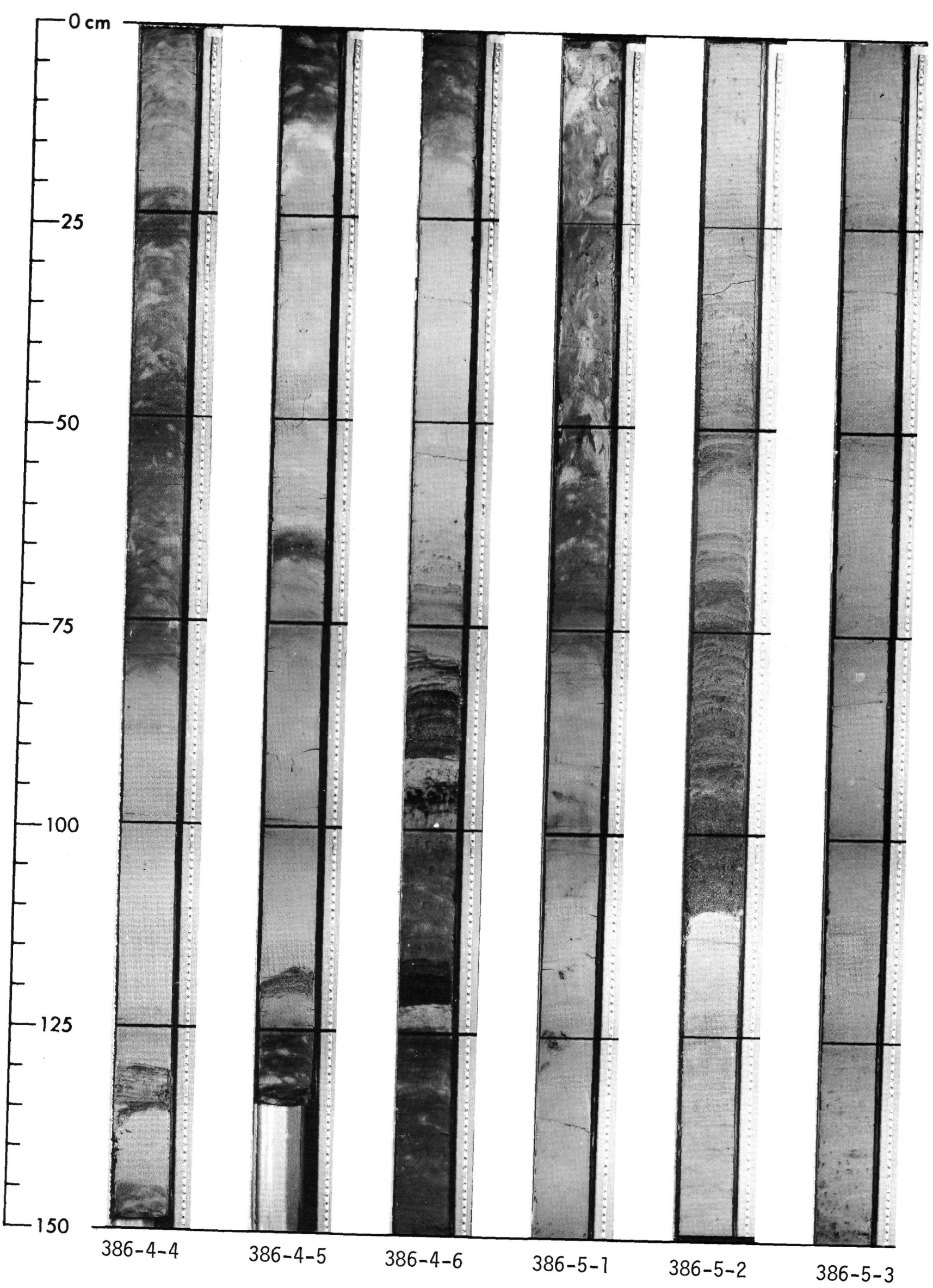




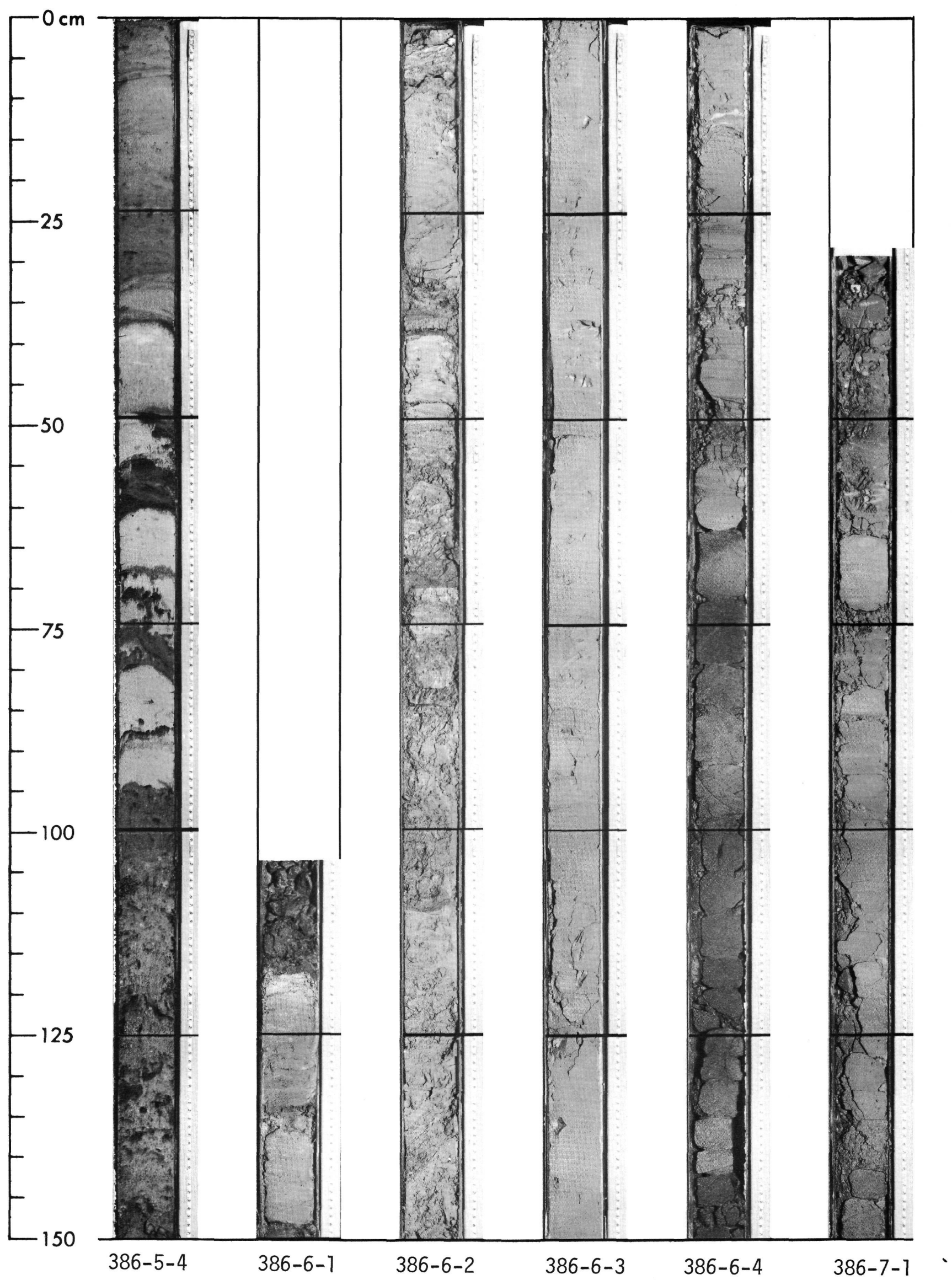




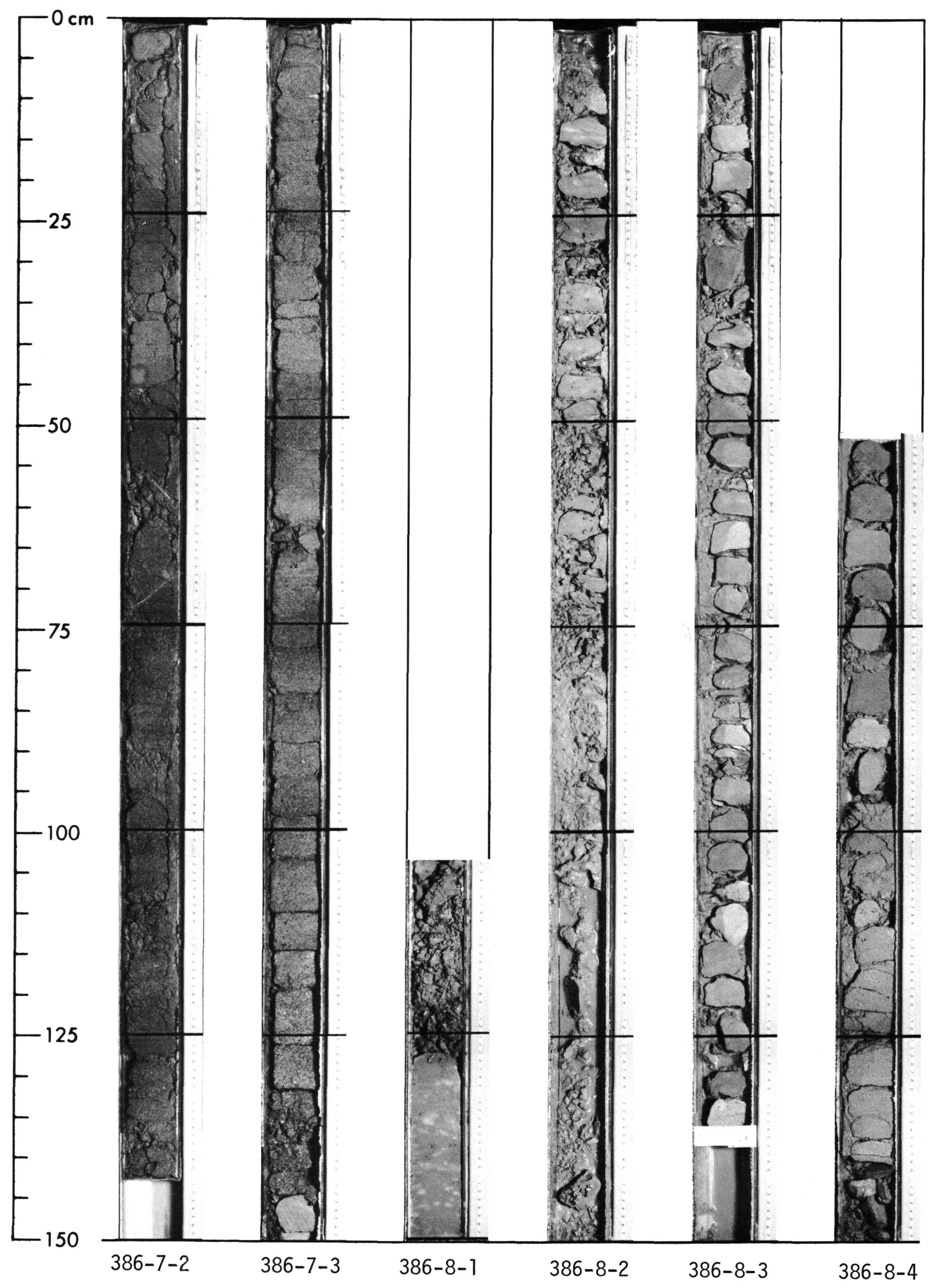




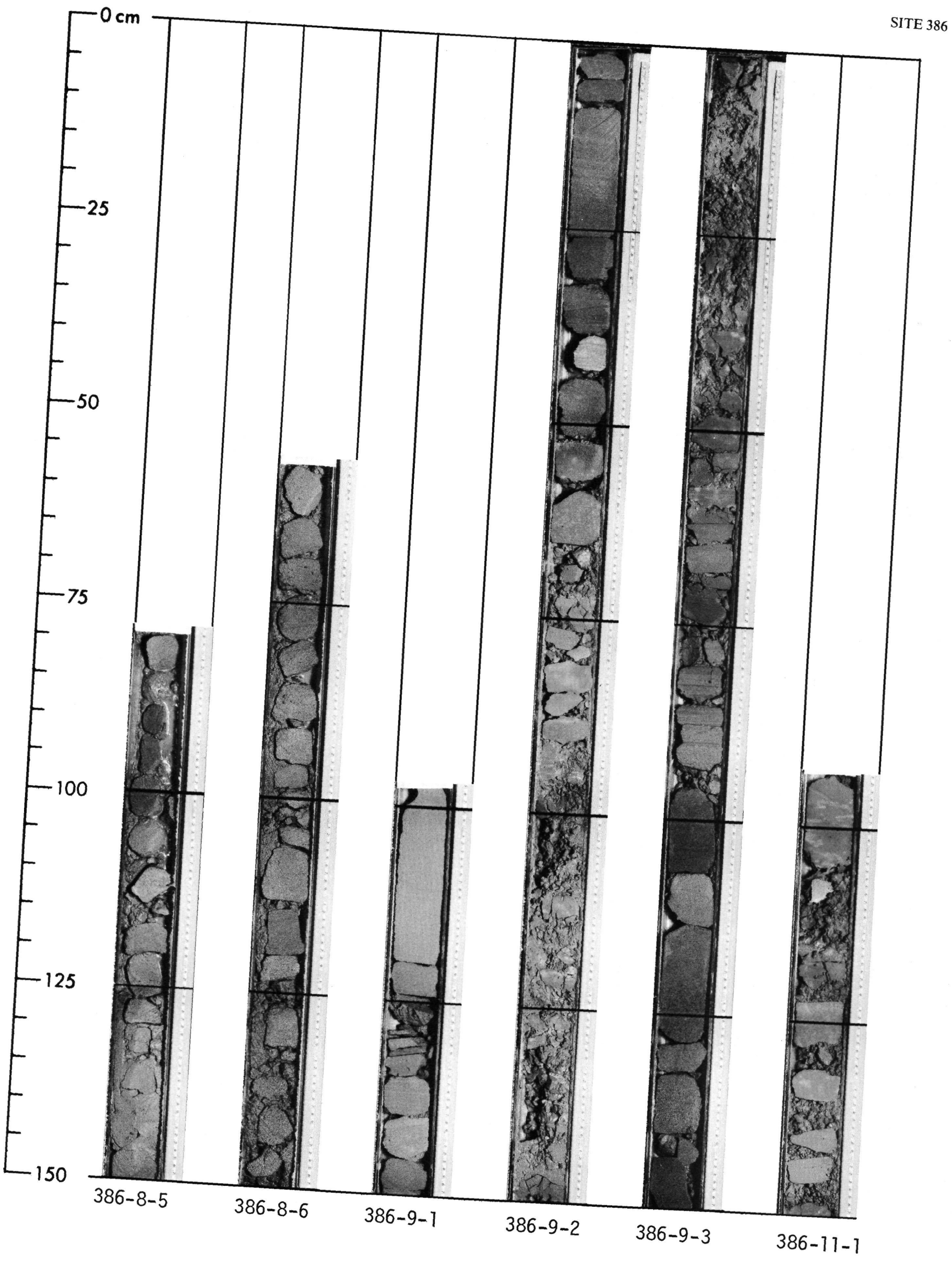




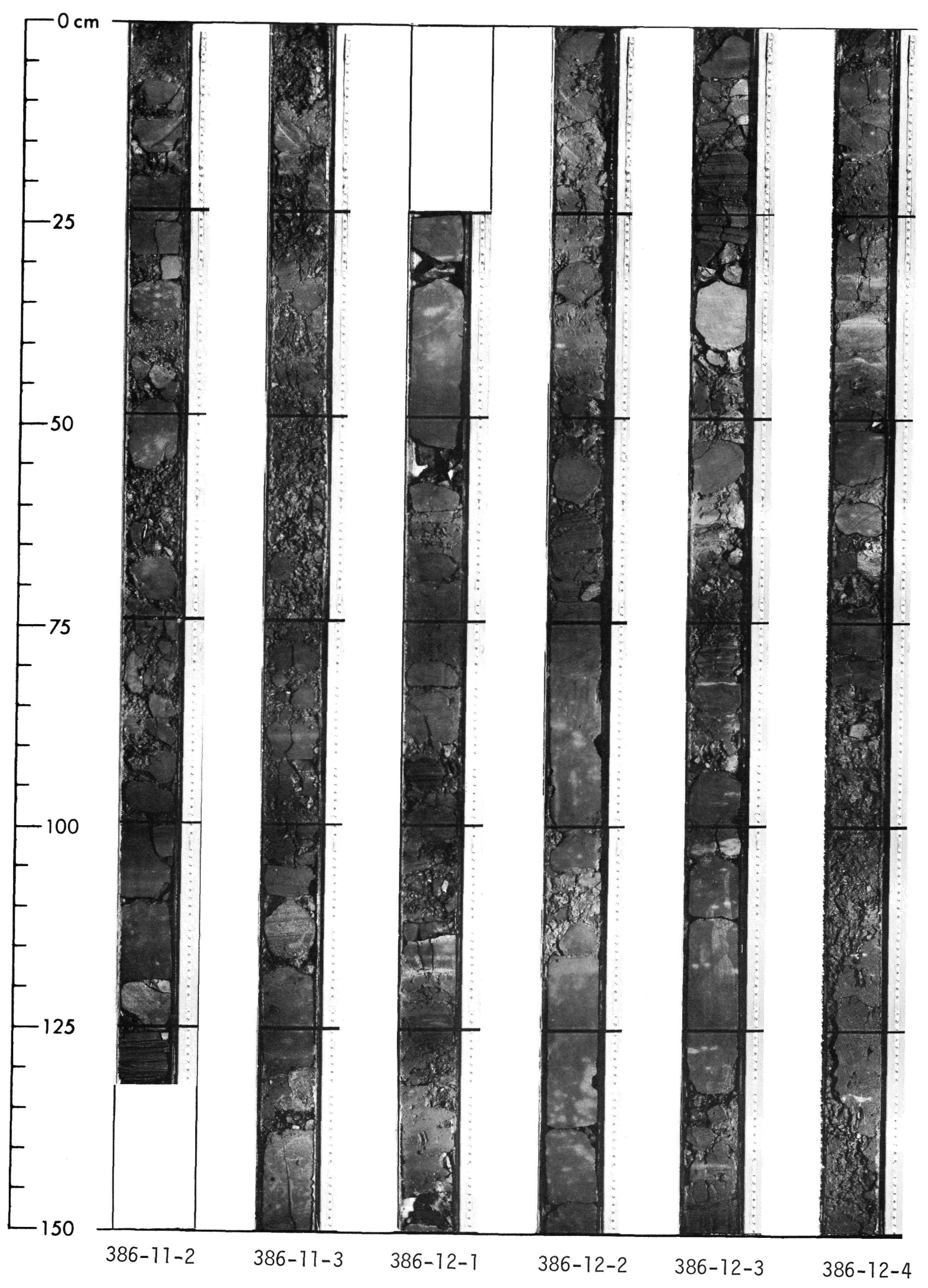


SITE 386

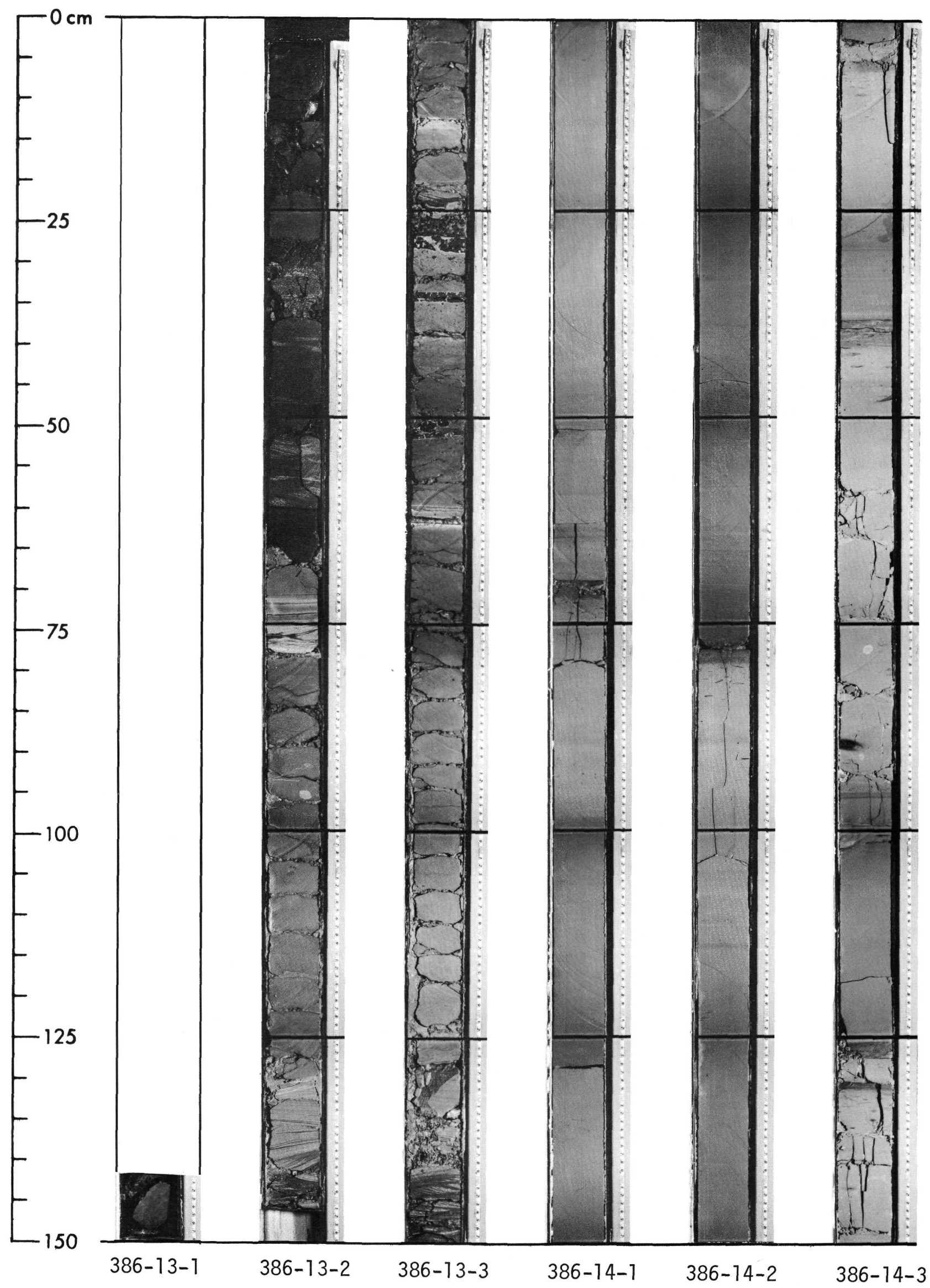




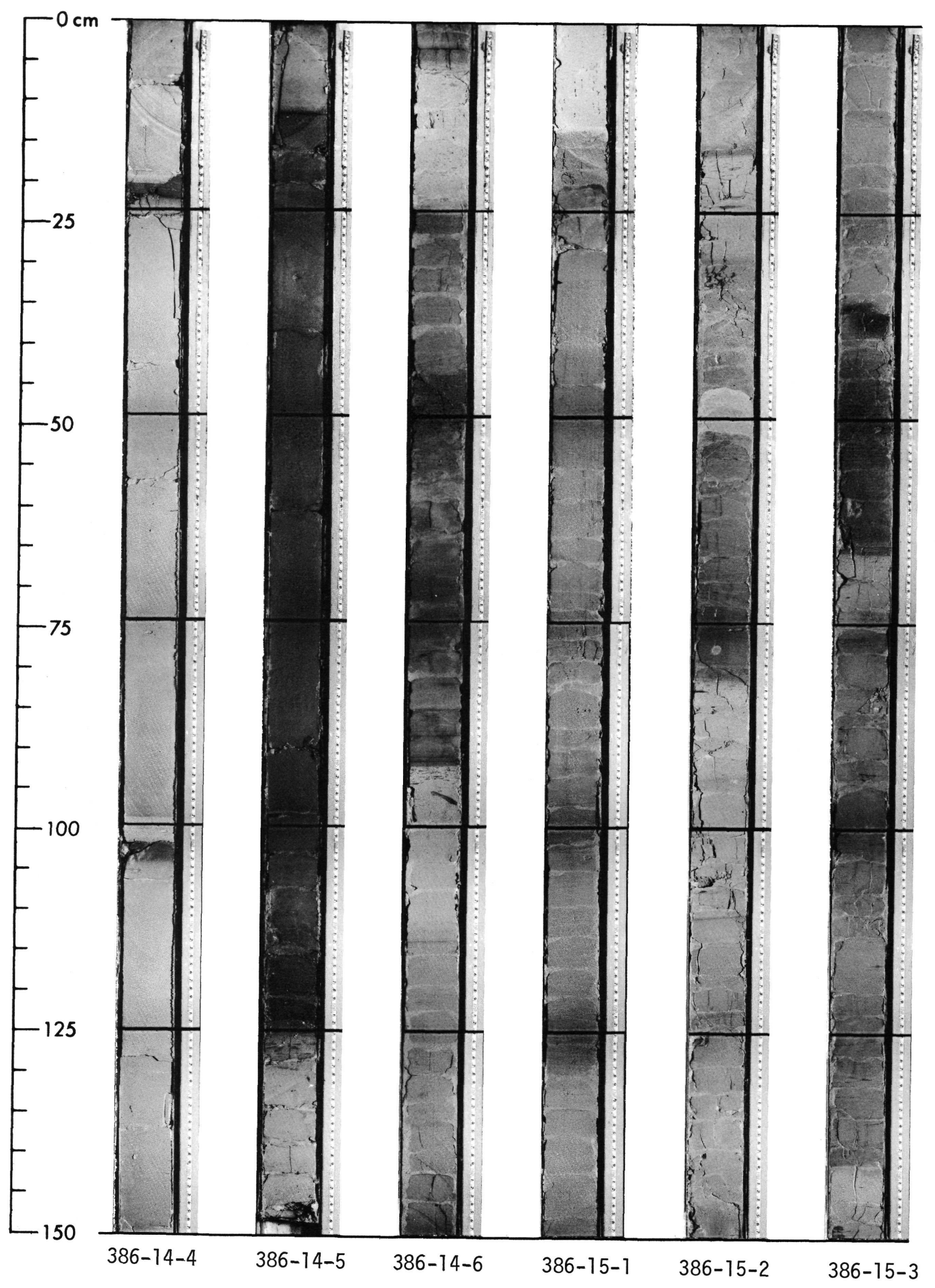




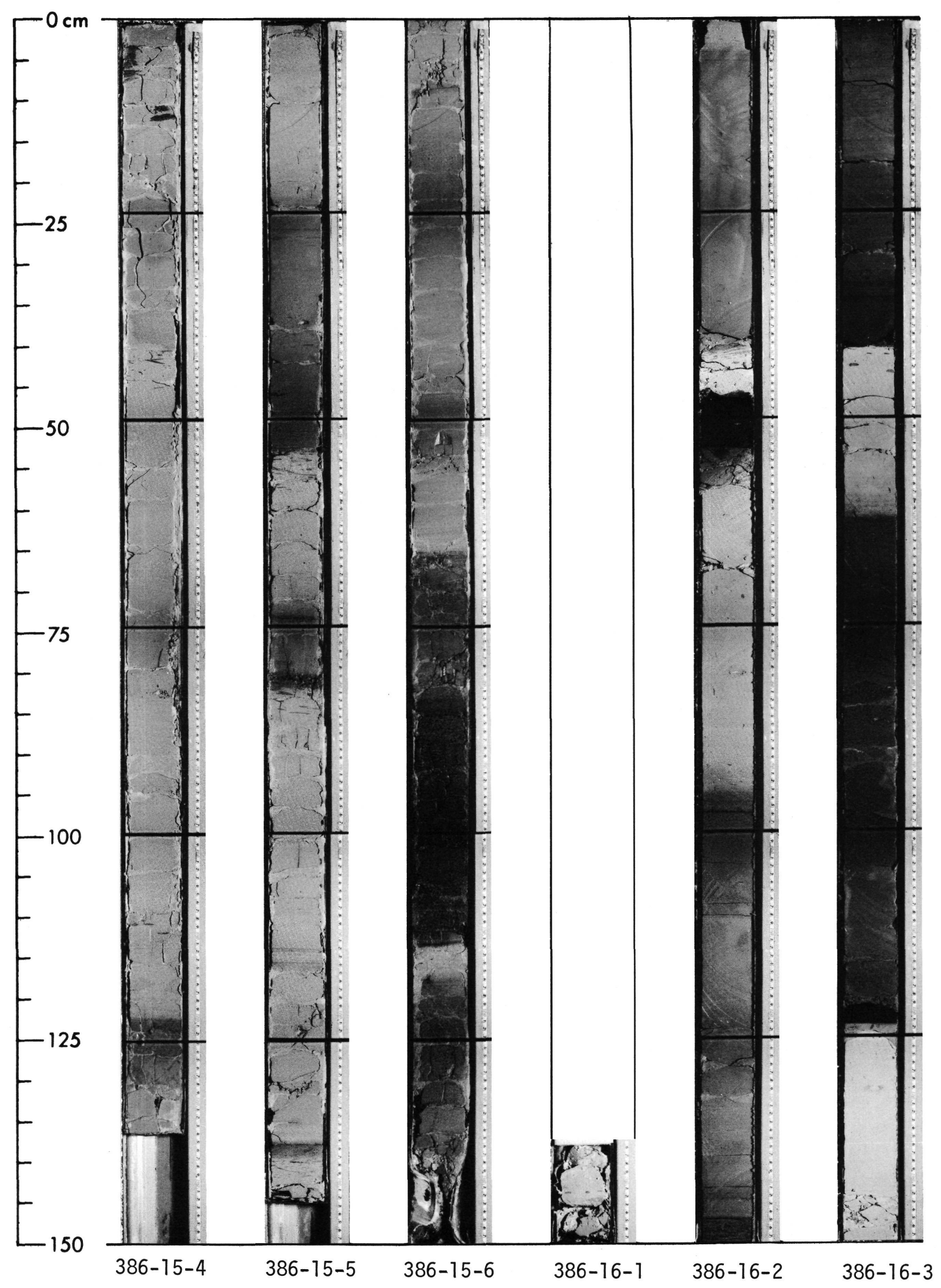




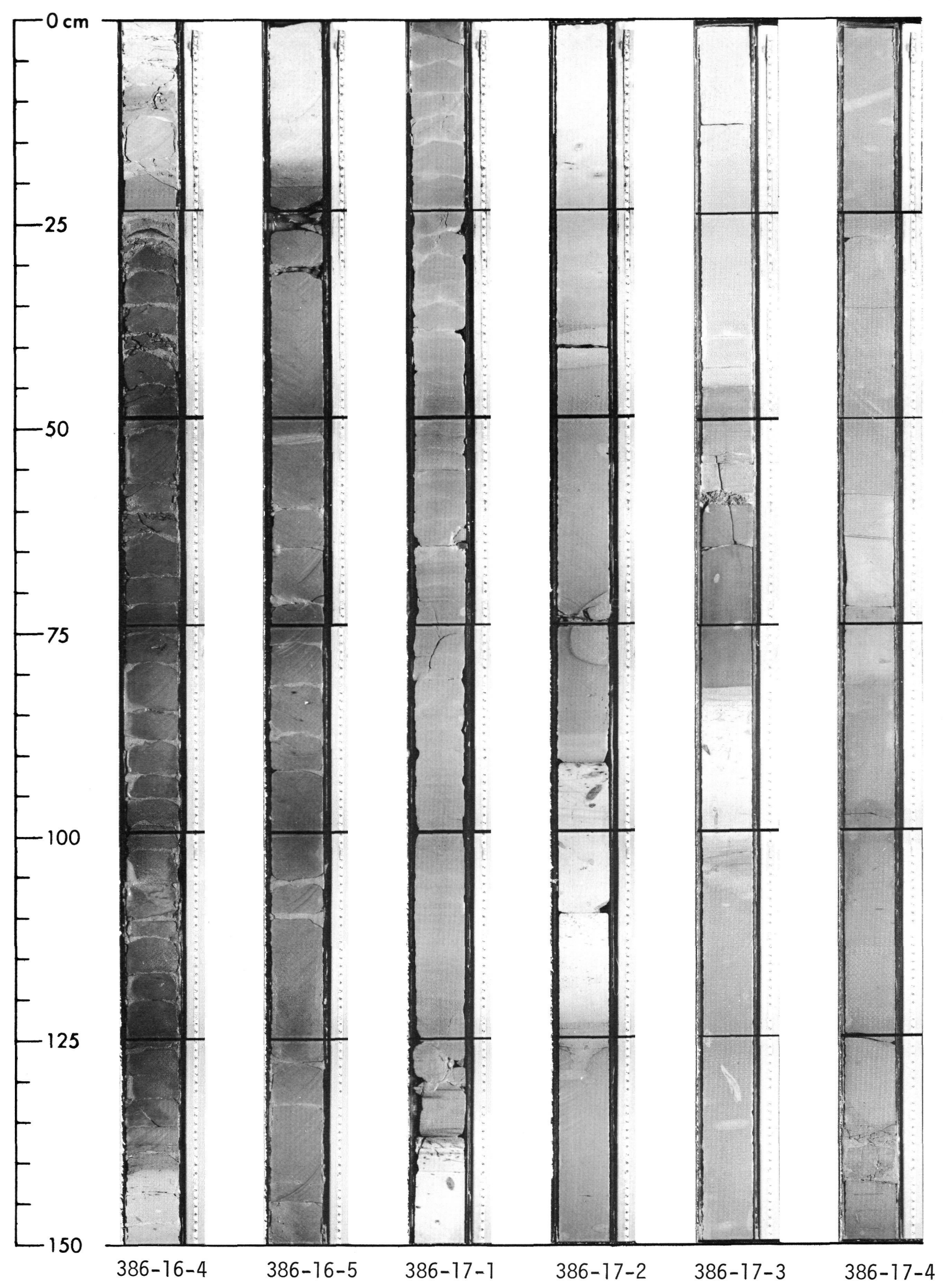




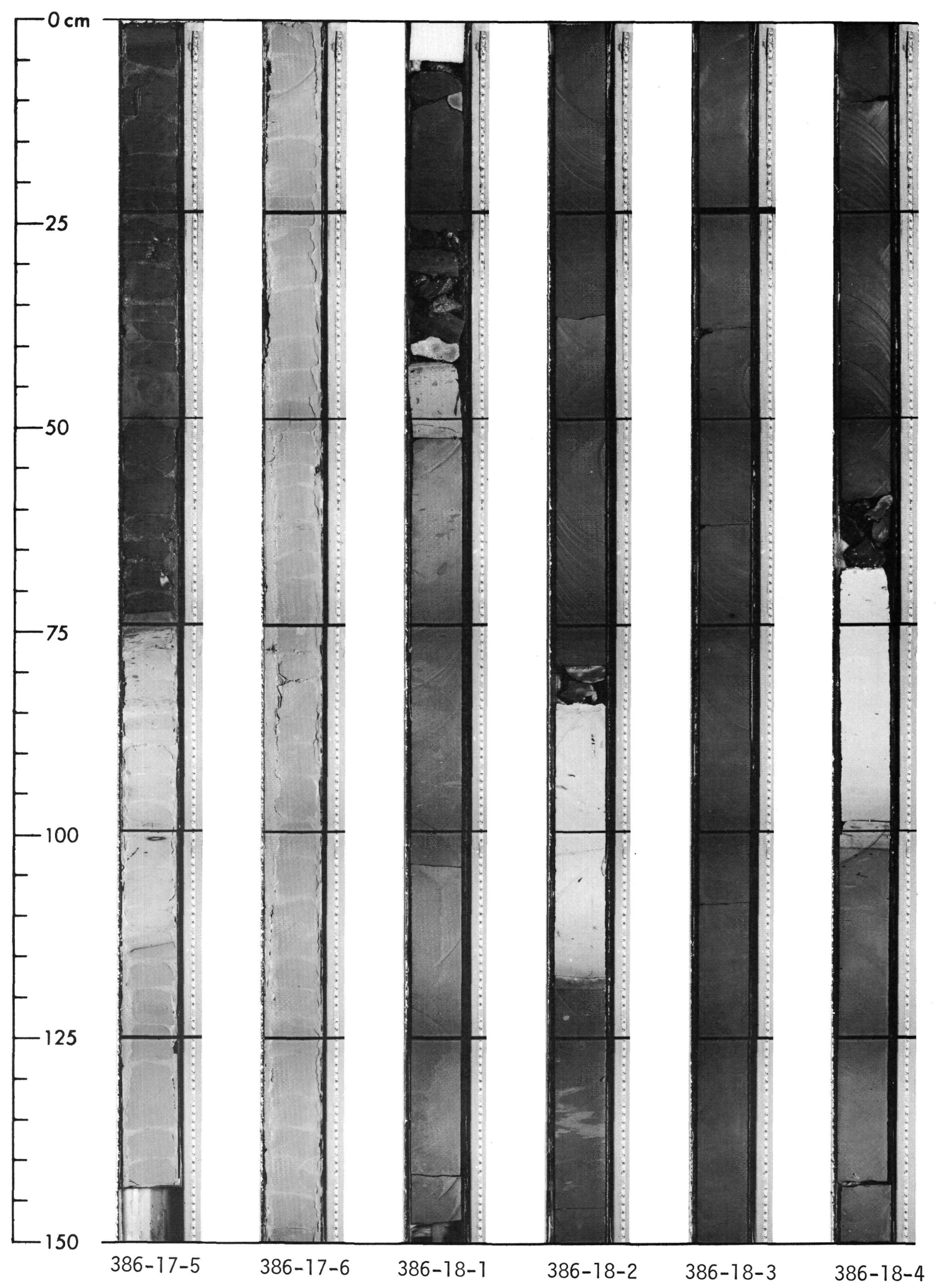




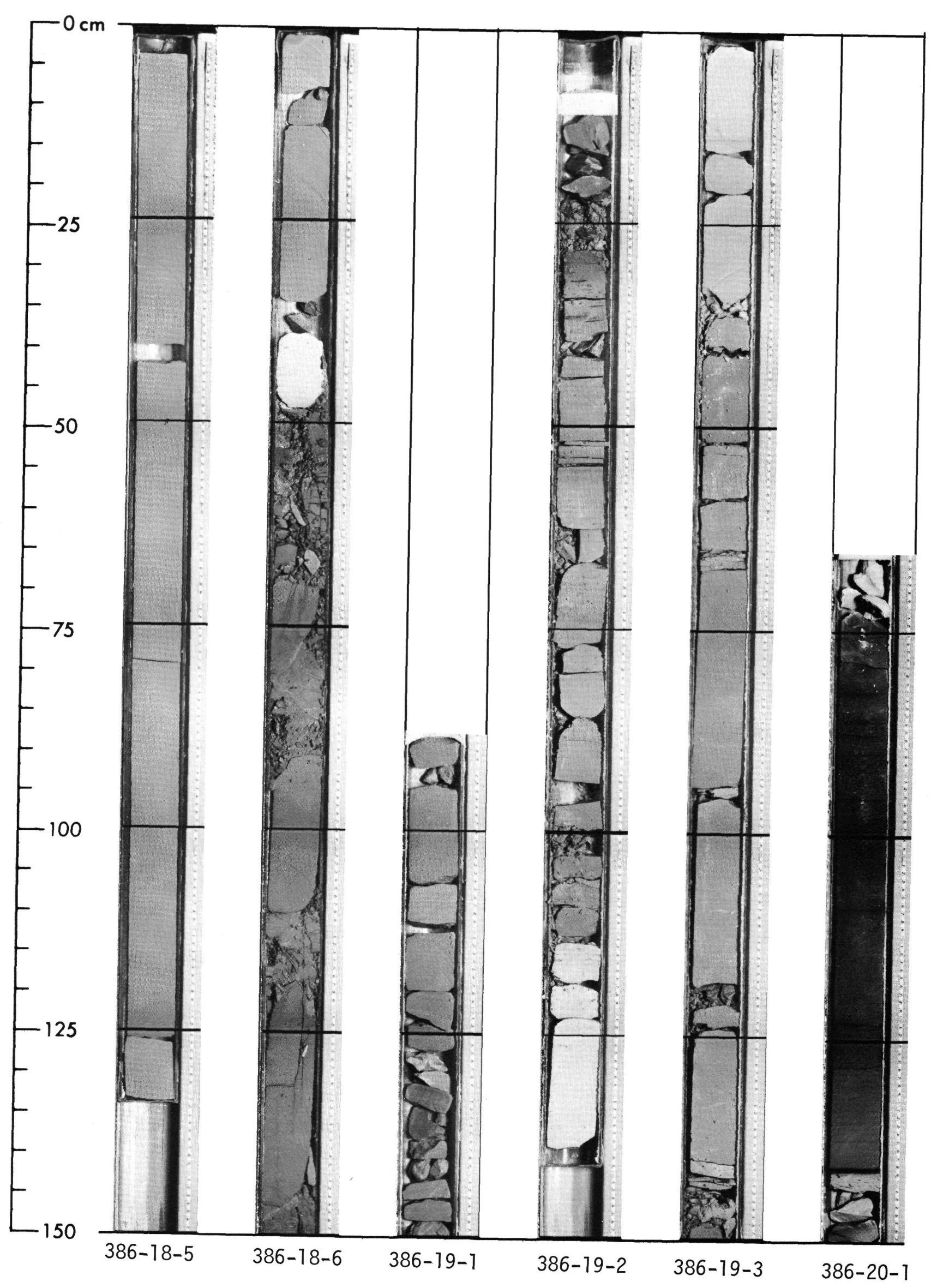




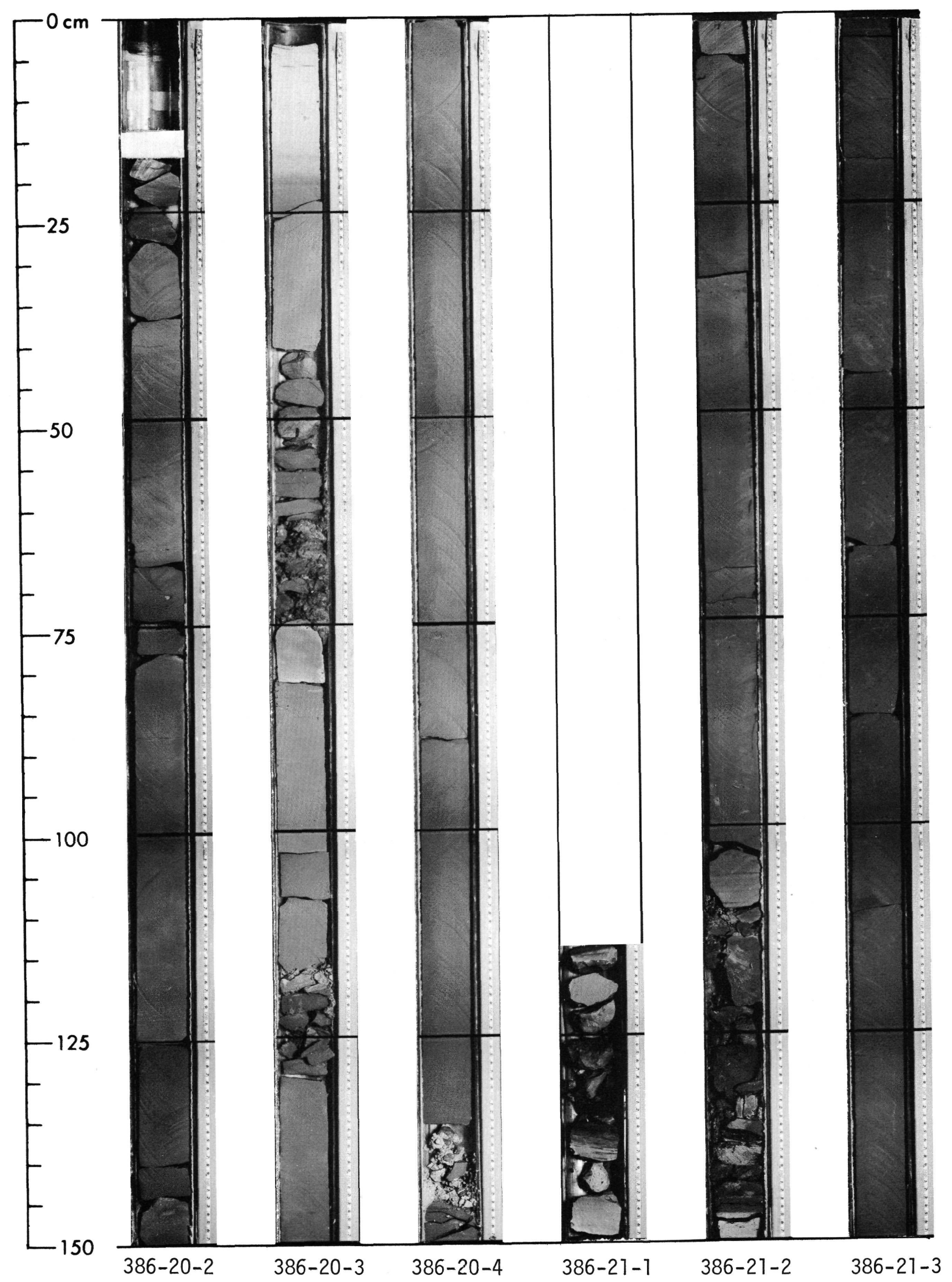




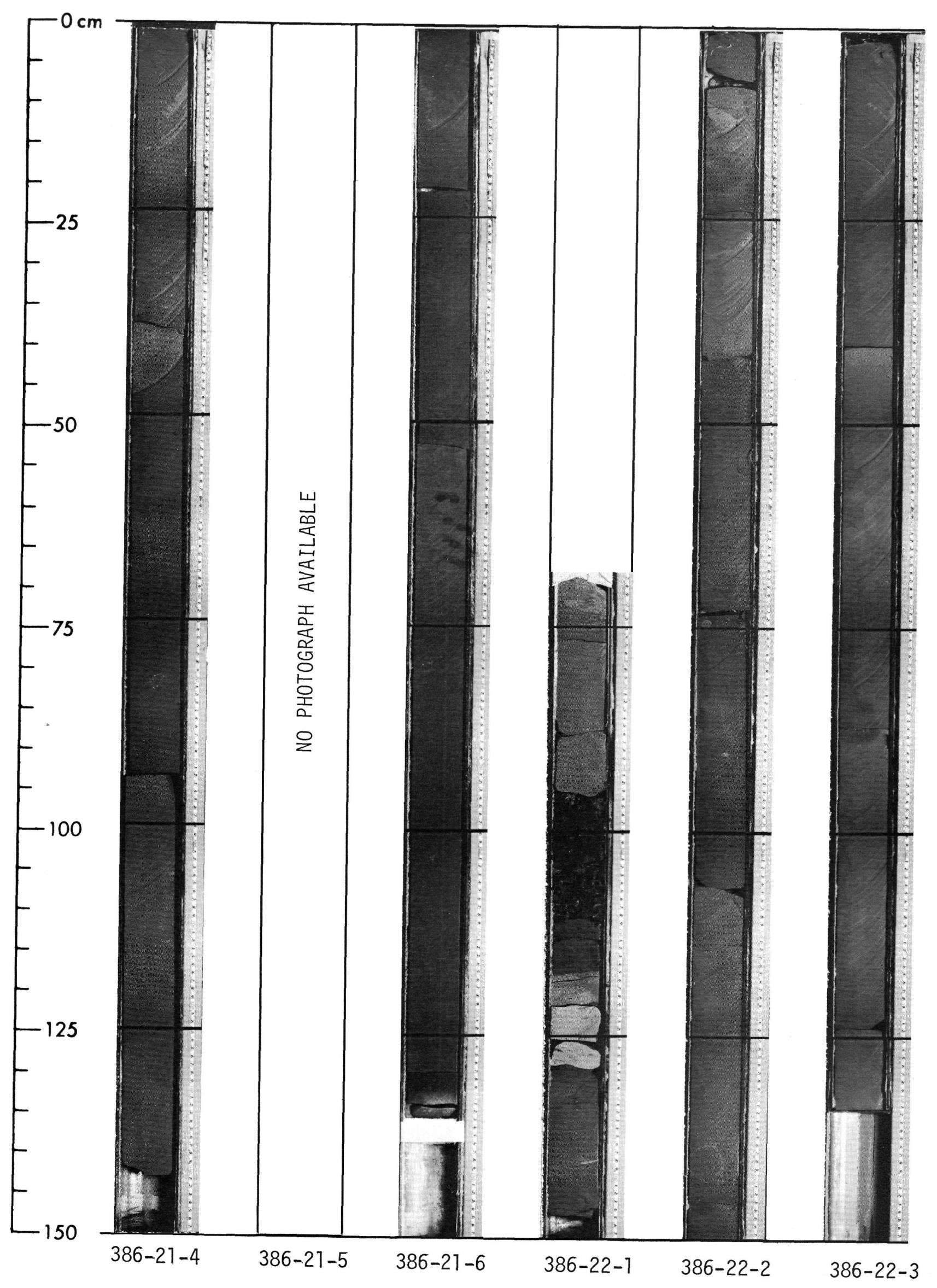




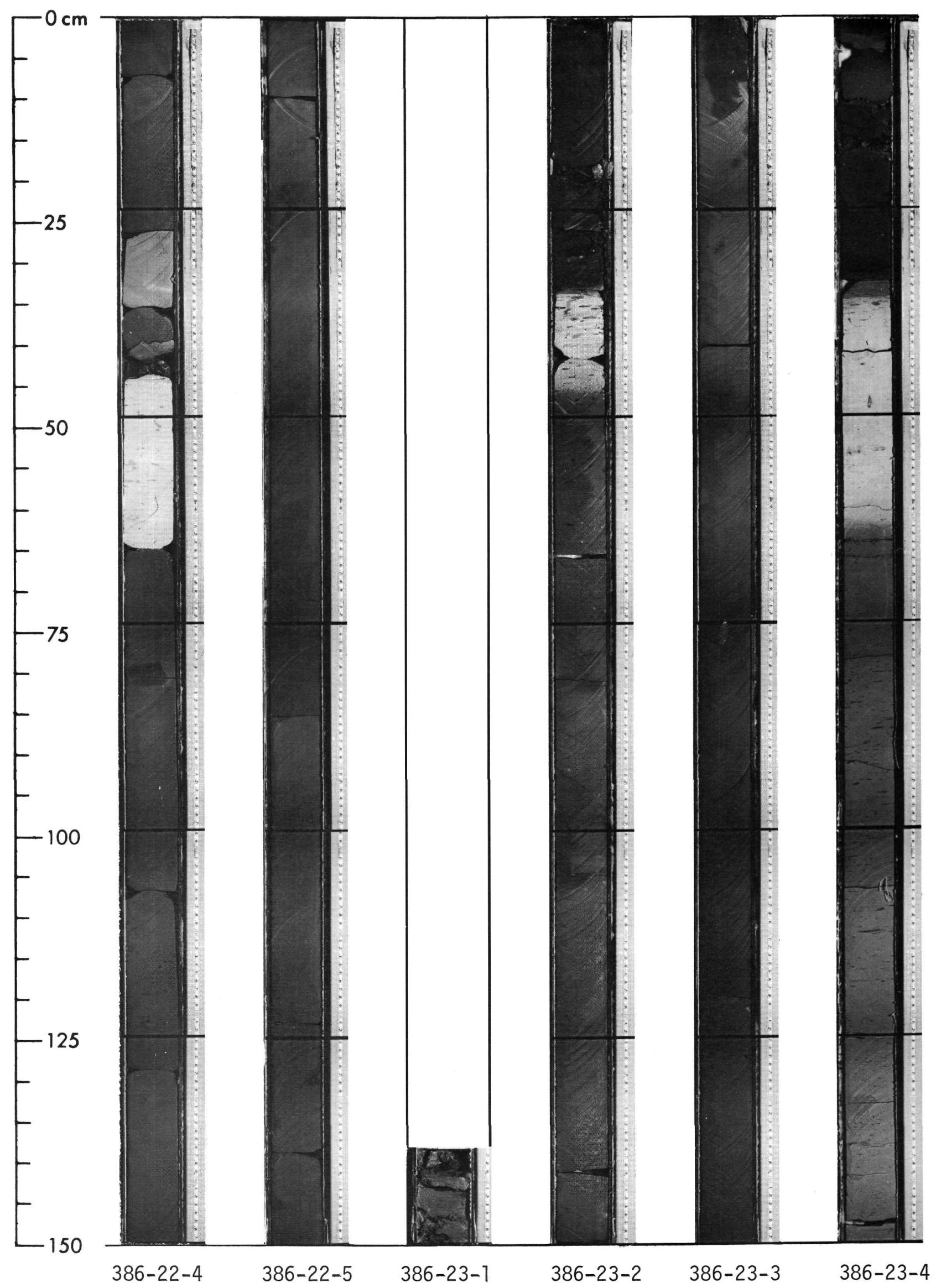




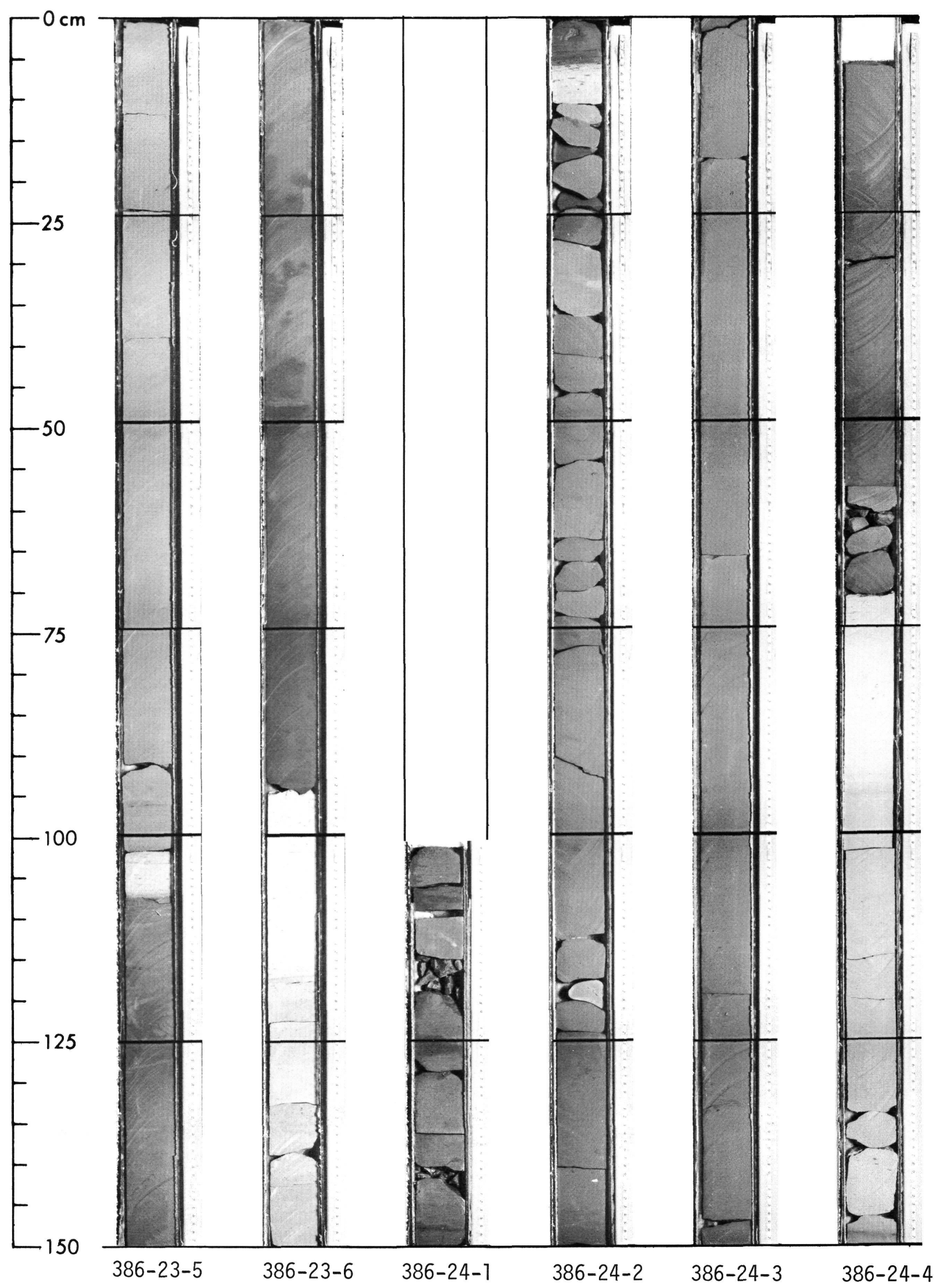




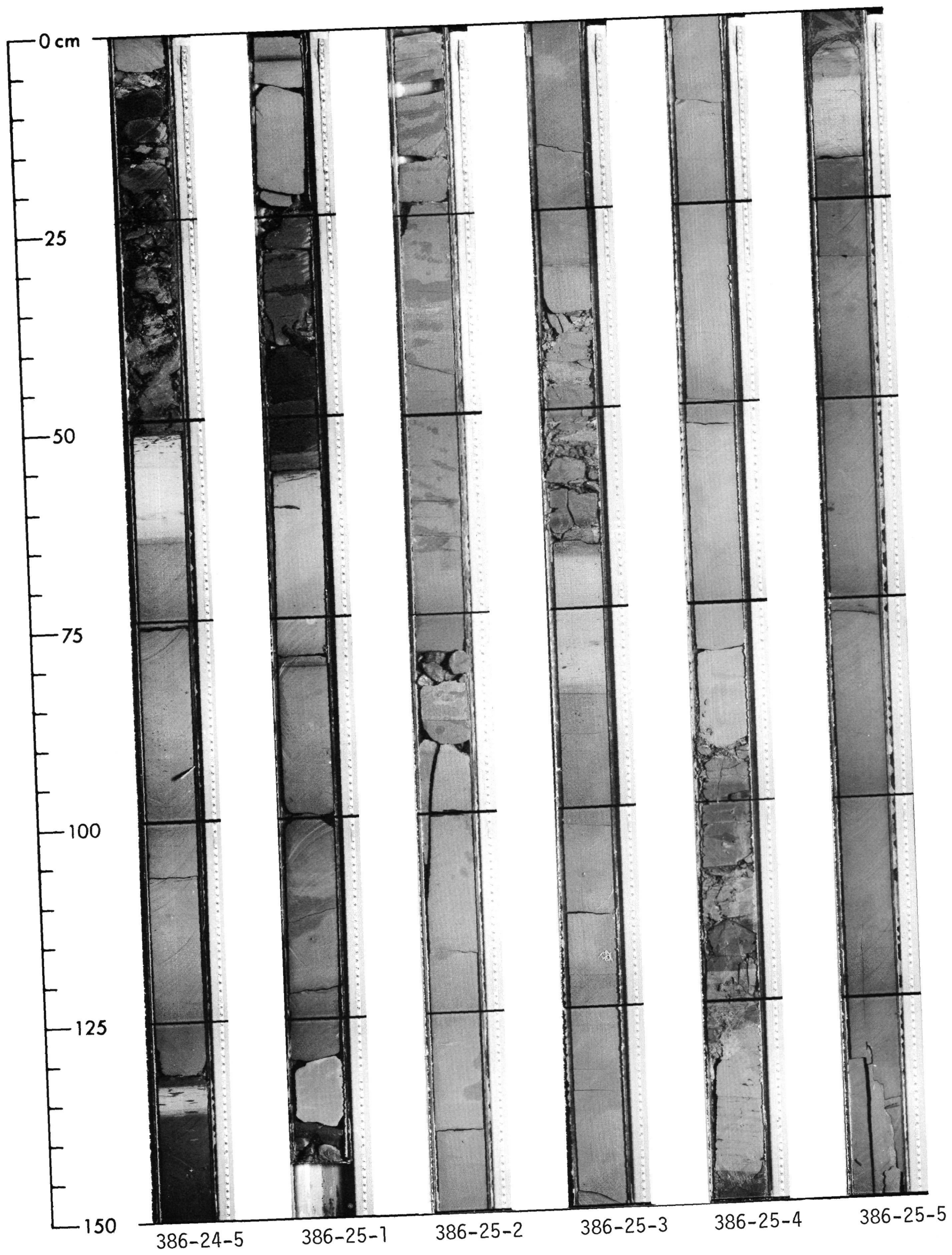




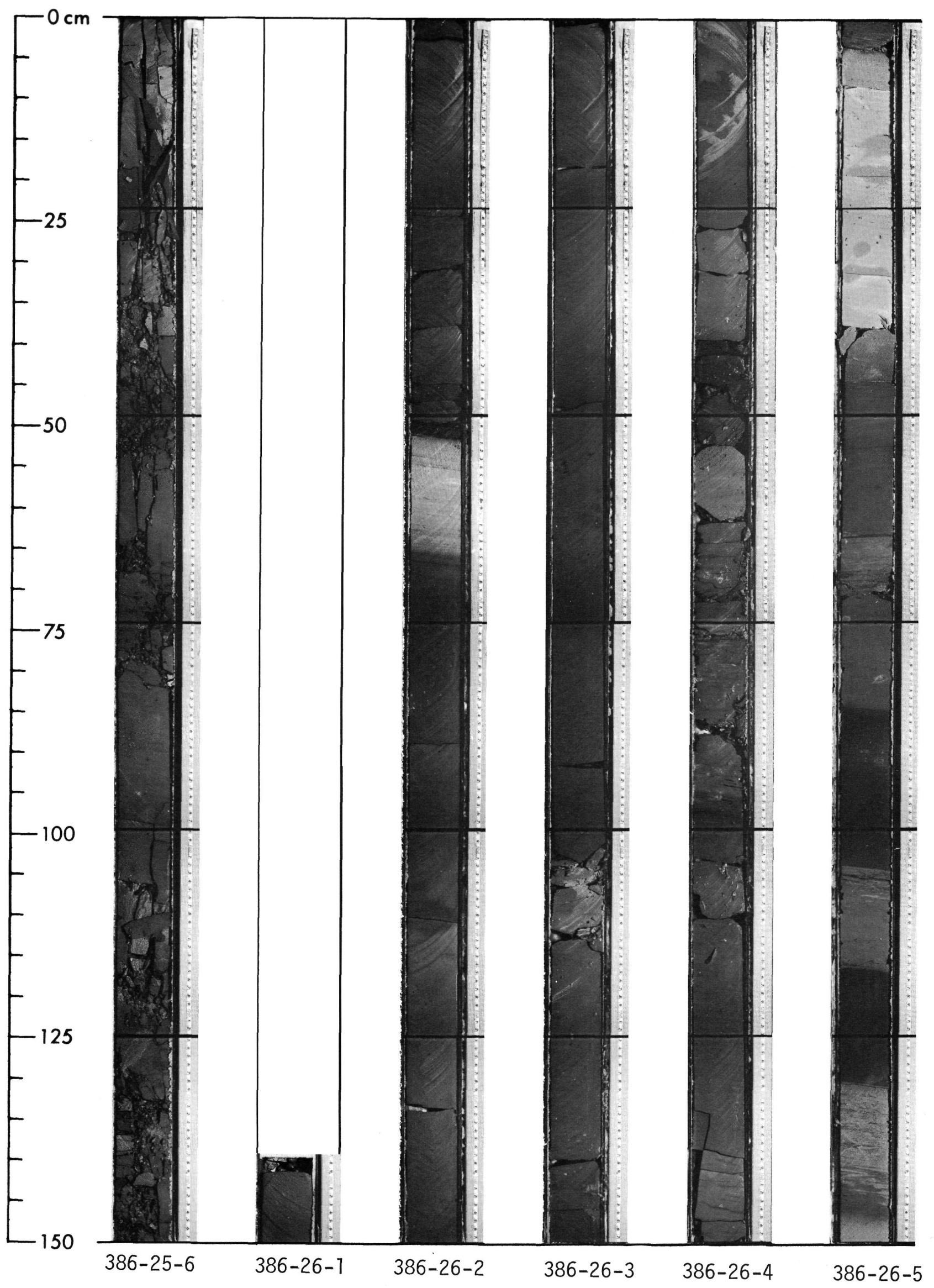




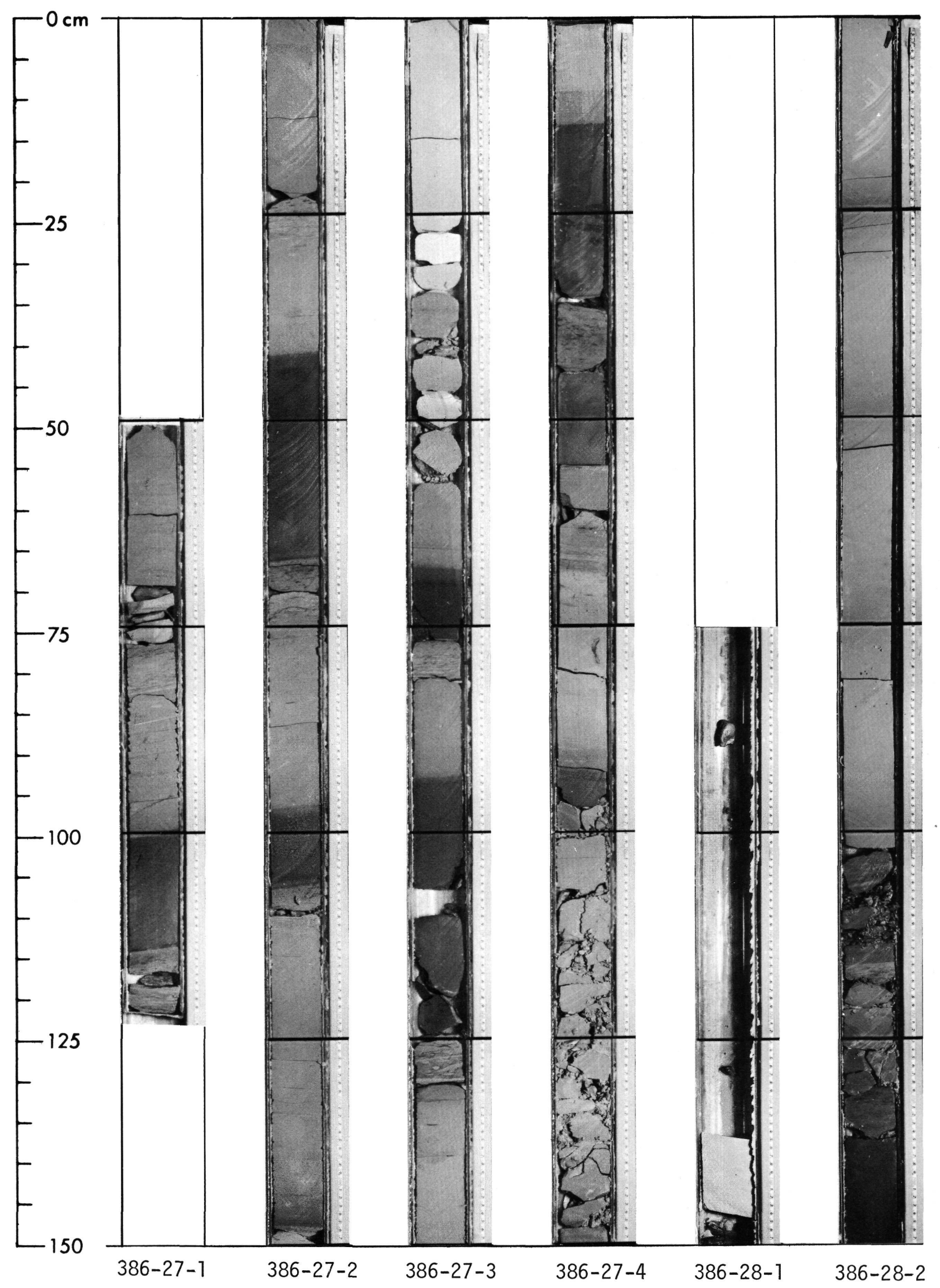




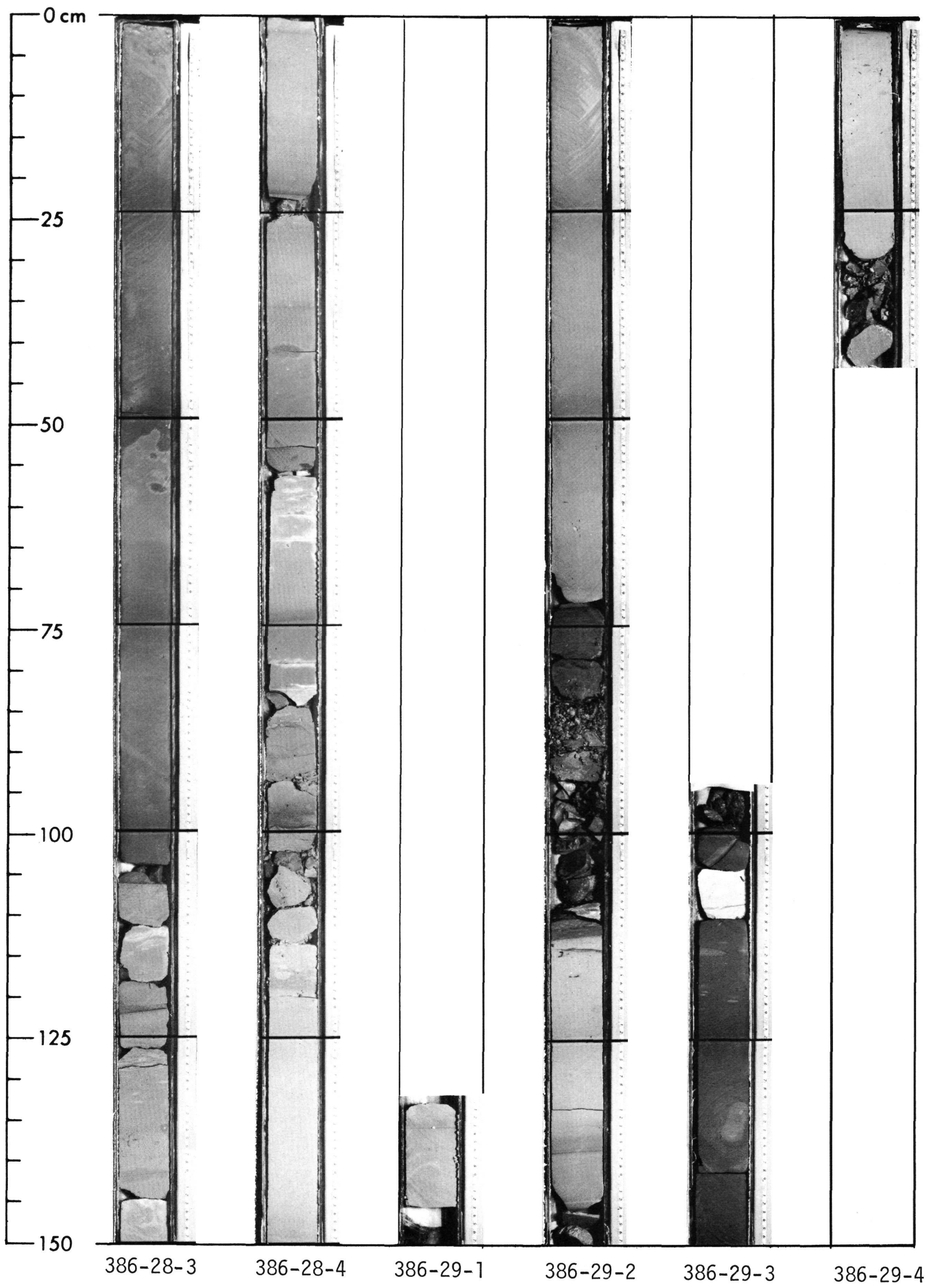




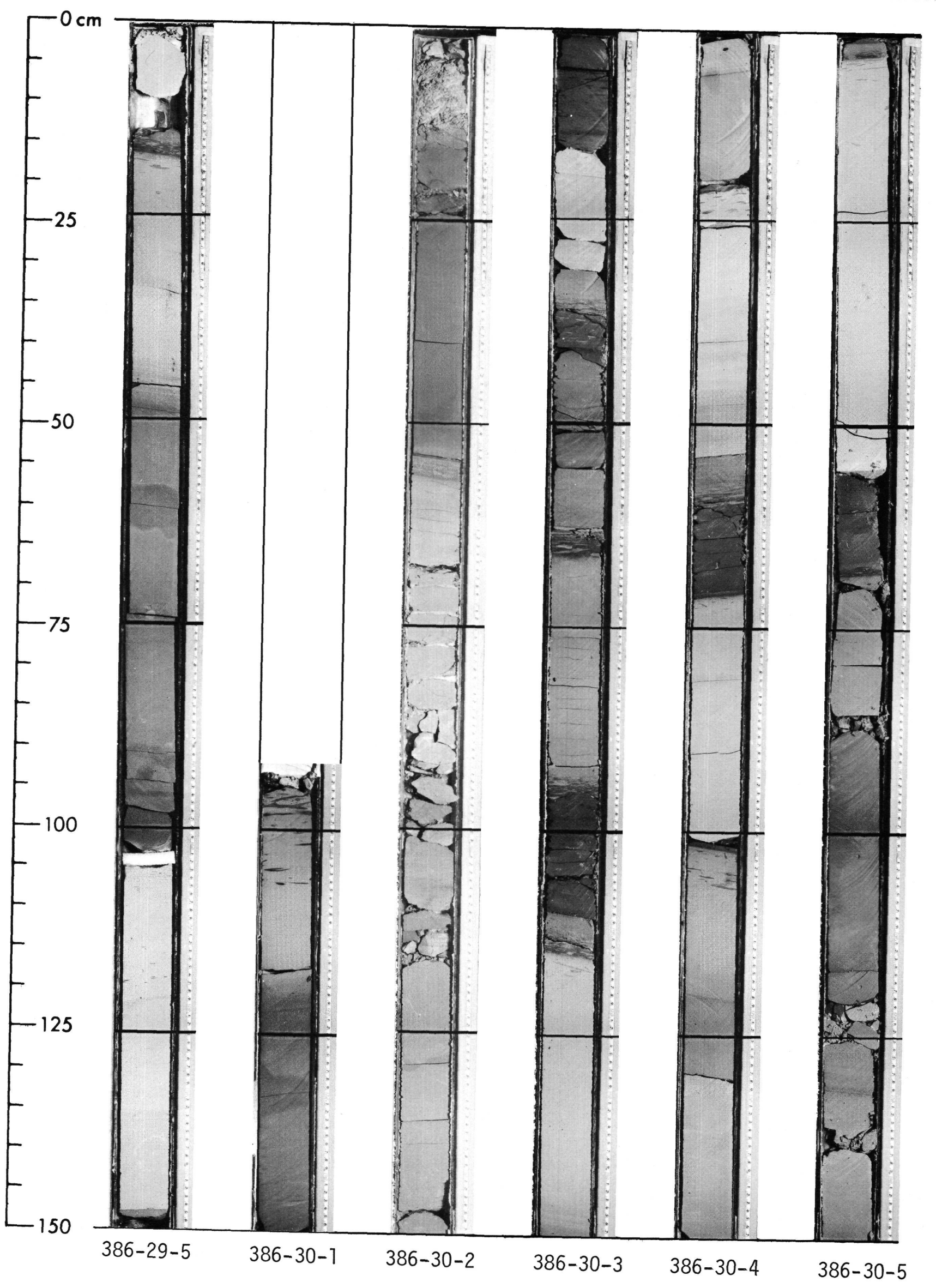




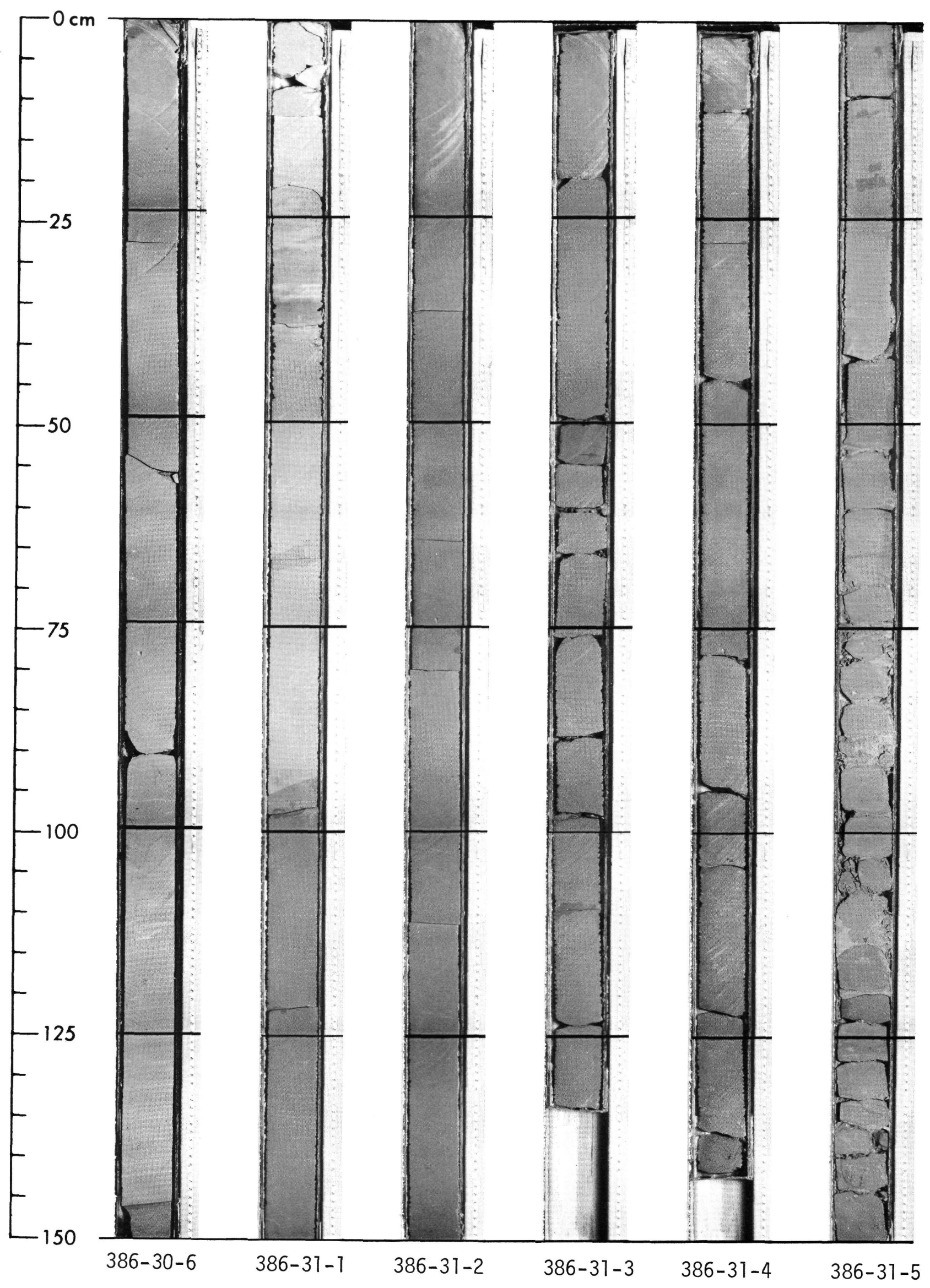




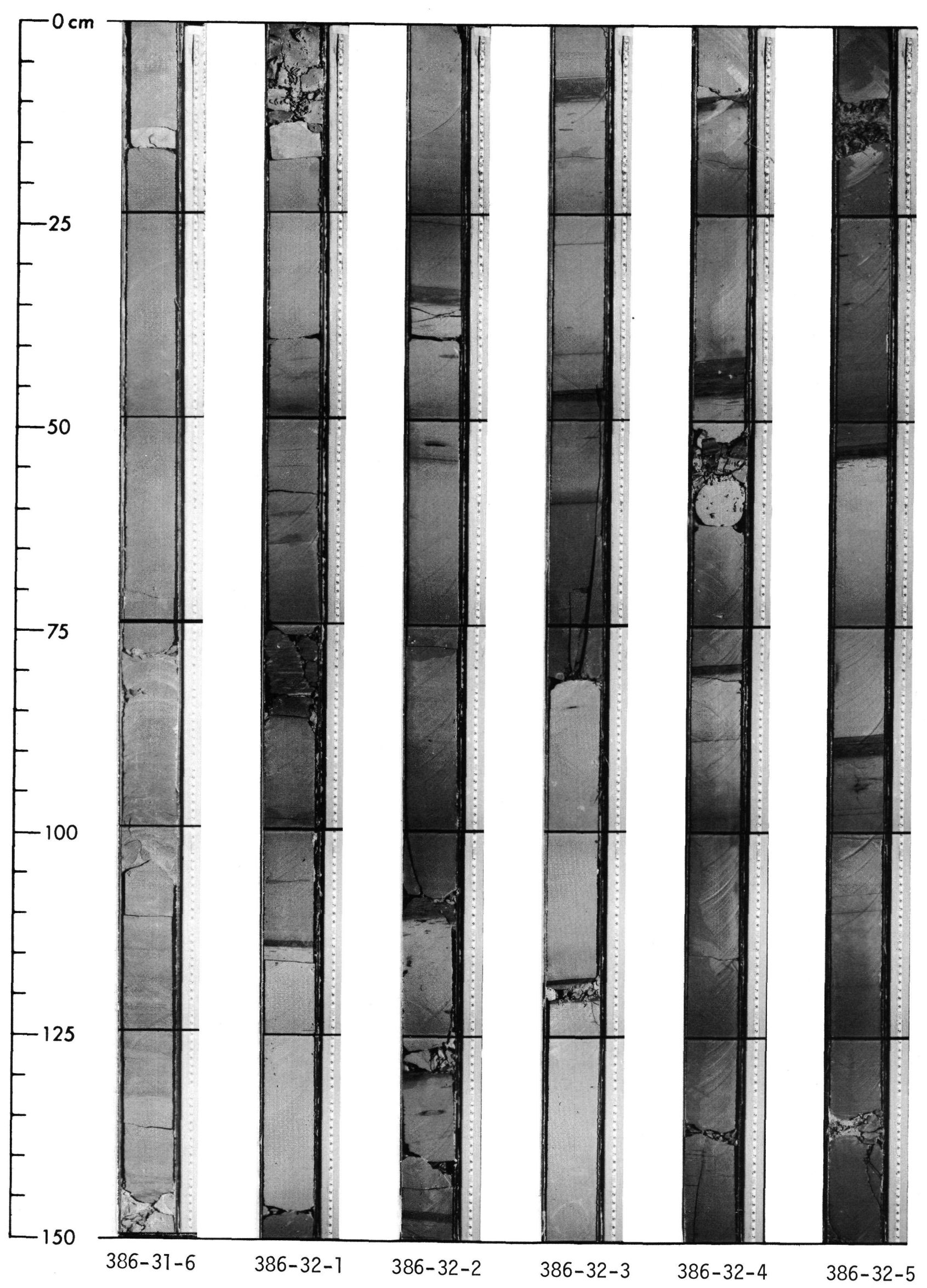




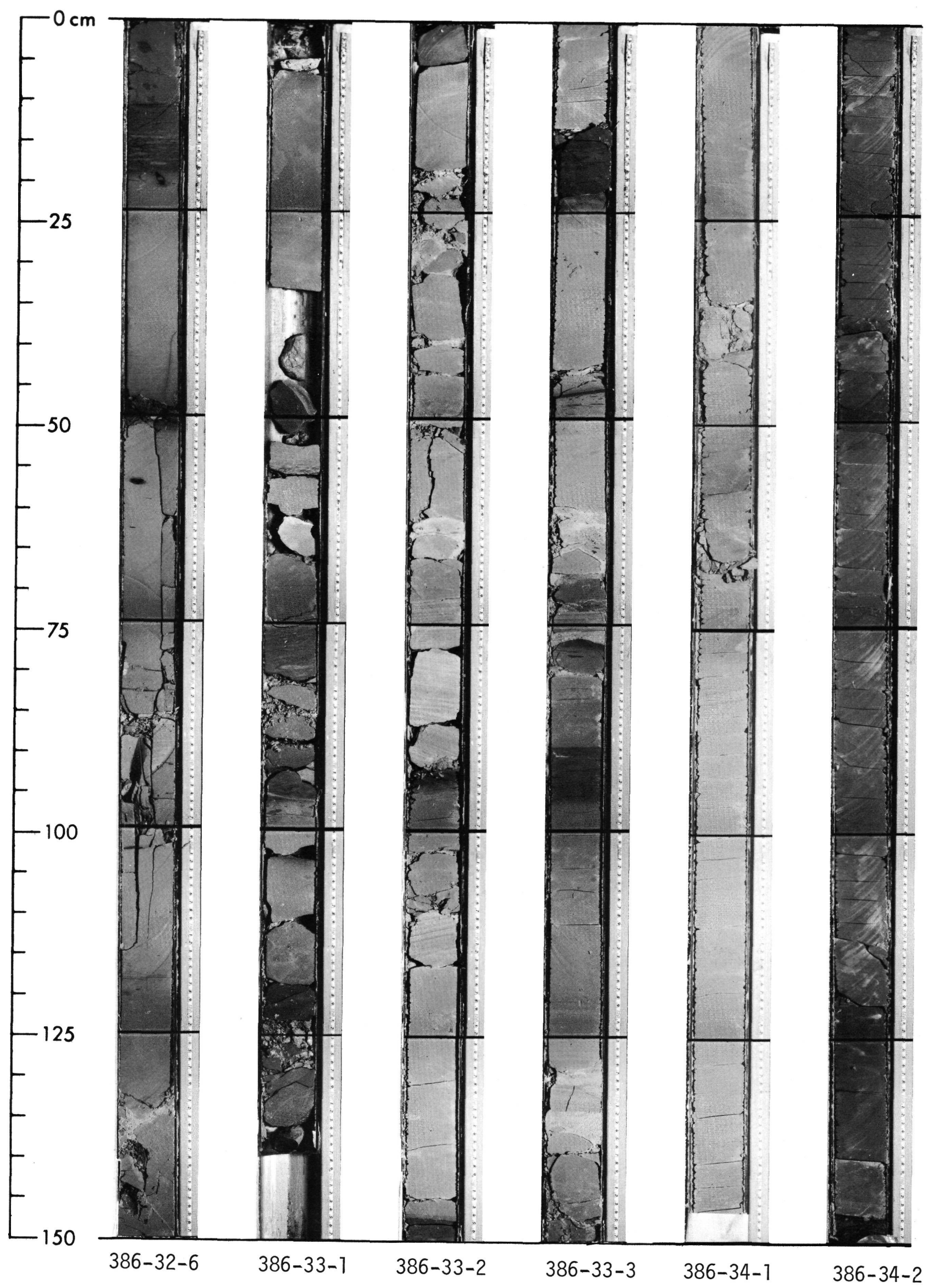




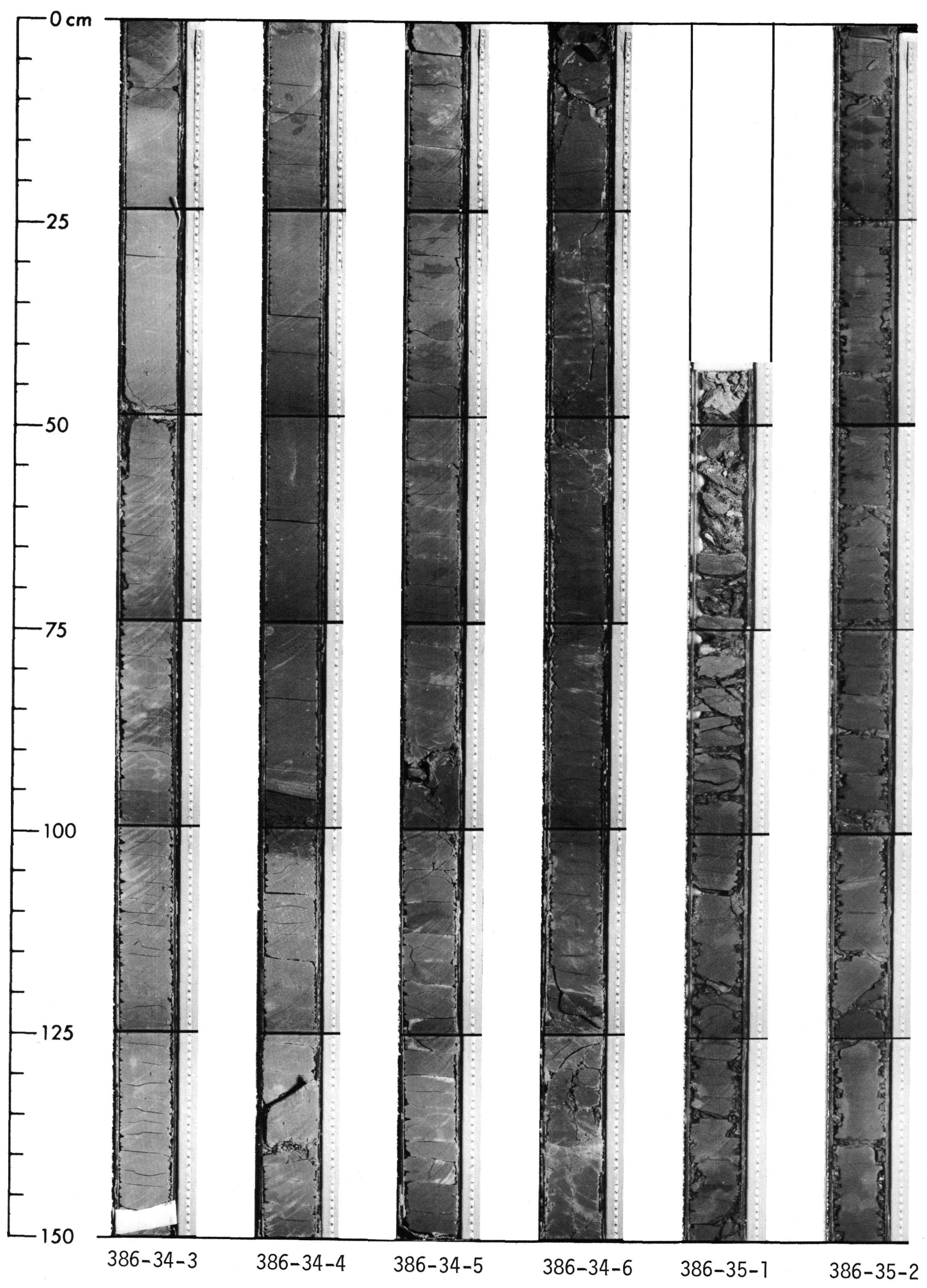




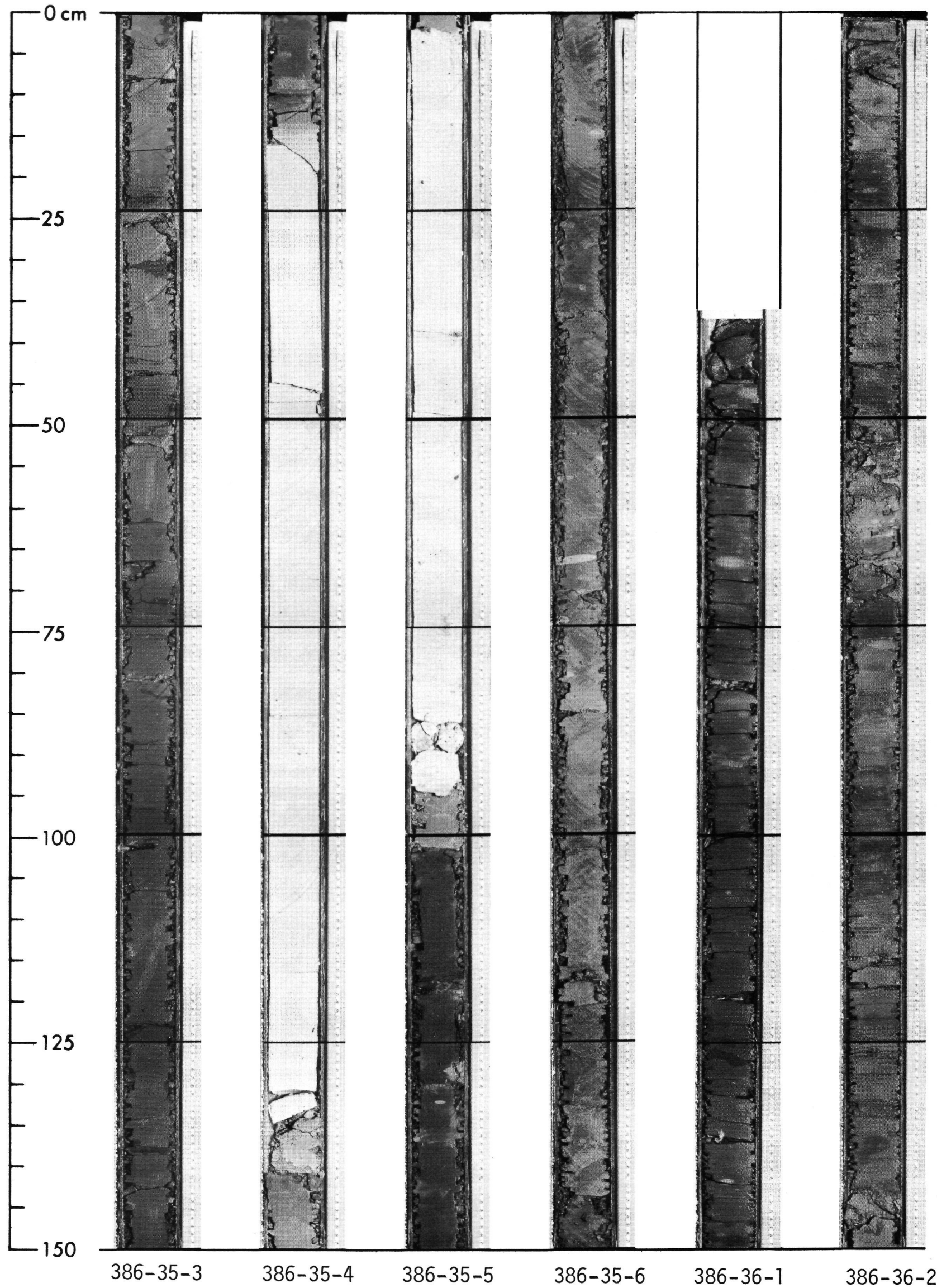




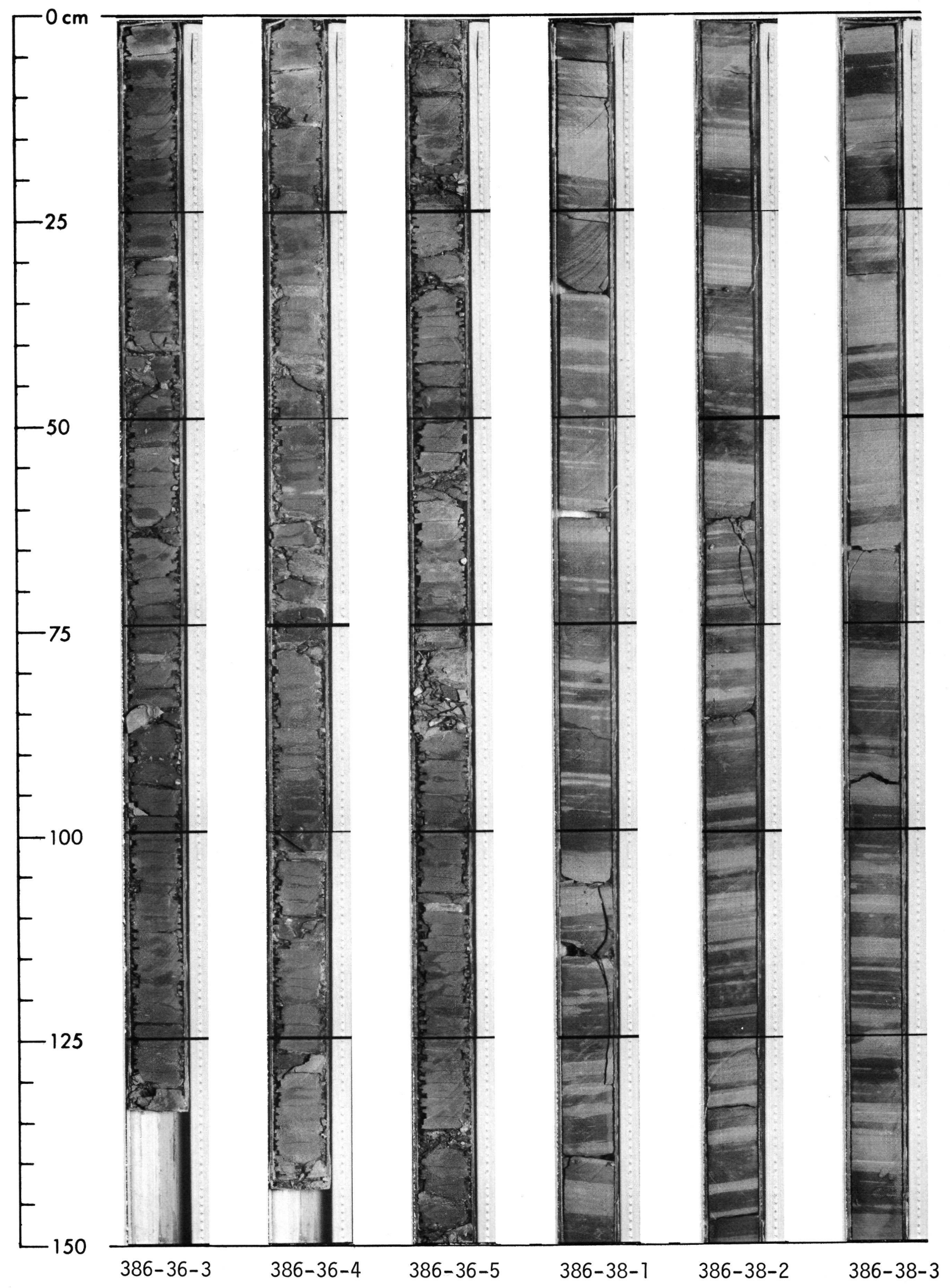




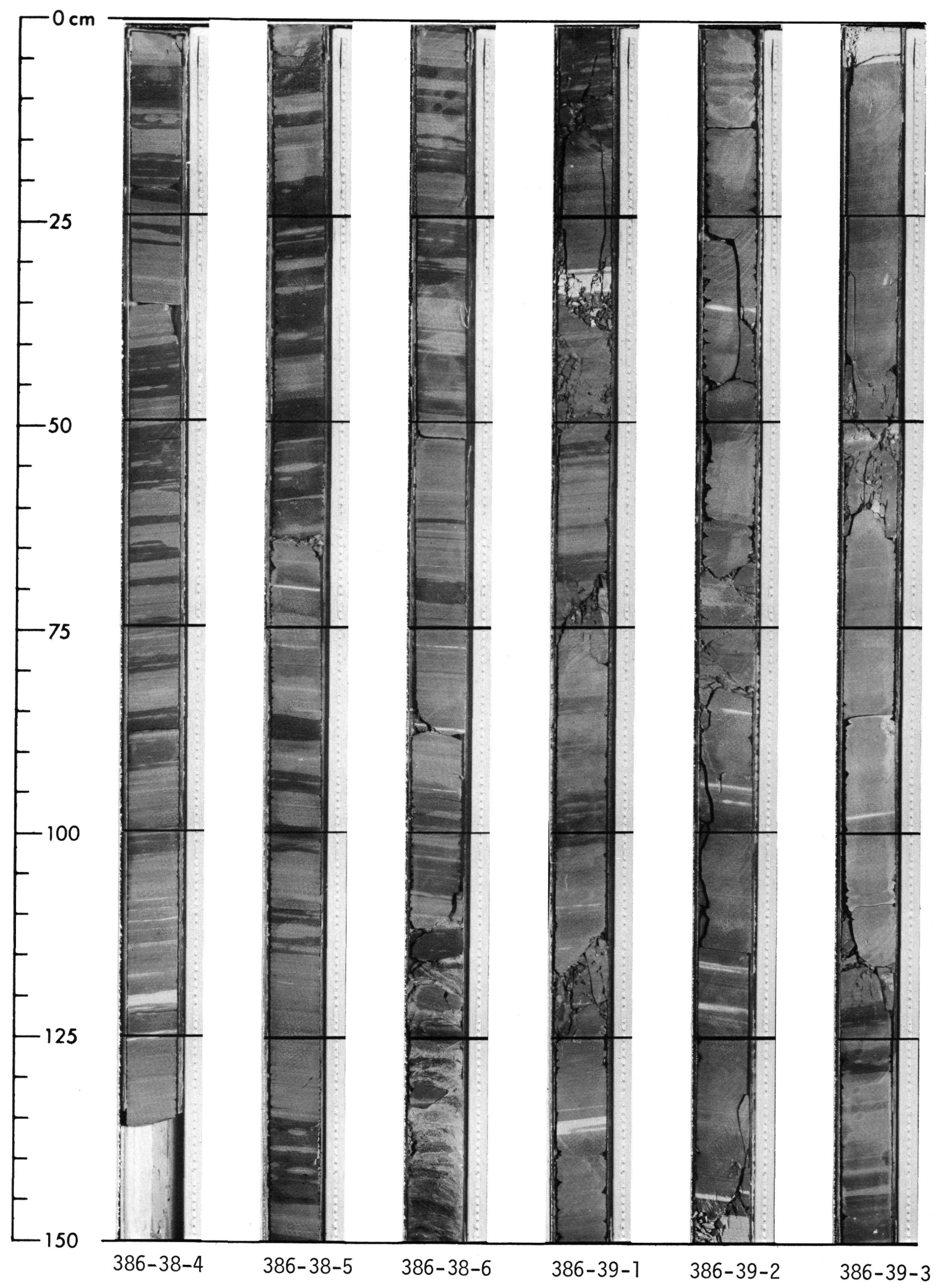




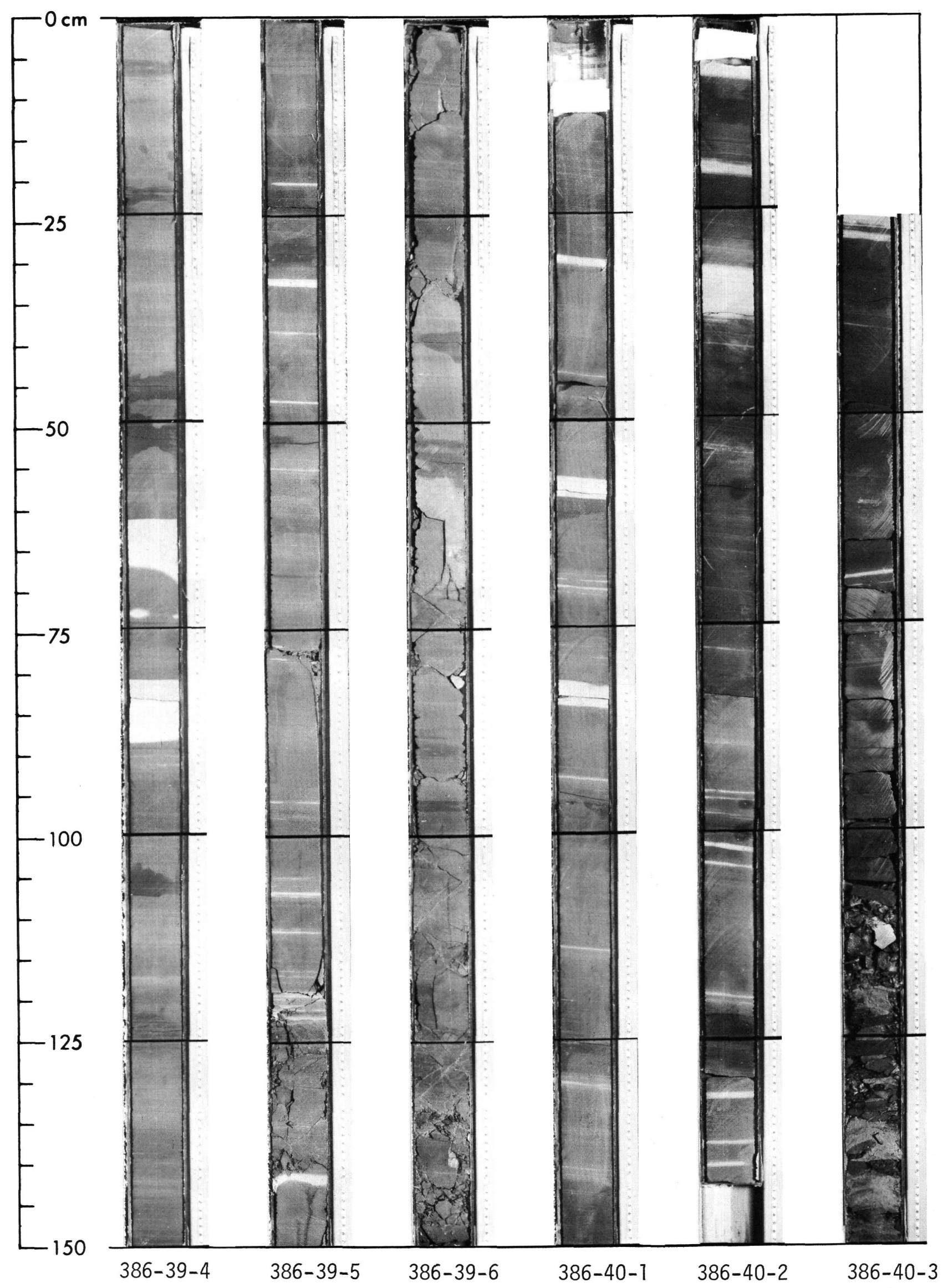




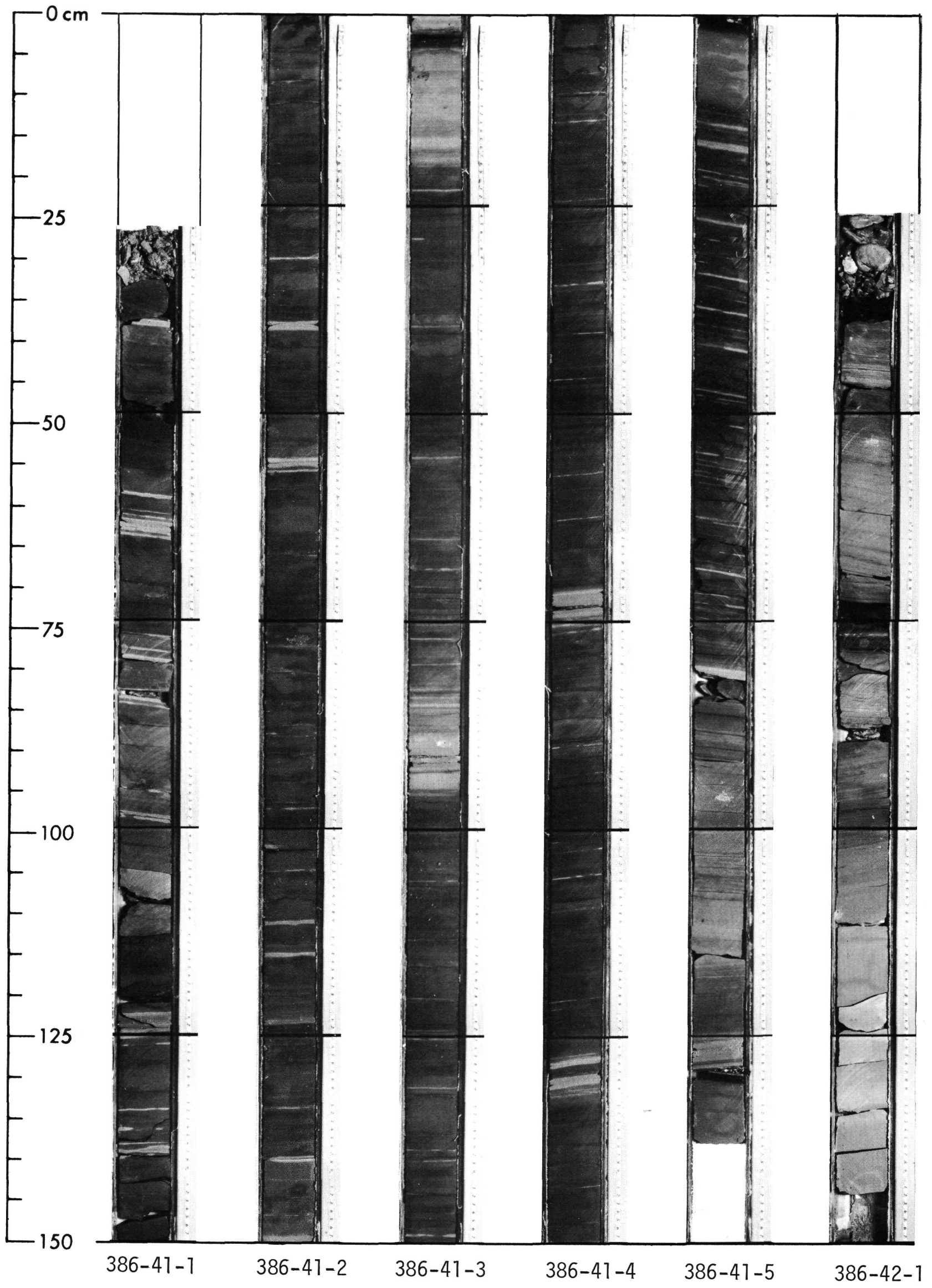




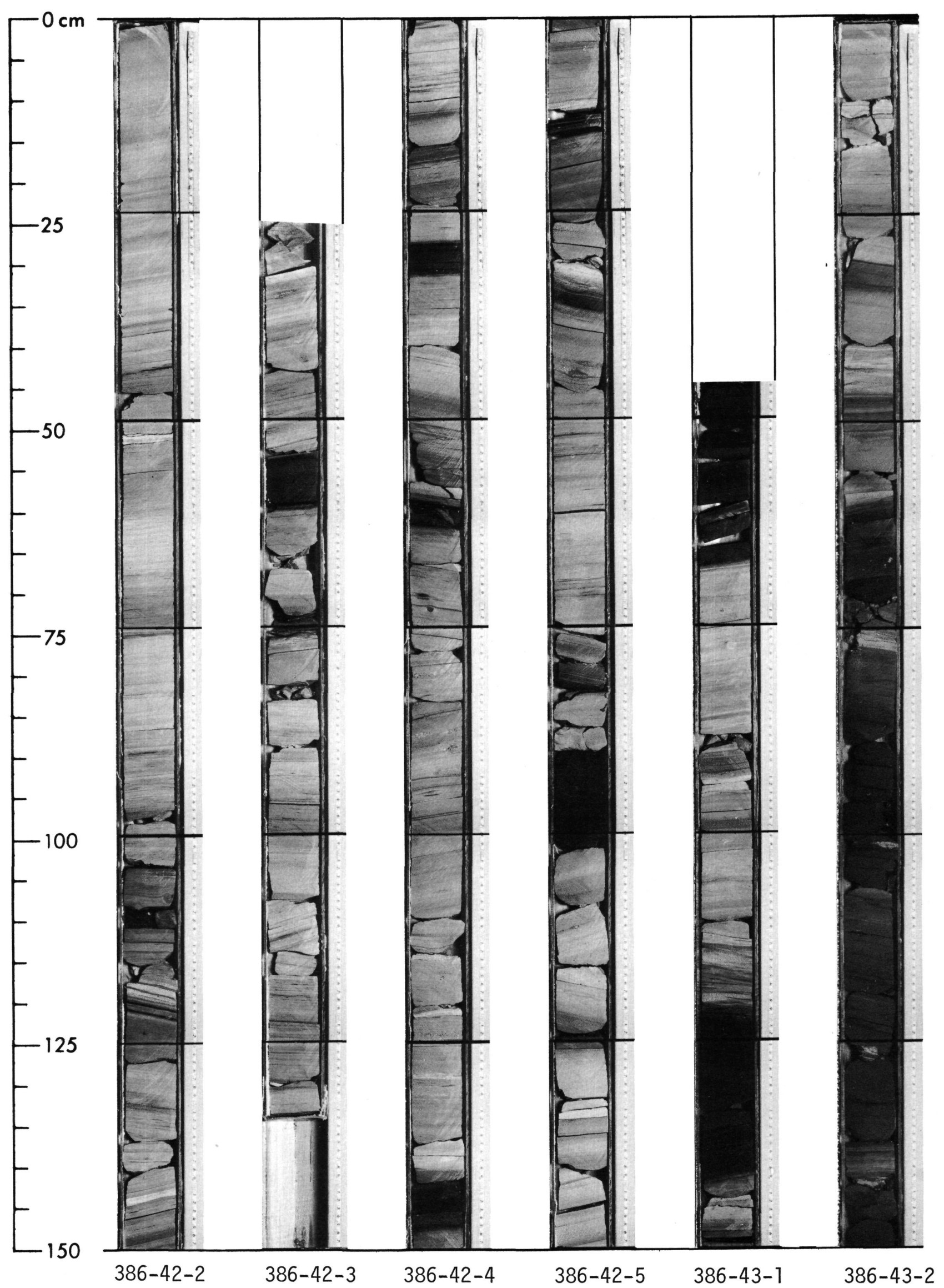




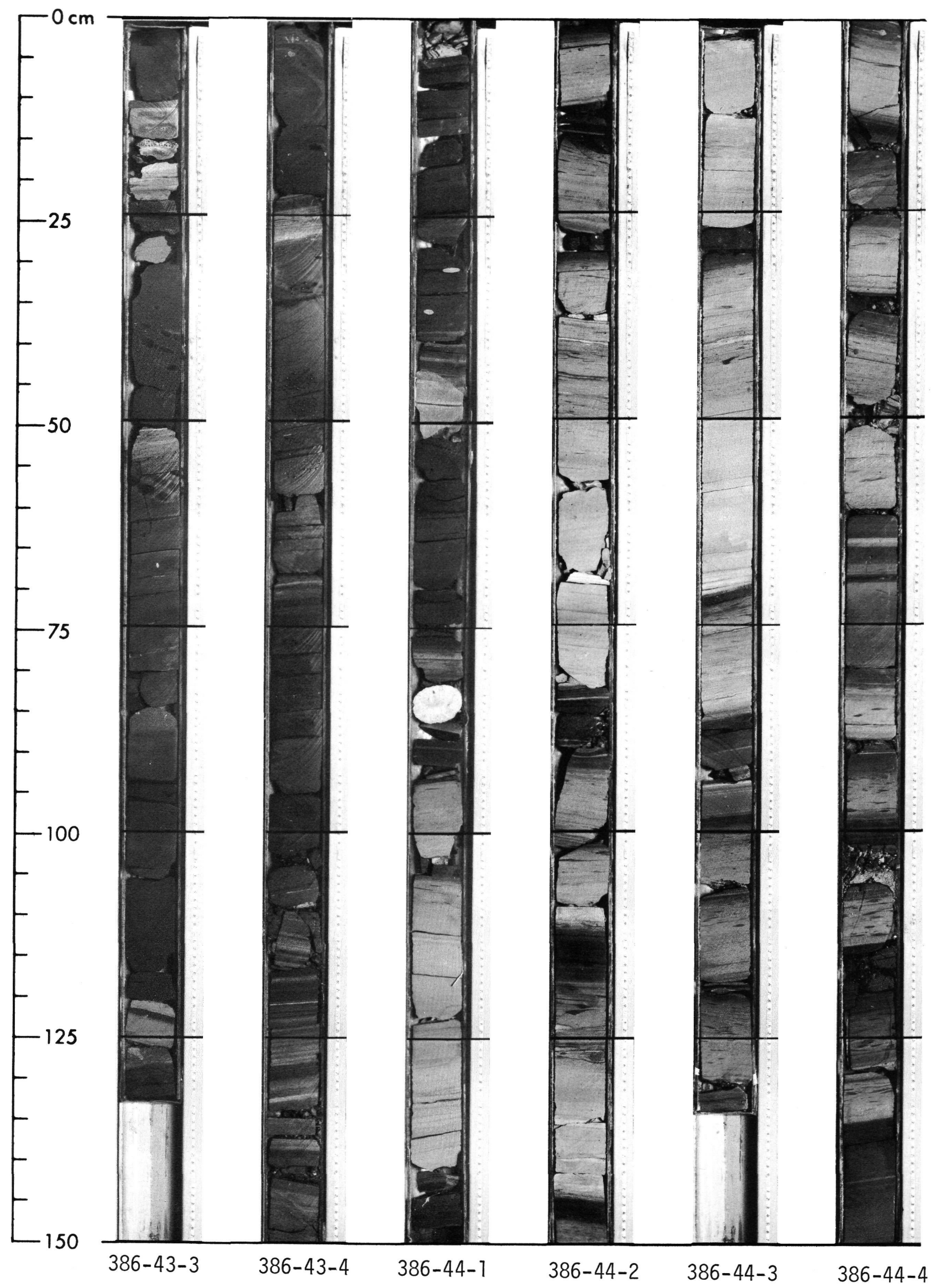




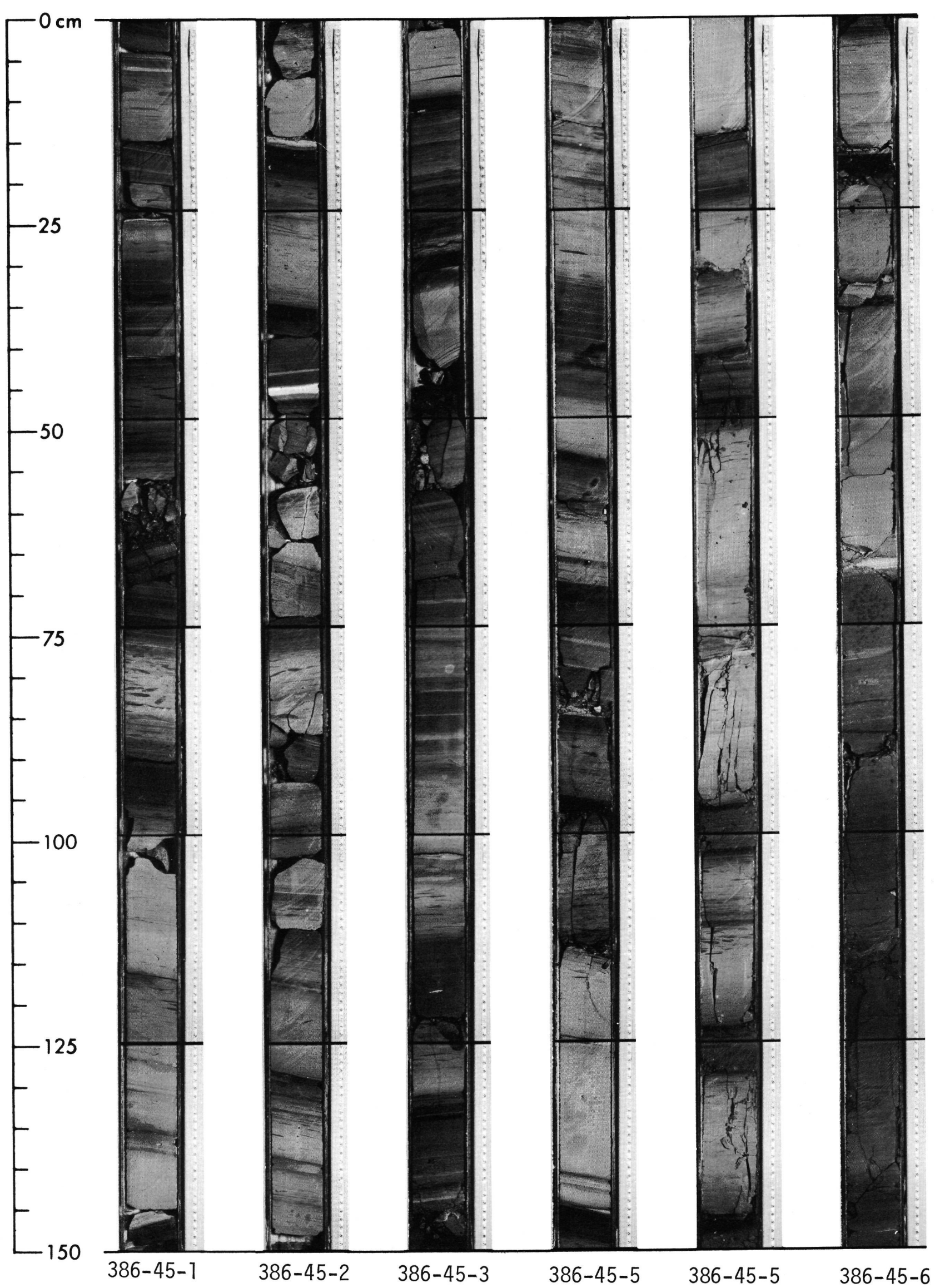




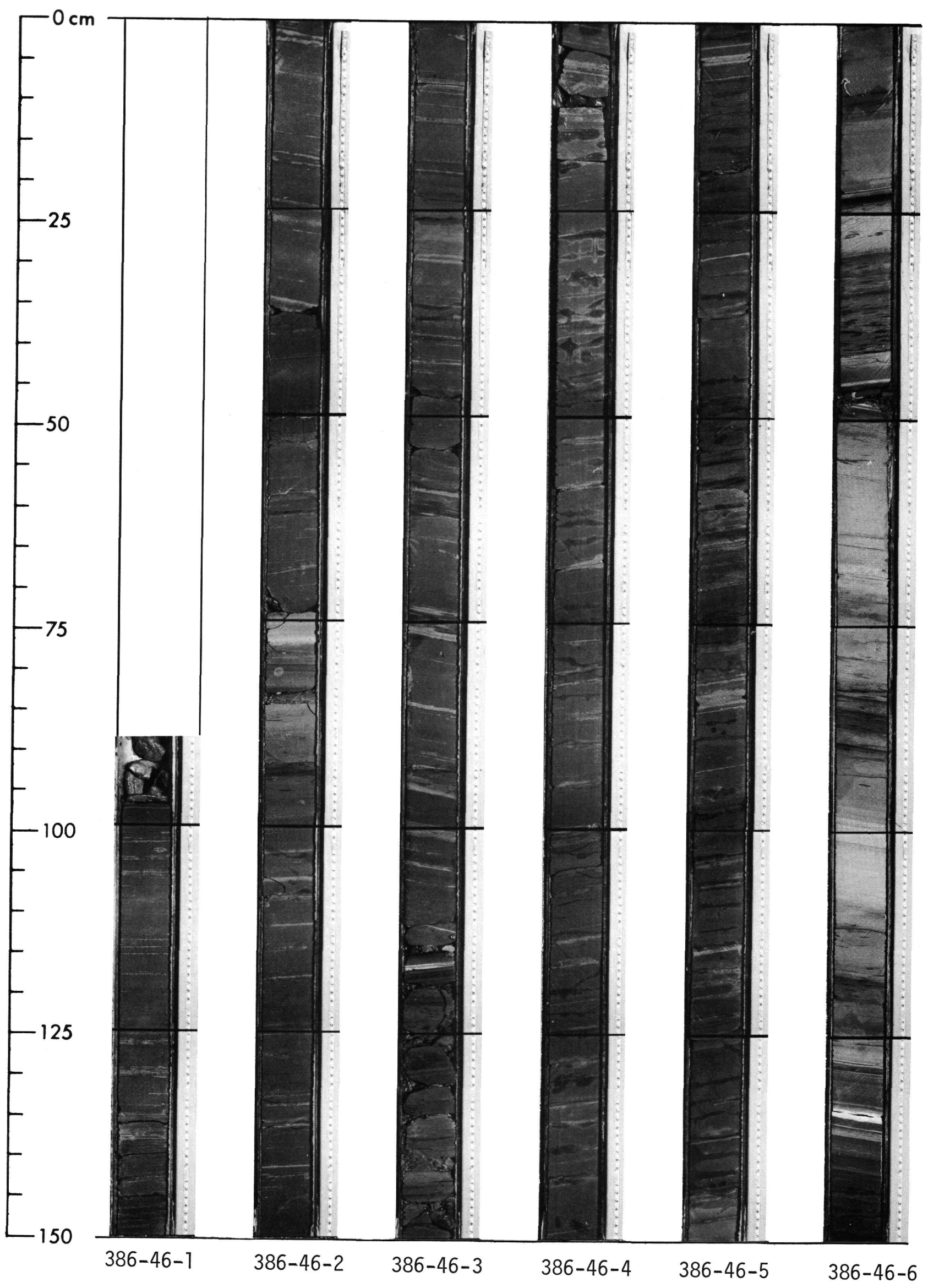




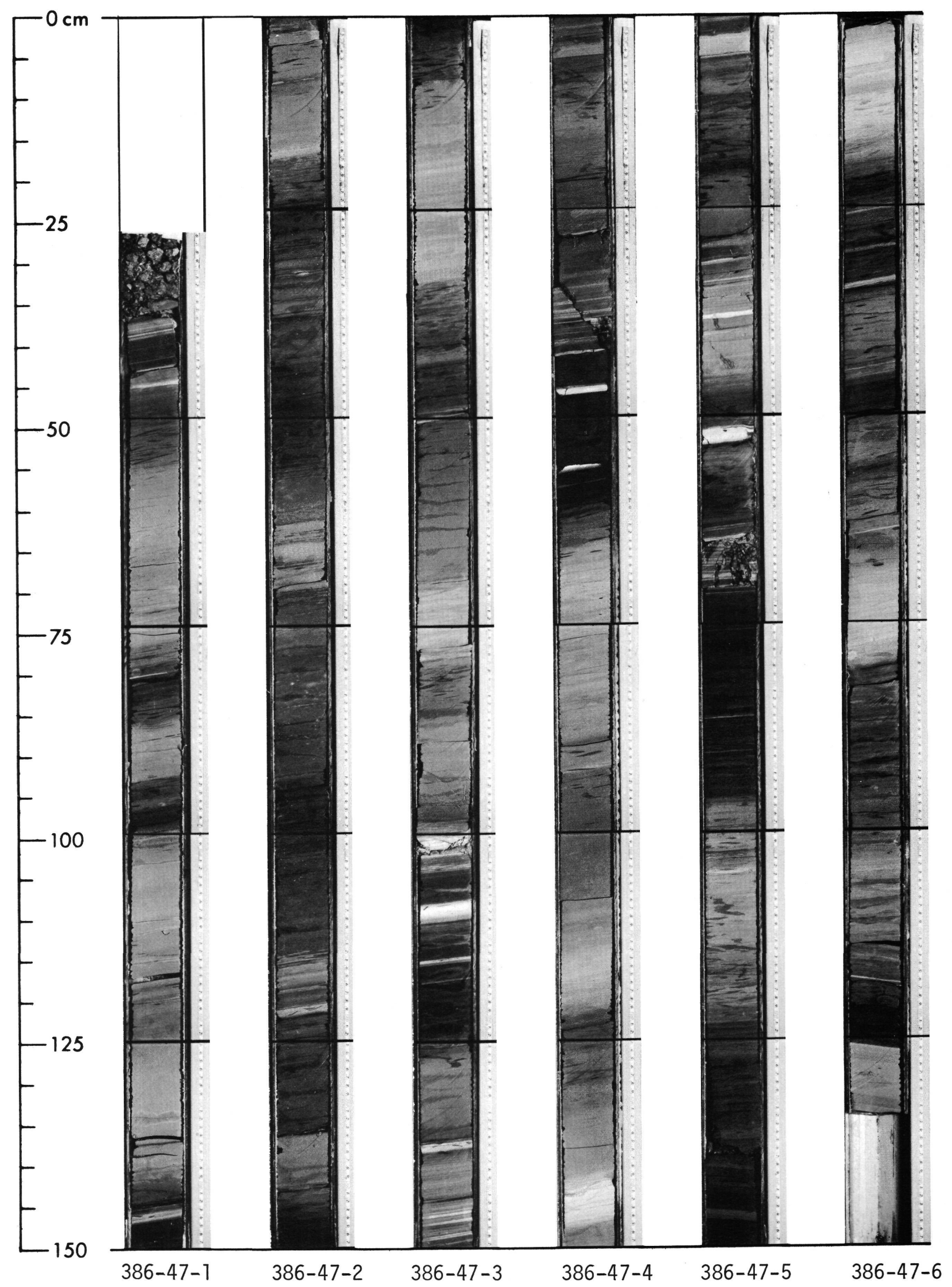




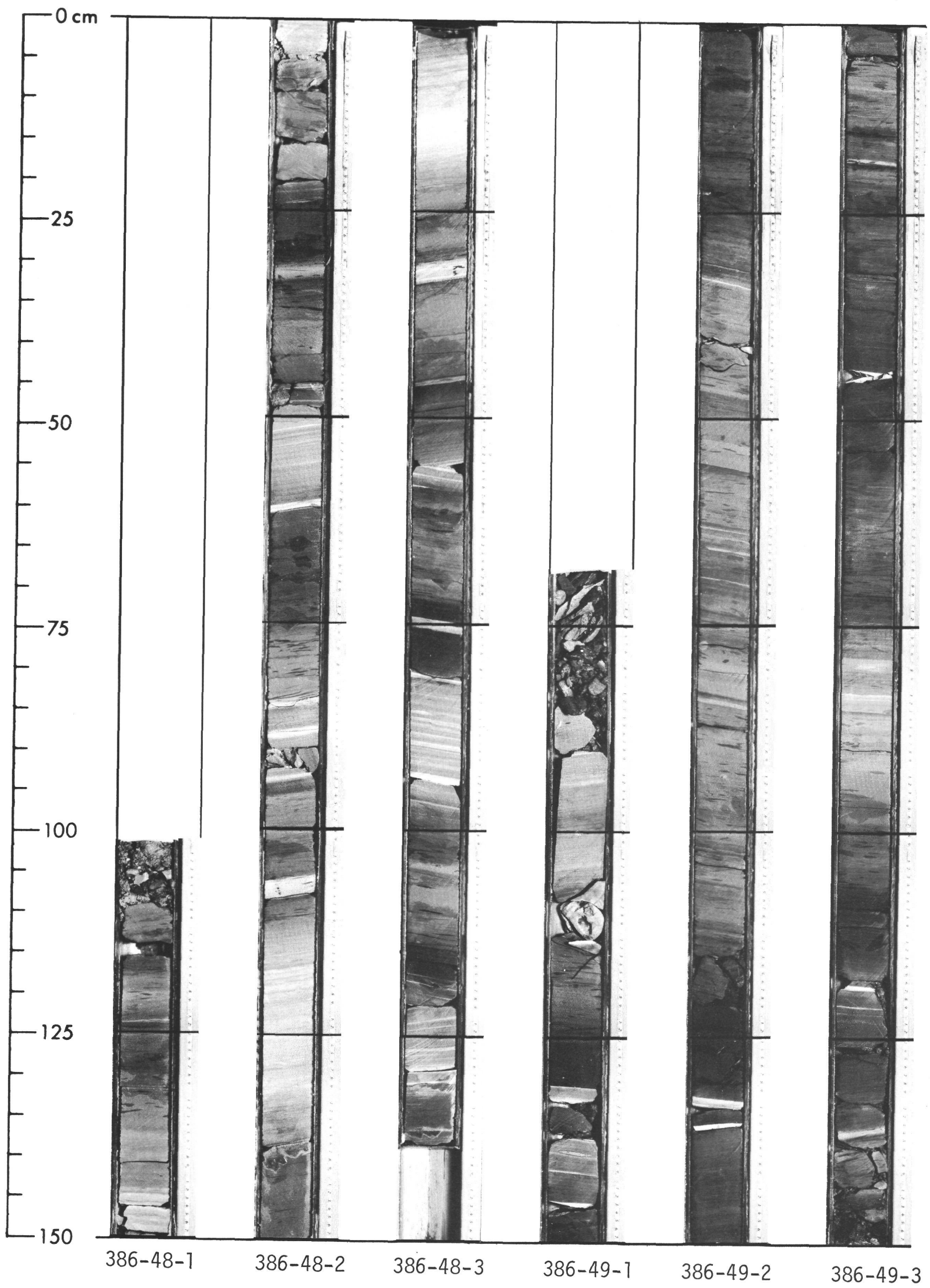




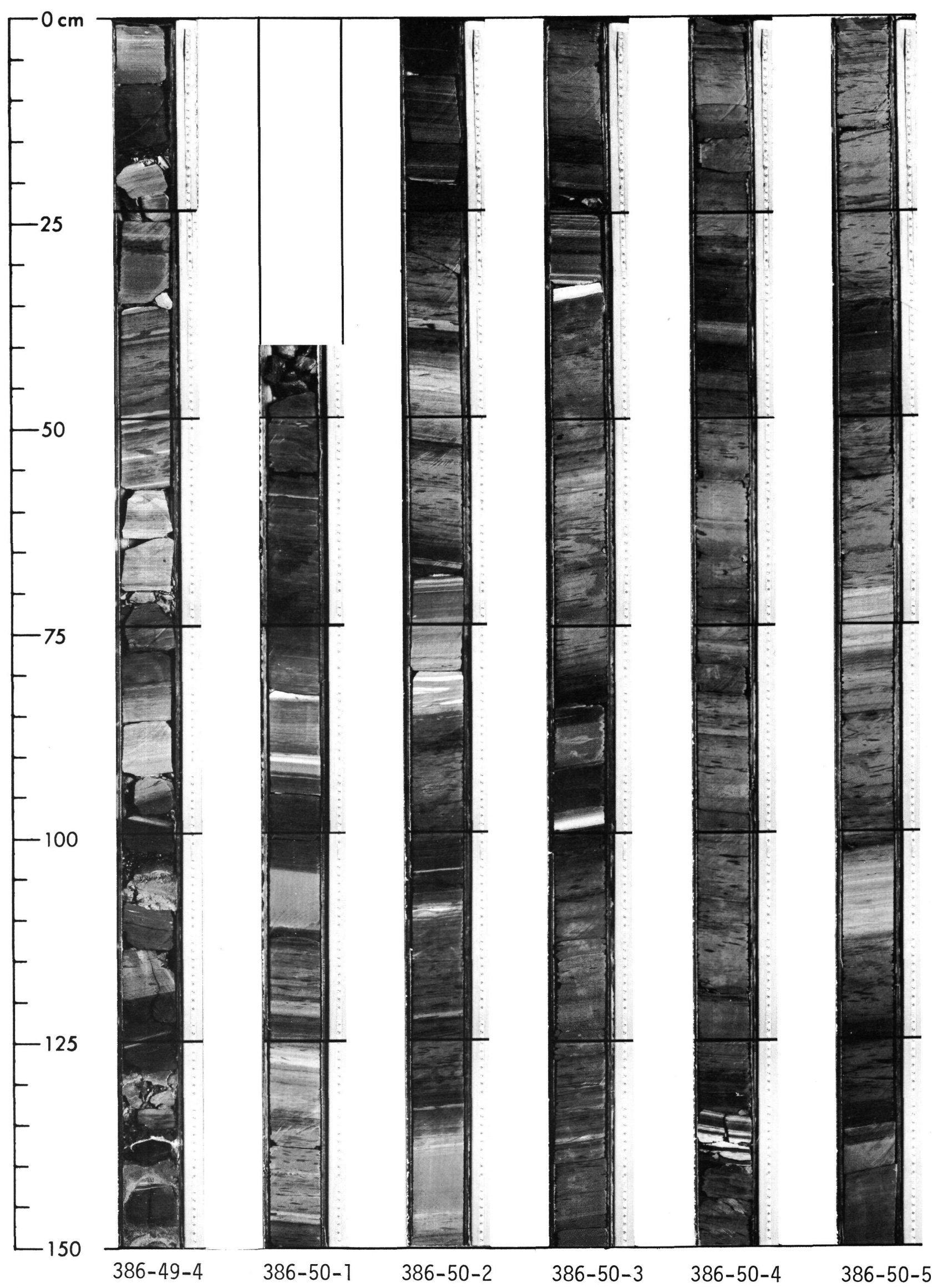




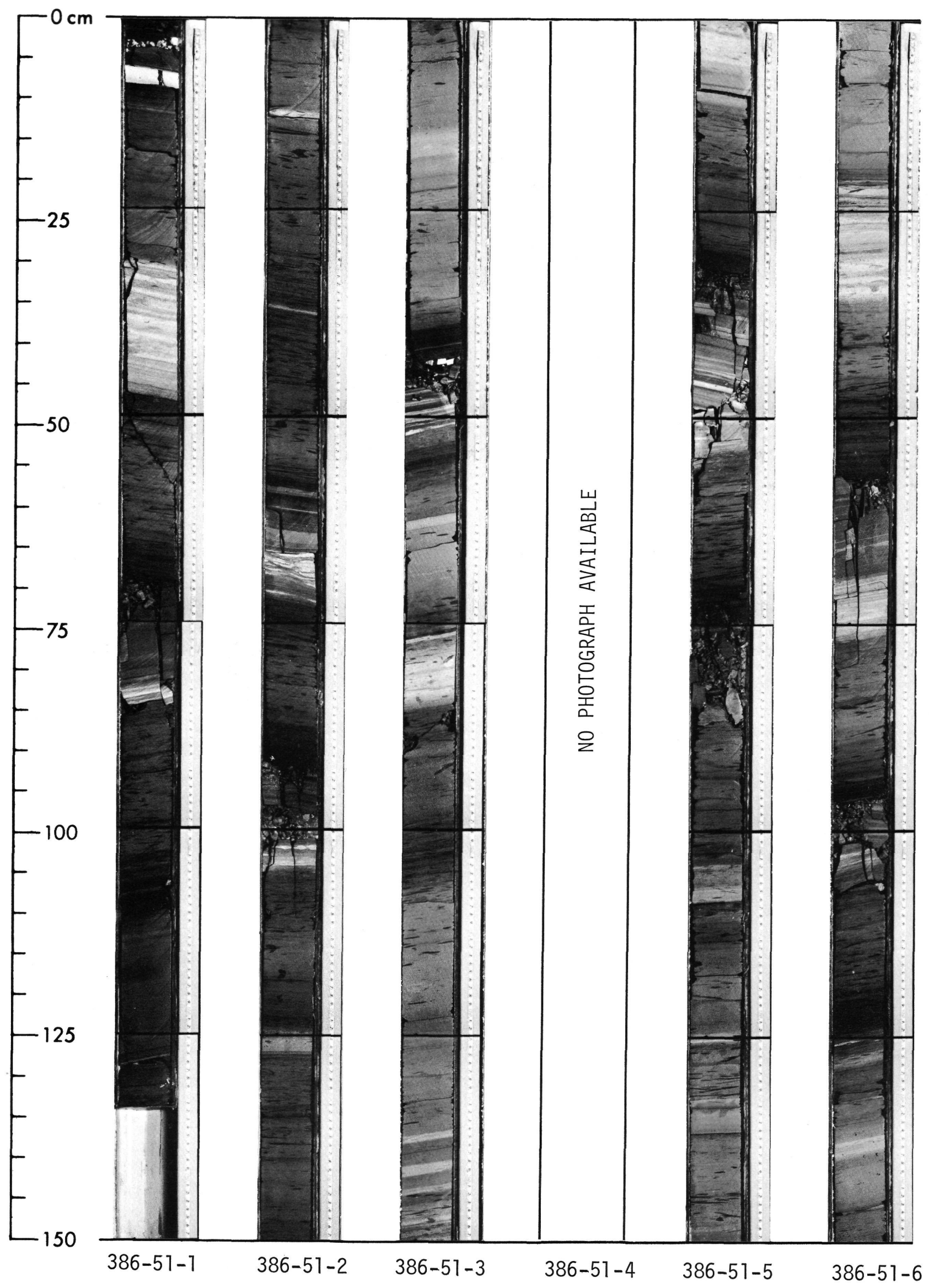




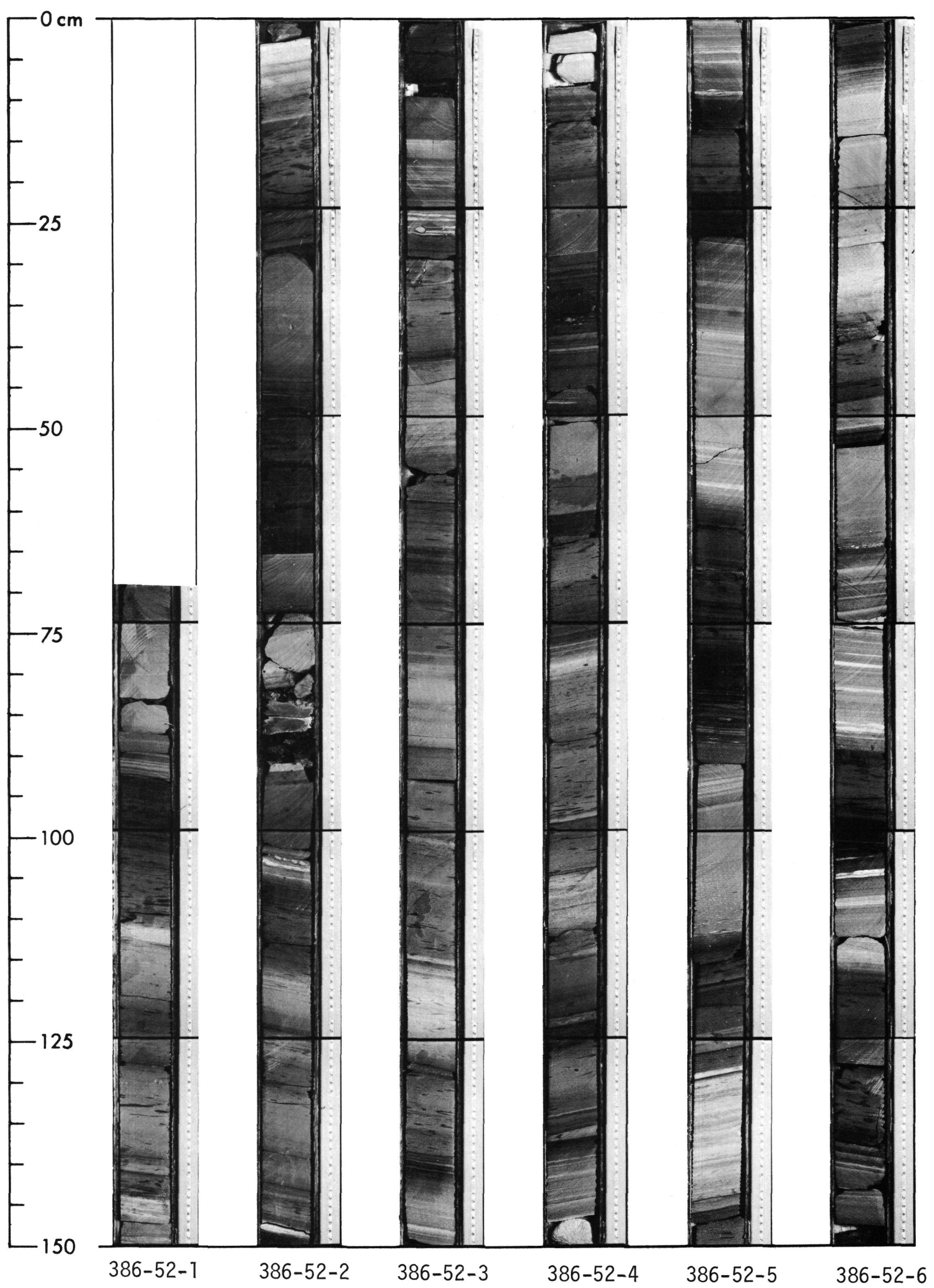




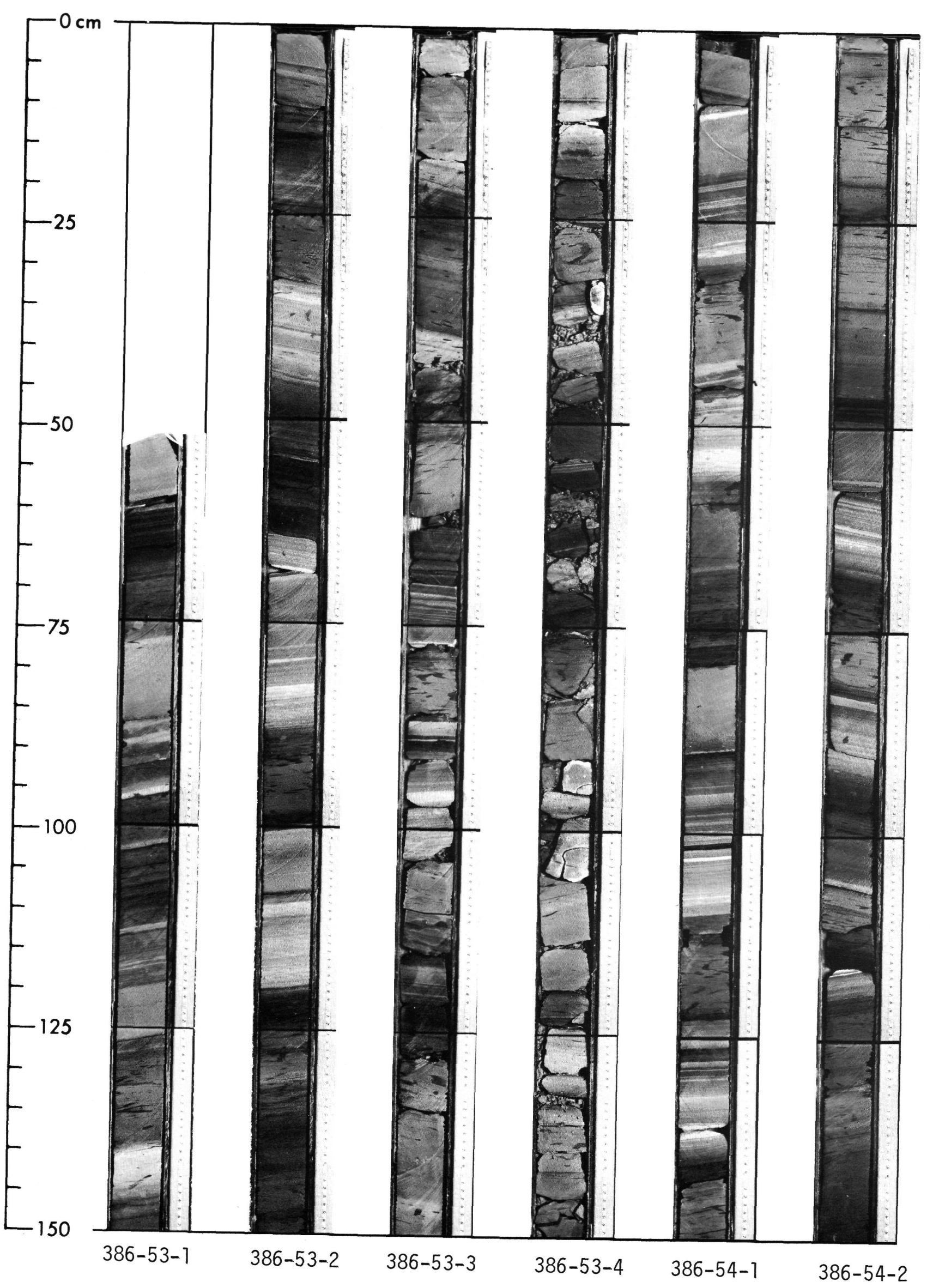




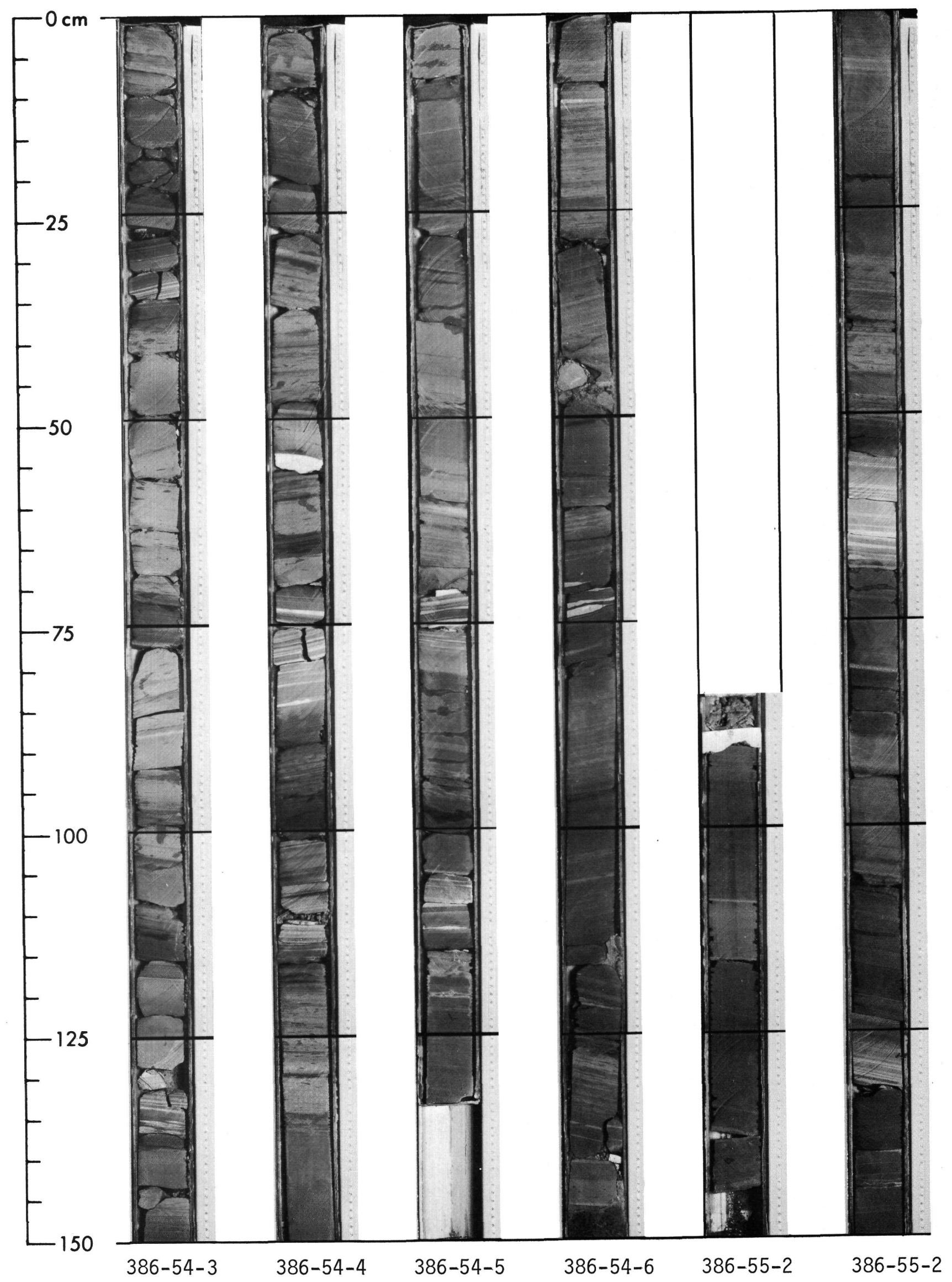




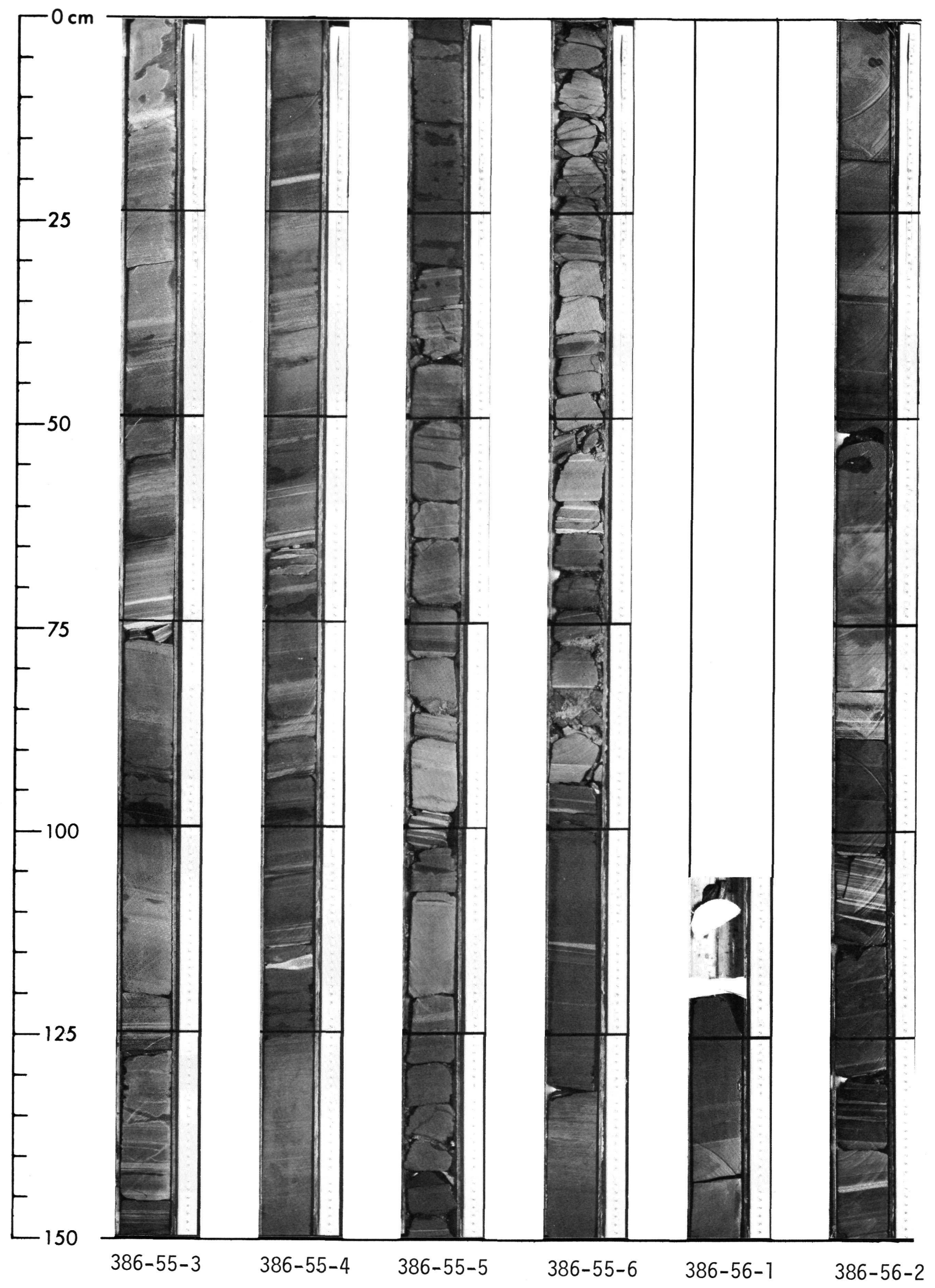




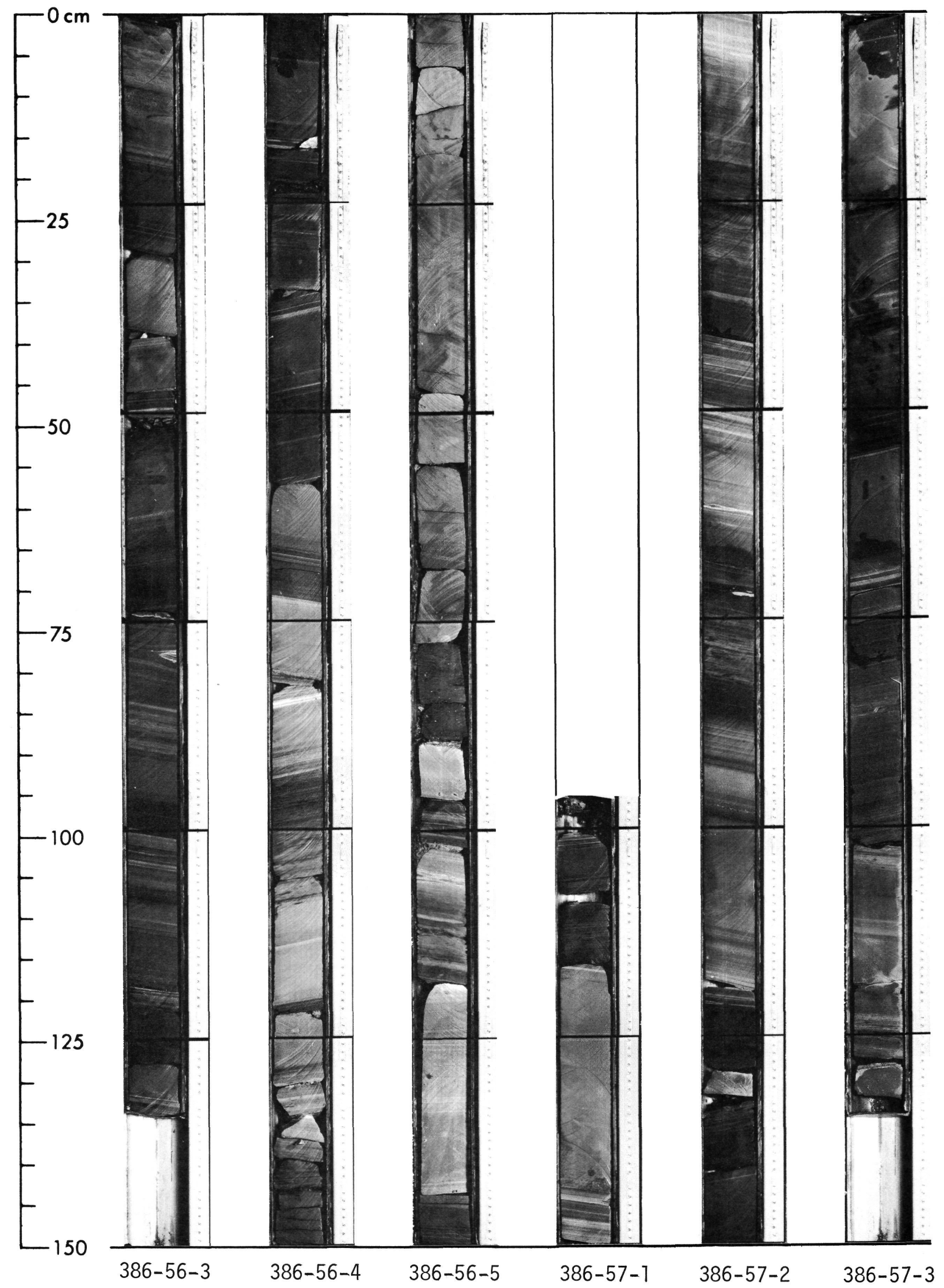




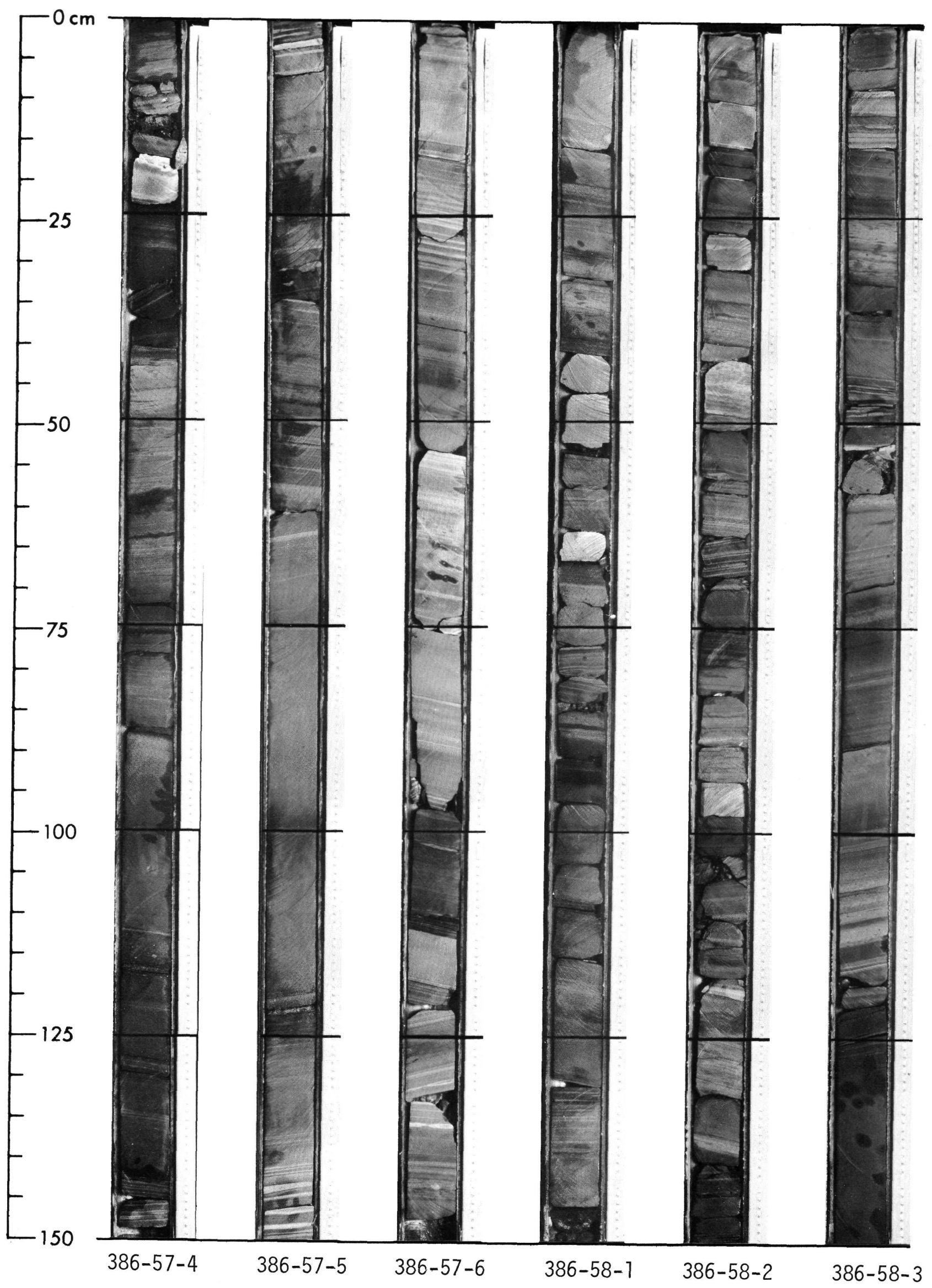




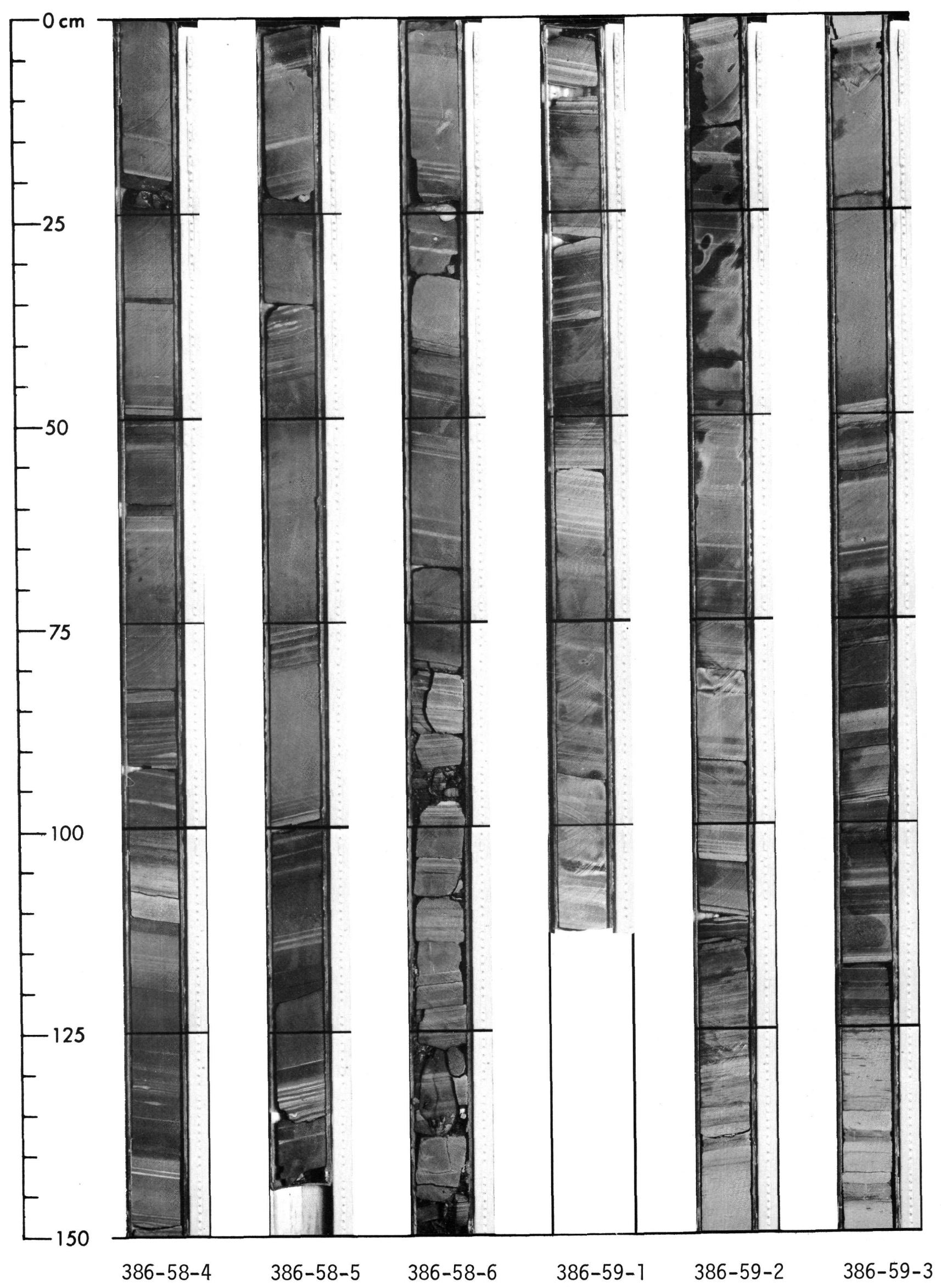




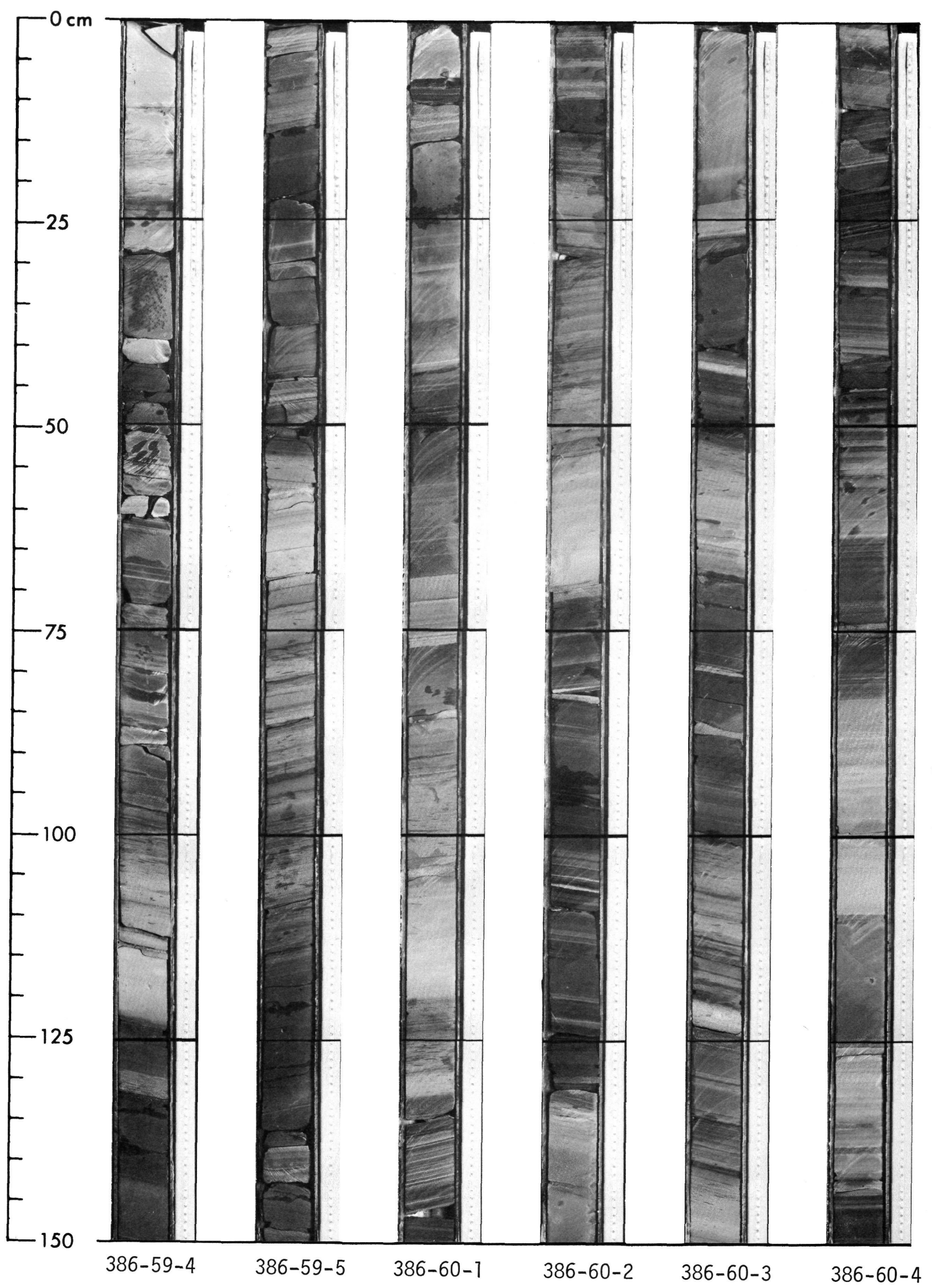




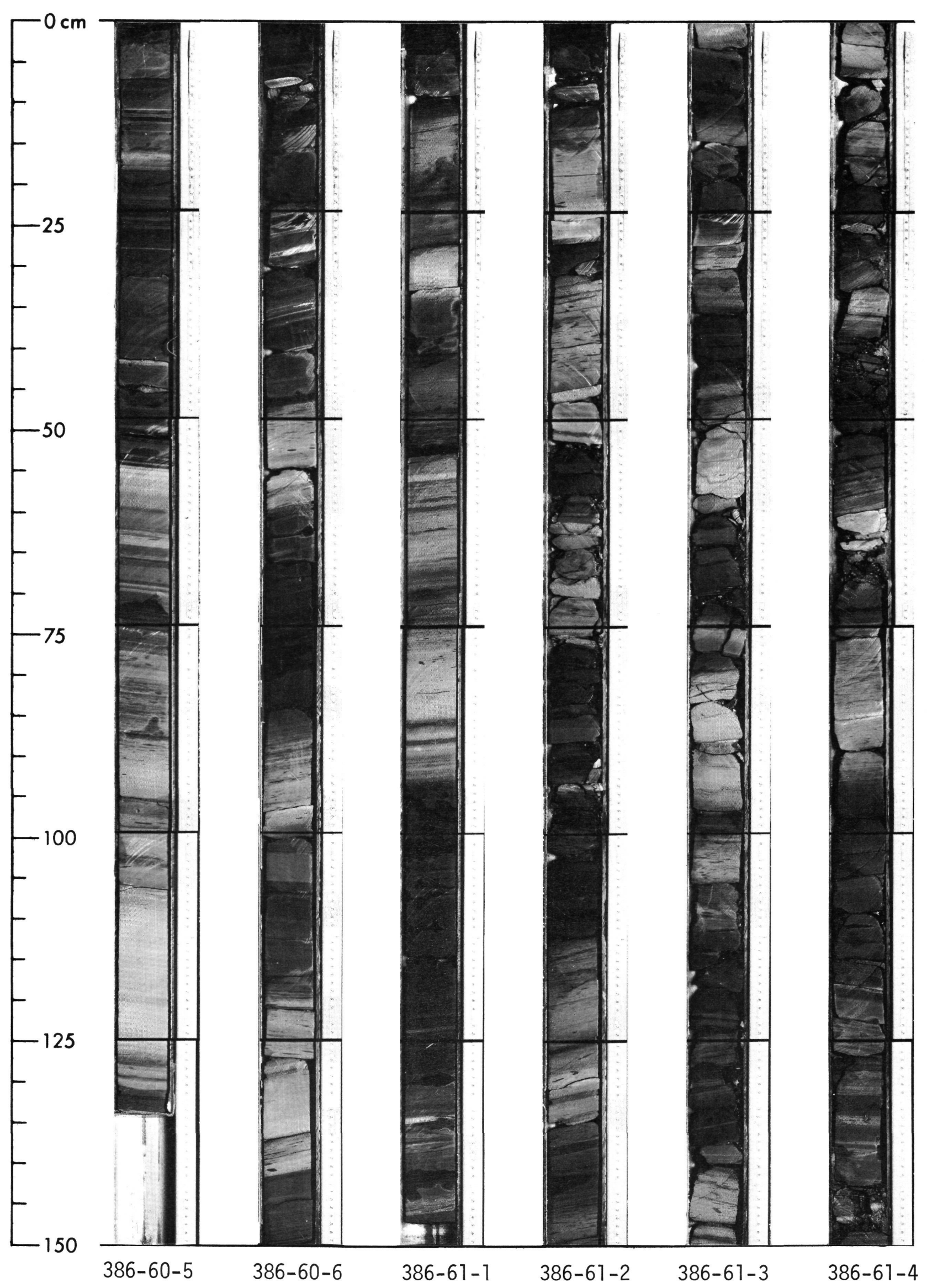




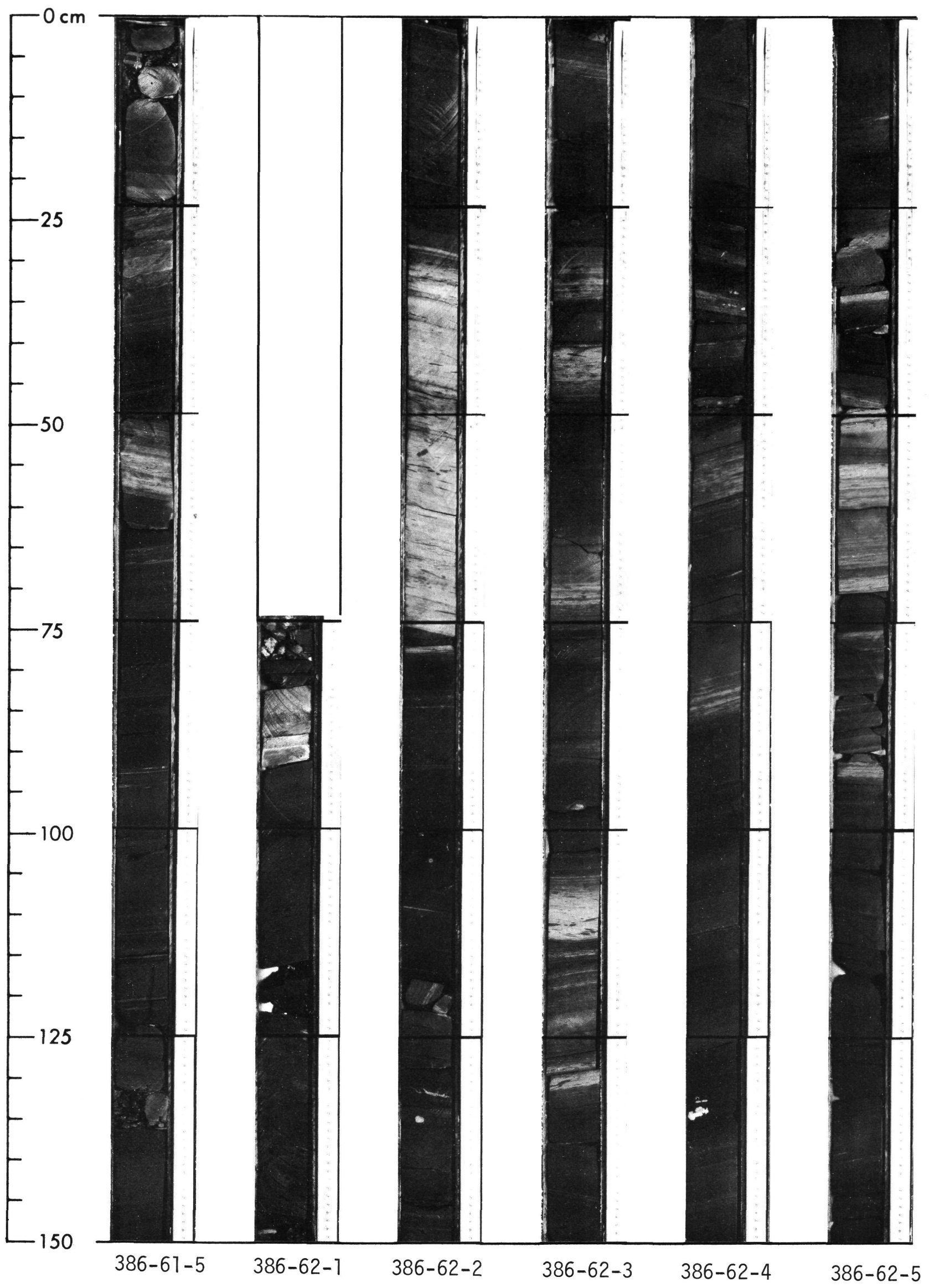




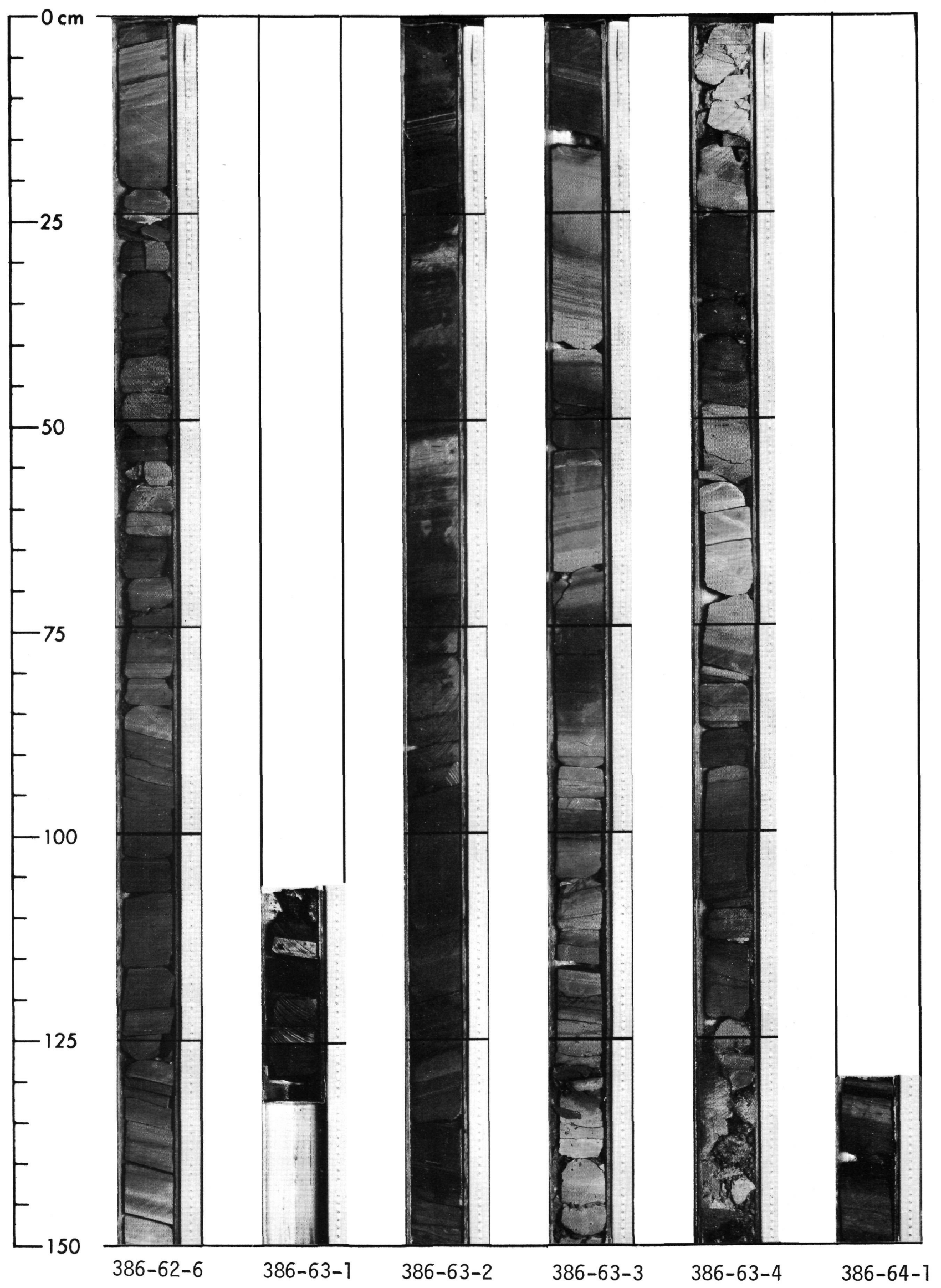




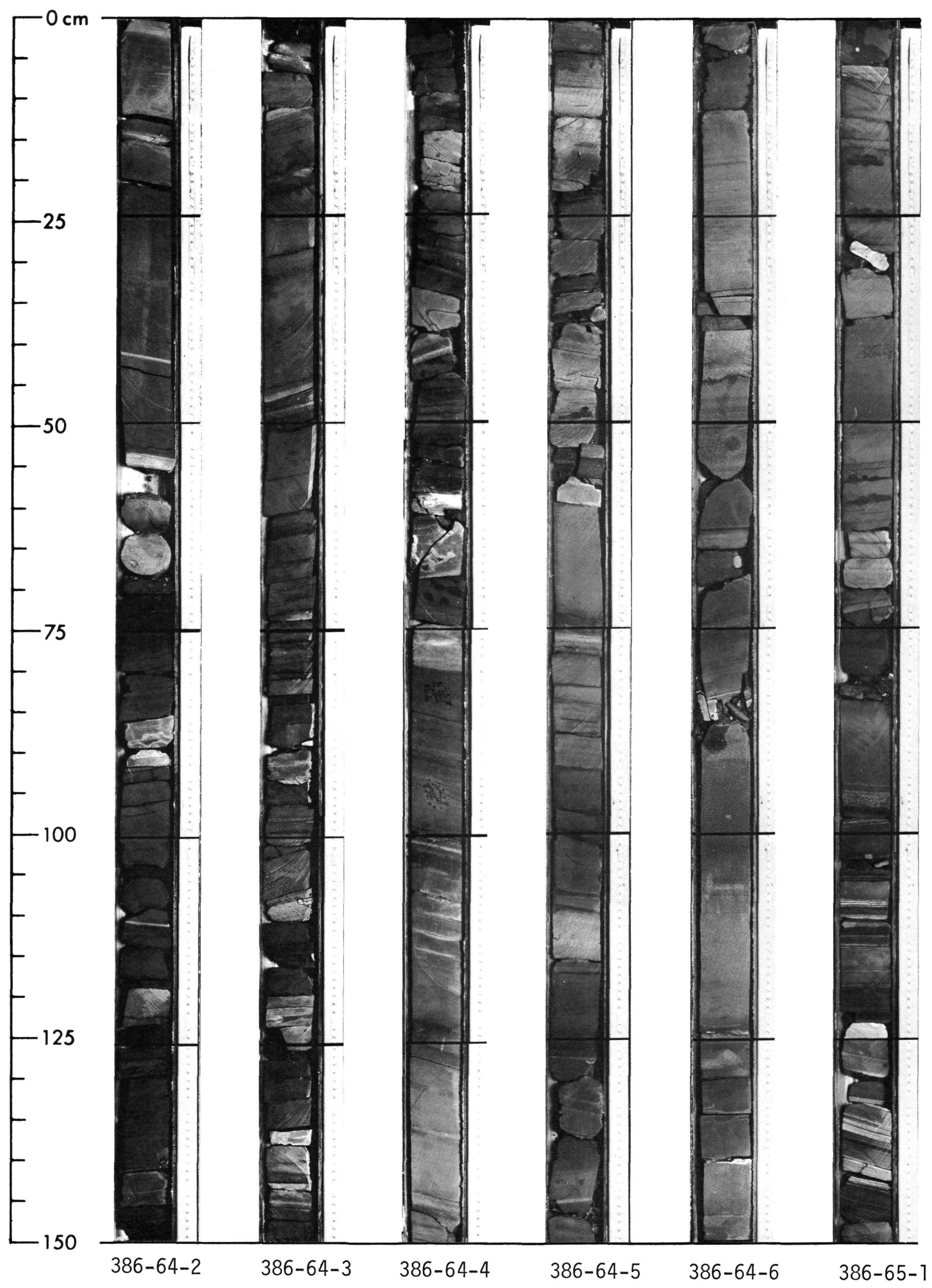




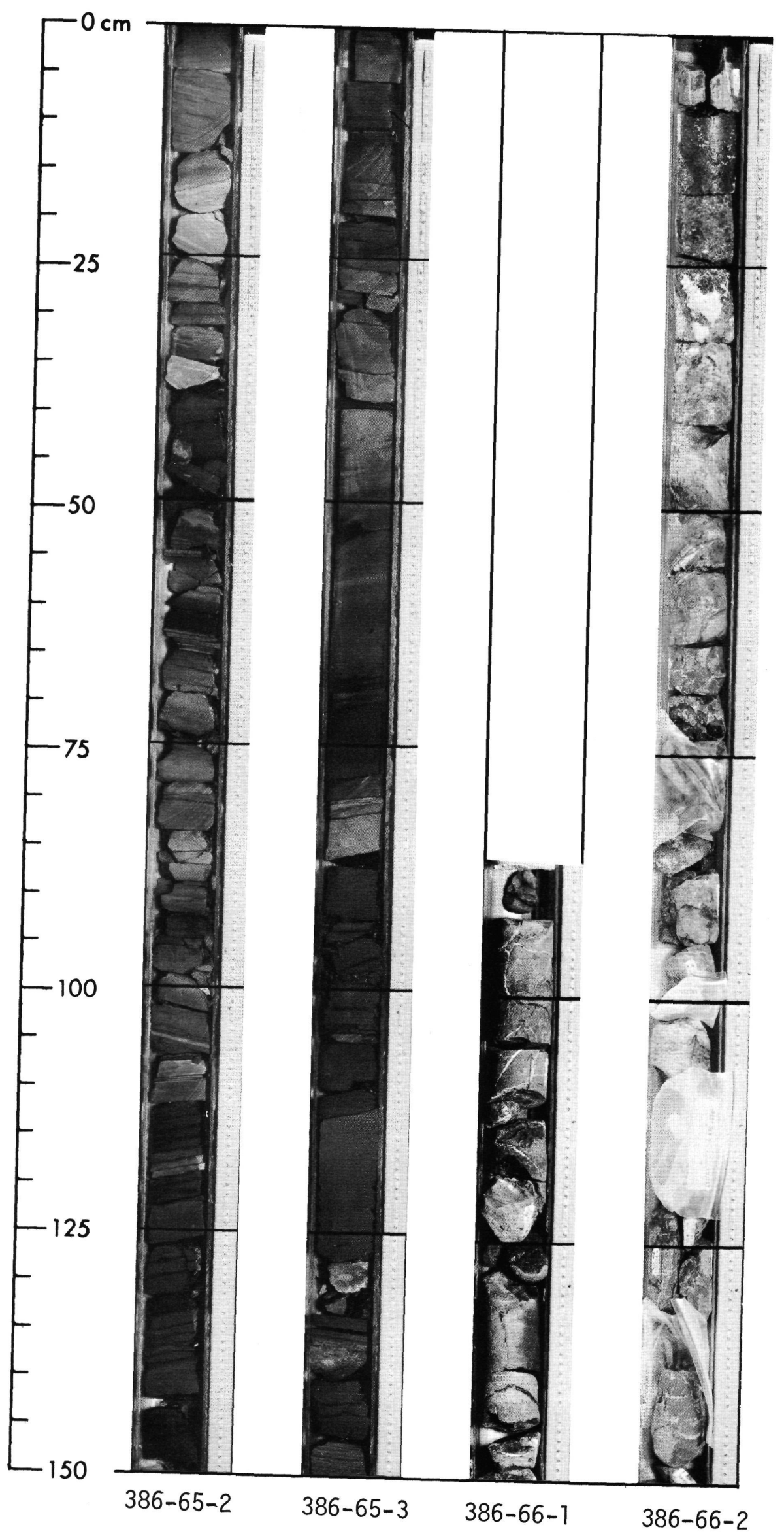

